University of Nebraska - Lincoln

DigitalCommons@University of Nebraska - Lincoln

2000

\title{
Metals Transport in the Sacramento River, California, 1996-1997 Volume 2: Interpretation of Metal Loads
}

Charles N. Alpers

U.S. Geological Survey

Ronald C. Antweiler

U.S. Geological Survey

Howard E. Taylor

U.S. Geological Survey, hetaylor@usgs.gov

Peter D. Dileanis

U.S. Geological Survey

Joseph L. Domagalski

U.S. Geological Survey, joed@usgs.gov

Follow this and additional works at: https://digitalcommons.unl.edu/usgspubs

Part of the Earth Sciences Commons

Alpers, Charles N.; Antweiler, Ronald C.; Taylor, Howard E.; Dileanis, Peter D.; and Domagalski, Joseph L., "Metals Transport in the Sacramento River, California, 1996-1997 Volume 2: Interpretation of Metal Loads" (2000). Publications of the US Geological Survey. 49.

https://digitalcommons.unl.edu/usgspubs/49

This Article is brought to you for free and open access by the US Geological Survey at DigitalCommons@University of Nebraska - Lincoln. It has been accepted for inclusion in Publications of the US Geological Survey by an authorized administrator of DigitalCommons@University of Nebraska - Lincoln. 


\section{Metals Transport in the Sacramento River, California, 1996-1997 \\ Volume 2: Interpretation of Metal Loads}

U.S. Department of the Interior

U.S. Geological Survey

Prepared in cooperation with the

Sacramento Regional County Sanitation District

California State Water Resources Control Board

U.S. Environmental Protection Agency

U.S. Department of Commerce, National Marine Fisheries Service

\section{Water-Resources Investigations Report 00-4002}

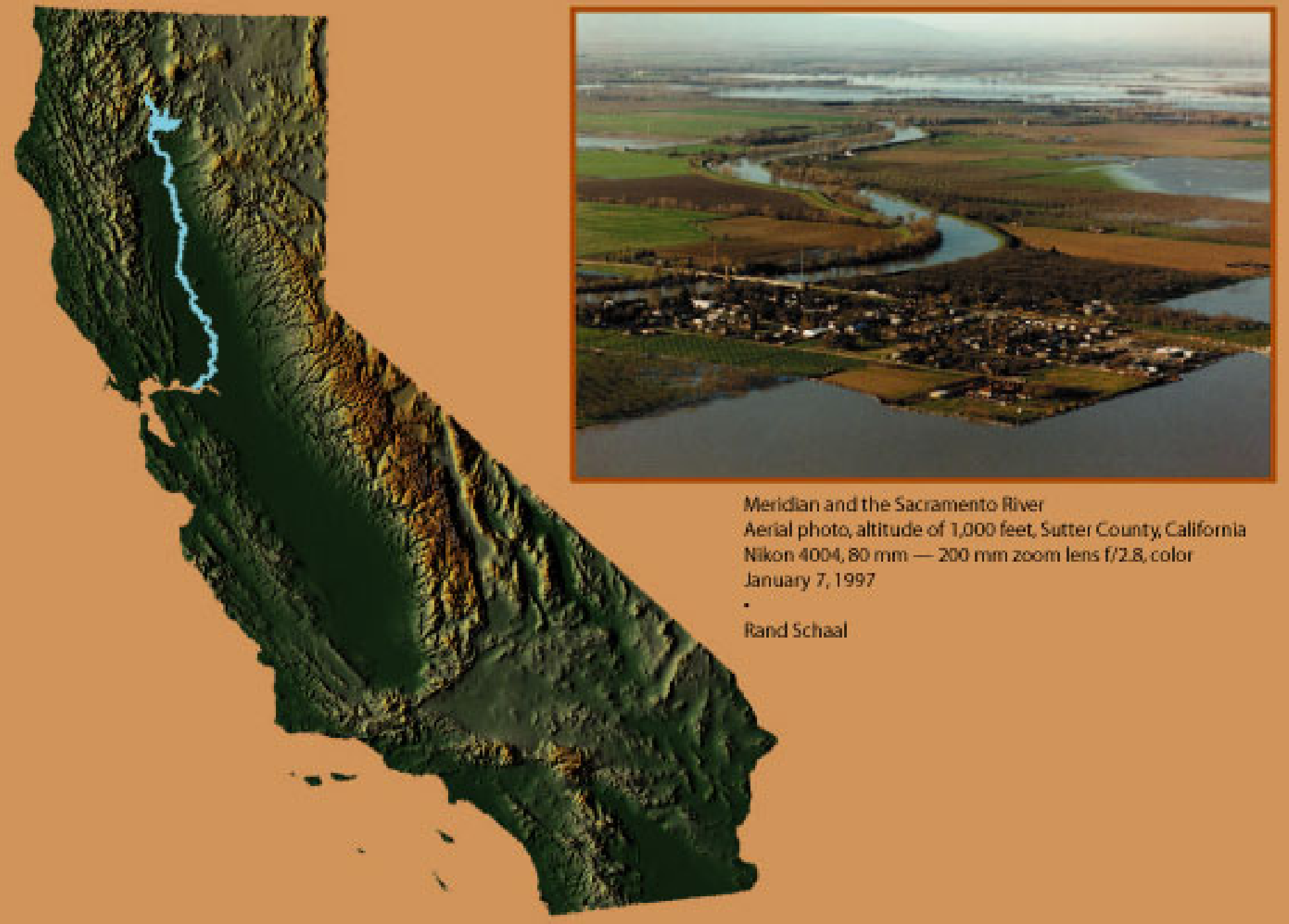


Meridian and the Sacramento River

Aerial photo, altitude of 1,000 feet, Sutter County, California

Nikon 4004, $80 \mathrm{~mm}-200 \mathrm{~mm}$ zoom lens f/2.8, color

January 7, 1997 C Rand Schaal 


\section{Metals Transport in the Sacramento River, California, 1996-1997}

\section{Volume 2: Interpretation of Metal Loads}

Charles N. Alpers, Ronald C. Antweiler, Howard E. Taylor, Peter D. Dileanis, and Joseph L. Domagalski

U.S. GEOLOGICAL SURVEY

Water-Resources Investigations Report 00-4002

In cooperation with

Sacramento Regional County Sanitation District California State Water Resources Control Board

U.S. Environmental Protection Agency

U.S. Department of Commerce, National Marine Fisheries Service 


\title{
U.S. DEPARTMENT OF THE INTERIOR BRUCE BABBITT, Secretary
}

\author{
U.S. GEOLOGICAL SURVEY
}

Charles G. Groat, Director

The use of firm, trade, and brand names in this report is for identification purposes only and does not constitute endorsement by the U.S. Geological Survey

For additional information write to:

District Chief

U.S. Geological Survey

Water Resources Division

Placer Hall

$6000 \mathrm{~J}$ Street

Sacramento, California 95819-6129
Copies of this report can be purchased from:

U.S. Geological Survey

Branch of Information Services

Box 25286

Denver, CO 80225-0286 


\section{FOREWORD}

The U.S. Geological Survey (USGS) is committed to serve the Nation with accurate and timely scientific information that helps enhance and protect the overall quality of life, and facilitates effective management of water, biological, energy, and mineral resources. (http://www.usgs.gov/). Information on the quality of the Nation's water resources is of critical interest to the USGS because it is so integrally linked to the long-term availability of water that is clean and safe for drinking and recreation and that is suitable for industry, irrigation, and habitat for fish and wildlife. Escalating population growth and increasing demands for the multiple water uses make water availability, now measured in terms of quantity and quality, even more critical to the long-term sustainability of our communities and ecosystems.

The USGS implemented the National Water-Quality Assessment (NAWQA) Program to support national, regional, and local information needs and decisions related to water-quality management and policy. (http:// water.usgs.gov/nawqa). Shaped by and coordinated with ongoing efforts of other Federal, State, and local agencies, the NAWQA Program is designed to answer: What is the condition of our Nation's streams and ground water? How are the conditions changing over time? How do natural features and human activities affect the quality of streams and ground water, and where are those effects most pronounced? By combining information on water chemistry, physical characteristics, stream habitat, and aquatic life, the NAWQA Program aims to provide science-based insights for current and emerging water issues and priorities.

NAWQA results can contribute to informed decisions that result in practical and effective water-resource management and strategies that protect and restore water quality.

Since 1991, the NAWQA Program has implemented interdisciplinary assessments in more than 50 of the Nation's most important river basins and aquifers, referred to as Study Units. (http://water.usgs.gov/nawqa/ nawqamap.html). Collectively, these Study Units account for more than 60 percent of the overall water use and population served by public water supply, and are representative of the Nation's major hydrologic landscapes, priority ecological resources, and agricultural, urban, and natural sources of contamination.

Each assessment is guided by a nationally consistent study design and methods of sampling and analysis. The assessments thereby build local knowledge about waterquality issues and trends in a particular stream or aquifer while providing an understanding of how and why water quality varies regionally and nationally. The consistent, multi-scale approach helps to determine if certain types of water-quality issues are isolated or pervasive, and allows direct comparisons of how human activities and natural processes affect water quality and ecological health in the Nation's diverse geographic and environmental settings. Comprehensive assessments on pesticides, nutrients, volatile organic compounds, trace metals, and aquatic ecology are developed at the national scale through comparative analysis of the Study-Unit findings. (http://water.usgs.gov/ nawqa/natsyn.html).

The USGS places high value on the communication and dissemination of credible, timely, and relevant science so that the most recent and available knowledge about water resources can be applied in management and policy decisions. We hope this NAWQA publication will provide you the needed insights and information to meet your needs, and thereby foster increased awareness and involvement in the protection and restoration of our Nation's waters.

The NAWQA Program recognizes that a national assessment by a single program cannot address all waterresource issues of interest. External coordination at all levels is critical for a fully integrated understanding of watersheds and for cost-effective management, regulation, and conservation of our Nation's water resources. The Program, therefore, depends extensively on the advice, cooperation, and information from other Federal, State, interstate, Tribal, and local agencies, non-government organizations, industry, academia, and other stakeholder groups. The assistance and suggestions of all are greatly appreciated.

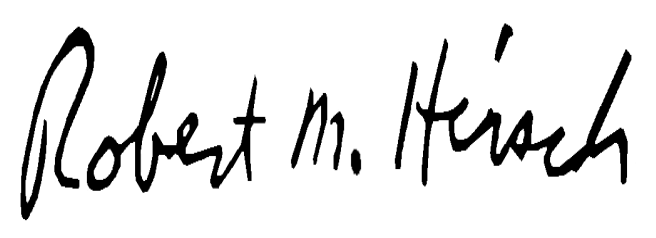

Robert M. Hirsch

Associate Director for Water 


\section{CONTENTS}

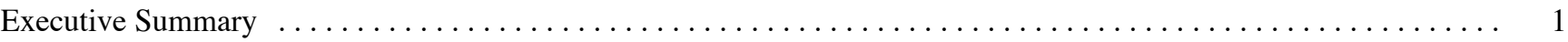

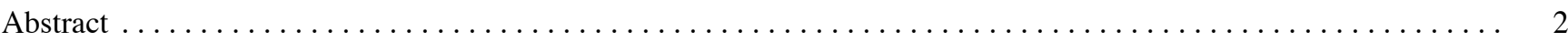

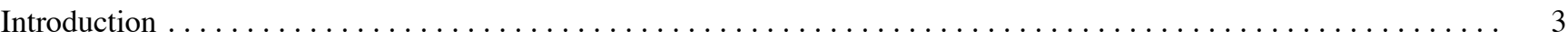

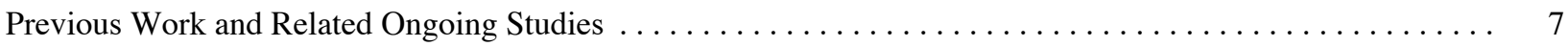

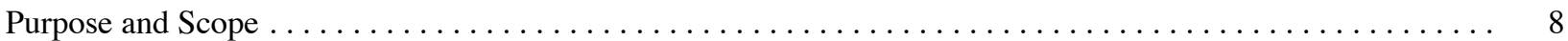

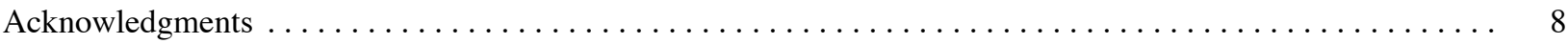

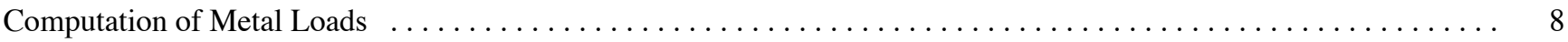

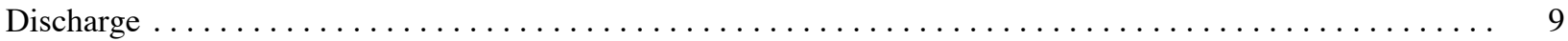

Dissolved Loads $\ldots \ldots \ldots \ldots \ldots \ldots \ldots \ldots \ldots \ldots \ldots \ldots \ldots \ldots \ldots \ldots$

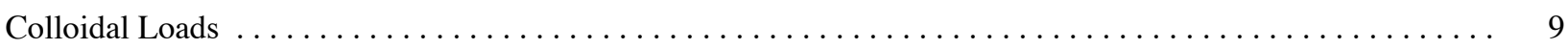

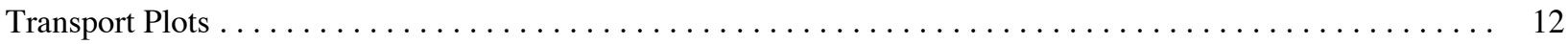

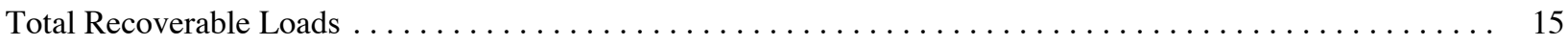

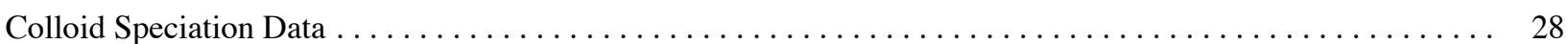

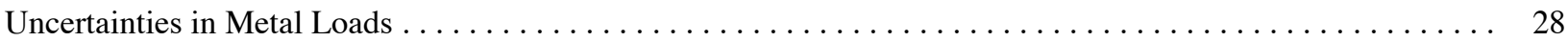

Discussion of Spatial and Temporal Variations in Metal Loads . . . . . . . . . . . . . . . . . . . . . 29

Temporal Variations in Dissolved and Colloidal Loads $\ldots \ldots \ldots \ldots \ldots \ldots$

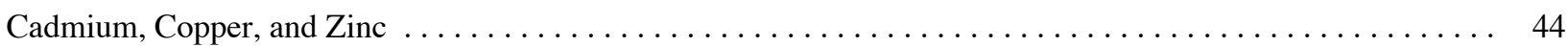

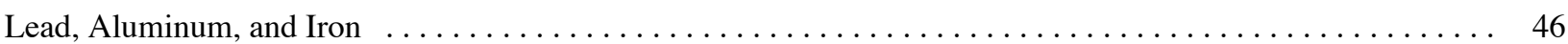

Discussion of Transport and Fate of Metals from Various Sources $\ldots \ldots \ldots \ldots \ldots \ldots$

Copper-Zinc-Lead Mines in the Shasta Region $\ldots \ldots \ldots \ldots \ldots \ldots$

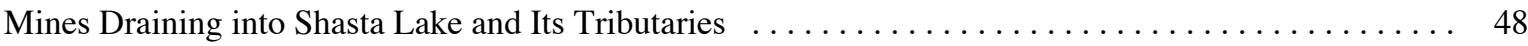

Mines Draining into Keswick Reservoir and Its Tributaries . . . . . . . . . . . . . . . . . 49

Mass Balance and Metal Transport in Keswick Reservoir $\ldots \ldots \ldots \ldots \ldots \ldots \ldots$

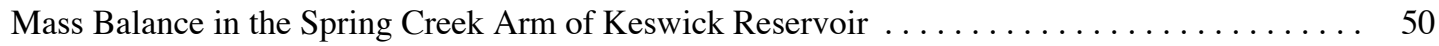

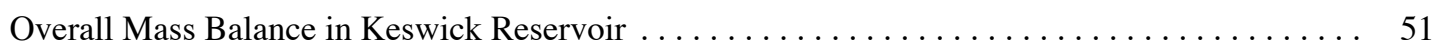

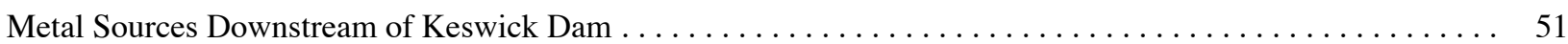

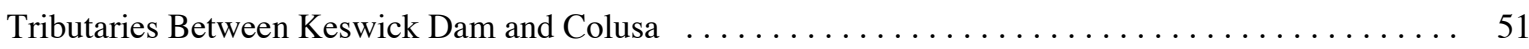

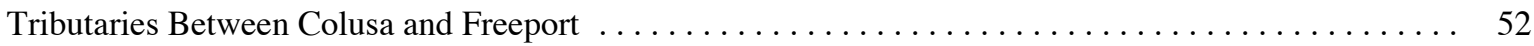

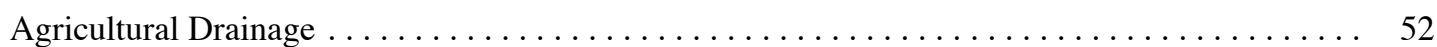

Urban Runoff $\ldots \ldots \ldots \ldots \ldots \ldots \ldots \ldots \ldots \ldots \ldots \ldots \ldots \ldots \ldots \ldots \ldots \ldots \ldots \ldots$

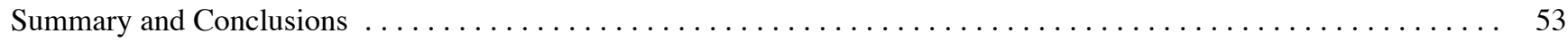

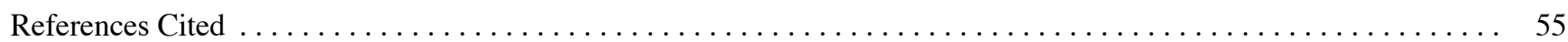

Appendix 1. Tables of Data Comparing Metal Loads in Dissolved Form, Colloidal Form, and Whole Water. . . . . . . 57

Appendix 2. Tables of Data Comparing Metal Loads Relative to Loads at Freeport and in the Yolo Bypass. . . . . . . . 73

Appendix 3. Tables of Data Comparing Metal Loads Used in Mass Balance Calculations for the

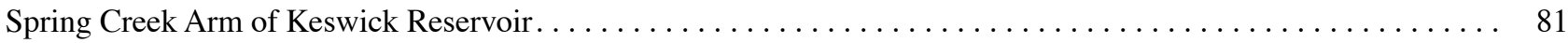

Appendix 4. Tables of Data Comparing Metal Loads Used in Mass Balance Calculations

for Keswick Reservoir . . . . . . . . . . . . . . . . . . . . . . . . . . . . . 89

Appendix 5. Plots of Metal Loads in Dissolved and Colloidal Forms for Miscellaneous Trace Metals in Water . . . . . 97

Appendix 6. Hydrographs Showing Daily Mean Discharge and Time of Sampling . . . . . . . . . . . . . . . 103 


\section{FIGURES}

1. Location map of Sacramento River watershed, California $\ldots \ldots \ldots \ldots \ldots \ldots \ldots \ldots \ldots \ldots \ldots \ldots$

2. Location map of West Shasta mining district, Shasta County, California $\ldots \ldots \ldots \ldots \ldots \ldots \ldots \ldots \ldots$

3A. Diagram showing magnitude of mean discharge in the Sacramento River, California, relative to major tributaries and diversions during the July 11-18, 1996 sampling period $\ldots \ldots \ldots \ldots \ldots \ldots \ldots$

3B. Diagram showing magnitude of mean discharge in the Sacramento River, California, relative to major tributaries and diversions during the September 18-26, 1996sampling period $\ldots \ldots \ldots \ldots \ldots \ldots$

3C. Diagram showing magnitude of mean discharge in the Sacramento River, California, relative to major tributaries and diversions during the November 12-22, 1996 sampling period $\ldots \ldots \ldots \ldots \ldots \ldots$

$3 D$. Diagram showing magnitude of mean discharge in the Sacramento River, California, relative to major tributaries and diversions during the December 11-18, 1996 sampling period

$3 E$. Diagrams showing magnitude of mean discharge in the Sacramento River, California, relative to major tributaries and diversions during the January $2-8,1997$ sampling period $\ldots \ldots \ldots \ldots \ldots \ldots \ldots$

$3 F$. Diagrams showing magnitude of mean discharge in the Sacramento River, California, relative to major tributaries and diversions during the May 28-June 6, 1997 sampling period (1)

Plot of dissolved and colloidal aluminum loads, July 1996 to May-June 1997, Sacramento River,

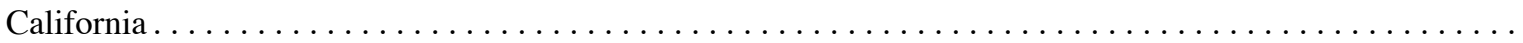

5. Plot of dissolved and colloidal cadmium loads, July 1996 to May-June 1997, Sacramento River,

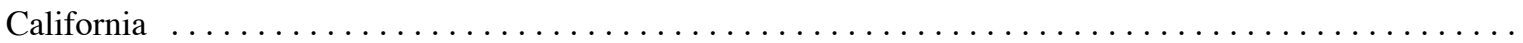

6. Plot of dissolved and colloidal copper loads, July 1996 to May-June 1997, Sacramento River,

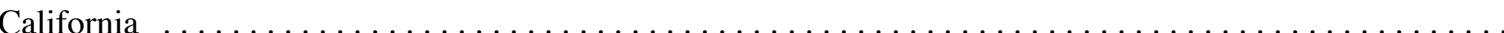

7. Plot of dissolved and colloidal iron loads, July 1996 to May-June 1997, Sacramento River,

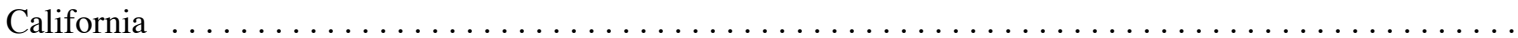

8. Plot of dissolved and colloidal lead loads, July 1996 to May-June 1997, Sacramento River,

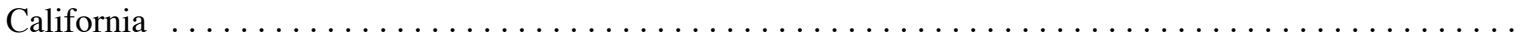

9. Plot of dissolved and colloidal zinc loads, July 1996 to May-June 1997, Sacramento River, California . . . . .

10. Plots of dissolved and colloidal aluminum loads, colloid concentration, aluminum concentration in colloids, and discharge, Sacramento River, California for A. July 1996, B. September 1996, C. November 1996,

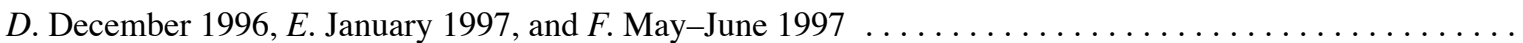

11. Plots of dissolved and colloidal cadmium loads, colloid concentration, cadmium concentration in colloids, and discharge, Sacramento River, California for A. July 1996, B. September 1996, C. November 1996, $D$. December 1996, E. January 1997, and $F$. May-June 1997 . . . . . . . . . . . . . . . . . . . . . . . . .

12. Plots of dissolved and colloidal copper loads, colloid concentration, copper concentration in colloids, and discharge, Sacramento River, California for A. July 1996, B. September 1996, C. November 1996,

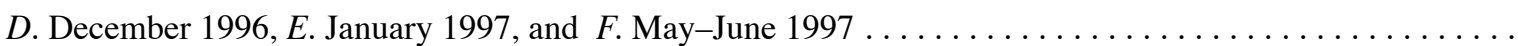

13. Plots of dissolved and colloidal iron loads, colloid concentration, iron concentration in colloids, and discharge, Sacramento River, California for A. July 1996, B. September 1996, C. November 1996, $D$. December 1996, E. January 1997, and F. May-June 1997

14. Plots of dissolved and colloidal lead loads, colloid concentration, lead concentrations in colloids, and discharge, Sacramento River, California for A. July 1996, B. September 1996, C. November 1996, $D$. December 1996, E. January 1997, and F. May-June 1997

15. Plots of dissolved and colloidal zinc loads, colloid concentration, zinc concentrations in colloids, and discharge, Sacramento River, California for A. July 1996, B. September 1996, C. November 1996, $D$. December 1996, E. January 1997, and F. May-June 1997 
16A. Distribution and speciation of colloidal cadmium loads during December 1996, Sacramento River,

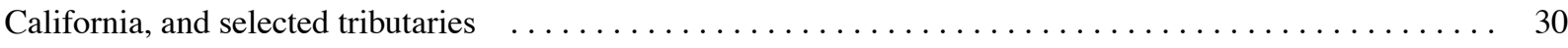

16B. Distribution and speciation of colloidal copper loads during December 1996, Sacramento River,

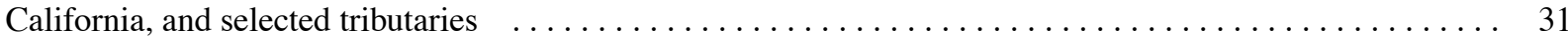

16C. Distribution and speciation of colloidal lead loads during December 1996, Sacramento River,

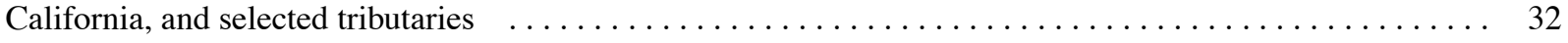

16D. Distribution and speciation of colloidal zinc loads during December 1996, Sacramento River,

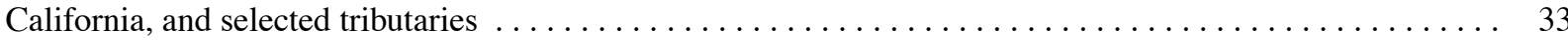

17A. Distribution and speciation of colloidal cadmium loads during January 1997, Sacramento River,

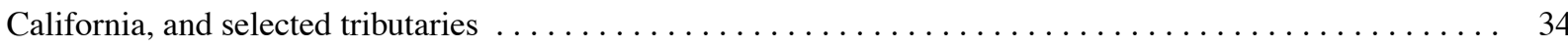

17B. Distribution and speciation of colloidal copper loads during January 1997, Sacramento River,

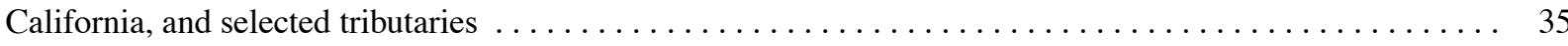

17C. Distribution and speciation of colloidal lead loads during January 1997, Sacramento River,

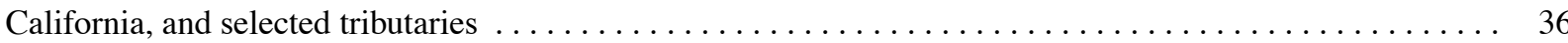

17D. Distribution and speciation of colloidal zinc loads during January 1997, Sacramento River,

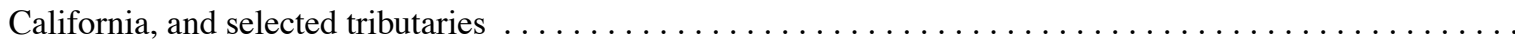

18A. Distribution and speciation of colloidal cadmium loads during May-June 1997, Sacramento River,

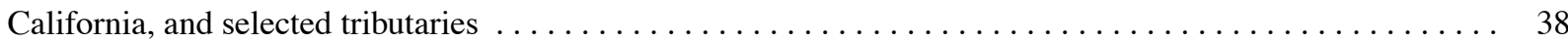

18B. Distribution and speciation of colloidal copper loads during May-June 1997, Sacramento River,

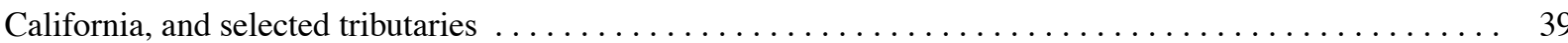

18C. Distribution and speciation of colloidal lead loads during May-June 1997, Sacramento River,

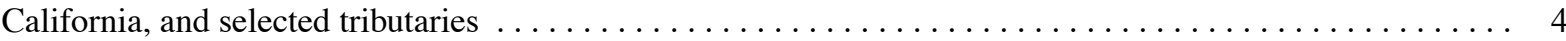

18D. Distribution and speciation of colloidal zinc loads during May-June 1997, Sacramento River,

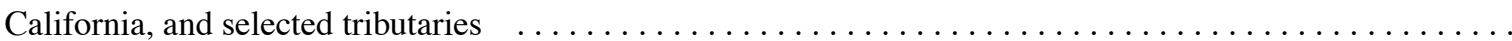

19. Plots of suspended sediment concentration $(A)$ and load $(B)$ versus stream flow at Freeport,

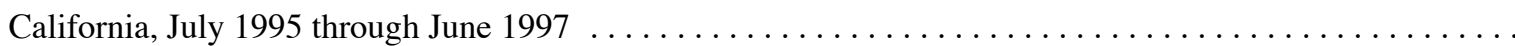

20. Graph showing elevation of streambed in relation to distance from river mouth, Keswick Dam

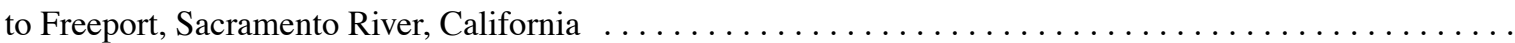

21. Probability box illustrations showing distribution of $(A) \mathrm{Zn} / \mathrm{Cd}$ and $(B) \mathrm{Zn} / \mathrm{Cu}$ data in dissolved and colloidal samples taken July 1996 through June 1997, Sacramento River, California . . . . . . . . . . . . .

Appendix 5. Plots of metal loads in dissolved and colloidal forms for miscellaneous trace metals in water

A5-1. Plot of dissolved and colloidal chromium loads, July 1996 to May-June 1997, Sacramento River,

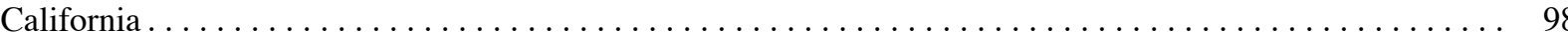

A5-2. Plot of dissolved and colloidal cobalt loads, July 1996 to May-June 1997, Sacramento River, California . . . 99

A5-3. Plot of dissolved and colloidal nickel loads, July 1996 to May-June 1997, Sacramento River, California . . . 100

A5-4. Plot of dissolved and colloidal yttrium loads, July 1996 to May-June 1997, Sacramento River, California . . 101

Appendix 6. Hydrographs showing daily mean discharge and time of sampling

A6-1. Hydrographs showing daily mean discharge and time of sampling, November 1996, Sacramento River, California for $A$. Below Keswick Dam, $B$. Bend Bridge, $C$. Colusa, $D$. Yolo Bypass,

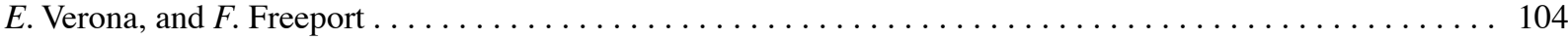

A6-2. Hydrographs showing daily mean discharge and time of sampling, December 1996, Sacramento River,

California for $A$. Below Keswick Dam, B. Bend Bridge, $C$. Colusa, D. Yolo Bypass,

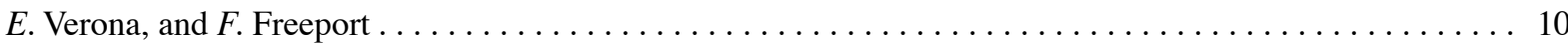

Contents vii 
A6-3. Hydrographs showing daily mean discharge and time of sampling, January 1997, Sacramento River,

California for A. Below Keswick Dam, B. Bend Bridge, C. Colusa, D. Yolo Bypass,

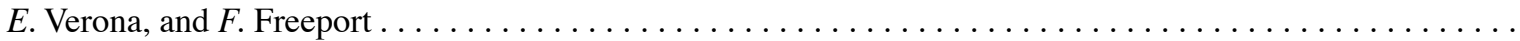

\section{TABLES}

Appendix 1. Tables of Data Comparing Metal Loads in Dissolved Form, Colloidal Form, and Whole Water

A1-1. Aluminum loads derived from concentrations in dissolved, colloid, and whole water samples . . . . 58

A1-2. Cadmium loads derived from concentrations in dissolved, colloid, and whole water samples. . . . . . 60

A1-3. Copper loads derived from concentrations in dissolved, colloid, and whole water samples......... 62

A1-4. Iron loads derived from concentrations in dissolved, colloid, and whole water samples . . . . . . . . . 64

A1-5. Lead loads derived from concentrations in dissolved, colloid, and whole water samples . ....... 66

A1-6. Mercury loads derived from concentrations in dissolved, colloid, and whole water samples........ 68

A1-7. Zinc loads derived from concentrations in dissolved, colloid, and whole water samples ......... 70

Appendix 2. Tables of Data Comparing Metal Loads Relative to Loads at Freeport and in the Yolo Bypass

A2-1. Aluminum loads divided by sum of loads at Freeport and in Yolo Bypass, derived from concentrations in dissolved, colloid, and whole water samples $\ldots \ldots \ldots \ldots \ldots \ldots \ldots \ldots \ldots \ldots$

A2-2. Cadmium loads divided by sum of loads at Freeport and in Yolo Bypass, derived from concentrations in dissolved, colloid, and whole water samples $\ldots \ldots \ldots \ldots \ldots \ldots \ldots \ldots \ldots \ldots \ldots \ldots$

A2-3. Copper loads divided by sum of loads at Freeport and in Yolo Bypass, derived from concentrations in dissolved, colloid, and whole water samples $\ldots \ldots \ldots \ldots \ldots \ldots \ldots \ldots \ldots \ldots$

A2-4. Iron loads divided by sum of loads at Freeport and in Yolo Bypass, derived from concentrations in dissolved, colloid, and whole water samples $\ldots \ldots \ldots \ldots \ldots \ldots \ldots \ldots \ldots \ldots \ldots$

A2-5. Lead loads divided by sum of loads at Freeport and in Yolo Bypass, derived from concentrations in dissolved, colloid, and whole water samples $\ldots \ldots \ldots \ldots \ldots \ldots \ldots \ldots \ldots \ldots$

A2-6. Mercury loads divided by sum of loads at Freeport and in Yolo Bypass, derived from concentrations in dissolved, colloid, and whole water samples

A2-7. Zinc loads divided by sum of loads at Freeport and in Yolo Bypass, derived from concentrations in dissolved, colloid, and whole water samples ...

Appendix 3. Tables of Data Comparing Metal Loads Used in Mass Balance Calculations for the Spring Creek arm

of Keswick Reservoir

A3-1. Aluminum loads derived from concentrations in dissolved, colloid, and whole water samples used in mass balance calculations for the Spring Creek arm of Keswick Reservoir. . . . . . . . . . .

A3-2. Cadmium loads derived from concentrations in dissolved, colloid, and whole water samples used in mass balance calculations for the Spring Creek arm of Keswick Reservoir..............

A3-3. Copper loads derived from concentrations in dissolved, colloid, and whole water samples used in mass balance calculations for the Spring Creek arm of Keswick Reservoir . . . . . . . . . . . . .

A3-4. Iron loads derived from concentrations in dissolved, colloid, and whole water samples used in mass balance calculations for the Spring Creek arm of Keswick Reservoir . . . . . . . . . . . . .

A3-5. Lead loads derived from concentrations in dissolved, colloid, and whole water samples used in mass balance calculations for the Spring Creek arm of Keswick Reservoir . . . . . . . . . . . . .

A3-6. Mercury loads derived from concentrations in dissolved, colloid, and whole water samples used in mass balance calculations for the Spring Creek arm of Keswick Reservoir. . . . . . . . . . .

A3-7. Zinc loads derived from concentrations in dissolved, colloid, and whole water samples used in mass balance calculations for the Spring Creek arm of Keswick Reservoir 
Appendix 4. Tables of Data Comparing Metal Loads Used in Mass Balance Calculations for Keswick Reservoir

A4-1. Aluminum loads derived from concentrations in dissolved, colloid, and whole water samples used in mass balance calculations for Keswick Reservoir . . . . . . . . . . . . . . . . . . . . .

A4-2. Cadmium loads derived from concentrations in dissolved, colloid, and whole water samples used in mass balance calculations forKeswick Reservoir $\ldots \ldots \ldots \ldots \ldots \ldots \ldots \ldots \ldots \ldots \ldots \ldots \ldots \ldots$

A4-3. Copper loads derived from concentrations in dissolved, colloid, and whole water samples used in mass balance calculations for Keswick Reservoir. . . . . . . . . . . . . . . . . . . . . . . . . . . . .

A4-4. Iron loads derived from concentrations in dissolved, colloid, and whole water samples used in mass balance calculations for Keswick Reservoir . . . . . . . . . . . . . . . . . . . . . . .

A4-5. Lead loads derived from concentrations in dissolved, colloid, and whole water samples used in mass balance calculations for Keswick Reservoir. . . . . . . . . . . . . . . . . . . . . . . . . . .

A4-6. Mercury loads derived from concentrations in dissolved, colloid, and whole water samples used in mass balance calculations for Keswick Reservoir. . . . . . . . . . . . . . . . . . . . . .

A4-7. Zinc loads derived from concentrations in dissolved, colloid, and whole water samples used in mass balance calculations for Keswick Reservoir. 


\section{CONVERSION FACTORS, VERTICAL DATUM, ACRONYMS and ABBREVIATIONS, and CHEMICAL ELEMENTS}

\begin{tabular}{rcl}
\multicolumn{1}{c}{ Conversion Factors } & & \\
\hline Multiply & By & \multicolumn{1}{c}{ To obtain } \\
\hline acre-foot $($ acre-ft) & 1,233 & kiloliter \\
cubic foot per second $\left(\mathrm{ft}^{3} / \mathrm{s}\right)$ & 0.02832 & cubic meter per second \\
cubic foot per second $\left(\mathrm{ft}^{3} / \mathrm{s}\right)$ & 28.32 & liter per second \\
cubic yard $\left(\mathrm{yd}^{3}\right)$ & 0.7646 & cubic meter \\
foot $(\mathrm{ft})$ & 0.3048 & meter \\
mile $(\mathrm{mi})$ & 1.609 & kilometer \\
pound $^{2}$ & 0.4536 & kilogram \\
square mile (mi $\left.{ }^{2}\right)$ & 2.590 & square kilometer \\
short ton & 0.9072 & megagram (metric ton)
\end{tabular}

Temperature is given in degrees Celsius $\left({ }^{\circ} \mathrm{C}\right)$, which can be converted to degrees Fahrenheit $\left({ }^{\circ} \mathrm{F}\right)$ by the following equation:

$$
{ }^{\circ} \mathrm{F}=1.8\left({ }^{\circ} \mathrm{C}\right)+32 .
$$

\section{Vertical Datum}

Sea level: In this paper, "sea level" refers to the National Geodetic Vertical Datum of 1929-a geodetic datum derived from a general adjustment of the first-order level nets of the United States and Canada, formerly called Sea Level Datum of 1929.

\section{Acronyms and Abbreviations}

(Additional information given in parentheses)

$\mu \mathrm{g}$, microgram

$\mu \mathrm{g} / \mathrm{L}$, microgram per liter

$\mu \mathrm{m}$, micrometer

$\mathrm{kg} / \mathrm{d}$, kilogram per day

$\mathrm{km}$, kilometer

L, liter

$\mathrm{m}^{3} / \mathrm{s}$, cubic meter per second

$\mathrm{mL}$, milliliter

$\mathrm{mm}$, millimeter

ng, nanogram

$\mathrm{ng} / \mathrm{L}$, nanogram per liter

$\mathrm{nm}$, nanometer

Br., Bridge

CMP, Coordinated Monitoring Program

CVP, Central Valley Project

EPA, U.S. Environmental Protection Agency

MOU, Memorandum of Understanding

NAWQA, National Water-Quality Assessment (Program) 
NMWL, Nominal Molecular Weight Limit

NWQL, National Water Quality Laboratory

ROD, Record of Decision

SCDD, Spring Creek Debris Dam

SCPP, Spring Creek Power Plant

SRM, standard reference material

USGS, U.S. Geological Survey

\section{Elements and Compounds}

\section{Elements}
$\mathrm{Al}$, aluminum
$\mathrm{Cd}$, cadmium
Co, cobalt
$\mathrm{Cr}$, chromium
$\mathrm{Cu}$, copper
$\mathrm{Fe}$, iron
$\mathrm{Hg}$, mercury
$\mathrm{Ni}$, nickel
$\mathrm{Pb}$, lead
$\mathrm{Y}$, yttrium
$\mathrm{Zn}$, zinc

\section{Compounds}

$\mathrm{HCl}$, hydrochloric acid

HF, hydrofluoric acid

$\mathrm{HNO}_{3}$, nitric acid 


\title{
Metals Transport in the Sacramento River, California, 1996-1997: Volume 2. Interpretation of Metal Loads
}

\author{
Charles N. Alpers, Ronald C. Antweiler, Howard E. Taylor, Peter D. Dileanis, and \\ Joseph L. Domagalski
}

\section{Executive Summary}

Transport of metals in the Sacramento River from Shasta Dam to Freeport was evaluated for the period July 1996 through June 1997 using an approach that quantified the dissolved and colloidal concentrations and corresponding loads of metals at six mainstem sites during six sampling periods. Two of the sampling periods (December 1996 and January 1997) took place during relatively high-flow conditions, whereas the other four sampling periods (July, September, and November 1996 and May-June 1997) took place during lower flow conditions. The water year corresponding to the duration of this study was unusual for northern California in that precipitation was concentrated primarily in December and January with an extremely dry period from February to April. The overall precipitation for the year was close to long-term averages; however, severe flooding took place in early January 1997 at several locations in the Sacramento River watershed. Approximately 70 percent of total annual discharge at the two farthest downstream sampling locations (Sacramento River at Freeport and Yolo Bypass at Interstate 80) took place during the 3-month period December 1996 through February 1997. Because of increased transport of suspended sediment and higher total metal concentrations in water during this wet period, the proportion of annual metal loads transported was significantly greater than 70 percent.

The proportions of cadmium, copper, lead, and zinc loads that are exported from the Sacramento River to the San Francisco Bay and the Sacramento-San Joaquin Delta estuary (hereinafter referred to as the Bay-Delta), and that are associated with the mineralized areas upstream of Keswick Dam, were estimated by comparing metal loads at Keswick Dam with those at the site(s) sampled farthest downstream, generally the Sacramento River at Freeport (and the Yolo Bypass, when flowing). The results are highly dependent on the flow regime. The following proportions of mineralization-related trace-metal loads were observed (percentages represent dissolved plus colloidal loads at Keswick Dam divided by the sum of dissolved and colloidal loads at Freeport and the Yolo Bypass). During moderately high flows in December 1996, percentages were cadmium, 87 percent; copper, 35 percent; lead, 10 percent; and zinc, 51 percent. During flood conditions in early January 1997, percentages were cadmium, 22 percent; copper, 11 percent; lead, 2 percent; and zinc, 15 percent. During irrigation drainage season from rice fields during May-June 1997, percentages were cadmium, 53 percent; copper, 42 percent; lead, 20 percent; and zinc, 75 percent. These estimates must be qualified by the following factors. First, metal loads at Colusa in December 1996 and at Verona during May-June 1997 generally exceeded those determined at Freeport during those sampling periods. Therefore, the above percentages represent maximum estimates of the apparent total proportion of metals from mineralized areas upstream of Keswick Dam. Second, the Sacramento River was sampled at Tower Bridge 
instead of at Freeport during January 1997 for logistics reasons.

Available data suggest that trace-metal loads from agricultural drainage may be significant during certain flow conditions. However, additional studies are needed before definitive conclusions can be drawn. Load data for sampling periods during July and September 1996 and during May-June 1997 show increases of dissolved and colloidal copper and colloidal zinc between Colusa and Verona, the reach of the Sacramento River along which the Colusa Basin Drain, the Sacramento Slough, and other agricultural return flows are tributaries. Monthly sampling of these two agricultural drains by the U.S. Geological Survey's National Water-Quality Assessment Program shows seasonal variations in metal concentrations. For example, "dissolved" (0.45-micrometer filtrate) copper concentrations in National Water-Quality Assessment Program samples from the Colusa Basin Drain reached 6 micrograms per liter in May 1996 and 3 to 4 micrograms per liter in June 1997; "dissolved" copper in the Sacramento Slough reached a maximum of 4 micrograms per liter in December 1996. To put the copper loads associated with agricultural drainage in perspective, the total (dissolved plus colloidal) load of copper from the Colusa Basin Drain in June 1997 was 18 kilograms per day, whereas the copper load in Spring Creek, which drains the inactive mines on Iron Mountain, was 20 kilograms per day during the same sampling period. In contrast, during the January 1997 flood, the copper load in Spring Creek was about 1,100 kilograms per day and the copper load in the Yolo Bypass was about 7,300 kilograms per day. These data clearly indicate that the majority of copper and zinc loads during the January 1997 flood entered the Sacramento River upstream of Colusa and upstream of the influence of most intense agricultural drainage return flows in the Sacramento River Watershed.

This study has demonstrated that some trace metals of environmental significance (cadmium, copper, and zinc) in the Sacramento River are transported largely in dissolved form at upstream sites (below Shasta Dam, below
Keswick Dam, and at Bend Bridge) proximal to the mineralized areas of the West Shasta and East Shasta mining districts. In the acidic water of Spring Creek, cadmium, copper, and zinc are transported almost exclusively in dissolved form. In contrast, these trace metals are transported largely in colloidal form at downstream sites (Colusa, Verona, Freeport, and Yolo Bypass). Aluminum, iron, and lead were observed to be transported predominantly in the colloidal phase at all mainstem Sacramento River sampling sites during all sampling periods in this study. Despite continuous water treatment that has removed 85 to 90 percent of the cadmium, copper, and zinc from the mine drainage at Iron Mountain, Spring Creek remains an important source of these metals to the Sacramento River system.

\section{Abstract}

Metals transport in the Sacramento River, northern California, from July 1996 to June 1997 was evaluated in terms of metal loads from samples of water and suspended colloids that were collected on up to six occasions at 13 sites in the Sacramento River Basin. Four of the sampling periods (July, September, and November 1996; and May-June 1997) took place during relatively low-flow conditions and two sampling periods (December 1996 and January 1997) took place during high-flow and flooding conditions, respectively. This study focused primarily on loads of cadmium, copper, lead, and zinc, with secondary emphasis on loads of aluminum, iron, and mercury.

Trace metals in acid mine drainage from abandoned and inactive base-metal mines, in the East and West Shasta mining districts, enter the Sacramento River system in predominantly dissolved form into both Shasta Lake and Keswick Reservoir. The proportion of trace metals that was dissolved (as opposed to colloidal) in samples collected at Shasta and Keswick dams decreased in the order zinc $\approx$ cadmium $>$ copper $>$ lead. At four sampling sites on the Sacramento River-71, 256,360 , and 412 kilometers downstream of 
Keswick Dam - trace-metal loads were predominantly colloidal during both high- and low-flow conditions. The proportion of total cadmium, copper, lead, and zinc loads transported to San Francisco Bay and the Sacramento-San Joaquin Delta estuary (referred to as the Bay-Delta) that is associated with mineralized areas was estimated by dividing loads at Keswick Dam by loads 412 kilometers downstream at Freeport and the Yolo Bypass. During moderately high flows in December 1996, mineralization-related total (dissolved + colloidal) trace-metal loads to the Bay-Delta (as a percentage of total loads measured downstream) were cadmium, 87 percent; copper, 35 percent; lead, 10 percent; and zinc, 51 percent. During flood conditions in January 1997 loads were cadmium, 22 percent; copper, 11 percent; lead, 2 percent; and zinc, 15 percent. During irrigation drainage season from rice fields (May-June 1997) loads were cadmium, 53 percent; copper, 42 percent; lead, 20 percent; and zinc, 75 percent. These estimates must be qualified by the following factors: (1) metal loads at Colusa in December 1996 and at Verona in May-June 1997 generally exceeded those determined at Freeport during those sampling periods. Therefore, the above percentages represent maximum estimates of the apparent total proportion of metals from mineralized areas upstream of Keswick Dam; and (2) for logistics reasons, the Sacramento River was sampled at Tower Bridge instead of at Freeport during January 1997.

Available data suggest that trace metal loads from agricultural drainage may be significant during certain flow conditions in areas where metals such as copper and zinc are added as agricultural amendments. Copper loads for sampling periods in July and September 1996 and in MayJune 1997 show increases of dissolved and colloidal copper and in colloidal zinc between Colusa and Verona, the reach of the Sacramento River along which the Colusa Basin Drain, the Sacramento Slough, and other agricultural return flows are tributaries. Monthly sampling of these two agricultural drains by the USGS National Water-Quality Assessment Program shows seasonal variations in metal concentrations, reaching maximum concentrations of 4 to 6 micrograms per liter in "dissolved" (0.45-micrometer filtrate) copper concentrations in May 1996, December 1996, and June 1997. The total (dissolved plus colloidal) load of copper from the Colusa Basin Drain in June 1997 was 18 kilograms per day, whereas the copper load in Spring Creek, which drains the inactive mines on Iron Mountain, was 20 kilograms per day during the same sampling period. For comparison, during the January 1997 flood, the copper load in Spring Creek was about 1,100 kilograms per day and the copper load in the Yolo Bypass was about 7,300 kilograms per day. The data clearly indicate that most copper and zinc loads during the January 1997 flood entered the Sacramento River upstream of Colusa, and upstream of the influence of the most intense agricultural drainage return flows in the Sacramento River watershed.

This study has demonstrated that some trace metals of environmental significance (cadmium, copper, and zinc) in the Sacramento River are transported largely in dissolved form at upstream sites (below Shasta Dam, below Keswick Dam, and at Bend Bridge) proximal to the mineralized areas of the West Shasta and East Shasta mining districts. In contrast, these trace metals are transported largely in colloidal form at downstream sites (Colusa, Verona, Freeport, and Yolo Bypass). Aluminum, iron, and lead were observed to be transported predominantly in the colloidal phase at all mainstem Sacramento River sampling sites during all sampling periods in this study. Despite continuous water treatment, which has removed 85 to 90 percent of the cadmium, copper, and zinc from the mine drainage at Iron Mountain, Spring Creek remains a significant source of these metals to the Sacramento River system.

\section{Introduction}

The Sacramento River is the largest river in California in length (327 $\mathrm{mi}$ or $526 \mathrm{~km}$ ) and discharge (mean annual runoff of 16,960,000 acre-ft per year; Anderson and others, 1997). The river is of critical 
importance to the economy of the state because it supplies irrigation water to farms of the Central Valley (the Sacramento Valley as shown in fig. 1 and the San Joaquin Valley, not shown), provides the greatest source of fresh water to San Francisco Bay and the Sacramento-San Joaquin Delta estuary (collectively referred to hereinafter as the Bay-Delta), and provides drinking water to millions of urban residents in both northern and southern California. Although the water quality of the Sacramento River is generally suitable for most uses, the river is impacted by mine drainage, urban runoff, point sources, and nonpoint sources such as agricultural runoff (California State Water Resources Control Board, 1992). The major waterquality impairments in the Sacramento River are attributed to metals and pesticides, although the causes of some aquatic toxicity in the watershed remain undetermined (Larsen, 1998).

One major source of metals to the Sacramento River is drainage from inactive mines in the Iron Mountain area of the West Shasta mining district. During mining and smelting activities from the 1880 s to the 1960s, the acid mine drainage from Iron Mountain discharged directly to Spring Creek, a tributary to the Sacramento River upstream of Redding. The hydrology of the Sacramento River in the area upstream of Redding is affected considerably by several aspects of the Central Valley Project (CVP). Key features of the CVP and years completed are Shasta Dam, 1943-1945; Keswick Dam, 1950; Whiskeytown Lake, 1963; and the Spring Creek Power Plant (SCPP), 1963. The Spring Creek Debris Dam (SCDD) was completed in 1963 to prevent siltation in the tail race of the SCPP, and also to regulate the acid mine drainage in Spring Creek, which was a known threat to aquatic life (U.S. Environmental Protection Agency, 1992). At least 30 fish kills during the period 1940-1969 near Redding were associated with metal-rich, acid drainage from Iron Mountain by way of Spring Creek (Nordstrom and others, 1977). Limited treatment of Iron Mountain mine drainage to remove copper $(\mathrm{Cu})$ by iron $(\mathrm{Fe})$ cementation was done from the 1970s until the early 1990s, with variable success. An emergency limeneutralization plant was required by the U.S. Environmental Protection Agency during 3 to 4 months of the wet season from 1989 to 1994 . Since November 1994, the most concentrated acid discharges from the mines at Iron Mountain have been treated year-round by lime neutralization, removing about 85 percent of the copper and about 90 percent of the zinc ( $\mathrm{Zn})$ and cadmium $(\mathrm{Cd})$ compared with untreated loads (Richard Sugarek, U.S. Environmental Protection Agency, written commun., 1997).

Despite the ongoing water treatment at Iron Mountain, a significant reach of the Sacramento River-more than 200 river mi downstream of Keswick Dam - may be affected by elevated trace metal concentrations as a result of significant runoff events of acid mine drainage by way of Spring Creek. The Bureau of Reclamation manages releases of water from Spring Creek Reservoir under a 1980

Memorandum of Understanding (MOU) with several other agencies. Under the MOU, the primary goal of water management in the Spring Creek area has been to achieve compliance with water-quality standards for metals at a point immediately downstream of Keswick Dam. Compliance usually has been achieved by mixing water from Spring Creek Reservoir with water from Shasta Lake released from Shasta Dam and from Whiskeytown Lake, which flows into Keswick Reservoir by way of the Spring Creek Power Plant (fig. 2). On several occasions since 1963, the water Ievel in spring Creek Reservoir has exceeded the spillway elevation, causing uncontrolled release of acidic water to Keswick Reservoir and occasionally exceeding water-quality standards at Keswick Dam. The impacts of such metal releases on aquatic life in Keswick Reservoir and the Sacramento River below Keswick Dam have been documented to some extent in terms of acute toxicity to fish (U.S. Environmental Protection Agency, 1992). However, much less is known regarding the chronic impacts of metals on ecosystems or the downstream impacts and transport of the metals from mine drainage in this area.

Metals such as cadmium, copper, lead $(\mathrm{Pb})$, and zinc enter Keswick Reservoir as part of the acid mine drainage from Spring Creek. Prior to part-time lime neutralization in 1989, the acid water of Spring Creek below the SCDD had $\mathrm{pH}$ values generally less than 3 . During 1994-1998, pH values in Spring Creek below the SCDD have been commonly between 4 and 5 . Where the Spring Creek waters mix with near-neutral, dilute waters of Keswick Reservoir, the $\mathrm{pH}$ rises to near 7 and the metals are partially to completely redistributed in the form of suspended colloids or other solid forms composed primarily of hydrous iron and aluminum oxides (Nordstrom and others, 1999). These solids and associated metals, and remaining dissolved metals, can be transported out of Keswick Reservoir 


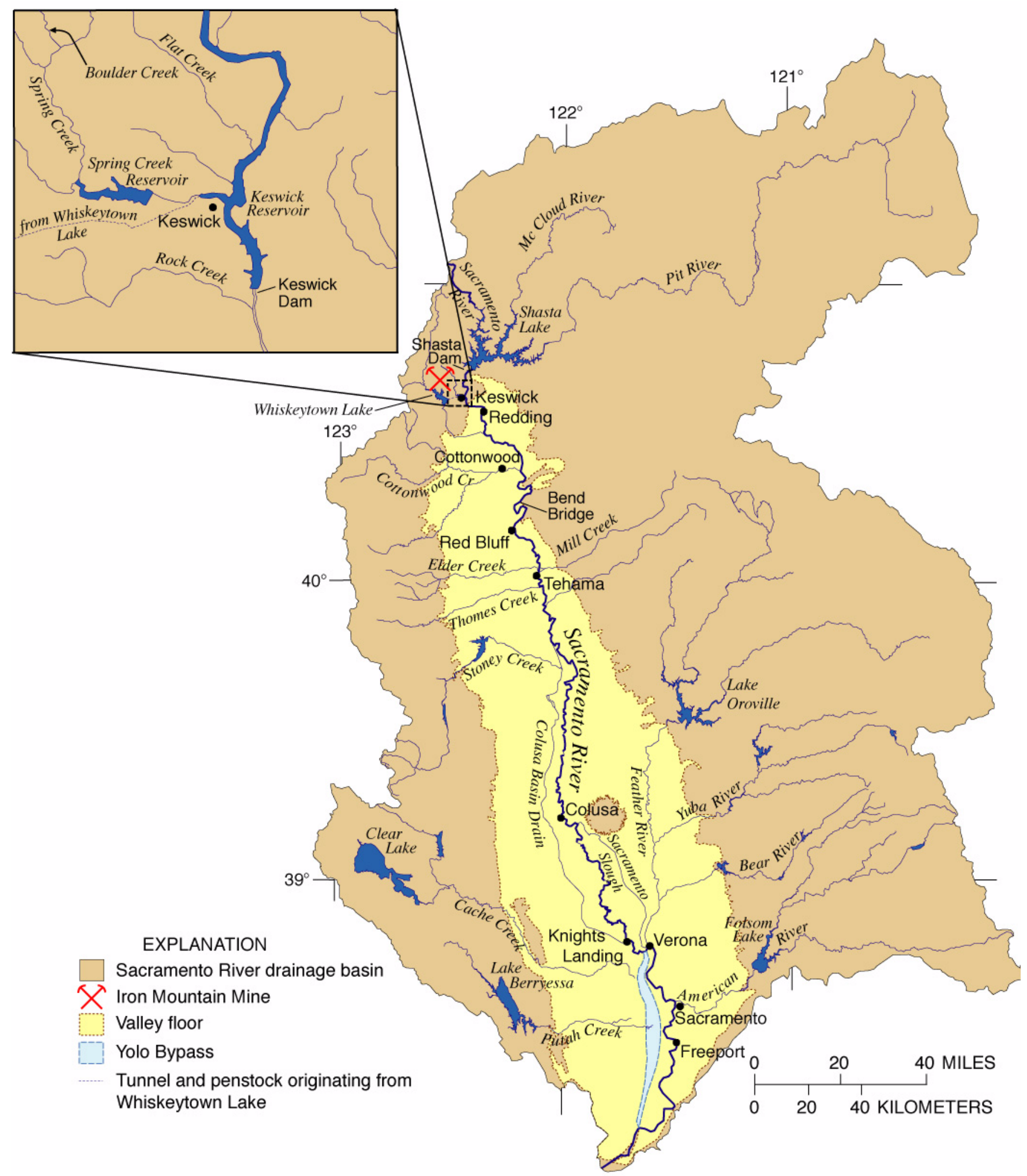

Figure 1. Location map of Sacramento River watershed, California. 


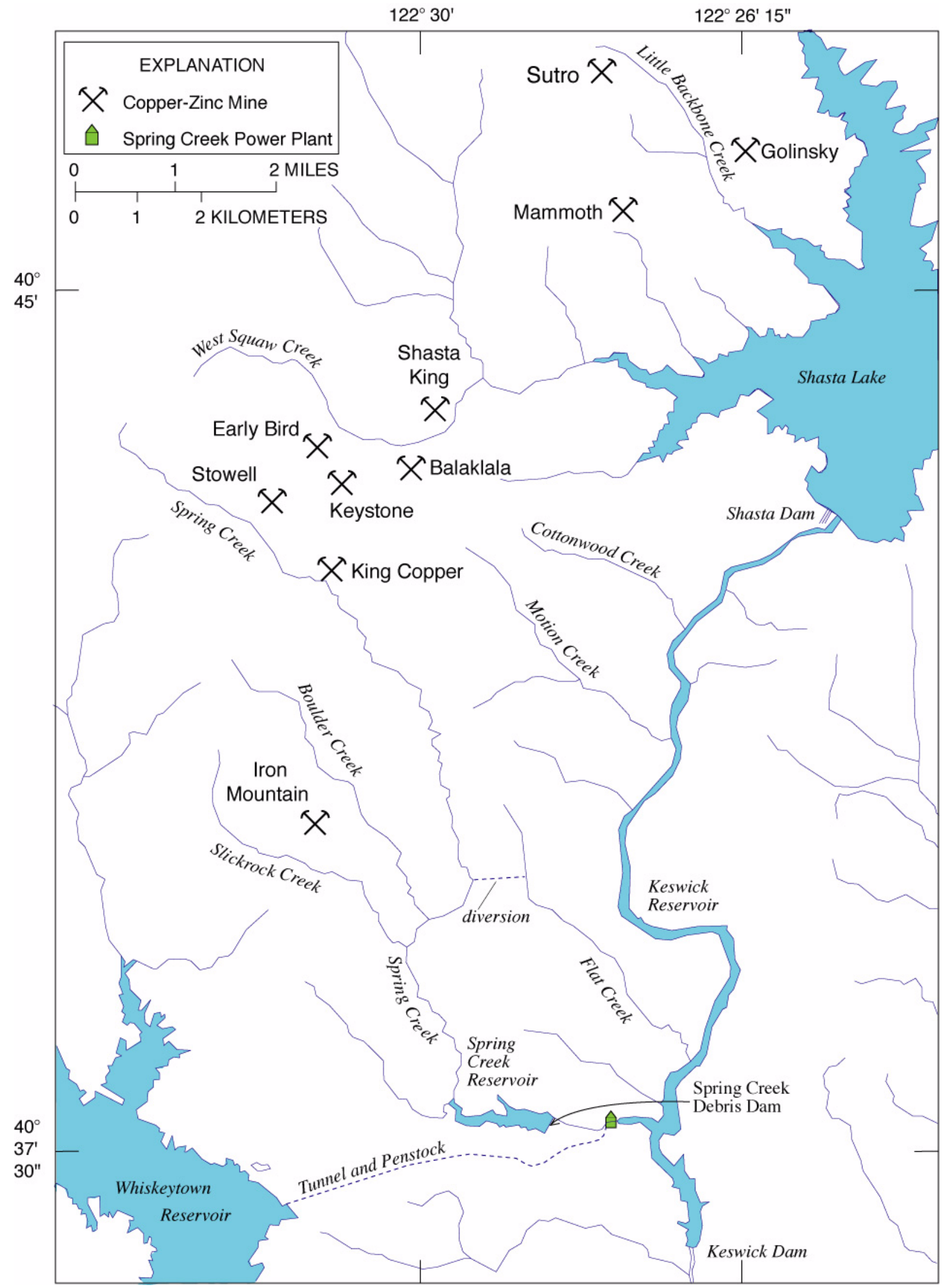

Figure 2. Location map of West Shasta mining district, Shasta County, California. 
and into the Sacramento River, and then transported toward the Bay-Delta. In sufficiently high concentrations, the metals can be toxic to aquatic life; numerous fish kills have occurred in the reach of the Sacramento River below Keswick Reservoir. Monitoring programs for metals downstream of Keswick Reservoir have been designed primarily for the assessment of compliance with water-quality standards. Water samples collected by other federal and state agencies (and their contractors) for metal analyses have included both unfiltered and filtered samples. Unfiltered (whole water) samples typically have been subjected to total recoverable analysis (an incomplete digestion).

Sample filtration typically is done using conventional $0.45-\mu \mathrm{m}$ pore-size filters. Colloidal forms of metal are known to pass through conventional $0.45 \mu \mathrm{m}$ pore-size filters (Kimball and others, 1995; Church and others, 1997). Therefore, neither the fate nor the transport of colloidal metals have been addressed quantitatively in these sampling programs. Knowledge of the fate of the colloidal metals is crucial in understanding sources of metals and how far downstream metals from mine drainage are transported, and in distinguishing metals originating from mine drainage from those with other sources, such as agricultural or urban runoff.

\section{Previous Work and Related Ongoing Studies}

One of the more extensive monitoring programs for metals in the Sacramento River Watershed is located in Sacramento County and is called the Coordinated Monitoring Program (CMP).

Participating agencies in the CMP are the Sacramento Regional County Sanitation District (a cooperating agency on this study), the Sacramento County Water Agency, and the City of Sacramento. This program began in 1991 (Larry Walker Associates and Brown and Caldwell, 1994). Sampling sites were chosen on the Sacramento River both upstream and downstream of the City of Sacramento. The American River, just below Folsom Dam (fig.1) and just before the confluence with the Sacramento River, also was sampled. Another comprehensive monitoring program in the watershed, the Sacramento River Watershed Program, is administered by the Sacramento Regional County Sanitation District and is designed to assess toxicity of metals and pesticides to aquatic organisms in the Sacramento River and to quantify metal loads to the Bay-Delta.
The California Regional Water Quality Control Board (hereinafter called the Regional Water Board) has recently completed a study of metal concentrations and loads in the Sacramento River system (Connor and Clark, 1999) on the basis of sampling during 19931995. That study showed that metal loads were greatest during wet-season run-off conditions. Studies of aquatic toxicity by the Regional Water Board (Connor and others, 1994; Larsen, 1998; Larsen and others, 1998) on the basis of water sampling during 1993-1997 indicate that metals generally did not cause toxicity to aquatic organisms downstream of Shasta Dam. However, in the Upper Sacramento River, upstream of Shasta Lake (fig. 1), these studies found that nickel (Ni) caused toxicity to Ceriodaphnia dubia.

Trace metals are monitored in the Sacramento River Basin as part of the United States Geological Survey's (USGS) National Water-Quality Assessment (NAWQA) Program (Domagalski and others, 1998). An intensive period of monthly sampling for that program occurred from February 1996 to February 1998 at 12 sites in the Sacramento River Basin, including 4 sites on the Sacramento River: Bend Bridge, Colusa, Verona, and Freeport (fig. 1). A less intensive period of monthly sampling at only the Freeport site has continued since March 1998. Water samples from the NAWQA Program taken for analysis of trace metals are filtered through $0.45-\mu \mathrm{m}$ pore-size capsule (Gelman) filters. The detection limit for most trace metal determinations using the standard methods of the USGS's National Water Quality Laboratory (NWQL) during the intensive sampling period was 1 $\mu \mathrm{g} / \mathrm{L}$. Although barely suitable for some metals, such as copper and zinc, this relatively high detection limit commonly result in nondetections for many trace metals of interest in filtered samples, including cadmium and lead.

Studies of metal transport in other watersheds have provided important information regarding the role of colloids, especially in other waterbodies that receive metal-rich, acidic drainage from historic mining areas. Extensive colloid transport of metals was documented in the upper Arkansas River, downstream of Leadville, Colorado (Kimball and others, 1995). Similar effects were seen in a detailed study of metal transport in the upper Animas Basin, which includes Silverton, Colorado (Church and others, 1997). 


\section{Purpose and Scope}

Because of limitations in trace metal detection limits of the USGS's standard NAWQA protocols and the relatively limited extent of the NAWQA sampling network in the Sacramento River watershed, the present study was designed to assess metals transport in the Sacramento River. Water samples were taken during six sampling periods between July 1996 and June 1997, and were processed using tangential-flow ultrafiltration techniques to separate colloidal solids from the aqueous phase, resulting in better estimates for dissolved metals. A related report (Volume 1 [Alpers and others, 2000]) describes the methods and the quality assurance and quality control aspects of the USGS metals transport study, and gives the results of metal concentration data. The present report (Volume 2) contains interpretations of metals transport in the Sacramento River system in terms of metal loads. The metal loads are computed for dissolved and colloidal fractions of the water, as well as for whole-water samples using a partial digestion related to totalrecoverable metals (Alpers and others, 2000).

The scope of this report (Volume 2) is limited to interpretation of loads for six metals: aluminum (Al), cadmium, copper, iron, lead, and zinc. Information from this study on mercury $(\mathrm{Hg})$ loads in the Sacramento River watershed are discussed in a separate report (David Roth, U.S. Geological Survey, written commun., 1999). Another companion report from this study (Cain and others, 2000) describes metal bioaccumulation in caddisfly larvae taken from five sampling sites on the Sacramento River between Keswick Dam and Tehama plus a site on a tributary, Cottonwood Creek (fig. 1). The chemistry of streambed sediments from these six sites was documented in a previous report (Alpers and others, 2000).

Appendix 10 this report contains tables of data with loads of selected metals ( $\mathrm{Al}, \mathrm{Cd}, \mathrm{Cu}, \mathrm{Fe}, \mathrm{Pb}, \mathrm{Hg}$, and $\mathrm{Zn}$ ) in dissolved form, colloidal form, and whole water (total recoverable analyses). In Appendix 2, metal loads at each sampling point are compared with the sum of the loads at Freeport and the Yolo Bypass. Tables of load data used in mass balance calculations are given in Appendix 3 Spring Creek arm of Keswick Reservo1r) and Appendix 4 (Keswick Reservoir). Other appendixes include plots of dissolved and colloidal loads for miscellaneous metals (Appendix 5) and hydrographs for selected sampling periods showing variations in discharge in relation to the time of samplin\$ (Appendix 6).

\section{Acknowledgments}

The authors thank the numerous individuals at USGS and other agencies who made this study possible through their hard work and cooperation. Field personnel at the USGS who contributed to this study include Steven Gallanthine, Michael Hunerlach, Mark Johnson, William Kinsey, Franklin Moseanko, Cathy Munday, and Darnella Murphy. We also appreciate the assistance of several other USGS employees: James Baker, D’An Brent, Susan Davis, Yvonne Gobert, Donna Knifong, Glenn Schwegmann, and David Uyematsu in Sacramento, California; George Aiken, Terry Brinton, D. Kirk Nordstrom, Dale Peart, David Roth, and Robert Stallard in Boulder, Colorado; Daniel Cain, James Carter, Steven Fend, and Samuel Luoma in Menlo Park, California; and Briant Kimball in Salt Lake City, Utah. Several employees of the Bureau of Reclamation provided assistance during sample collection in the ReddingShasta area, including Stuart Angerer, Sean Duffy, and Janet Martin. We thank Rosemary Clark, Mary James, Robert Seyfried, Jerry Troyan, and their colleagues at the Sacramento Regional County Sanitation District for help in securing funds for this effort and for useful suggestions during its execution, and Gregory Franz at the California State Water Resources Control Board for assistance with administration of the 205(j) grant. We also thank Richard Sugarek at the U.S.

Environmental Protection Agency for providing funds though the U.S. Environmental Protection Agency (EPA) Superfund Program to add sampling sites in the Spring Creek area, and Nicholas Iadanza of the National Marine Fisheries Service for assisting with funding for the caddisfly work.

\section{Computation of Metal Loads}

The instantaneous load of a given constituent transported by a river is the product of the concentration of that constituent at a given time and the instantaneous discharge of the river at that same time. In practice, it is usually difficult, if not impossible, to obtain truly instantaneous water-quality samples and discharge measurements, but most river systems do not change appreciably over the course of 
a day; so, what is commonly calculated is an average load expressed in kilograms per day $(\mathrm{kg} / \mathrm{d})$. The assumptions made by this approach are that both the concentration of the constituent and the discharge of the river remain relatively constant for the day in which the measurements are made. The actual formula is:

$$
\begin{gathered}
\text { Load }(\mathrm{kg} / \mathrm{d})=\text { Concentration }(\mu \mathrm{g} / \mathrm{L}) \times \\
\text { Discharge }\left(\mathrm{m}^{3} / \mathrm{s}\right) \times 0.0864
\end{gathered}
$$

\section{Discharge}

The flow regime of the Sacramento River is highly seasonal, in response to the mediterranean climate of northern California. The wet season in the watershed ranges typically from November to May, with snowmelt occurring normally during April through June; warm rains earlier in the winter have been known to cause extensive melting associated with extremely high discharge such as the New Year's flood of 1997 (Hunrichs and others, 1998). The six sampling periods for the present study were chosen to span a variety of flow conditions. The sampling periods in July, September, and November 1996 and during May-June 1997 occurred during relatively lowflow conditions whereas the sampling periods during December 1996 and January 1997 were during highflow conditions (fig. 3).

Discharge in the Sacramento River and its major tributaries is managed for the purposes of flood control, irrigation, and aquatic habitat. Several water diversions affecting the Sacramento River cause significant seasonal changes in the flow regime. Diversions for agricultural use include the TehamaColusa and Glenn-Colusa canals (fig. 3). Return flows from irrigation on the western side of the Sacramento River are collected in the Colusa Basin Drain (figs. 1 and 3), which enters the Sacramento River downstream of Colusa and upstream of the confluence of the Sacramento River with the Feather River. On the eastern side of the valley, agricultural return flows are collected in the Sacramento Slough (figs. 1 and 3). The agricultural diversions are most active during irrigation season, typically May through October. Flood control diversions in the Sacramento River system include the Sutter and Yolo bypasses, which are typically most active during December through April (figs. 3D, 3E).

As a result of the various diversions and water management practices, the flow regime on the
Sacramento River was somewhat different during each of the six sampling periods in this study. The diagrams in figure 3 indicate the relative discharge of the Sacramento River and its tributaries and a distributary (the Yolo Bypass) for each of the sampling periods. During all six sampling periods, the discharge of the Sacramento River decreased between Red Bluff and Colusa. During low-flow conditions this decrease was primarily because of agricultural diversions, whereas during high-flow conditions this decrease resulted from flood-control diversions.

\section{Dissolved Loads}

Tables of load data Appendix 1. were calculated according to the formula in Equation (1) using the concentration and discharge data from Alpers and others (2000). Dissolved loads were computed using concentration data from the tangential-flow ultrafiltrates that were derived using 10,000 daltons, or Nominal Molecular Weight Limit (NMWL) membranes, equivalent to an effective poresize diameter of $0.005 \mu \mathrm{m}$ (Millipore Corporation, 1993). Other studies typically have measured concentrations using $0.45-\mu \mathrm{m}$ pore-size filters, which tend to yield higher values than the ultrafilters.

Conventional filtrates were also produced using a $0.45-\mu \mathrm{m}$ pore-size capsule filter (Gelman) and a $0.40-\mu \mathrm{m}$ pore-size membrane filter (Nuclepore). Metal concentrations in these conventional filtrates were generally higher than those observed in the ultrafiltrates, especially for such elements as aluminum, iron, and lead, which are associated with fine-grained colloids. It is very important to recognize these differences if the "dissolved" data reported here are to be compared with "dissolved" loads based on conventional filtrates from other studies.

\section{Colloidal Loads}

Colloidal loads were calculated in a manner similar to that used for dissolved loads, by multiplying the discharge of the river or creek by the equivalent colloid concentration of the constituent. The equivalent colloid concentration is directly analogous to the dissolved concentration of a constituent; both use units of micrograms per liter (or milligrams per liter), and both represent the mass of the constituent present per unit volume of water. The dissolved concentration represents the amount of the constituent 


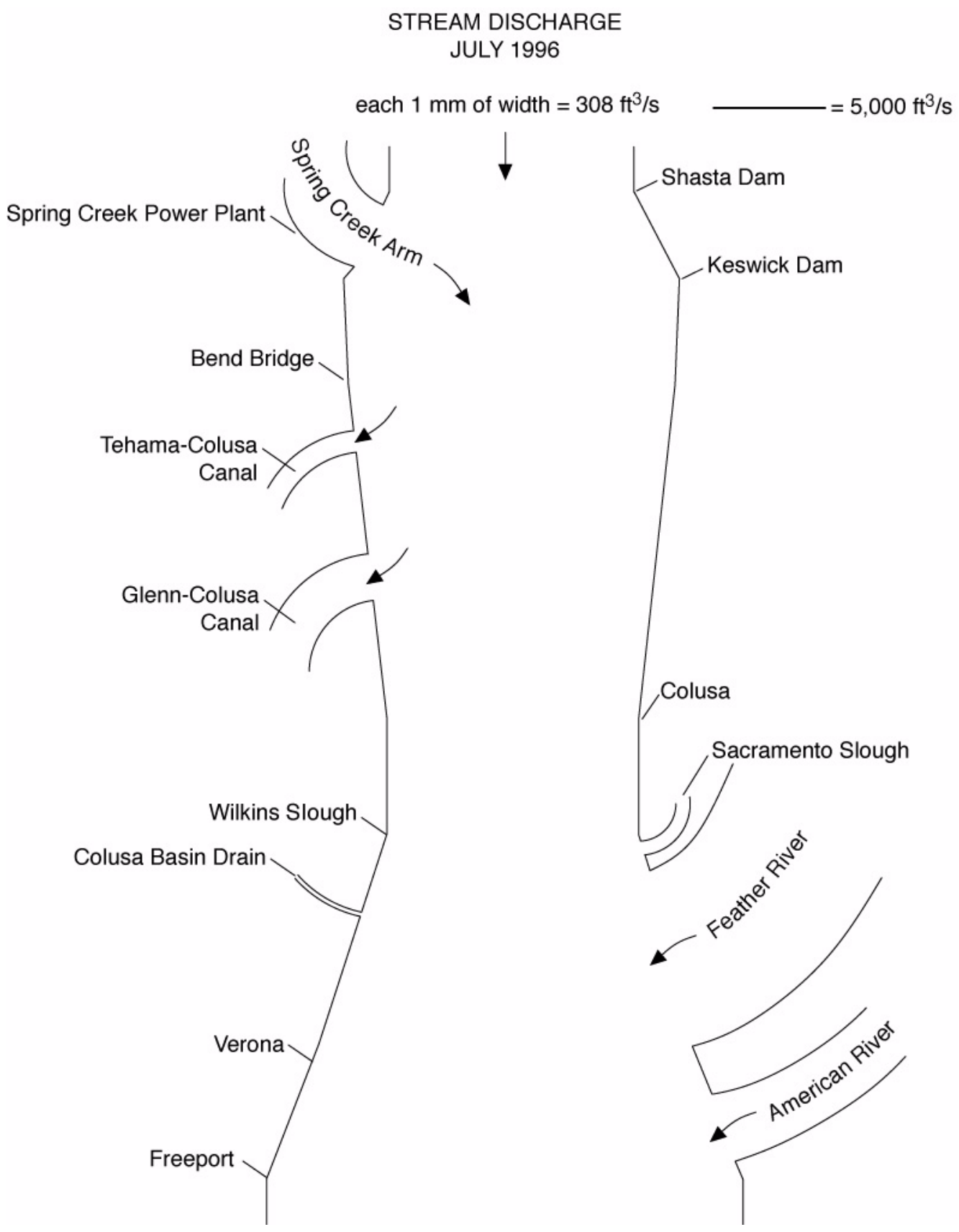

Figure 3A. Diagram showing magnitude of mean discharge in the Sacramento River, California, relative to major tributaries and diversions during the July 11-18, 1996 sampling period. The width of the river is proportional to discharge. $\mathrm{ft}^{3} / \mathrm{s}$, cubic feet per second; $\mathrm{mm}$, millimeter.

that is dissolved, whereas the equivalent colloid concentration represents the amount of the constituent that is contained in or on the colloids. The equivalent colloid concentration of a constituent in a colloidal sample (in micrograms per liter) was computed as the product of the suspended colloid concentration (in milligrams per liter) and the concentration of the constituent of interest in the colloid sample (in micrograms per milligram). The method used to calculate the suspended colloid concentration using aluminum concentrations in colloidal and whole water samples is described by Alpers and others (2000). The colloidal loads in Appendix 1 of this report were calculated using Eq. 1, where the concentration is the 


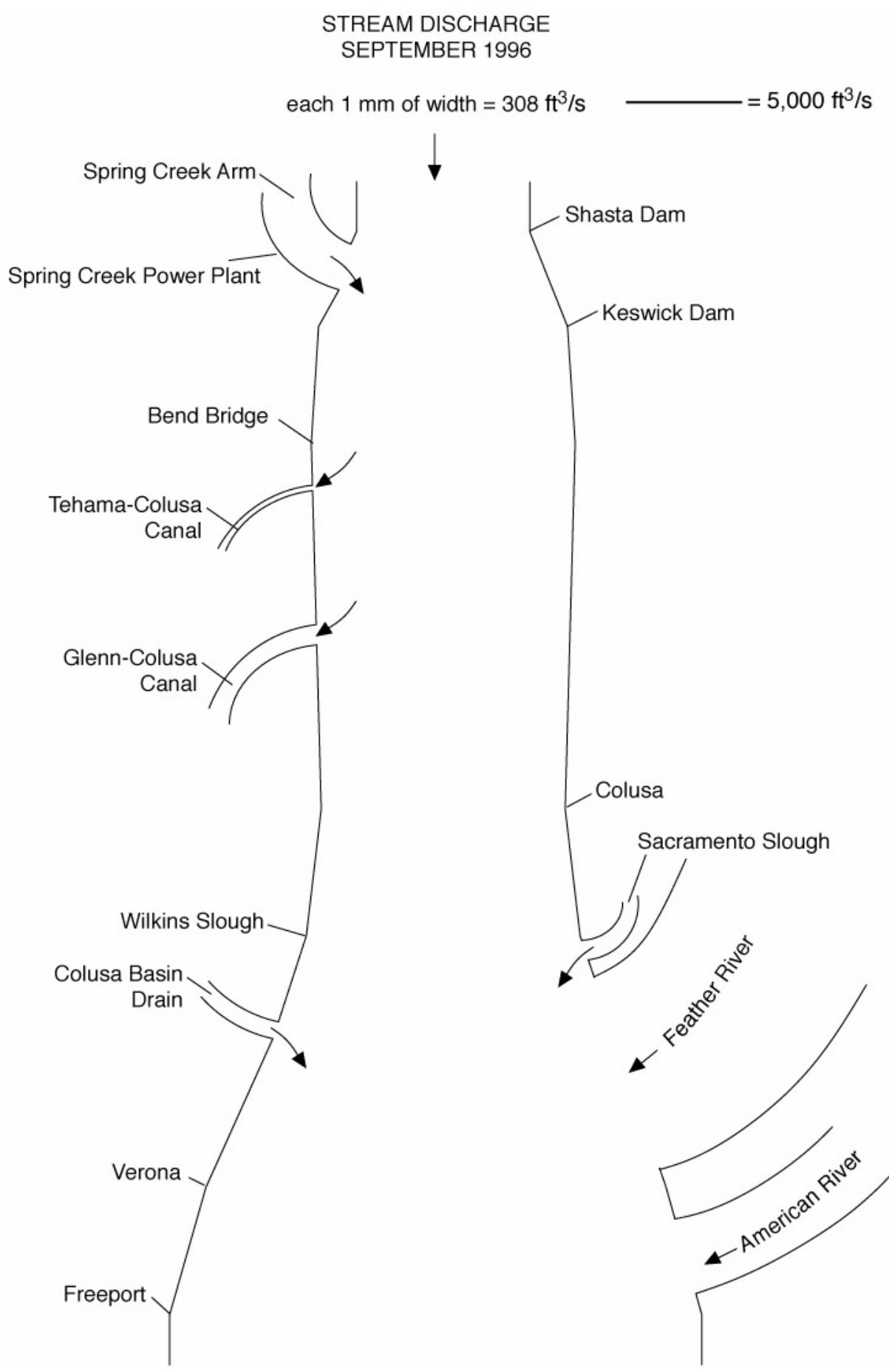

Figure 3B. Diagram showing magnitude of mean discharge in the Sacramento River, California, relative to major tributaries and diversions during the September 18-26, 1996 sampling period. The width of the river is proportional to discharge. $\mathrm{ft}^{3} / \mathrm{s}$, cubic feet per second; $\mathrm{mm}$, millimeter.

equivalent colloid concentration, equal to the product of colloid concentration and the concentration of the constituent associated with the colloids, using data listed in Appendix 5 of Alpers and others (2000).
For colloid samples with speciation data from sequential extractions, the speciated colloid loads were calculated in exactly the same way as described above, substituting the speciation concentration data 


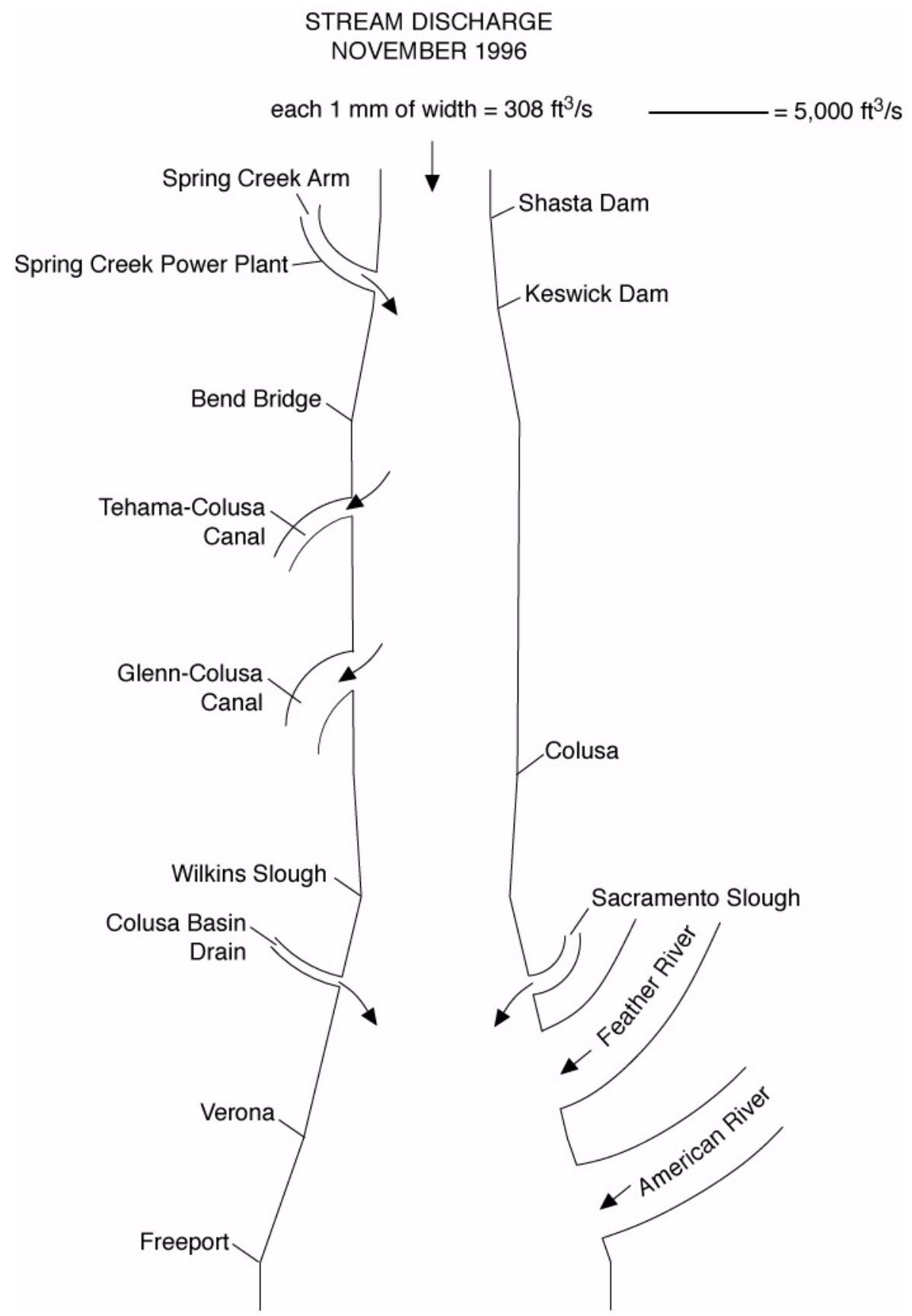

Figure 3C. Diagram showing magnitude of mean discharge in the Sacramento River, California, relative to major tributaries and diversions during the November 12-22, 1996 sampling period. The width of the river is proportional to discharge. $\mathrm{ft}^{3} / \mathrm{s}$, cubic feet per second; $\mathrm{mm}$, millimeter.

(Appendix 5 in Alpers and others, 2000) for the concentration of the constituent in the colloid sample.

\section{Transport Plots}

The bar plots in figures 4 through $9 \mathrm{~d}$ splay the dissolved and colloidal loads or $\mathrm{Al}, \mathrm{Ca}, \mathrm{Cu}, \mathrm{Fe}, \mathrm{Pb}$, and Zn (respectively) for mainstem Sacramento River sampling sites, during each of the six sampling periods, in downstream order from left to right. These plots have a break in the y-axis, about two-thirds of the distance from the $\mathrm{x}$-axis, above which the scale changes from linear to logarithmic. The bars that cross this axis break are also broken, so that it is easy to distinguish the points plotted on the logarithmic scale. The reason for this construction is that the loads for each metal typically varied over three to four orders of magnitude between the smallest and largest 


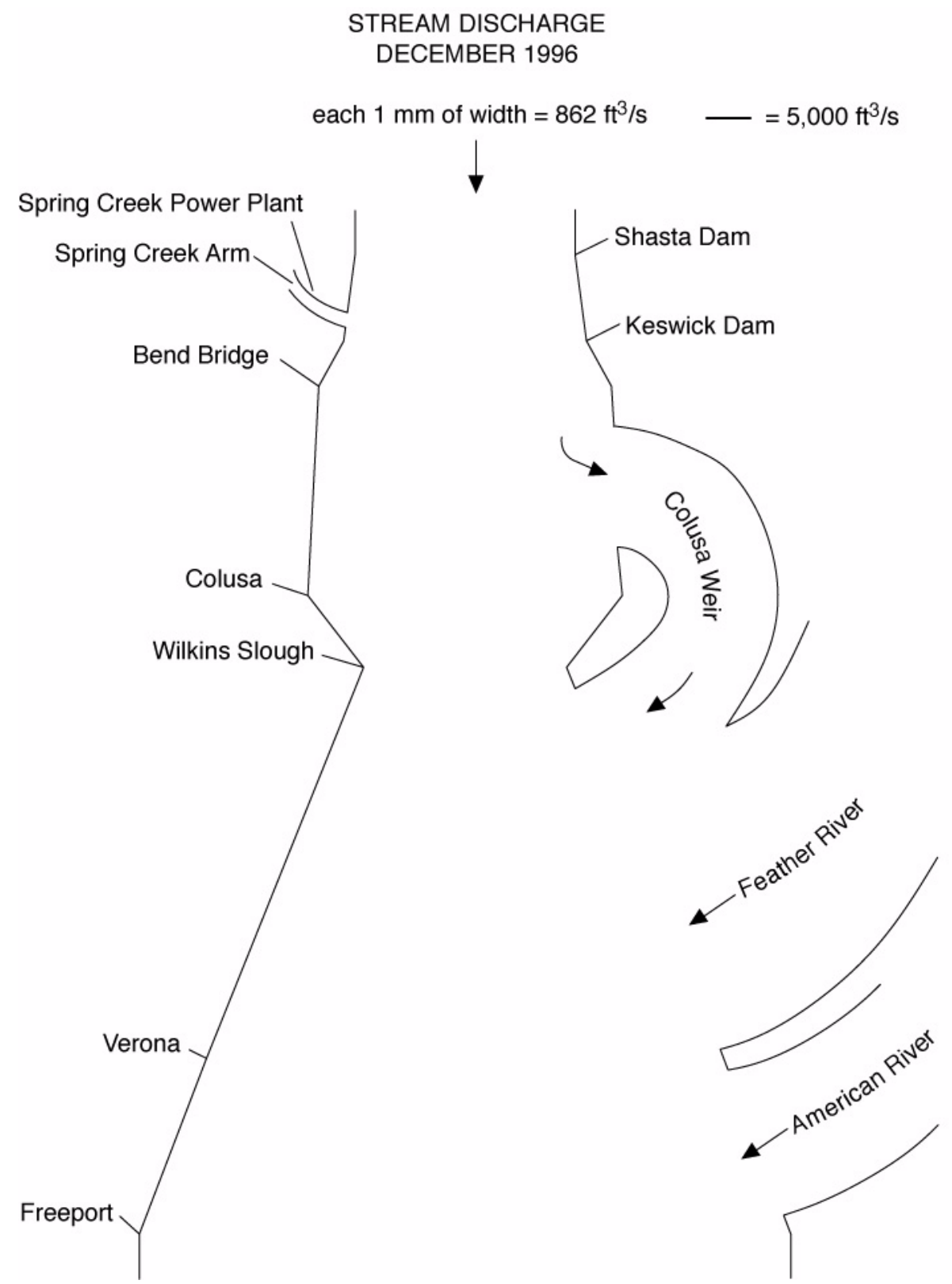

Figure 3D. Diagrams showing magnitude of mean discharge in the Sacramento River, California, relative to major tributaries and diversions during the December 11-18, 1996 sampling period. The width of the river is proportional to discharge. $\mathrm{ft}^{3} / \mathrm{s}$, cubic feet per second; $\mathrm{mm}$, millimeter.

measurements. To make direct comparisons between the low-discharge sampling periods (for example, November 1996) and the high-discharge period of January 1997, the broken axis, linear-log plot was chosen.

A complementary group of plots (figs. 10 through 15) shows the transport for eacn element with a set of six graphs, one for each sampling period. On these graphs, the measured (or estimated) discharges, the calculated concentrations of suspended colloids, and the metal concentrations in the colloid concentrates are shown. Superimposed on each of these graphs is a series of stacked bar graphs denoting the dissolved and colloidal metal loads for each site on a linear scale. The overall heights of the bars are proportional to the total (dissolved plus colloidal) metal load, with the number above the bar denoting the value of the total load, in kilograms per day. It is important to note that each of the six graphs for a given element may have a different vertical scale for each of the three parameters plotted. Whereas figures 4 through 9 compare the various loads at different times 


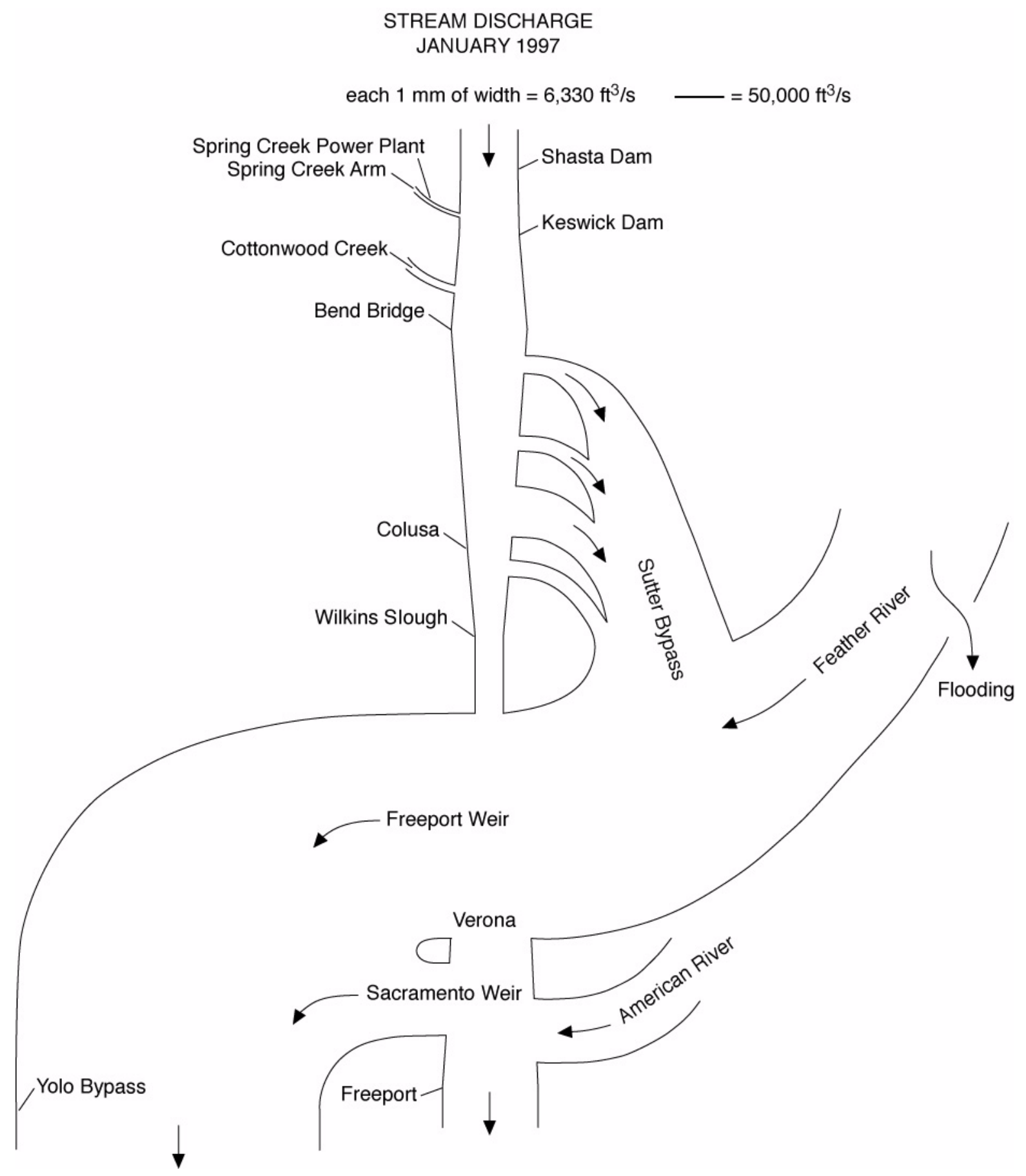

Figure 3E. Diagrams showing magnitude of mean discharge in the Sacramento River, California, relative to major tributaries and diversions during the January 2-8, 1997 sampling period. The width of the river is proportional to discharge. $\mathrm{ft}^{3} / \mathrm{s}$, cubic feet per second; $\mathrm{mm}$, millimeter.

of year, figures 10 through 15 sh ow how the loads varied with dischare anc colloid concentration, and how the proportion of dissolved loads varied with time and site. The trends and features of these transport graphs are discussed further in later sections of this report.
Load graphs for several other trace elements (chromium [Cr], cobalt [Co], nickel, and yttrium $[Y]$ are provided for general information in Appendix 5 of this report. The various features of the plots for these other elements are not discussed in this report. 


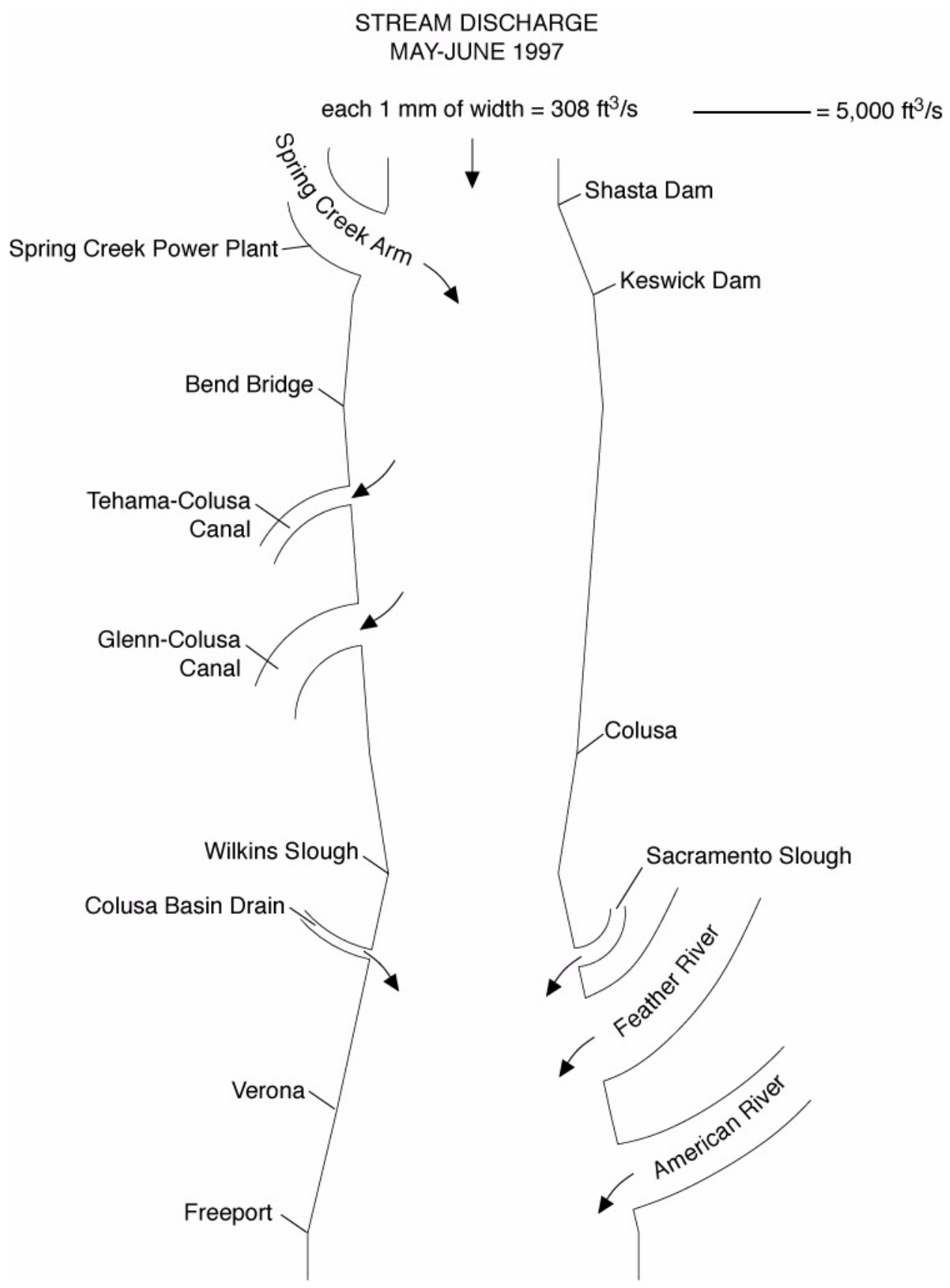

Figure 3F. Diagrams showing magnitude of mean discharge in the Sacramento River, California, relative to major tributaries and diversions during the May 28-June 6, 1997 sampling period. The width of the river is proportional to discharge. $\mathrm{ft}^{3} / \mathrm{s}$, cubic feet per second; $\mathrm{mm}$, millimeter.

\section{Total Recoverable Loads}

Total recoverable loads that are based on partial digestions of whole-water samples were calculated in a similar manner to the loads for dissolved and colloidal data. The whole-water concentrations and discharge measurements were taken from Appendices 3 and 4 of the report by Alpers and others (2000). The computed total recoverable (whole-water) loads are tabulated ih Appendix 1 f this report.

Metatconcentrations from total recoverable analyses of whole-water samples and the sum of the 
Figure 4. Plot of dissolved and colloidal aluminum loads, July 1996 to May-June (labeled as May on graph) 1997, Sacramento River, California. Al, aluminum; C, no colloidal load data available; D, no dissolved load data available. Freeport data for January 1997 is the sum of loads from the Sacramento River at Tower Bridge plus the Yolo Bypass. 


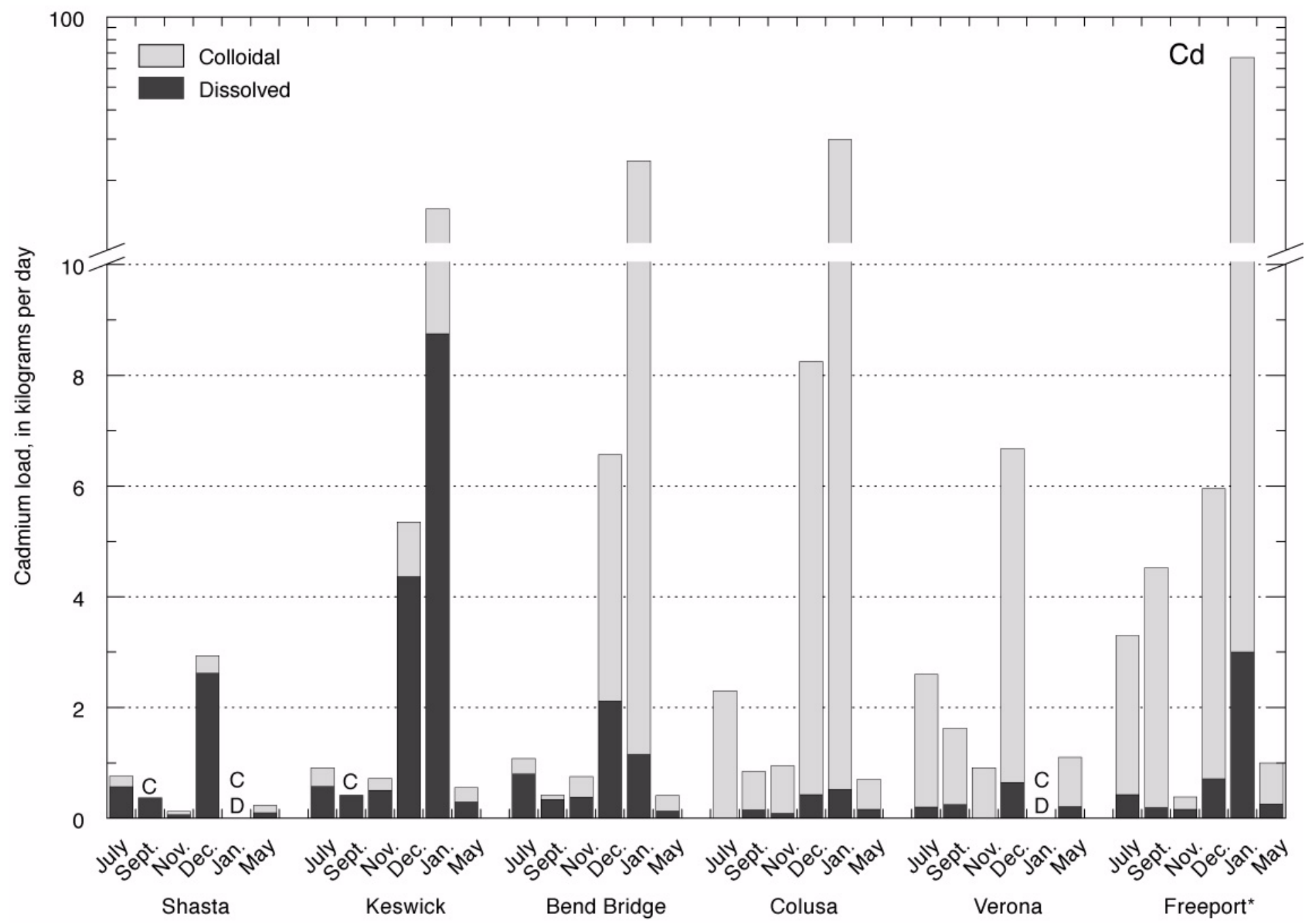

Figure 5. Plot of dissolved and colloidal cadmium loads, July 1996 to May-June (labeled as May on graph) 1997, Sacramento River, California. Cd, cadmium; C, no colloidal load data available; D, no dissolved load data available. Freeport data for January 1997 is the sum of loads from the 
Figure 6. Plot of dissolved and colloidal copper loads, July 1996 to May-June (labeled as May on graph) 1997, Sacramento River, California. Cu, copper; C, no colloidal load data available; D, no dissolved load data available. Freeport data for January 1997 is the sum of loads from the Sacramento River at Tower Bridge plus the Yolo Bypass. 


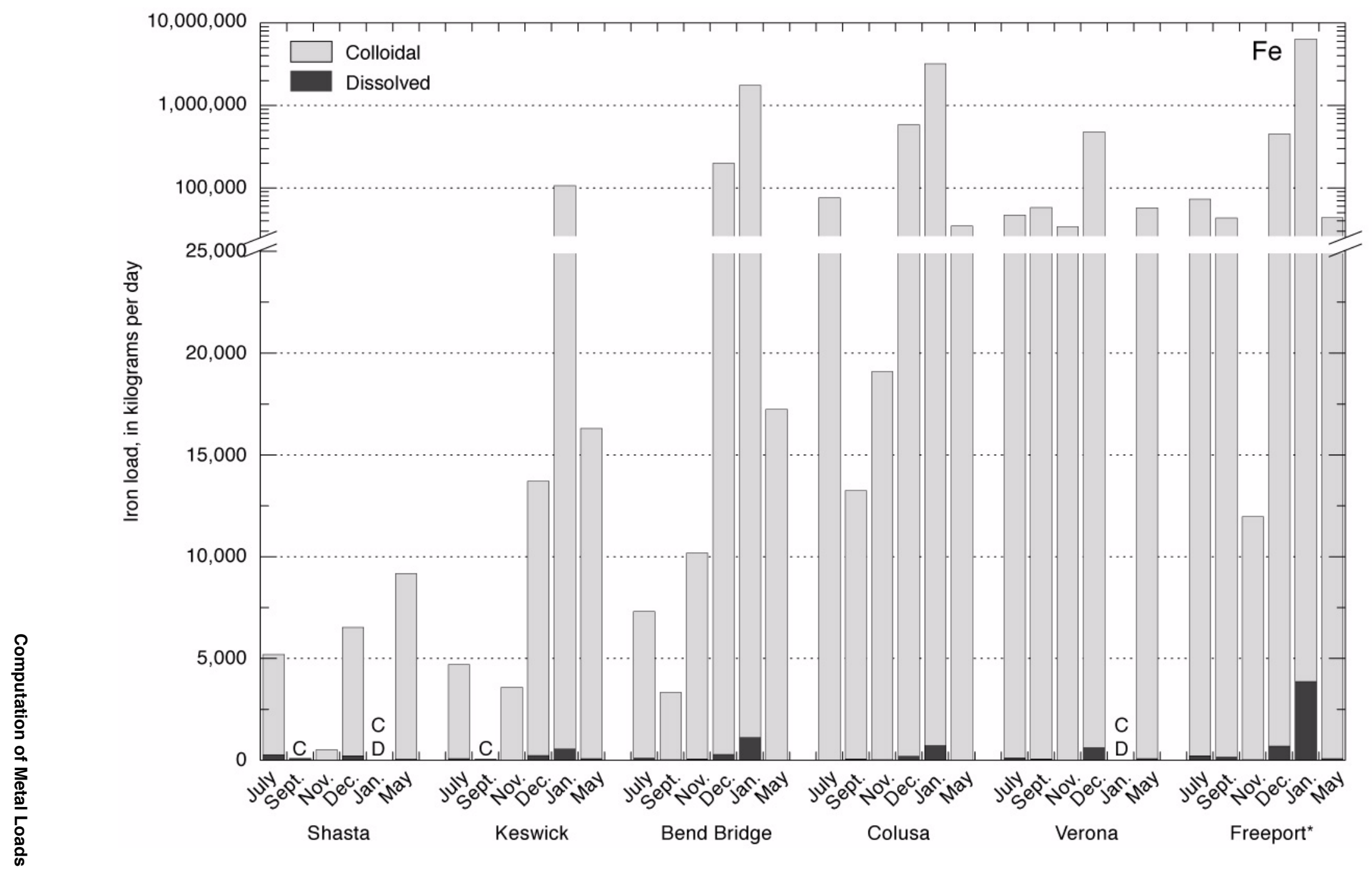

Figure 7. Plot of dissolved and colloidal iron loads, July 1996 to May-June (labeled as May on graph) 1997, Sacramento River, California. Fe, iron; C, no colloidal load data available; D, no dissolved load data available. Freeport data for January 1997 is the sum of loads from the Sacramento River at Tower Bridge plus the Yolo Bypass. 
Figure 8. Plot of dissolved and colloidal lead loads, July 1996 to May-June (labeled as May on graph) 1997, Sacramento River, California. Pb, lead; C, no colloidal load data available; D, no dissolved load data available. Freeport data for January 1997 is the sum of loads from the Sacramento River at Tower Bridge plus the Yolo Bypass.

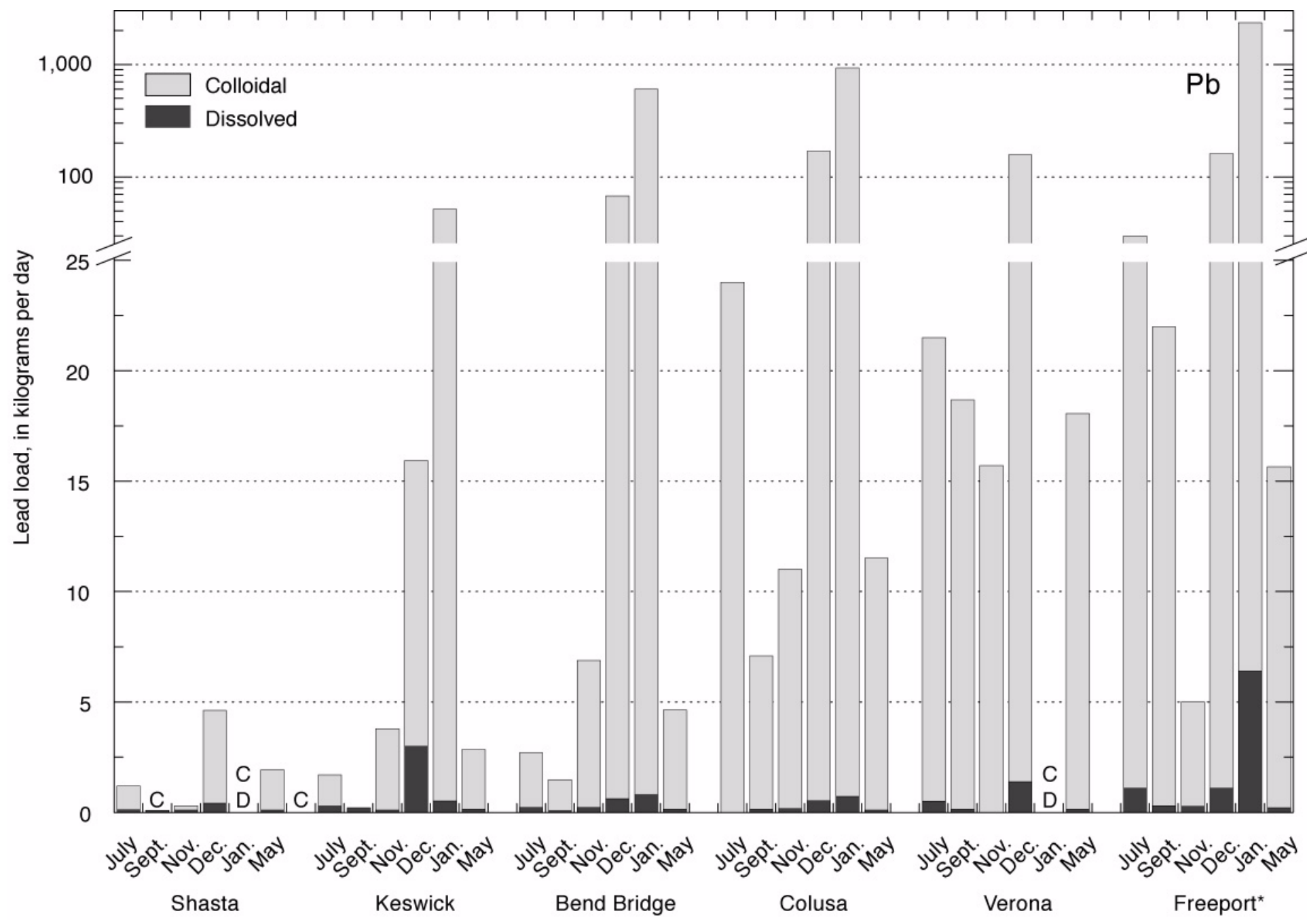




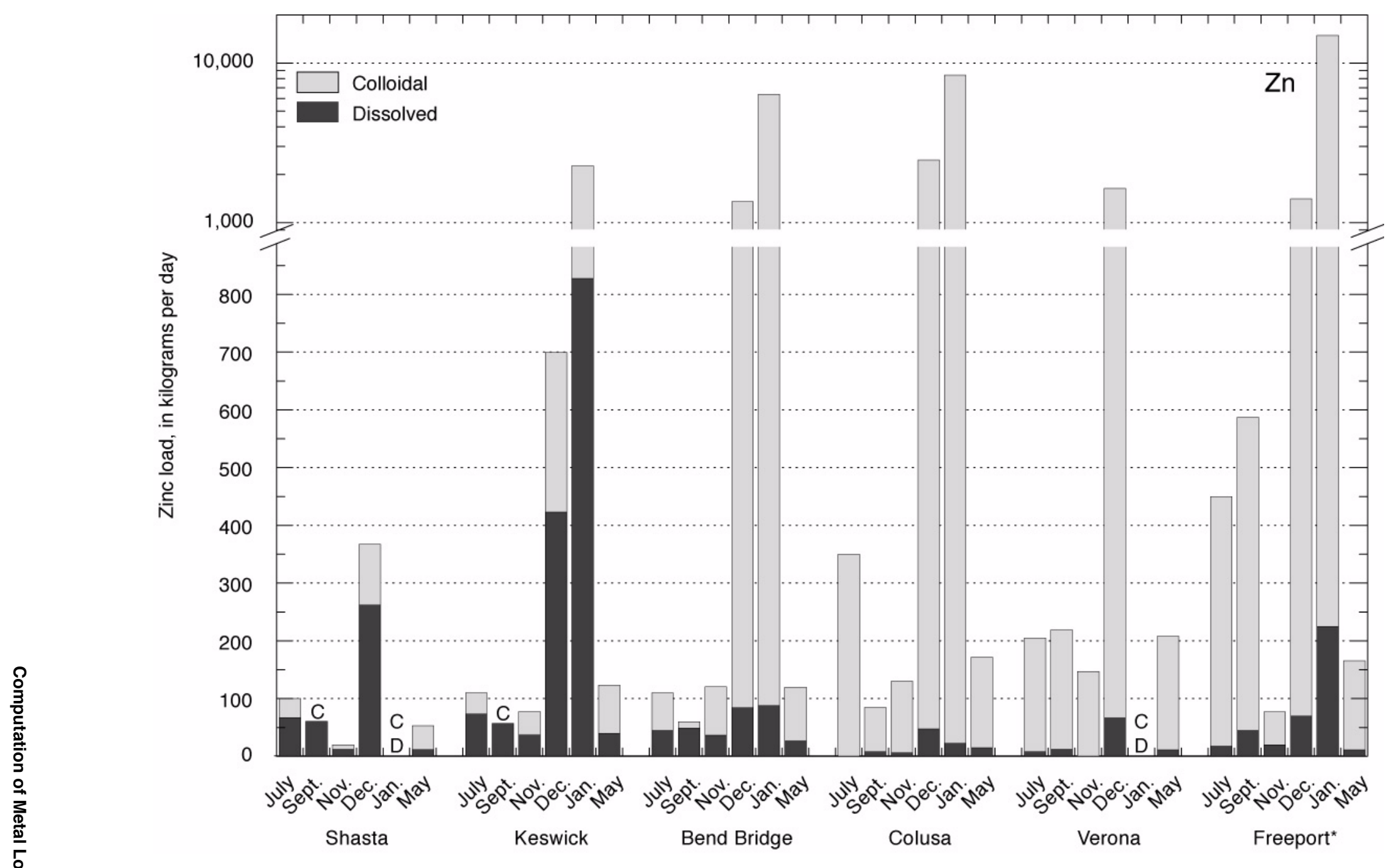

Figure 9. Plot of dissolved and colloidal zinc loads, July 1996 to May-June (labeled as May on graph) 1997, Sacramento River, California. Zn, zinc; C, no colloidal load data available; D, no dissolved load data available. Freeport data for January 1997 is the sum of loads from the Sacramento River at Tower Bridge plus the Yolo Bypass. 


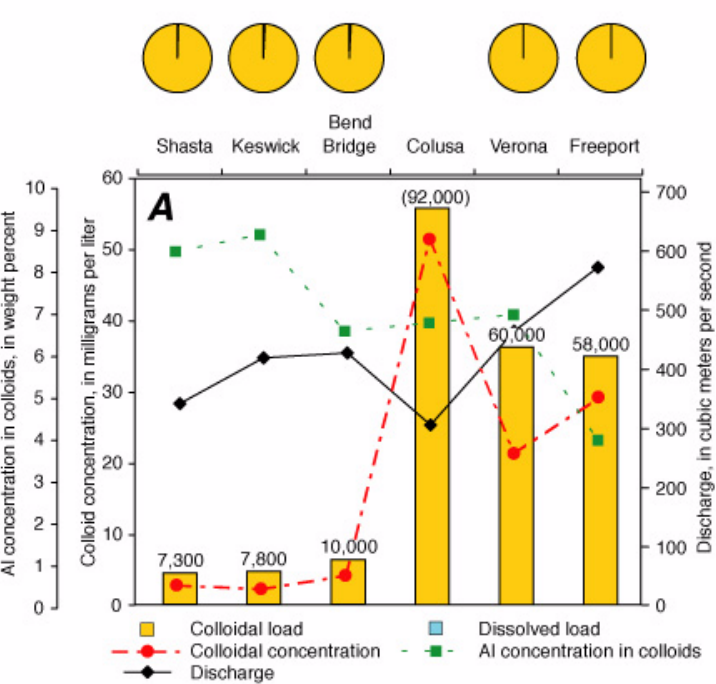

December 1996

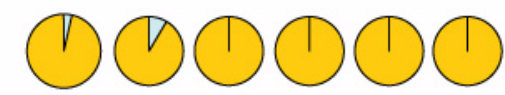

Bend

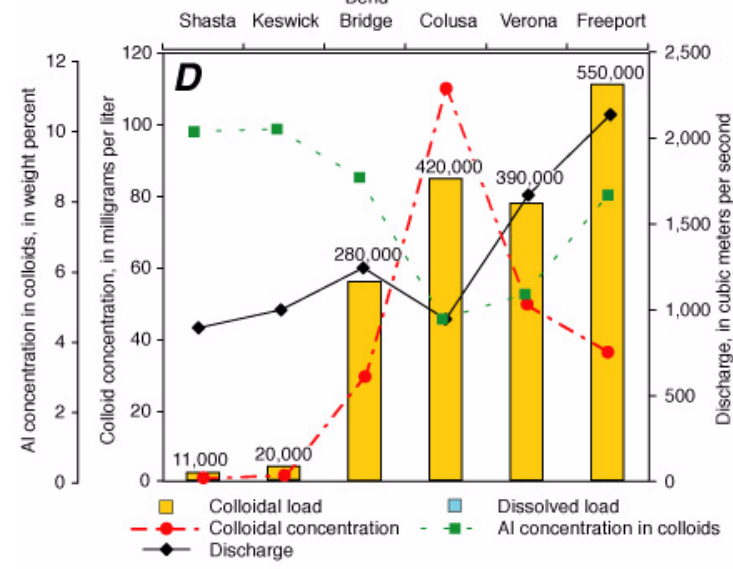

September 1996

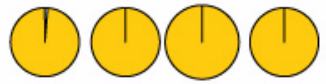

Shasta Keswick Bridge Colusa Verona Freepor

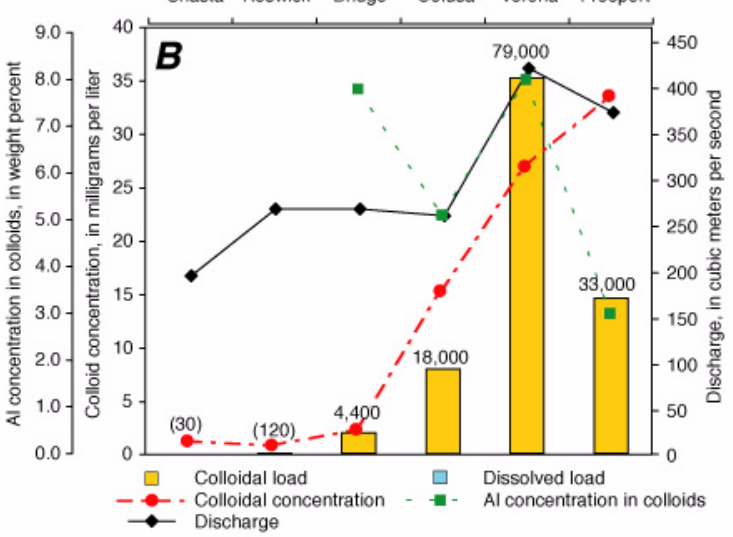

January 1997

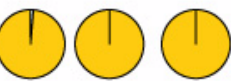

Bend
Shasta Keswick Bridge Colusa Verona $\begin{gathered}\text { Tower Bridge } \\ \text { plus Yolo }\end{gathered}$ Bypass

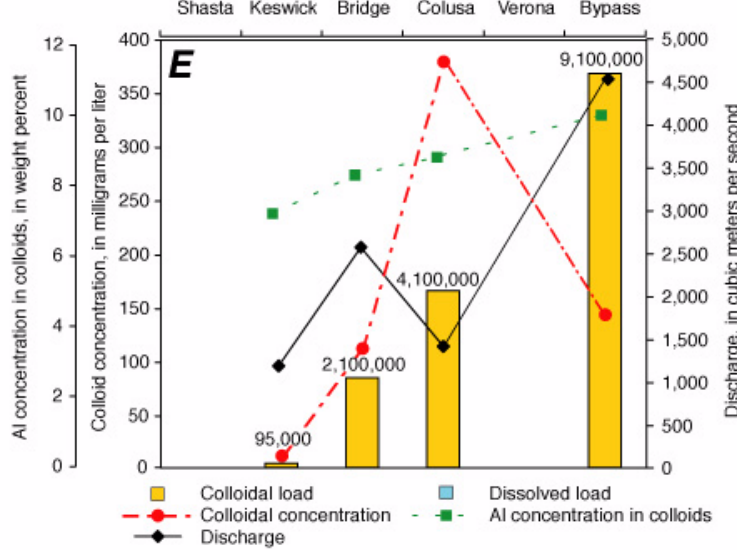

November 1996
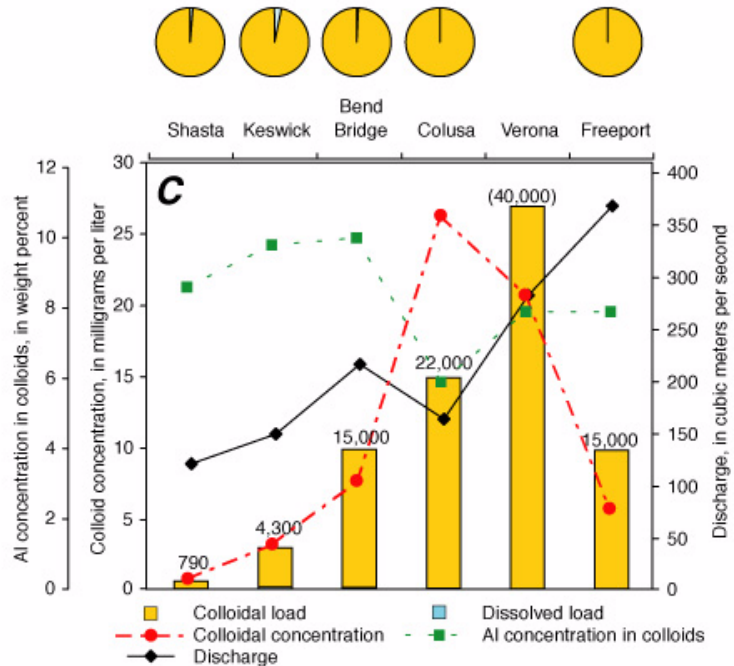

May-June 1997

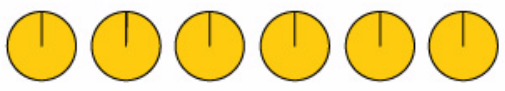

Shasta Keswick Bridge

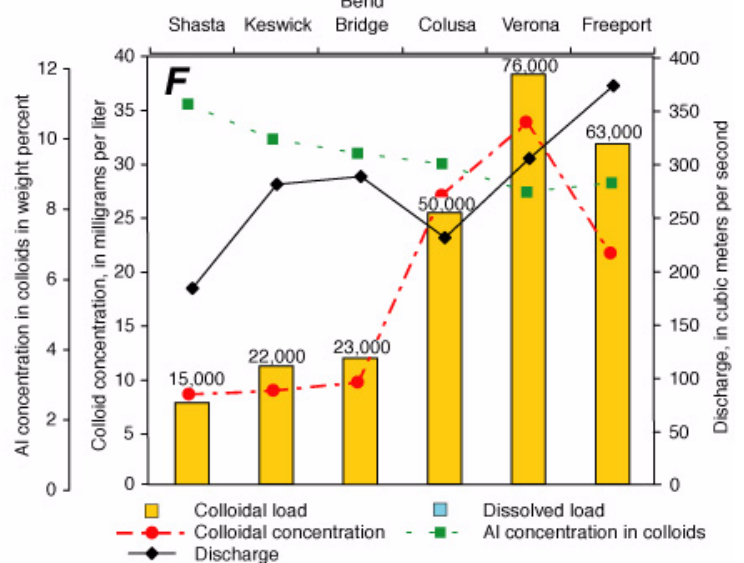

Figure 10. Plots of dissolved and colloidal aluminum loads, colloid concentration, aluminum concentration in colloids, and discharge, Sacramento River, California for A. July 1996, B. September 1996, C. November 1996, D. December 1996, E. January 1997, and F. May-June 1997. Color scheme: blue, dissolved; yellow, colloidal. Bars represent dissolved and colloidal loads (missing bars indicate that either no sample was taken or that no data are available.) Sums of dissolved and colloidal loads, in kilograms per day, are given at tops of bars (parentheses around numbers indicate colloidal load where no dissolved data are available). Pie charts represent proportions of dissolved and colloidal loads. "Colloid concentration" represents the amount of colloids in water, in milligrams per liter. "Al concentration in colloids" represents the aluminum concentration in the colloids, in weight percent (dry weight). Note: In some cases, vertical scales are not the same for all sampling periods. 


\section{Cadmium loads}

July 1996

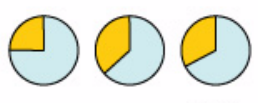

Shasta Keswick Bridge Colusa Verona Freeport

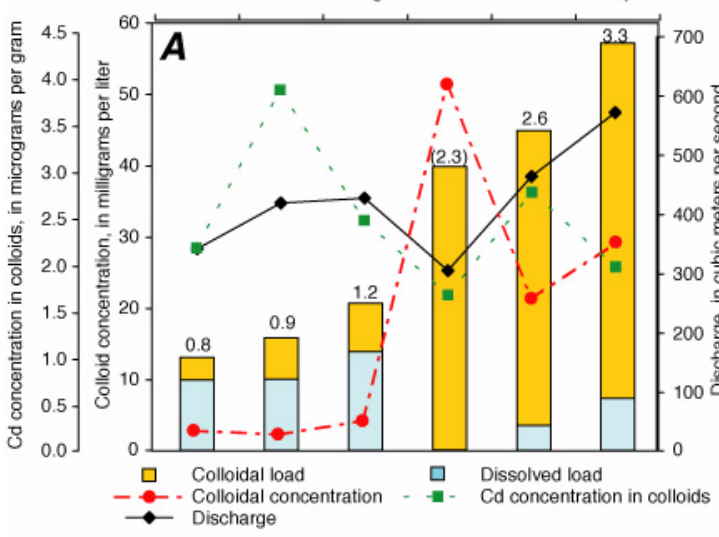

December 1996

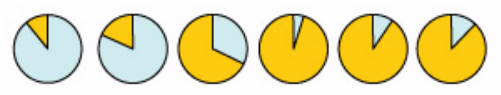

Shasta Keswick Bridge Colusa Verona Freeport

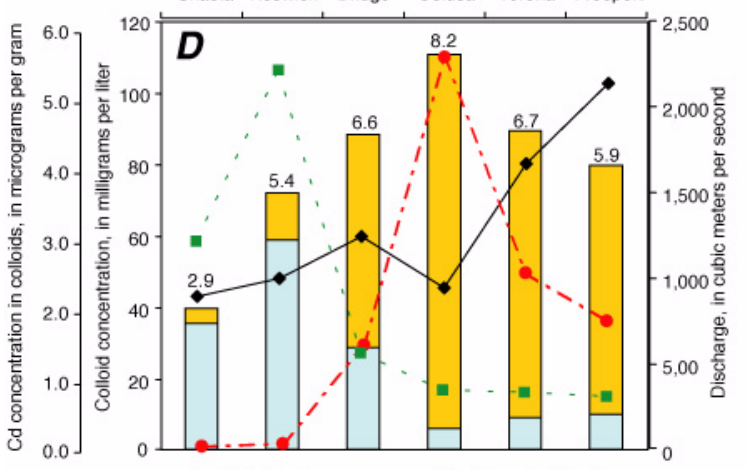

Colloidal load
-- Colloidal conc
- Discharge
$-$
Cd concentration in colloids

\section{September 1996}

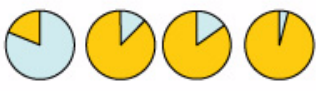

Shasta Keswick Bridge Colusa Verona Freeport

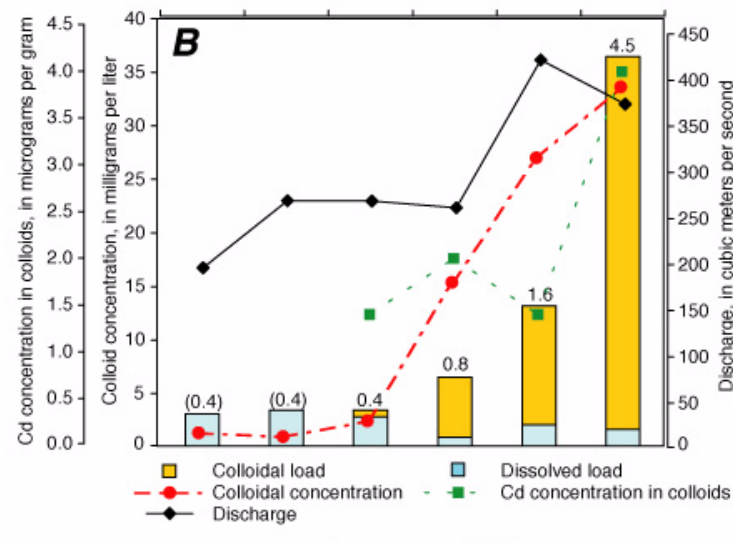

January 1997

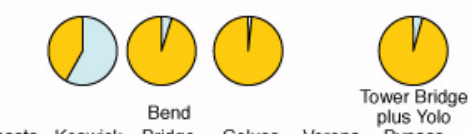

Shasta Keswick Bridge Colusa Verona pypass

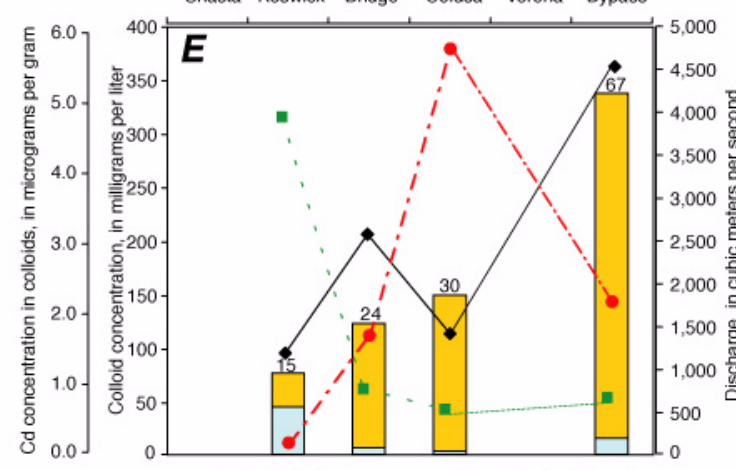

Colloidal load
-- Colloidal con
- Discharge
Dissolved load
Cd concentration in colloids

\section{November 1996}

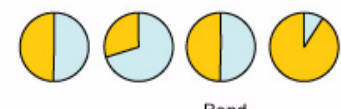

Bend

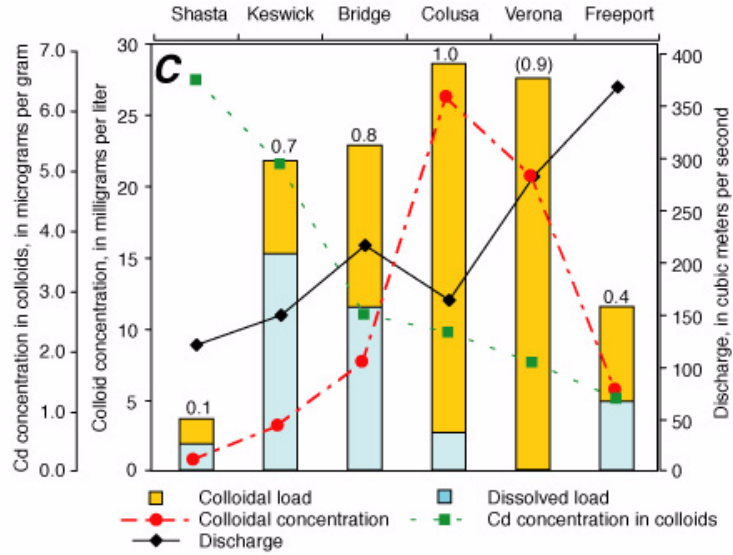

May-June 1997
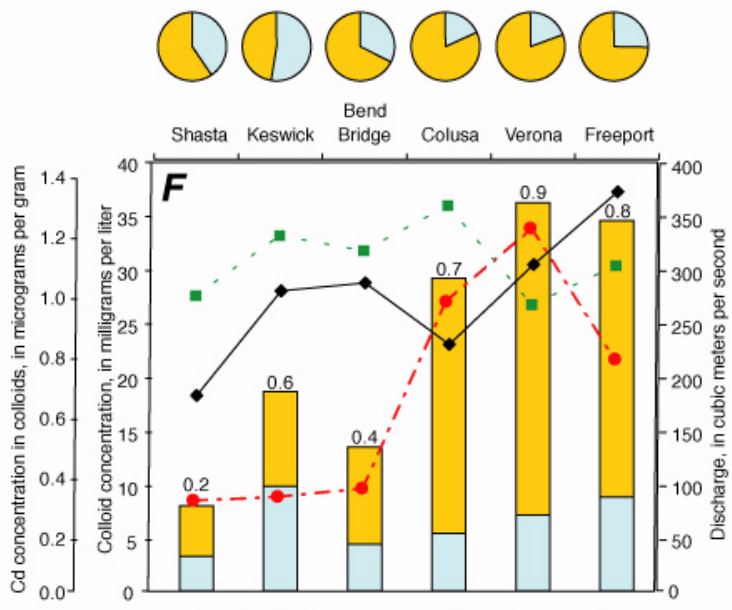

Colloidal load Discharge

Figure 11. Plots of dissolved and colloidal cadmium loads, colloid concentration, cadmium concentration in colloids, and discharge, Sacramento River, California for A. July 1996, B. September 1996, C. November 1996, D. December 1996, E. January 1997, and F. May-June 1997. Color scheme: blue, dissolved; yellow, colloidal. Bars represent dissolved and colloidal loads (missing bars indicate that either no sample was taken or that no data are available.) Sums of dissolved and colloidal loads, in kilograms per day, are given at tops of bars (parentheses around numbers indicate colloidal load where no dissolved data are available). Pie charts represent proportions of dissolved and colloidal loads. "Colloid concentration" represents the amount of colloids in water, in milligrams per liter. "Cd concentration in colloids" represents the cadmium concentration in the colloids, in micrograms per gram (dry weight). Note: In some cases, vertical scales are not the same for all sampling periods. 


\section{Copper loads}

ก

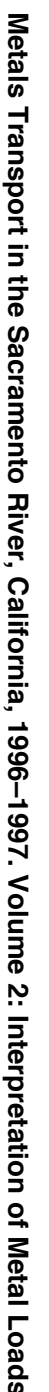

July 1996

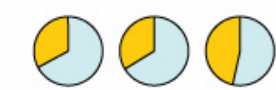

$O O$

Bridge Colusa Verona Freeport

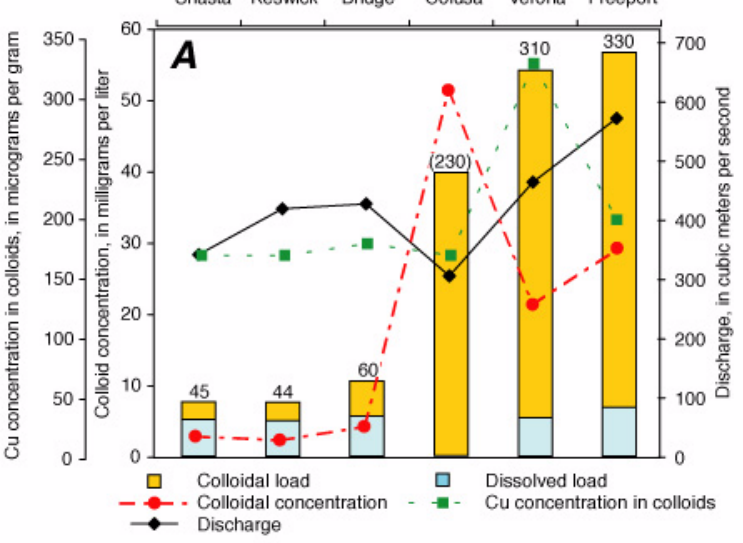

December 1996
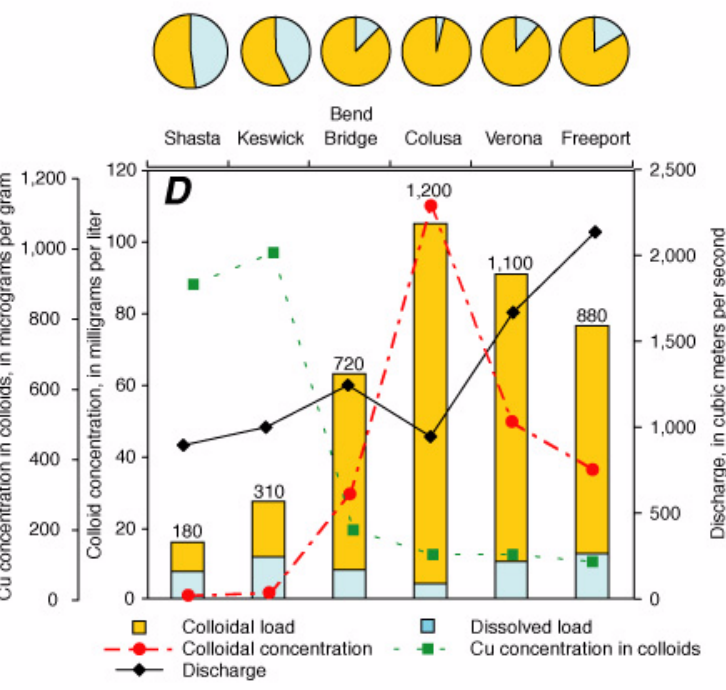

September 1996

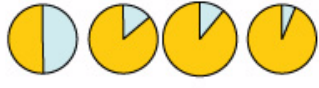

Shasta Keswick Bridge Colusa Verona Freeport

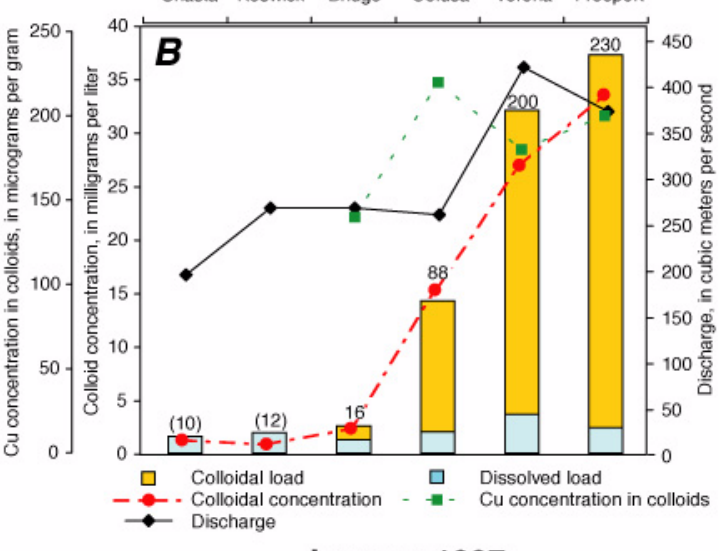

January 1997

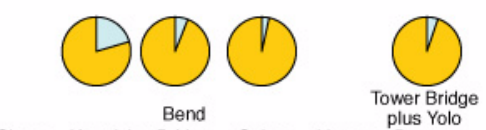

Shasta Keswick Bridge Colusa Verona $\begin{gathered}\text { Bend } \\ \text { Bypass }\end{gathered}$

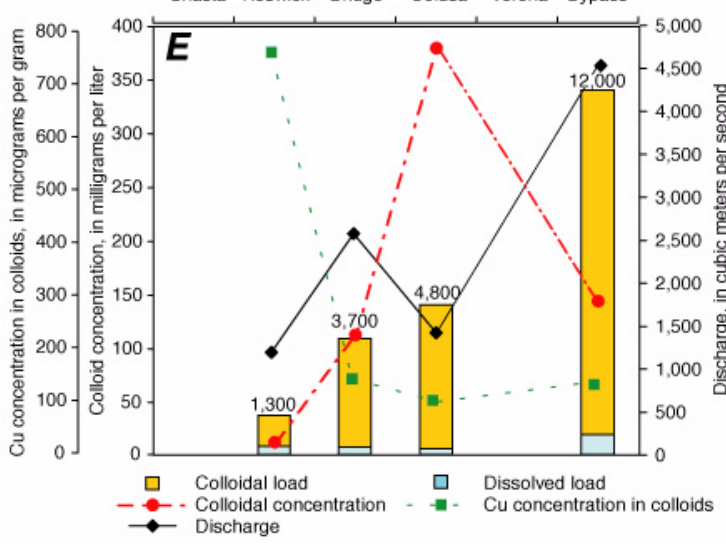

November 1996

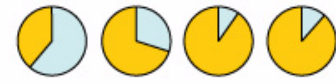

Shasta Keswick Bridge Colusa Verona Freeport

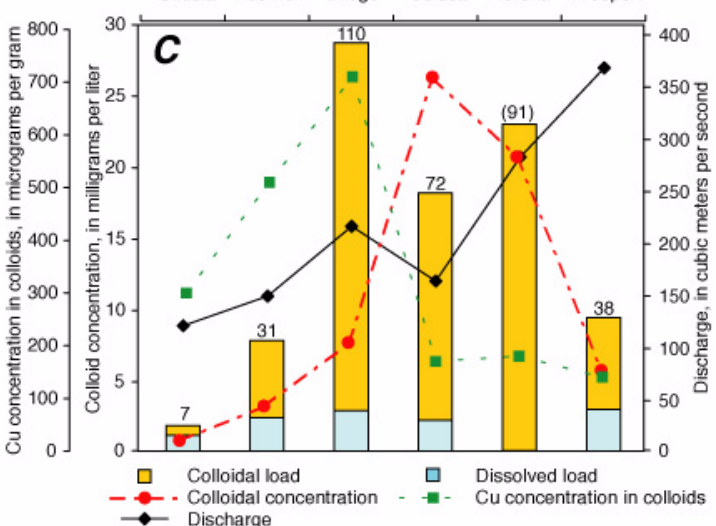

May-June 1997
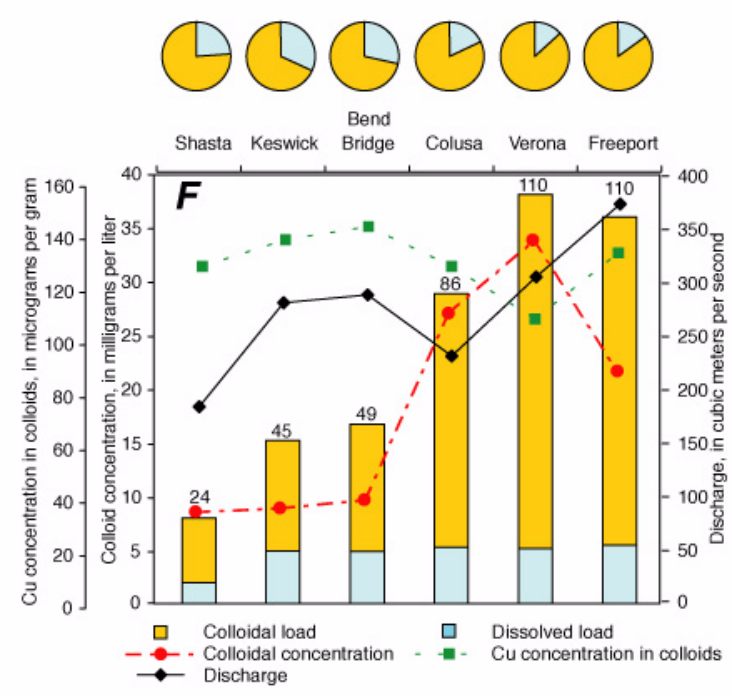

Figure 12. Plots of dissolved and colloidal copper loads, colloid concentration, copper concentration in colloids, and discharge, Sacramento River, California for A. July 1996, B. September 1996, C. November 1996, D. December 1996, E. January 1997, and F. May-June 1997. Color scheme: blue, dissolved; yellow, colloidal. Bars represent dissolved and colloidal loads (missing bars indicate that either no sample was taken or that no data are available.) Sums of dissolved and colloidal loads, in kilograms per day, are given at tops of bars (parentheses around numbers indicate colloidal load where no dissolved data are available). Pie charts represent proportions of dissolved and colloidal loads. "Colloid concentration" represents the amount of colloids in water, in milligrams per liter. "Cu concentration in colloids" represents the copper concentration in the colloids, in micrograms per gram (dry weight). Note: In some cases, vertical scales are not the same for all sampling periods. 


\section{Iron loads}

July 1996

September 1996

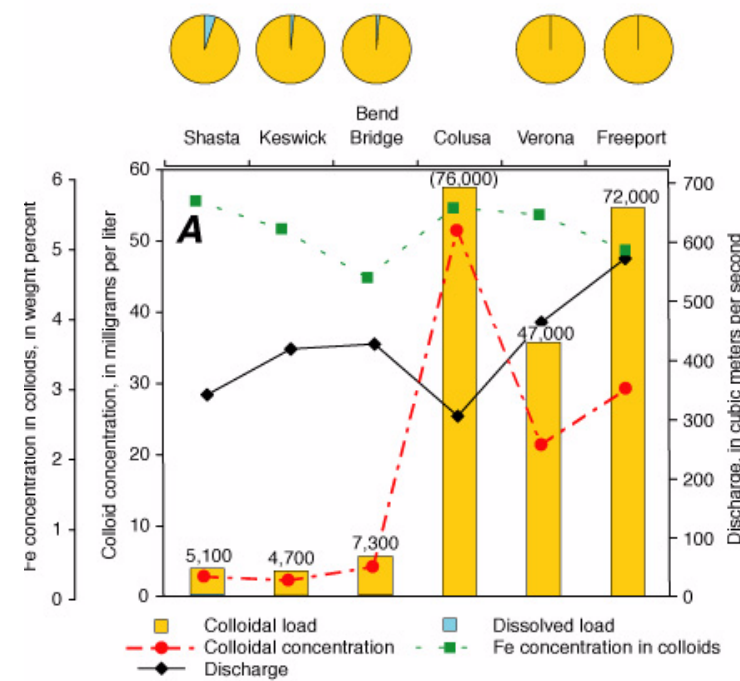

December 1996

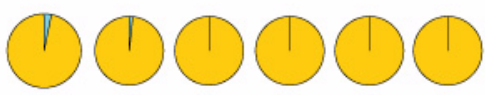

Bend

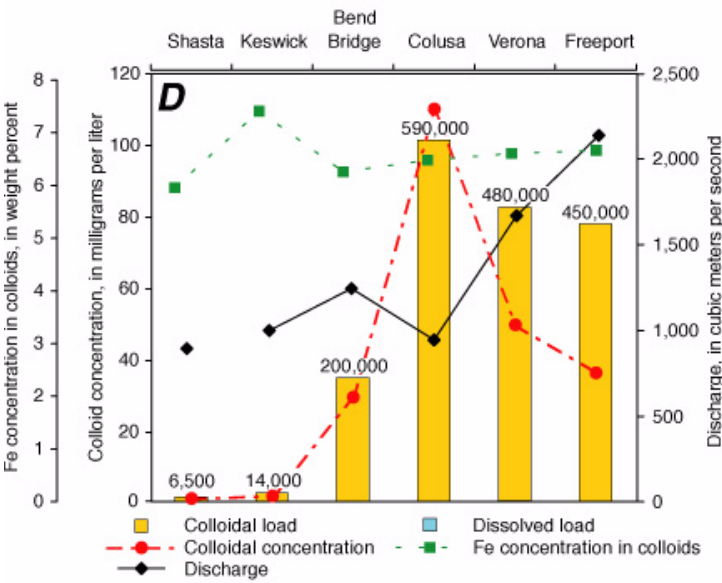

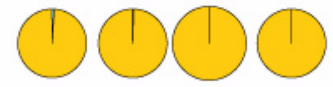

Shasta Keswick Bridge Colusa Verona Freepo

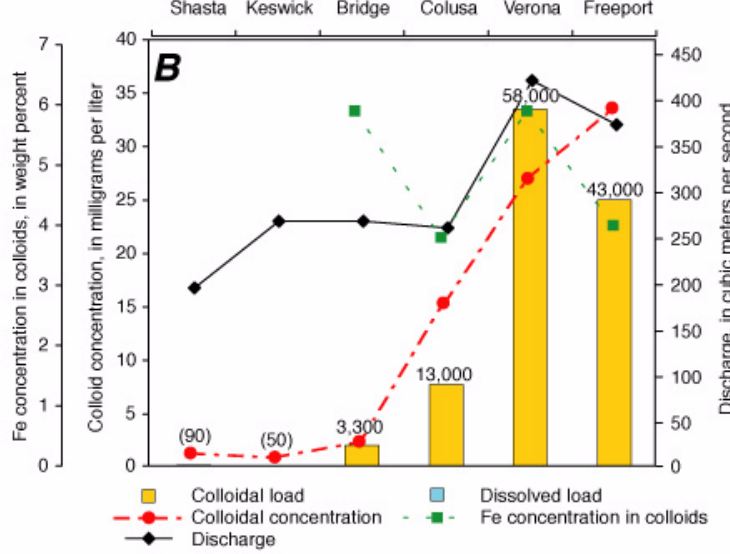

January 1997

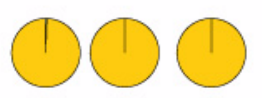

Shasta Keswick Bridge colusa verona $\begin{gathered}\text { Tower Bridge } \\ \text { plus Yolo } \\ \text { Bypass }\end{gathered}$

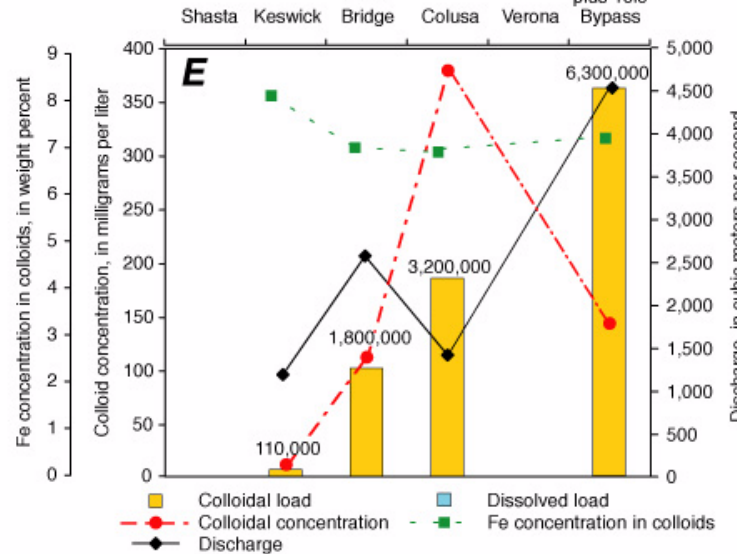

November 1996

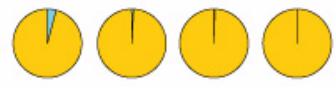

Shasta Keswick Bridge Colusa Verona Froopos

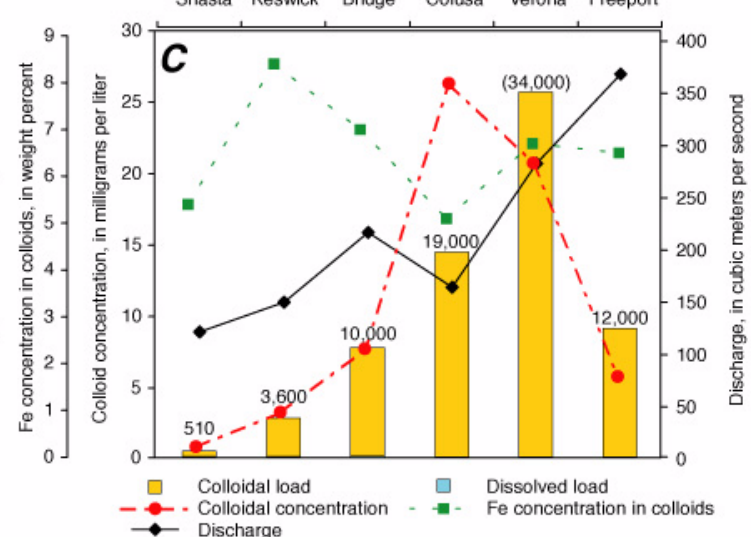

May-June 1997

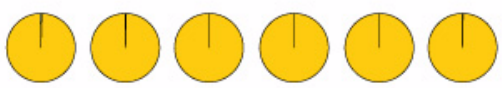

Shasta Keswick Bridge Colusa Verona Freeport

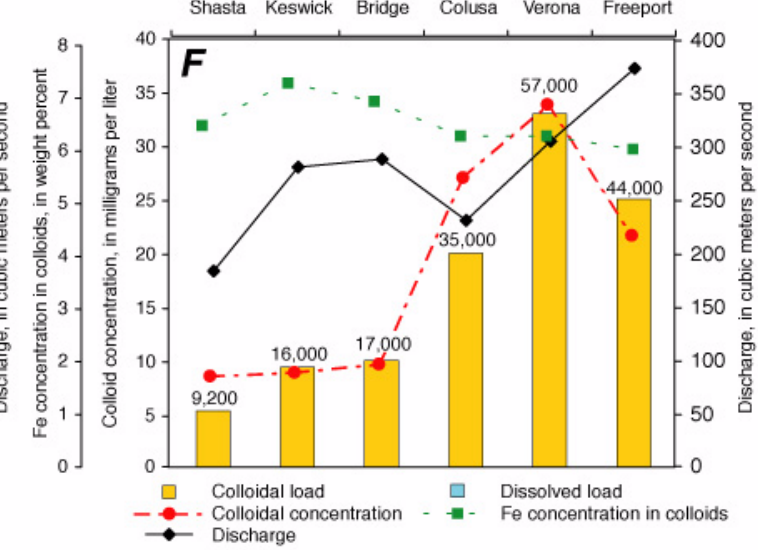

Figure 13. Plots of dissolved and colloidal iron loads, colloid concentration, iron concentration in colloids, and discharge, Sacramento River, California for $A$. July 1996, B. September 1996, C. November 1996, D. December 1996, E. January 1997, and F. May-June 1997. Color scheme: blue, dissolved; yellow, colloidal. Bars represent dissolved and colloidal loads (missing bars indicate that either no sample was taken or that no data are available.) Sums of dissolved and colloidal loads, in kilograms per day, are given at tops of bars (parentheses around numbers indicate colloidal load where no dissolved data are available) based on dissolved concentration below detection limit). Pie charts represent proportions of dissolved and colloidal loads. "Colloid concentration" represents the amount of colloids in water, in milligrams per liter. "Fe concentration in colloids" represents the iron concentration in the colloids, in weight percent (dry weight). Note: In some cases, vertical scales are not the same for all sampling periods. 


\section{Lead loads}

July 1996

September 1996

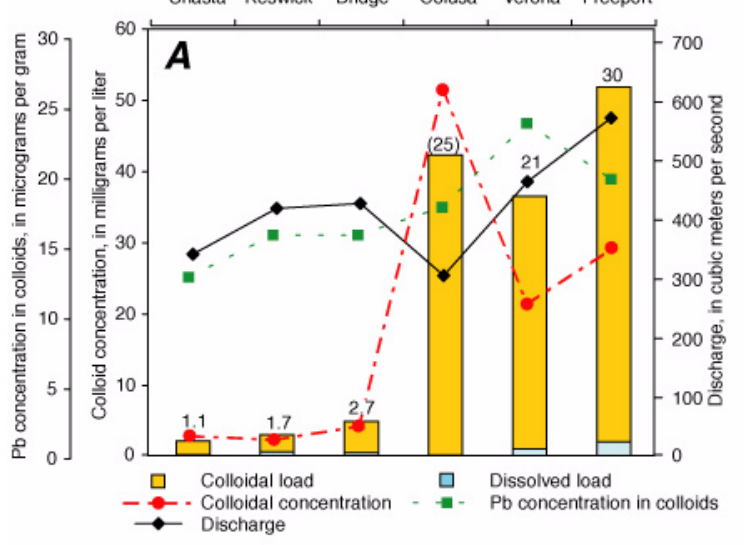

December 1996
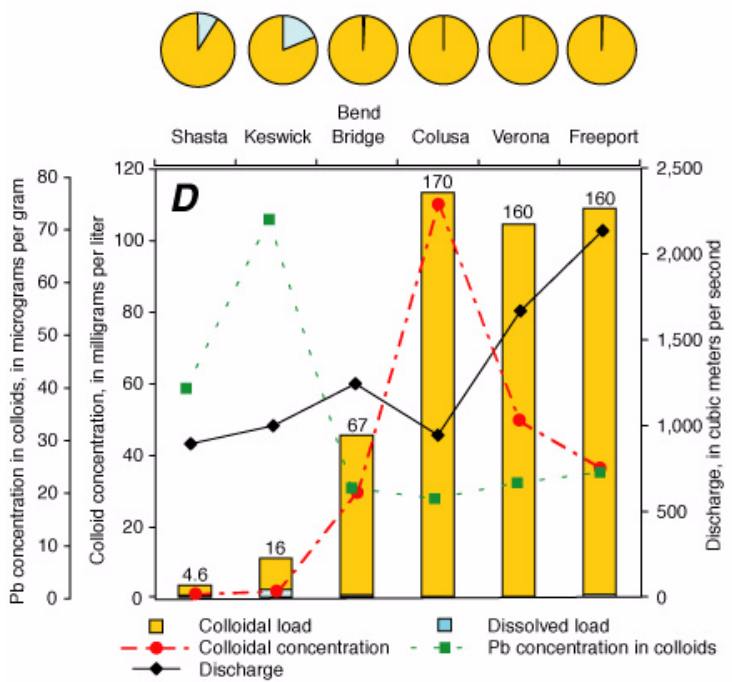

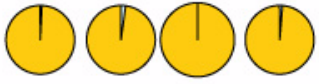

Shasta Keswick Bridge Colusa Verona Freeport

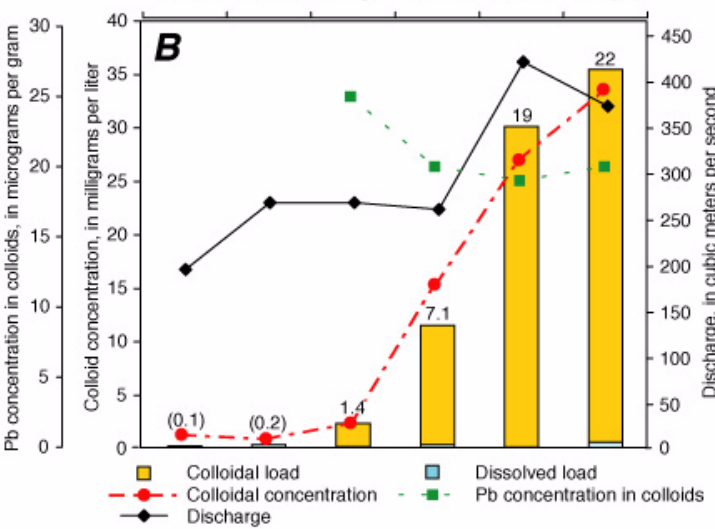

January 1997

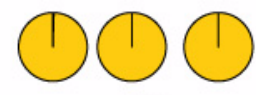

Bend
Tower Bridge
plus Yolo

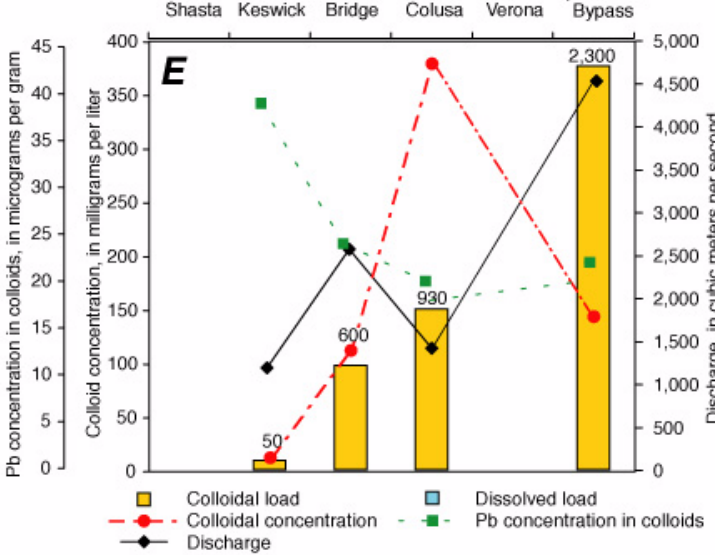

November 1996

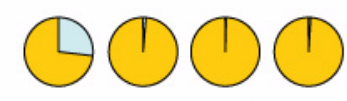

Shasta Keswick Bridge Colusa Verona Freeport

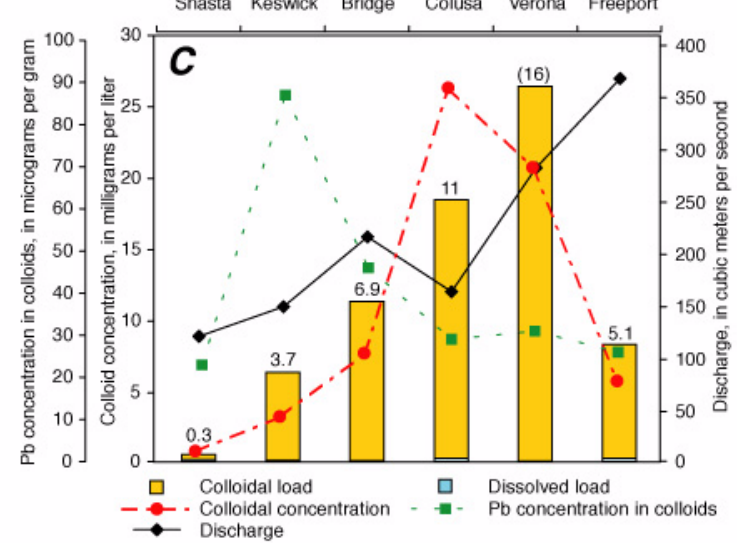

May-June 1997

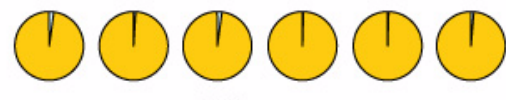

Bend

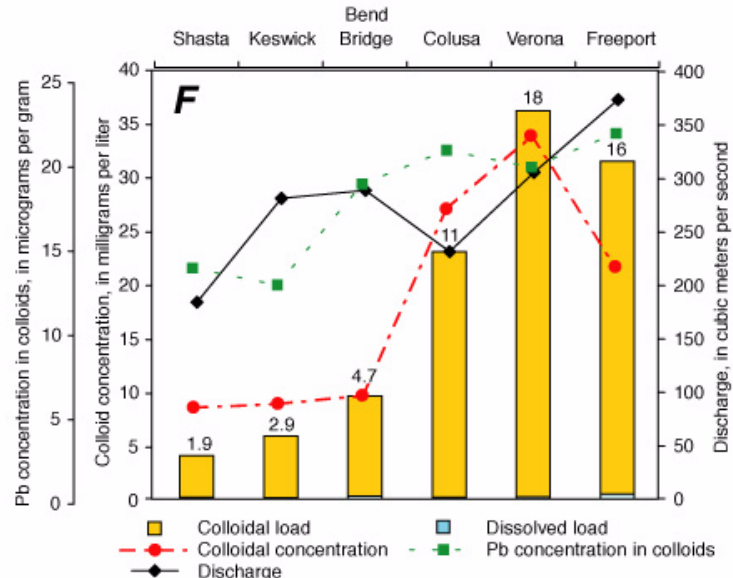

Figure 14. Plots of dissolved and colloidal lead loads, colloid concentration, lead concentration in colloids, and discharge, Sacramento River, California for $A$. July 1996, B. September 1996, C. November 1996, D. December 1996, E. January 1997, and F. May-June 1997. Color scheme: blue, dissolved: yellow, colloidal. Bars represent dissolved and colloidal loads (missing bars indicate that either no sample was taken or that no data are available.) Sums of dissolved and colloidal loads, in kilograms per day, are given at tops of bars (parentheses around numbers indicate colloidal load where no dissolved data are available). Pie charts represent proportions of dissolved and colloidal loads. "Colloid concentration" represents the amount of colloids in water, in milligrams per liter. "Pb concentration in colloids" represents the lead concentration in the colloids, in micrograms per gram (dry weight). Note: In some cases, vertical scales are not the same for all sampling periods. 


\section{Zinc loads}

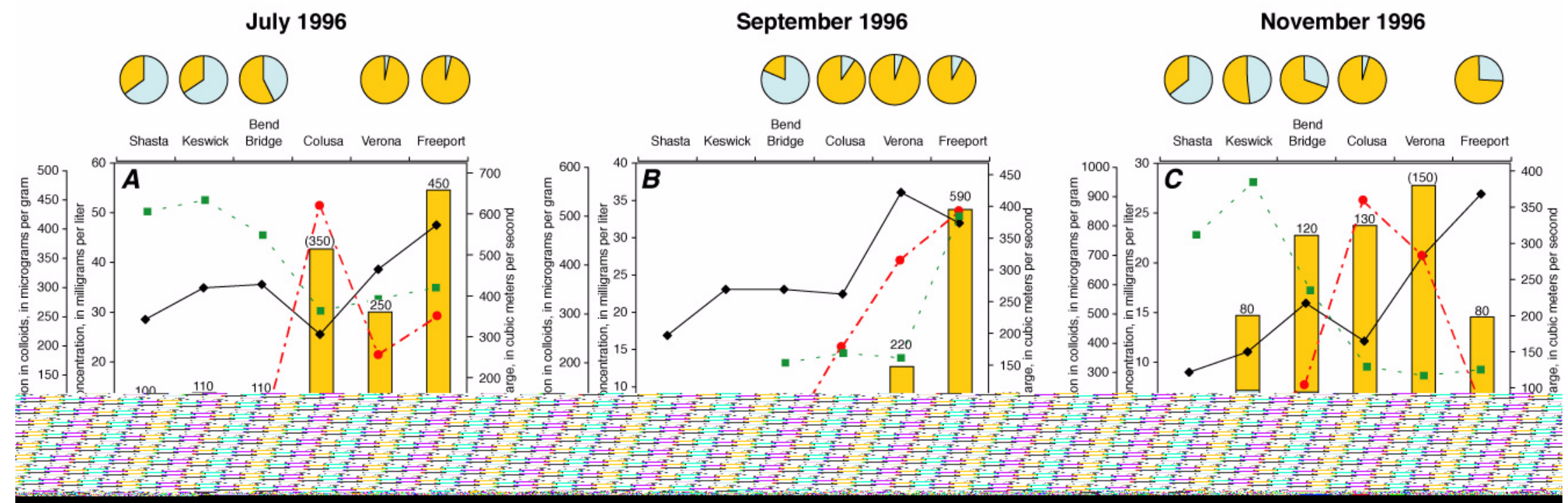

Figure 15. Plots of dissolved and colloidal zinc loads, colloid concentration, lead concentration in colloids, and discharge, Sacramento River, California for A. July 1996, B. September 1996, C. November 1996, D. December 1996, E. January 1997, and F. May-June 1997. Color scheme: blue, dissolved; yellow, colloidal. Bars represent dissolved and colloidal loads (missing bars indicate that either no sample was taken or that no data are available.) Sums of dissolved and colloidal loads, in kilograms per day, are given at tops of bars (parentheses around numbers indicate colloidal load where no dissolved data are available). Pie charts represent proportions of dissolved and colloidal loads. "Colloid concentration" represents the amount of colloids in water, in milligrams per liter. "Zn concentration in colloids" represents the zinc concentration in the colloids, in micrograms per gram (dry weight). Note: In some cases, vertical scales are not the same for all sampling periods. 
equivalent concentrations of the colloids plus the dissolved concentrations were shown to have strong positive correlations for most constituents (Alpers and others, 2000). Because constituent loads are directly proportional to concentrations, the correlations of total-recoverable loads with the sum of colloidal and dissolved loads are identical to the correlations among similar concentrations. Thus, in general, total recoverable (whole-water) loads correlate well with the sum of the dissolved and colloidal loads discussed above.

However, there are three probable causes for those cases where there are systematic differences between the total recoverable (whole-water) loads and the sum of the colloidal and dissolved loads. First, the colloid material was obtained from larger samples that were probably more representative of the river than the smaller samples collected for whole-water determinations. The whole-water samples were $250 \mathrm{~mL}$ subsamples taken from 8 to $15 \mathrm{~L}$ of water collected in churns, whereas samples collected for the isolation of colloidal material generally were 50 to $100 \mathrm{~L}$ of river water per sample. Second, the total recoverable digestion procedure on whole-water samples is a partial digestion involving a hydrochloric acid $(\mathrm{HCl})$ extraction that followed field preservation with nitric acid $\left(\mathrm{HNO}_{3}\right)$, a procedure that does not completely dissolve recalcitrant minerals. In contrast, the colloidal material was completely decomposed using an $\mathrm{HCl}-\mathrm{HNO}_{3}-\mathrm{HF}$ (HF is hydrofluoric acid) total digestion procedure (Alpers and others, 2000). Finally, the whole-water samples may have contained both silt- and sand-sized material in addition to colloidal material, because they were subsampled prior to size separation. Sand and silt would be (at most) minor components of the colloidal samples because the $25-\mathrm{L}$ carboys containing the colloid samples were allowed to settle at least one hour prior to sample filtration.

\section{Colloid Speciation Data}

There were three sampling periods for which metals speciation data from colloids were collected using sequential extraction techniques: December 1996, January 1997, and May-June 1997. The sequential extractions consisted first of a chemical reduction step with $\mathrm{HCl}$-acidified hydroxylamine hydrochloride designed to remove metals weakly bound to the sediment and those associated with iron or manganese oxide coatings. This fraction is referred to as the "reducible phase." The residue from this extraction was treated with a potassium persulfate solution to oxidize any organic coatings or organic particles. This fraction is referred to as the "oxidizable phase." Finally, an $\mathrm{HCl}-\mathrm{HNO}_{3}-\mathrm{HF}$ acid microwave digestion, identical to that used for total digestions, was performed on the residue from the oxidizable phase extraction. This fraction is termed the "residual phase."

The speciated loads of cadmium, copper, lead, and zinc based on sequential extraction of colloid concentrates are represented graphically in figures 16 $(A-D), 17(A-D)$, and $18(A-D)$ for December 1996, January 1997, and May-June 1997, respectively. Each figure has two sets of pie charts and a map of the Sacramento River area; the set in red and blue displays the relative proportion of dissolved and colloidal loads to the total load, similar to the pie charts in figures 10 through 15 . However, the pie charts in figures 16 through 18 differ from those in figures 10 through 15 in that the areas of the pies in figures 16 through 18 are proportional to the constituent load at each site, and they show available data from tributaries.

The second set of pie charts colored orange, green, and yellow on figures 16 through 18 represent the proportions of the constituent colloidal load that were associated with reducible, oxidizable, and residual phases, as just described. Similar to the red and blue pie charts showing dissolved and colloidal loads, the areas of the pies showing colloidal speciation are proportional to the total colloidal loads. These plots show how the various forms of the metals change with downstream transport, both proportionally and in absolute quantity. The trends on these graphs are discussed in later sections of this report.

\section{Uncertainties in Metal Loads}

Uncertainties in metal-load data consist of a combination of uncertainties from the concentration data and the discharge data that are multiplied together to compute the loads. Uncertainties in concentration data arise from variations in both accuracy and precision. The accuracy of trace element data in this study was determined using frequent analysis of standard reference materials (SRM) and spike recoveries, both of which show accuracy consistent with the project's data quality objectives (Alpers and others, 2000). Replicate laboratory determinations were used to 
estimate analytical precision. For analyses in concentration ranges greater than ten times the detection limit, variability in precision generally was less than 5 percent of the amount present. In the concentration range less than ten times the detection limit, deter-minations are less precise and, therefore, the uncertainties are greater. In this study, with regard to the metals of principal concern $(\mathrm{Al}, \mathrm{Cd}, \mathrm{Cu}, \mathrm{Fe}, \mathrm{Pb}$, and $\mathrm{Zn}$ ) the detection limit was important only for dissolved samples, that is the ultrafiltrates that passed through 10,000 NMWL tangential-flow ultrafilters (equivalent to $0.005-\mu \mathrm{m}$ pore-size diameter).

Dissolved aluminum, cadmium, iron, and lead concentrations at some localities were near the detection limits; therefore, the analytical uncertainties associated with dissolved loads for these constituents are relatively high, perhaps as high as 50 percent. Dissolved copper and zinc concentrations were generally greater than ten times the detection limits, so the analytical uncertainties associated with dissolved copper and zinc concentrations are much lower, probably in the range of 3 to 5 percent. This variance does not take into account the potential problems related to the collection of a representative field sample. The estimation of the magnitude of that variability is beyond the scope of this study.

Colloids were freeze dried and digested prior to analysis. Analytical uncertainties in colloid analyses come from the digestion methods and the fact that aluminum analyses were used as a basis for converting the solid concentrations to equivalent colloid concentrations (Alpers and others, 2000). On the basis of precision data from replicate analyses, it is estimated that the analytical uncertainty on colloid analyses is about 5 percent for most elements, which is consistent with the reporting of most concentration data to two decimal places.

The other major component of uncertainty in the calculated metal loads is the uncertainty in stream discharge data. Most samples were collected at, or close to, stream gaging stations operated by the USGS. River stage (elevation of the water surface) is continuously recorded at each gage, and instantaneous discharge measurements are made at the site during the year, including critical times of very high or very low flows. These instantaneous measurements of gage height and discharge are used to determine a stagedischarge relationship (rating) for each station. The rating is used with the continuous gage height record to develop a continuous record of discharge. The accuracy of discharge records at these sites is dependent on the stability of the stage-discharge relation and the accuracy of instantaneous measurements of stage and discharge used to develop the rating. The daily mean discharges from gaged sites used in this report are considered accurate to within 10 percent of the discharge 95 percent of the time (Rockwell and others, 1998).

The Colusa Basin Drain site was not gaged, so discharge was measured at the time of sample collection using current meter methods described by Rantz and others (1982). Considering the channel characteristics of this site, measurements are typically accurate to within 5 percent of the measured flow (Sauer and Meyer, 1992).

Discharge measurements for the Sacramento River below Shasta Dam and below Keswick Dam were determined from outflow records for Shasta and Keswick dams. Release rates from Shasta Dam, Keswick Dam, and the Spring Creek Power Plant (SCPP) were provided by the Bureau of Reclamation. Accuracy of the data from Shasta Dam, Keswick Dam, and the SCPP is believed to be within 2 percent of the recorded values (Valerie Ungvari, Bureau of Reclamation, oral commun., November 17, 1999). Discharge from the Spring Creek arm of Keswick Reservoir was determined by adding flows released from the SCPP and flows from the gaging station on Spring Creek. Uncertainty is likely between 2 and 10 percent, depending on relative flows from the two sources.

Combining the information about uncertainty from the concentration and discharge data, the minimum uncertainty is 10 to 15 percent, with approximately half of the uncertainty from concentration measurements and half from the discharge estimates. This would be consistent with reporting all metal loads to one significant figure. This minimum uncertainty relates to the accuracy of the loads. Because the precision of the loads is considered better than the accuracy, loads are presented in this report with two significant figures so that relative comparisons can be made.

\section{Discussion of Spatial and Temporal Variations in Metal Loads}

The observations that follow focus mainly on four trace elements: cadmium, copper, lead, and zinc. In addition, variations in iron and aluminum loads are described; these two elements are major components 


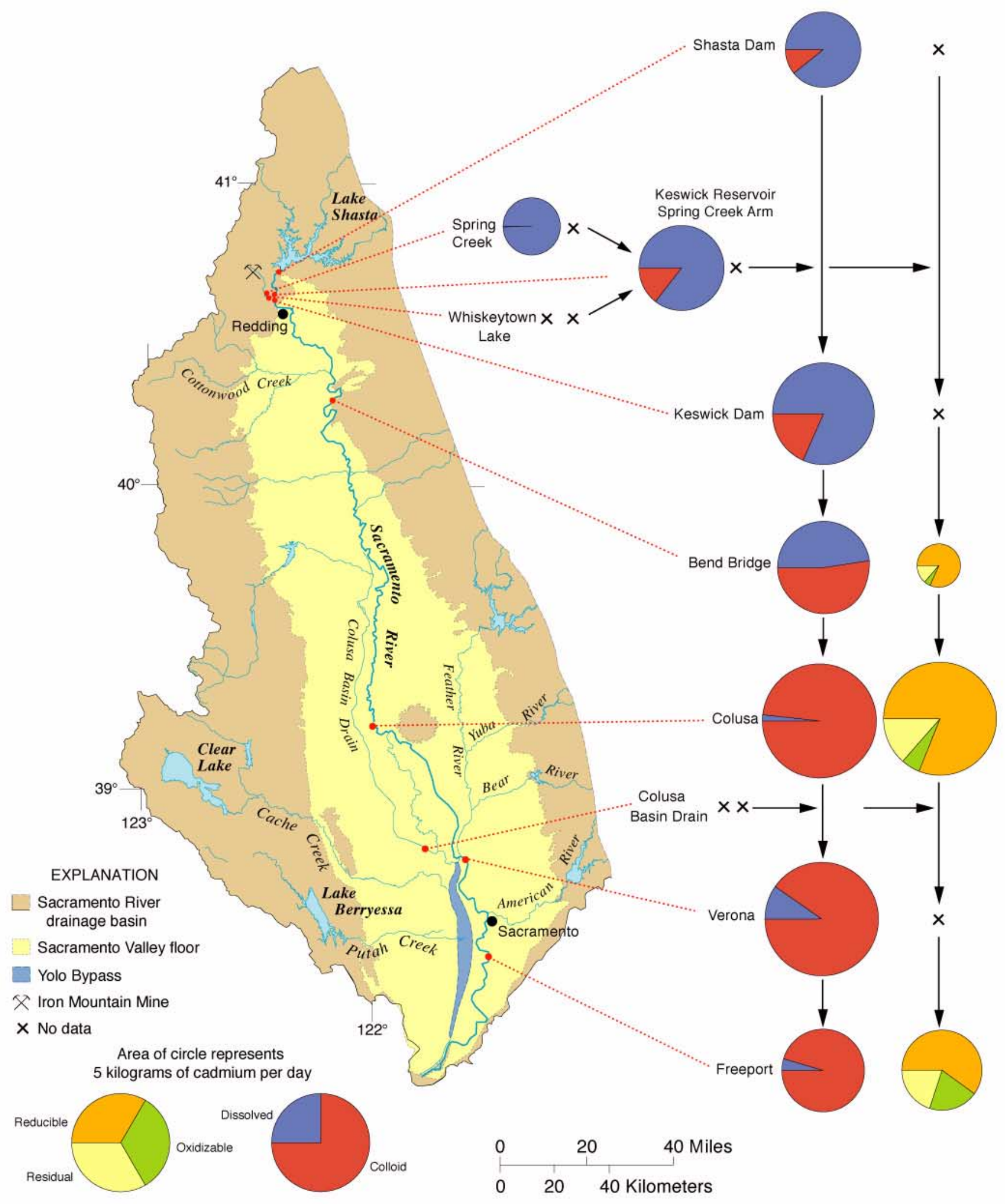

Figure 16A. Distribution and speciation of colloidal cadmium loads during December 1996, Sacramento River, California, and selected tributaries. 


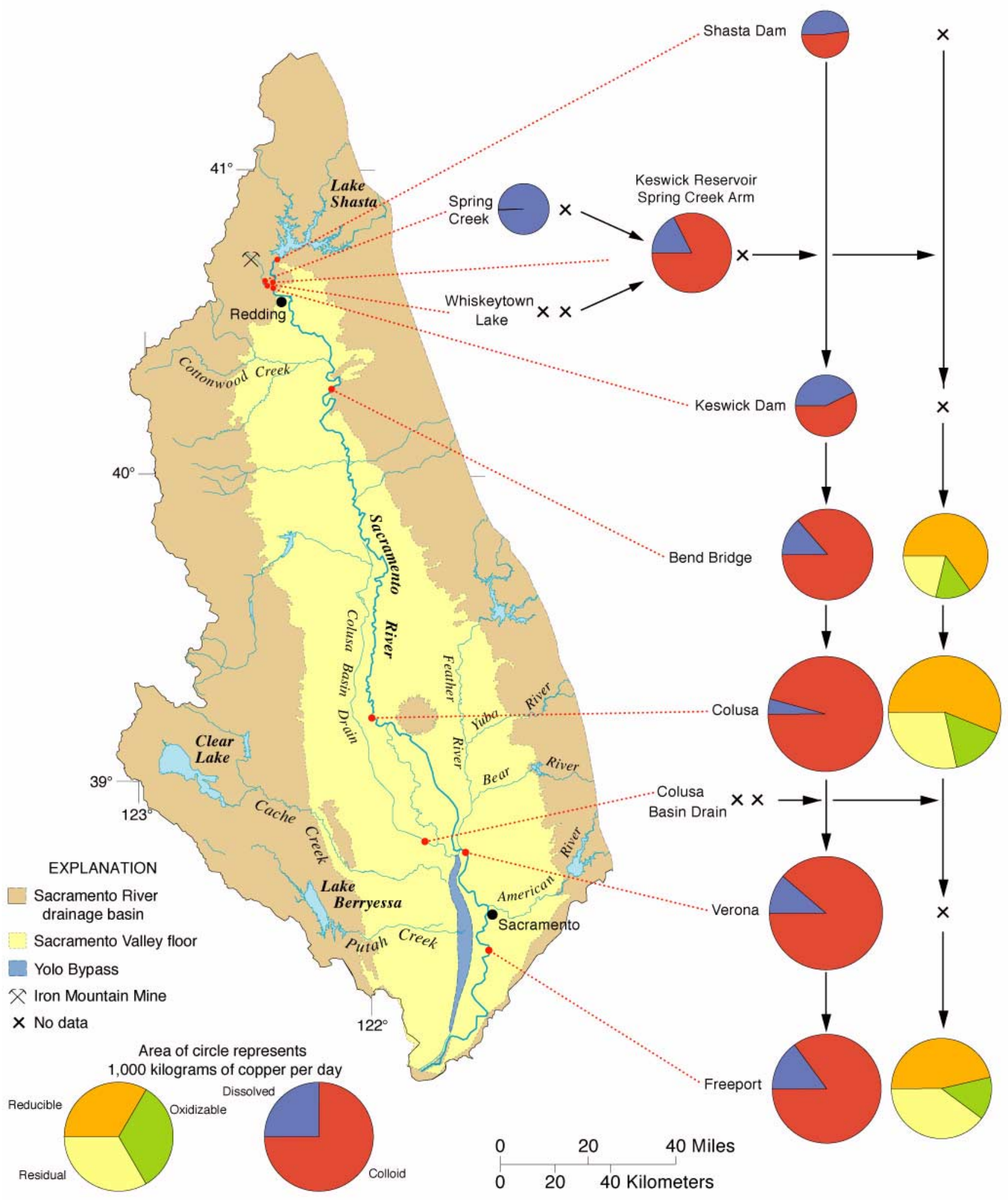

Figure 16B. Distribution and speciation of colloidal copper loads during December 1996, Sacramento River, California, and selected tributaries. 


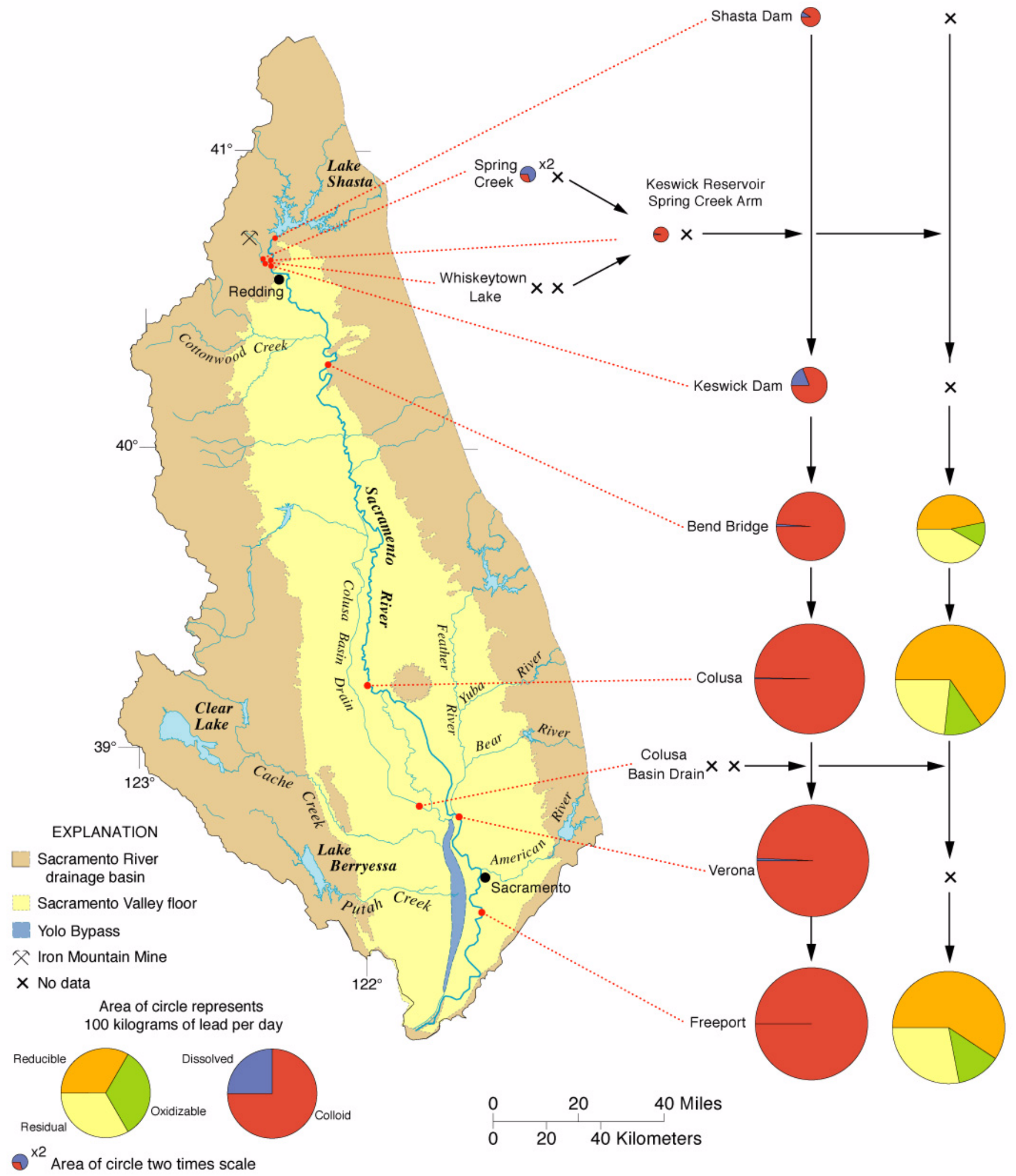

Figure 16C. Distribution and speciation of colloidal lead loads during December 1996, Sacramento River, California, and selected tributaries. 


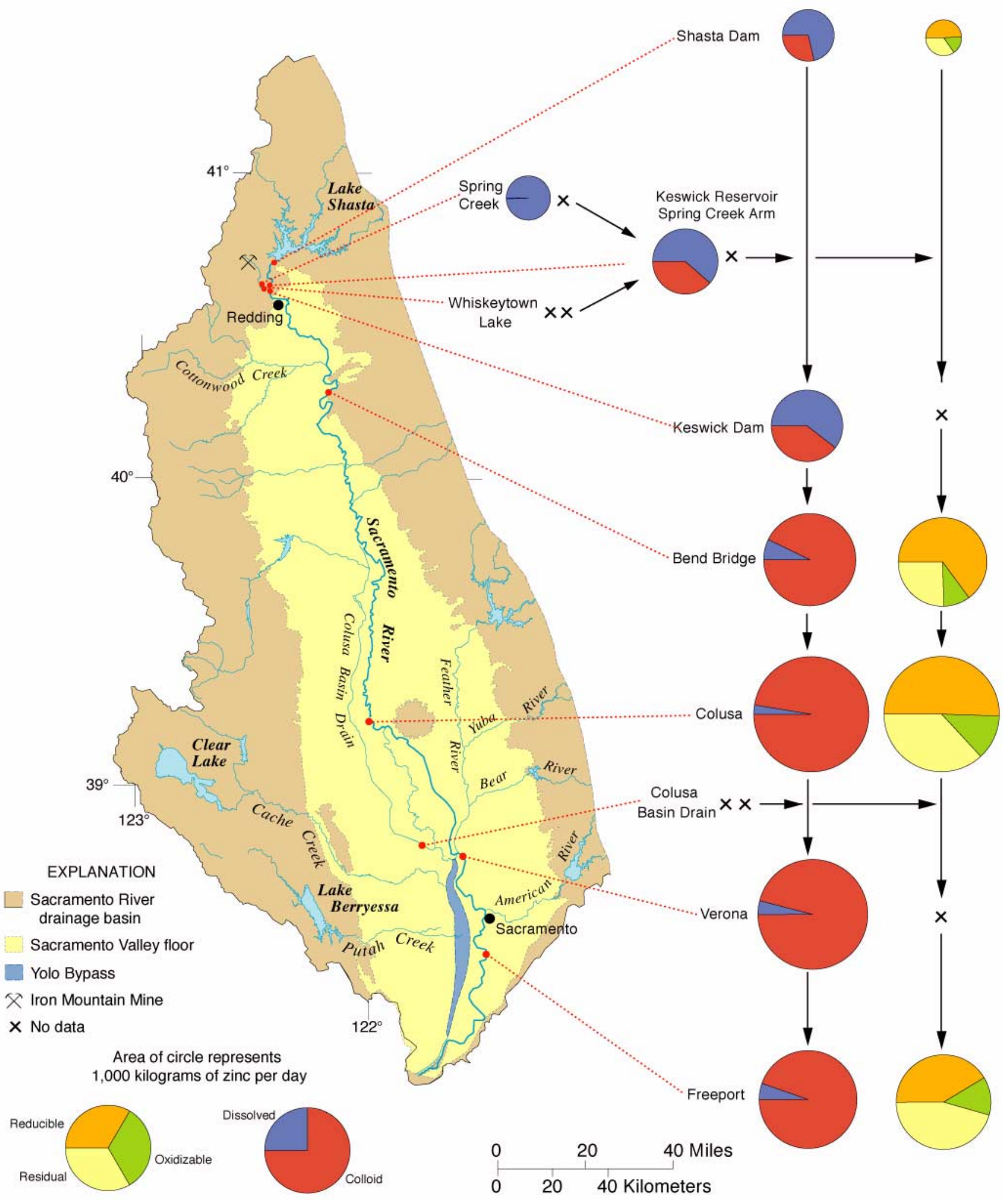

Figure 16D. Distribution and speciation of colloidal zinc loads during December 1996, Sacramento River, California, and selected tributaries. 


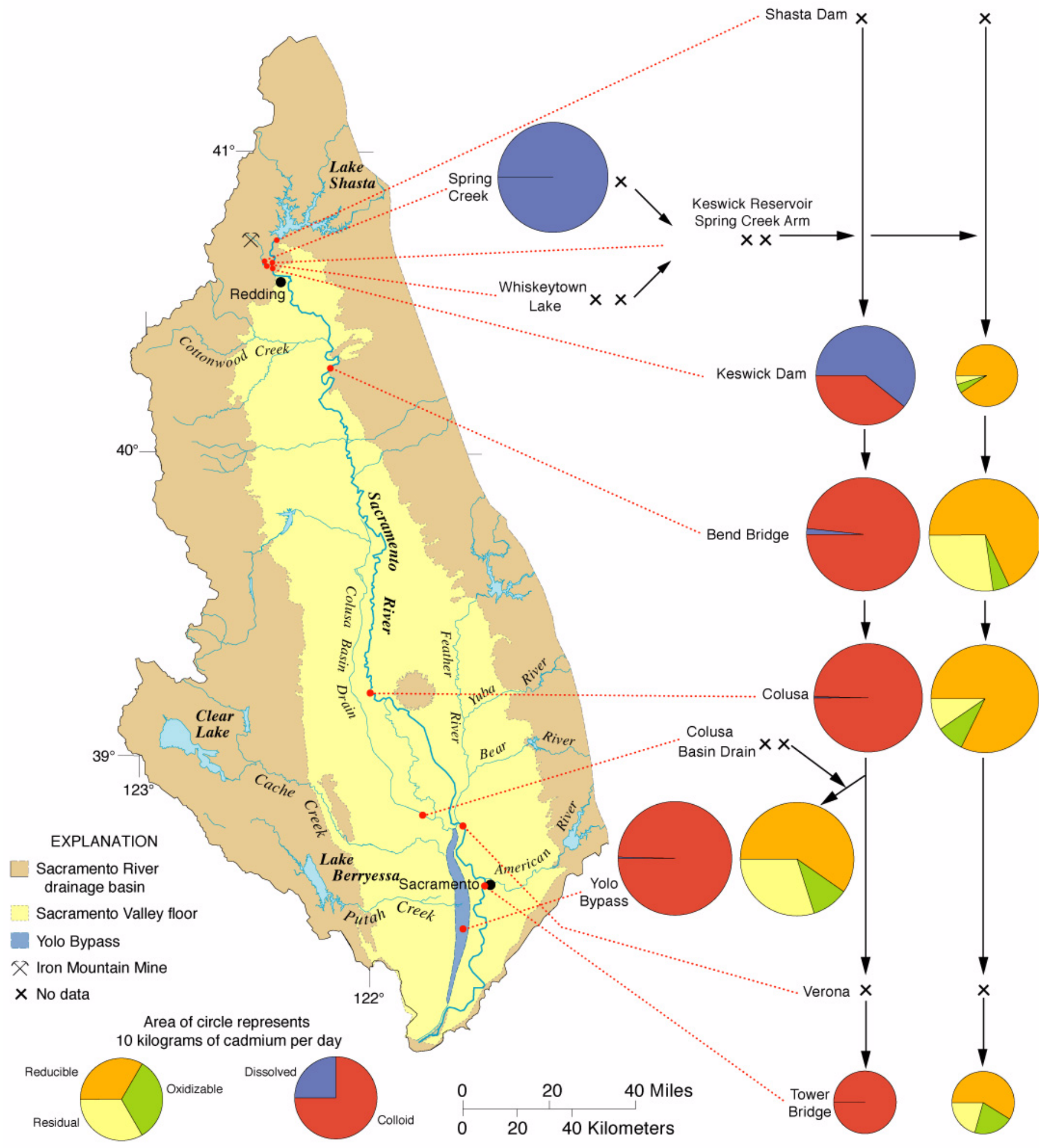

Figure 17A. Distribution and speciation of colloidal cadmium loads during January 1997, Sacramento River, California, and selected tributaries. 


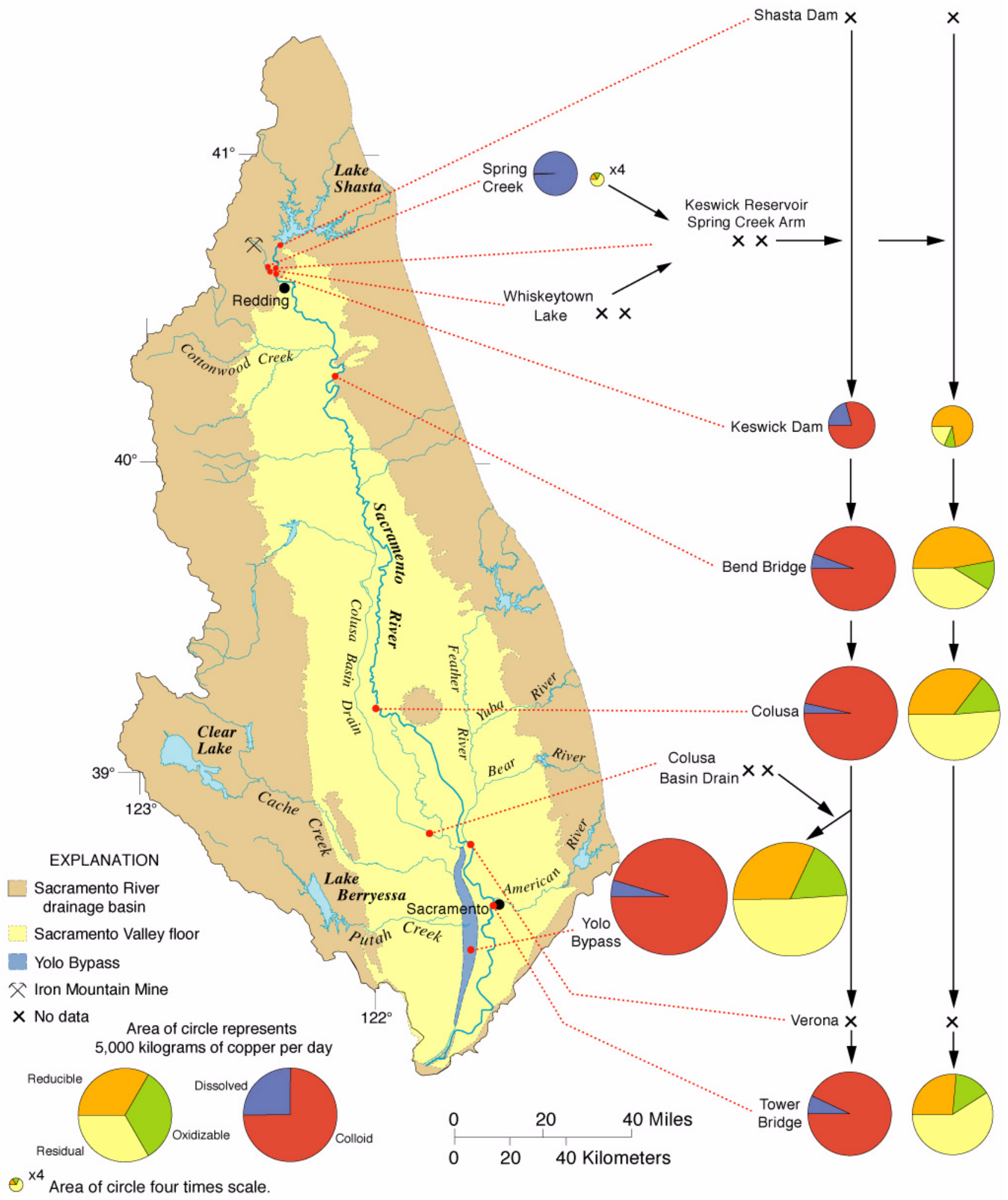

Figure 17B. Distribution and speciation of colloidal copper loads during January 1997, Sacramento River, California, and selected tributaries. 


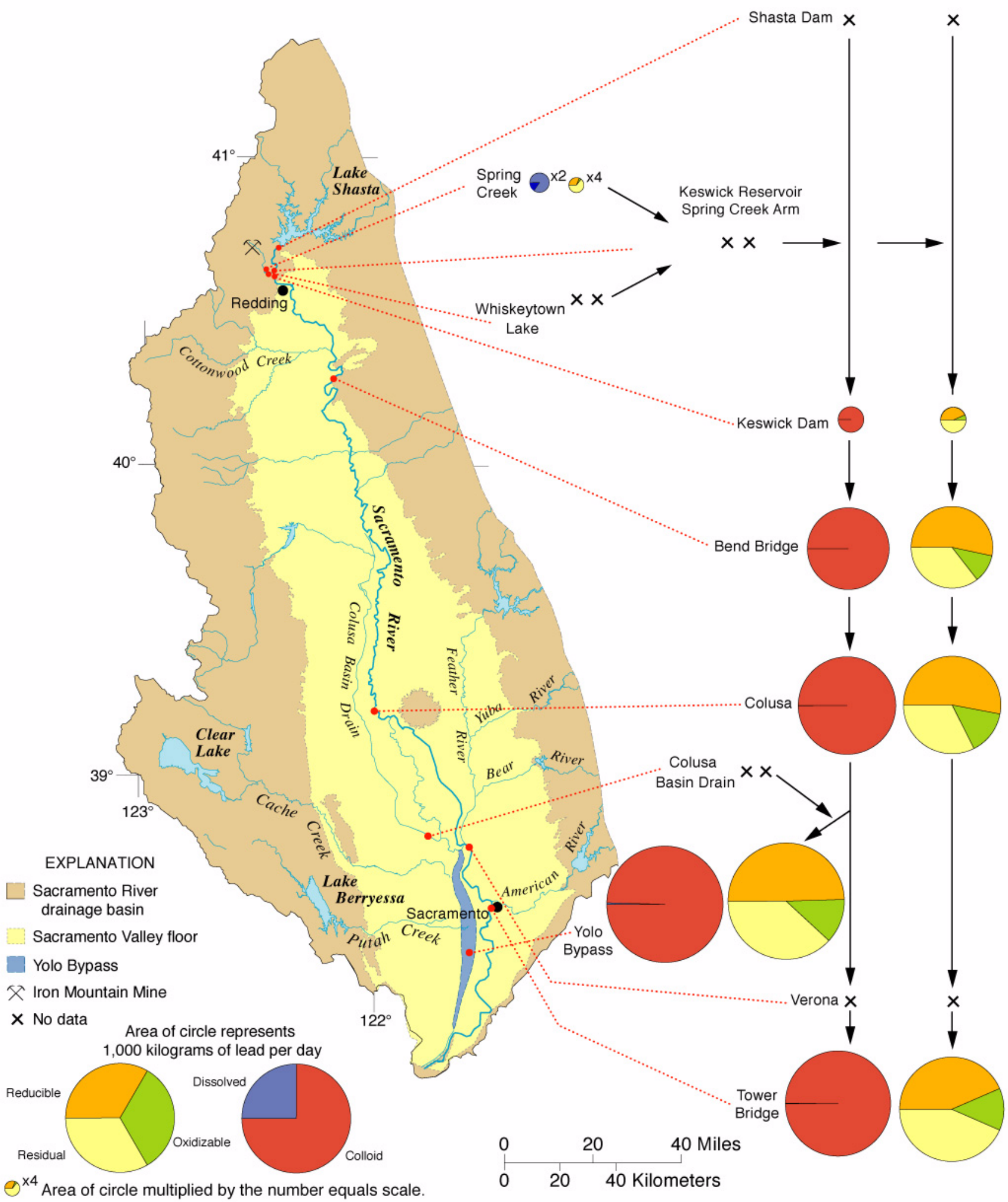

Figure 17C. Distribution and speciation of colloidal lead loads during January 1997, Sacramento River, California, and selected tributaries. 


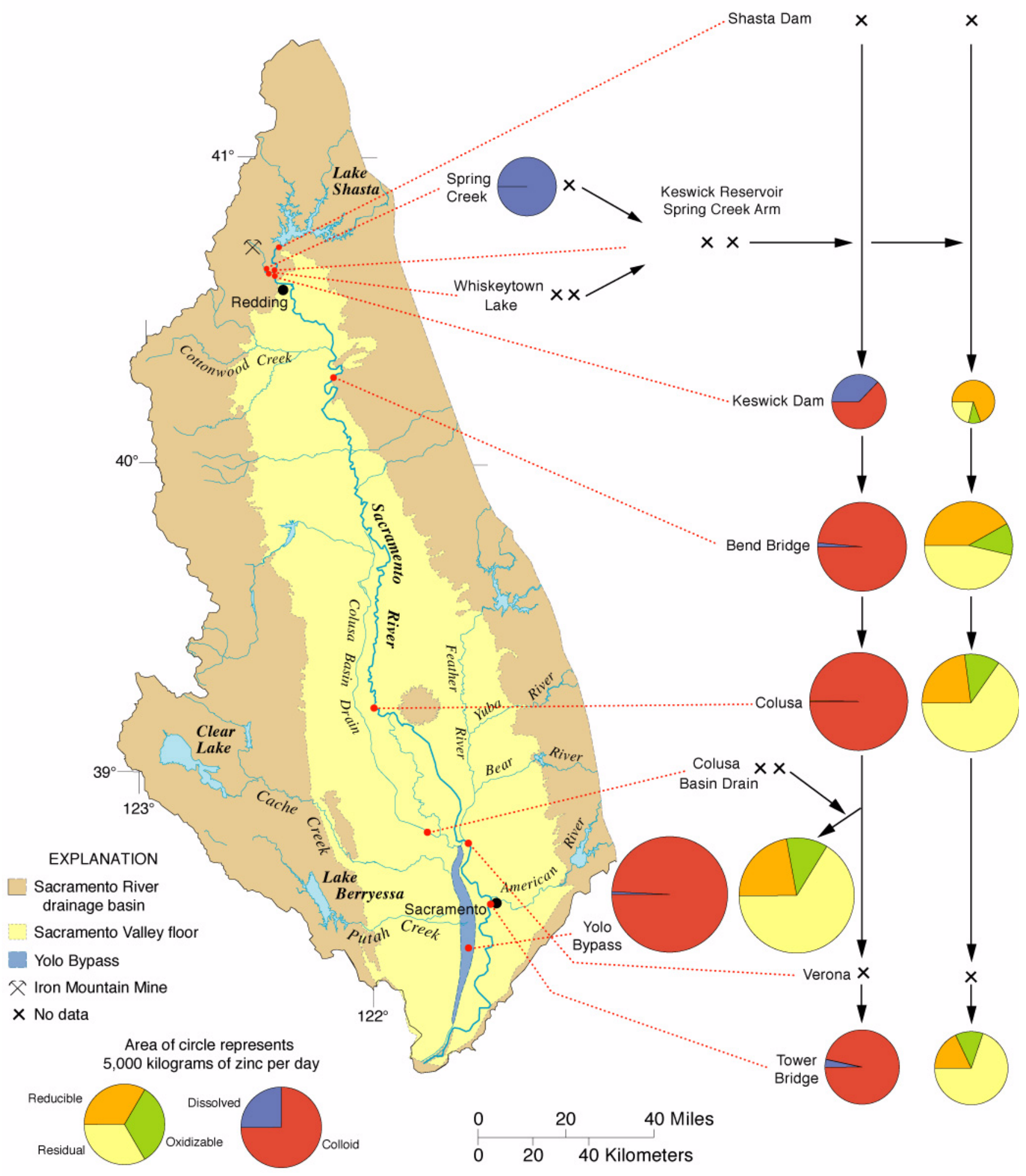

Figure 17D. Distribution and speciation of colloidal zinc loads during January 1997, Sacramento River, California, and selected tributaries. 


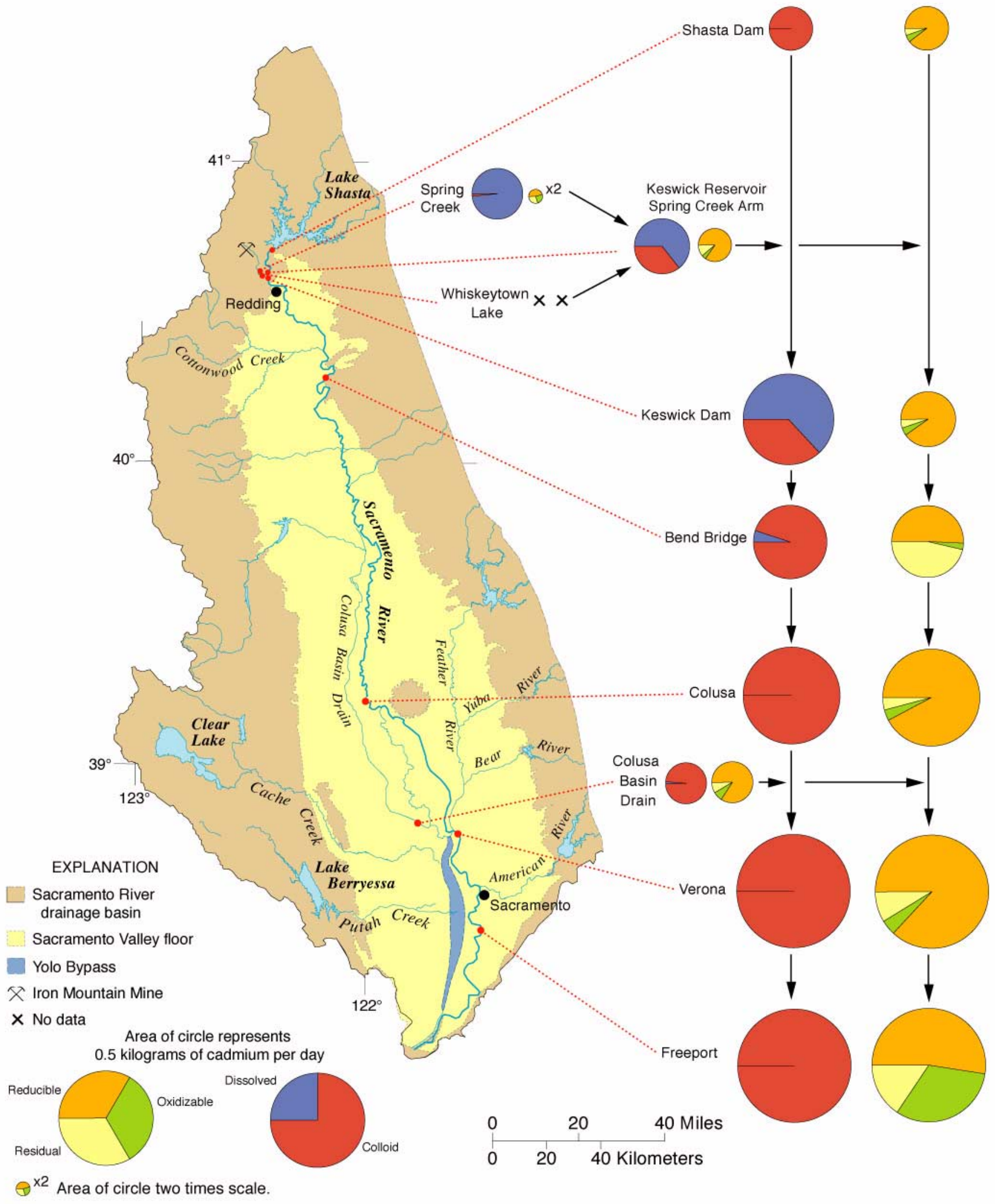

Figure 18A. Distribution and speciation of colloidal cadmium loads during May-June 1997, Sacramento River, California, and selected tributaries. 


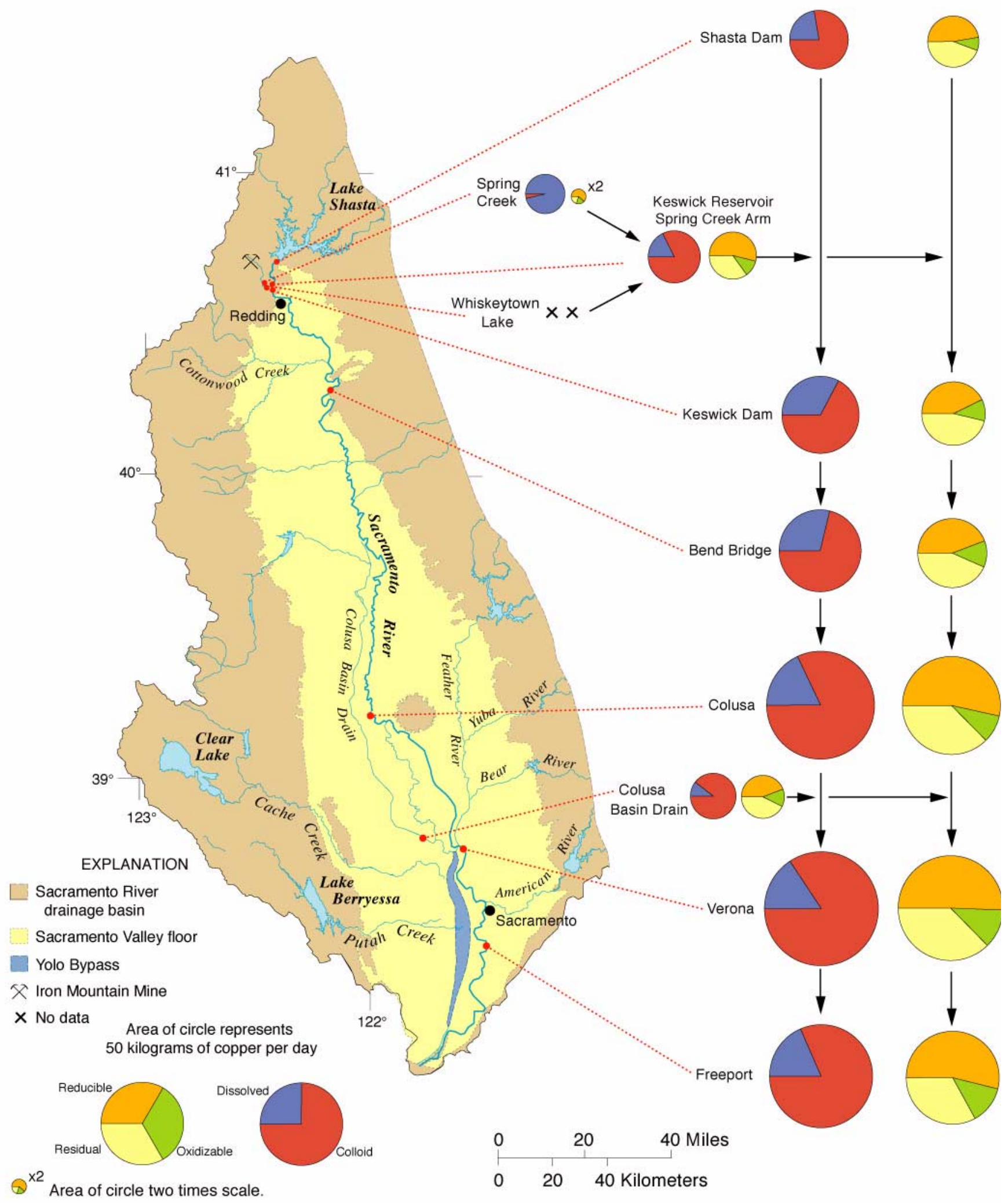

Figure 18B. Distribution and speciation of colloidal copper loads during May-June 1997, Sacramento River, California, and selected tributaries. 


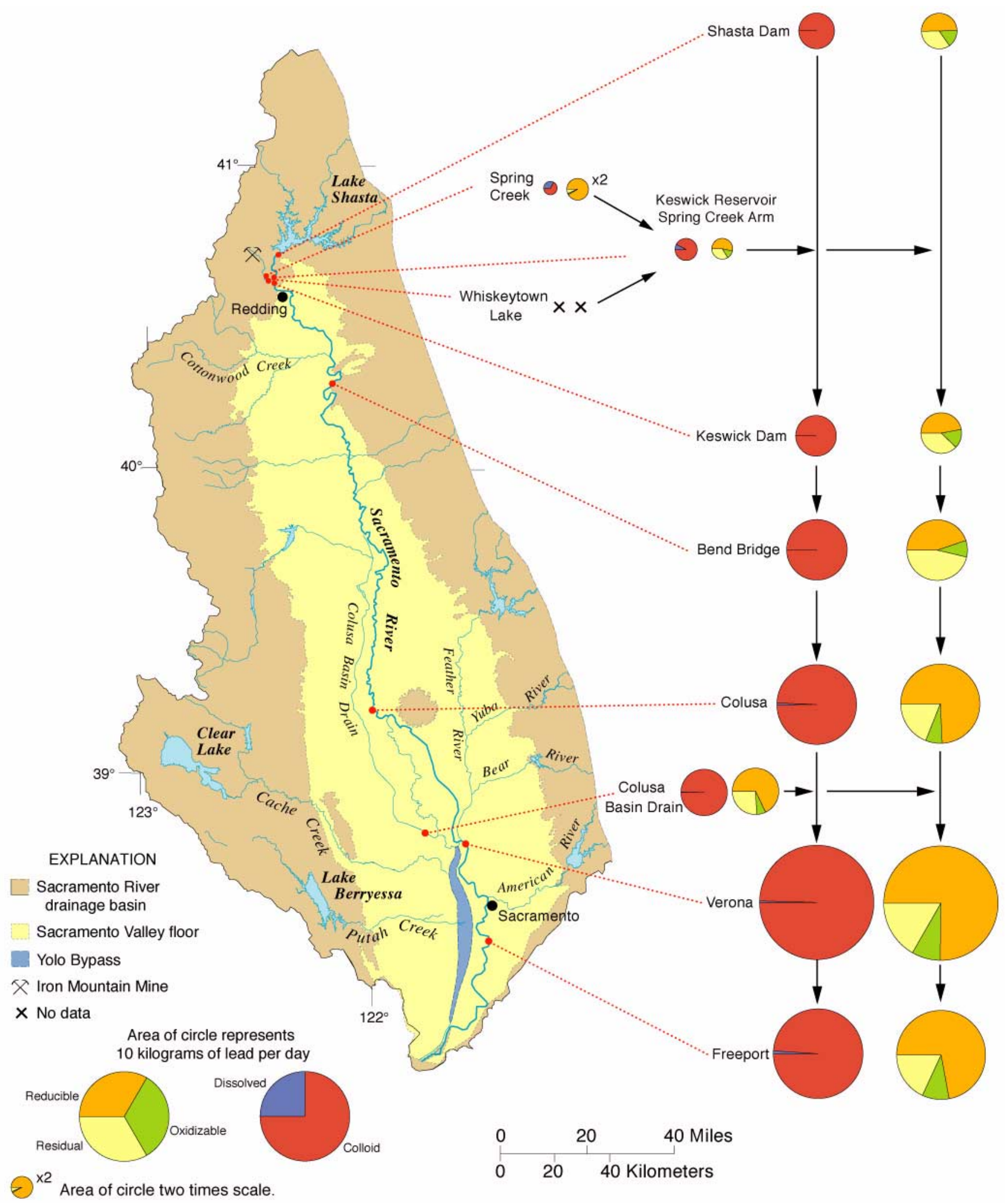

Figure 18C. Distribution and speciation of colloidal lead loads during May-June 1997, Sacramento River, California, and selected tributaries. 


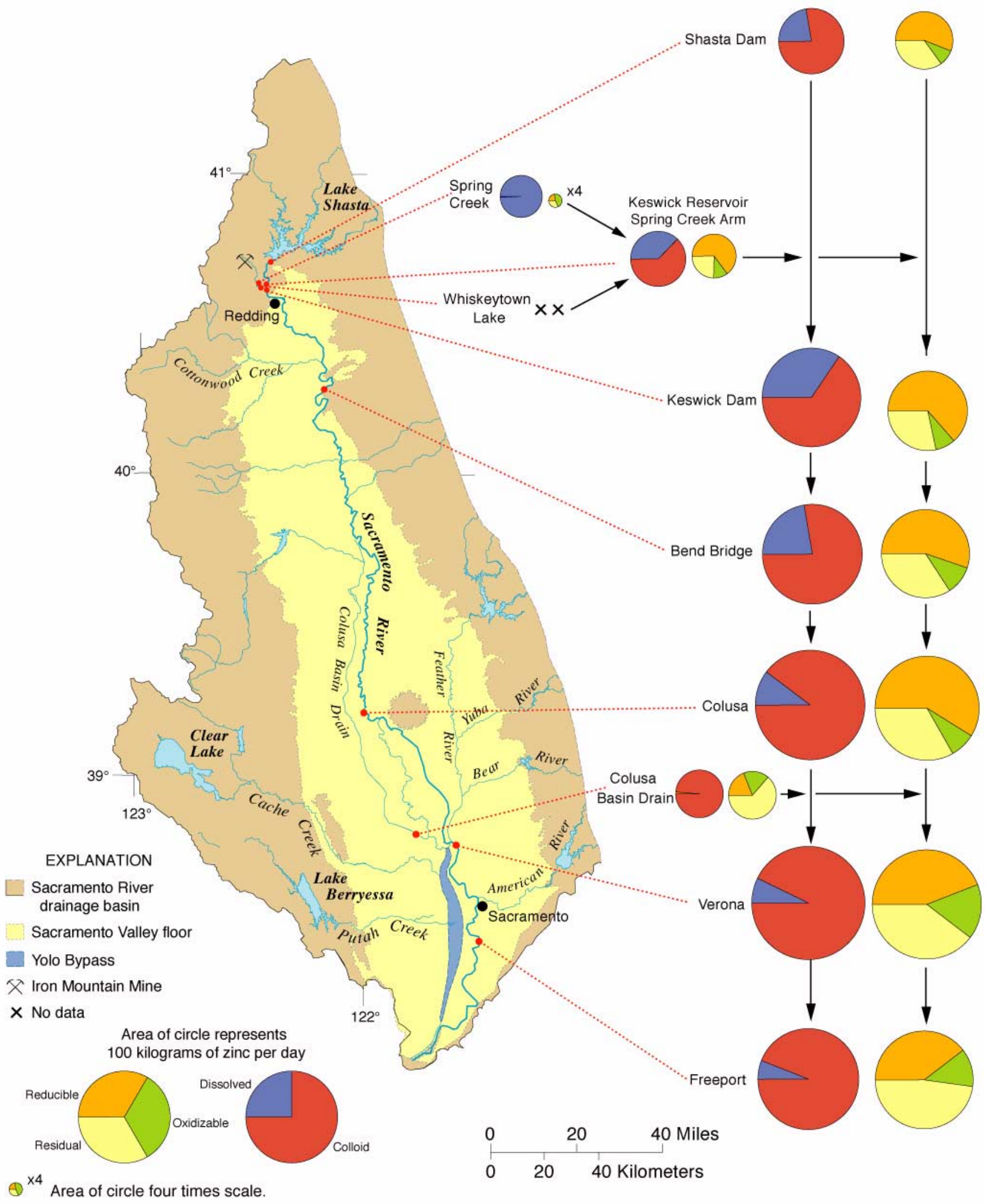

Figure 18D. Distribution and speciation of colloidal zinc loads during May-June 1997, Sacramento River, California, and selected tributaries. 
in colloids and are likely to play an important role in controlling trace metal distribution. Spatial and temporal variations in mercury loads for concurrent samples are described elsewhere (David Roth, U.S. Geological Survey, written commun., 1999), although dissolved and colloidal mercury loads for each sampling period are tabulated in Appendix 1 of this report (table A1-7). Pther trace metals of environmentar concern sucn as nickel are discussed briefly.

\section{Temporal Variations in Dissolved and Colloidal Loads}

The greatest metal loads carried by the Sacramento River during this study are associated with the January 1997 sampling period (figs. 4 through 9) because of a combination of highest discharge and highest colloid concentrations (figs. 10 through 15). Metal loads during the December 1990 sampling period were consistently the second largest of the six sampling periods. In general, January 1997 metal loads exceeded those of all of the other sampling periods, except December 1996, by a factor of 20 to 30, and exceeded December 1996 loads by a factor of 3 to 4 . For example, at Colusa during sampling in early January 1997, the Sacramento River was transporting $30 \mathrm{~kg}$ of cadmium per day, $8,400 \mathrm{~kg}$ of zinc per day, and 4,800 kg of copper per day. In midDecember 1996, the corresponding loads were $8.2 \mathrm{~kg}$ of cadmium per day, 2,500 $\mathrm{kg}$ of zinc per day and $1,200 \mathrm{~kg}$ of copper per day. As discussed in more detail in a later section, the other four sampling periods took place during lower-flow conditions, with correspondingly lower metal transport rates at Colusa: less than $3 \mathrm{~kg}$ of cadmium per day, less than $400 \mathrm{~kg}$ of zinc per day, and less than $300 \mathrm{~kg}$ of copper per day.

In contrast to the large differential between metal loads during January 1997 and other sampling periods, discharges during January 1997 at most sampling sites were only about twice the discharges in December 1996 and only up to about ten times the discharges for the other four, lower-flow sampling periods. Suspended colloidal concentrations (that is, the mass of colloids being carried in the river per unit volume) followed similar patterns to discharge. On average, suspended colloid concentrations were about 3 to 4 times higher in January 1997 than in December 1996 and 3 to 10 times the concentrations during any of the other four sampling periods.
About 70 percent of the total annual discharge of the Sacramento River system (measured at Freeport and the Yolo Bypass; fig. 1) during the water year July 1996 to June 1997 occurred from December 1, 1996 to February 28, 1997 (Alpers and others, 2000). Periodic measurements of suspended sediment concentration at Freeport showed a positive correlation with discharge (fig. 19). ncreased discharge and increased suspended secilment concentrations (including colloids) resulted in substantially larger metal loads during the high-flow periods. These observations indicate that for the water year during which the study was made (July 1, 1996 through June 30, 1997), most of metals in the Sacramento River were transported during a relatively short period of time, during highest flow conditions.

Among the four sampling periods during lowerflow conditions (July, September, and November 1996 and May-June 1997), the period with the highest loads varied among the sampling sites. In relation to the upstream sampling sites at Shasta Dam, Keswick Dam, and Bend Bridge, the loads of cadmium, copper, lead, and zinc during July 1996 generally were higher than the loads during the other lower-flow sampling periods. At the downstream sampling sites Verona and Freeport, the September 1996 loads for these metals generally were the highest among the four lower-flow sampling periods. At Colusa, the four lower-flow sampling periods showed similar loads for each of these trace metals, with the exception that lead and zinc loads were lowest among these four sampling periods during September 1996 (figs. 8 and 9), whereas copper loads were highest during scptember 1996 (fig. 6). Tron loads at Colusa also were at a

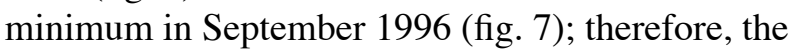
higher copper loads during this sampling period likely were not associated with iron-rich colloids.

Spring Creek was sampled during three of the sampling periods (December 1996, January 1997, and May-June 1997), during which the temporal variability of metals loads was similar to that observed at the mainstem Sacramento River sites. For Spring Creek, January 1997 loads were much greater than those of December 1996, which in turn surpassed those of May-Iune 1997 for $\mathrm{Al}, \mathrm{Cd}, \mathrm{Cu}, \mathrm{Fe}, \mathrm{Pb}$, and $\mathrm{Zr}$ (Appendix 1). The major contrast between Spring Creek and the mainstem river sites was the magnitude of the temporal variability. Spring Creek loads in January 1997 tended to exceed loads in December 1996 by factors of 5 to 12 , and by factors of more than 

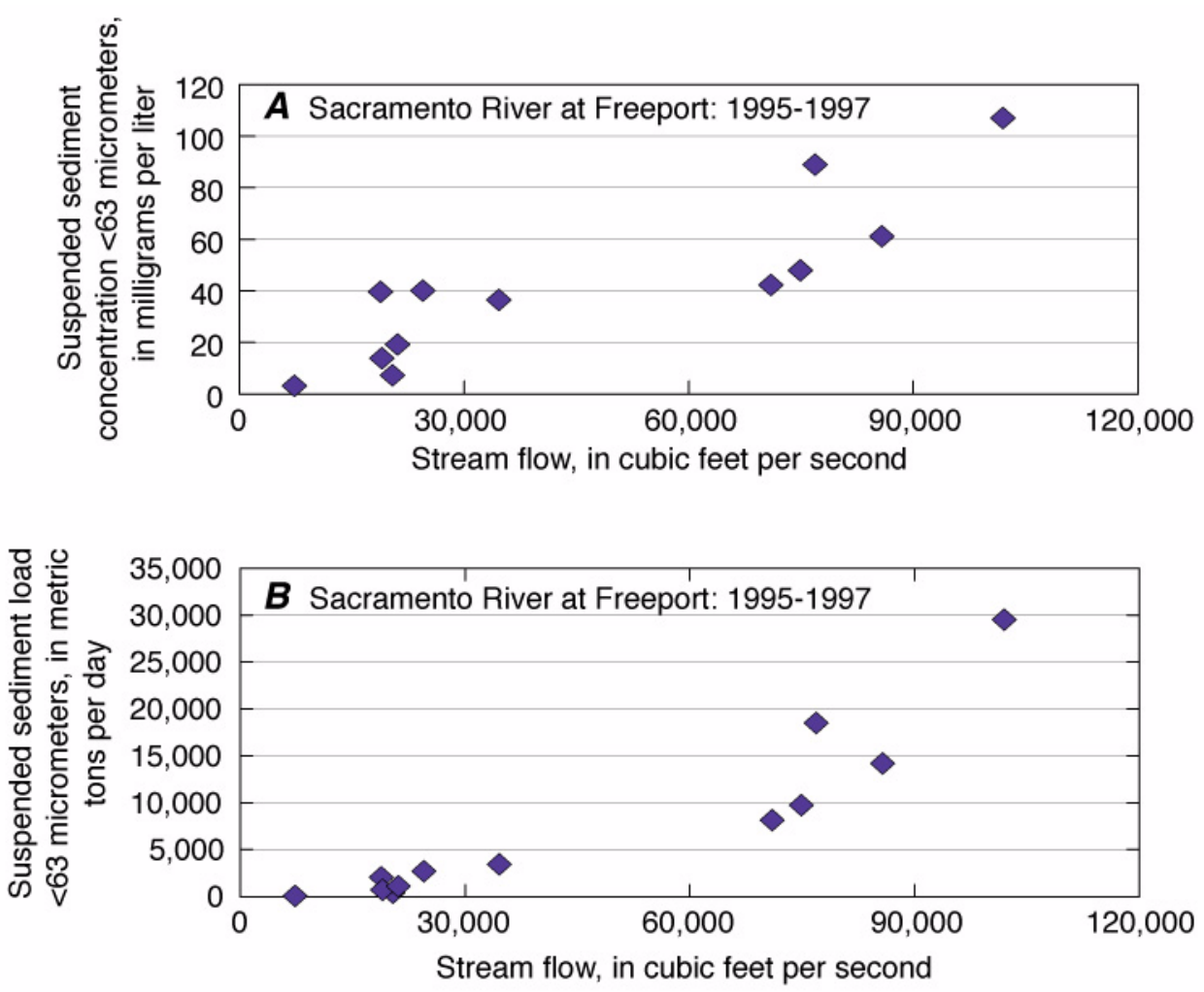

Figure 19. Plots of suspended sediment concentration $(A)$ and load $(B)$ versus stream flow at Freeport, California, July 1995 through June 1997.

100 compared with loads in May-June 1997. These differences were caused by high flows from Spring Creek Reservoir during the January 1997 floods. A contributing factor to this effect was the fact that a diversion of Upper Spring Creek above the Boulder Creek confluence into Flat Creel (fig. 2) yas not operative during early January 1997 , because the floods had washed out a bridge on Iron Mountain Road. Therefore, the flows to Spring Creek Reservoir were increased by several hundred cubic feet per second, contributing to a spill condition. On January 2, 1997 the daily average flow from the Spring Creek Debris Dam (SCDD) was $750 \mathrm{ft}^{3} / \mathrm{s}$, including releases from the gates within the dam plus the flow over the spillway.

Water from Whiskeytown Lake, which is diverted into the Spring Creek arm of Keswick Reservoir through the Spring Creek Power Plant (SCPP, fig. 2), was sampled on two occasions for this study (December 1996 and May-June 1997).

Although no samples for colloidal material were collected, total recoverable analyses of whole-water samples collected at these times can serve as proxies for colloidal plus dissolved analyses. The trends seen throughout the rest of the watershed concerning the dominance in loads during December 1996 over May-June 1997 are not observed in the water samples from Whiskeytown Lake; May-June 1997 loads for aluminum and iron were considerably higher than December 1996 loads (Appendix 1), despite the fact that discharge on the sampilimg tate of May 29, 1997 was $2,720 \mathrm{ft}^{3} / \mathrm{s}$ versus $3,900 \mathrm{ft}^{3} / \mathrm{s}$ on December 11 , 1996 (Alpers and others, 2000). Trace metal loads from Whiskeytown Reservoir generally were much lower than the metal loads from Spring Creek, as discussed in a later section of this report (Mass Balance and Metal Transport in Keswick Reservoir).

Temporal variations in the relative proportion of dissolved and colloidal loads were markedly different for Spring Creek compared with the mainstem Sacramento River sites. During two of the three sampling periods at Spring Creek (December 1996 and January 1997), the dissolved load was greater than 50 percent of the total for lead, aluminum, and iron; during the May-June 1997 trip, the loads in Spring Creek were less than 50 percent dissolved for these metals. For cadmium, copper, and zinc, the proportion of the load in Spring Creek that was dissolved was greater than 95 percent for all three sampling periods. In contrast, at the Shasta Dam and Keswick Dam 
sampling sites, the proportions of the metal load from dissolved copper were approximately $50(+25)$ percent for all six sampling periods (fig. 12), a though the site below Shasta Dam was not sampied in January 1997.

During the January 1997 sampling period, almost all of the $\mathrm{Al}, \mathrm{Cd}, \mathrm{Cu}, \mathrm{Fe}, \mathrm{Pb}, \mathrm{Hg}$, and $\mathrm{Zn}$ loads were associated with colloids at all of the downstream mainstem Sacramento River sites (from Bend Bridge to Freeport) (figs. 4-15; David Roth, U.S. Geological Survey, written commun., 1999). These results were due to the much higher total colloidal concentrations combined with the higher discharge during this extremely high-flow period. The only site for which more than 10 percent of the cadmium, copper, and zinc loads was dissolved during the January 1997 sampling period was the site below Keswick Dam (the site below Shasta Dam was not sampled during January 1997). In contrast, cadmium, copper, and zinc had considerably higher proportions of dissolved loads during other sampling periods (including December 1996) at the downstream sites (figs. 5, 6, an 19) This was not observed for lead, iron, and aluminum, for which the dissolved proportion of the load was relatively small regardless of the time of year (figs. 4 , $7, \operatorname{and} 8$ ).

\section{Cadmium, Copper, and Zinc}

As noted earlier, the highest cadmium loads observed in this study were during the January 1997 sampling period, followed by the December 1996 period (fig. 5). Cadmium loads at the upstream sites, including Shasta Dam and Keswick Dam and, to a lesser extent, Bend Bridge, had a large dissolved component; for all six sampling periods, more than 50 percent of the cadmium load below Keswick Dam was in dissolved form (figs. 5 ar 111). Downstream mainstem sampling situs invariauty showed a decline in the proportion of dissolved cadmium.

With regard to cadmium loads, there is a clear impact on the Sacramento River system from Spring Creek during certain flow regimes (figs. 5 and 11). Spring Creek carries the acid drainage from the mines at Iron Mountain and enters Keswick Reservoir about 2 mi upstream of Keswick Darn (fig. 2). Pepending on the flow regime, a significant proportion of the cadmium load may come from Shasta Lake and its tributaries. During the July, September, and December 1996 sampling periods, the cadmium load below
Shasta Dam was more than 50 percent of the cadmium load below Keswick Dam. (There are no data from this study regarding colloidal cadmium transport from Shasta Lake for either the September 1996 or January 1997 sampling periods.) Finally, except for one sampling point during one sampling period (below Keswick Dam, May-June 1997), total cadmium loads uniformly increased between the Shasta Dam site and the Colusa site; during the July 1996, September 1996, and January 1997 sampling periods, cadmium loads continued to increase downriver to Freeport. In summary, there appear to be inputs of cadmium to the Sacramento River system both above Shasta Dam and above Keswick Dam that are primarily related to mine drainage; these were apparently the dominant inputs during the sampling periods in November and December 1996 and May-June 1997. During the sampling period of January 1997, the flood conditions caused transport of abundant colloidal material below Keswick Dam that dominated cadmium transport.

The decreases in cadmium transport observed along the flow path between the Colusa and Freeport sites during the November 1996, December 1996, and May-June 1997 sampling periods are likely related to large decreases in overall colloidal concentration (fig. 11). Figures 16 through 18 derhonstrate that greater than 50 percent of the colloidal cadmium occurs in a reducible phase such as hydrous iron and manganese oxides, and that this proportion does not change in a systematic way either spatially or temporally.

Generally, the patterns described above for cadmium are similar to those for zinc (figs. 9 and 15). The greatest zinc loads occurred durify the December 1996 and January 1997 sampling periods; upriver sites (especially Keswick Dam) showed zinc transport to have a large dissolved component, usually greater than 50 percent (fig. 15). Zinc loads at Shasta Dam were greater than 50 percent of the loads at Keswick Dam for July 1996 and December 1996 (no data for Shasta Dam in September 1996 or January 1997). Total zinc loads tended to increase uniformly between Shasta Dam and Colusa. As with cadmium, zinc transport increased continually between Keswick Dam and Freeport during the September 1996 and January 1997 sampling periods. Decreases in loads of zinc (and most other metals) between Colusa and Freeport for some sampling periods are apparently related to the anomalously high colloidal concentrations observed consistently at Colusa (figs. 10-15). 
Processes responsible for the consistent increase in the concentrations of colloids at Colusa relative to sampling sites immediately upstream and downstream remain unknown. There are no anthropogenic causes of fine-grained sediment, such as construction activity, that are known to have been active during the study period, nor is there much activity from industrial sites, agricultural drainage, or municipal sewage treatment plants in the vicinity. Also, there are no major tributary streams in the reach of the Sacramento River immediately upstream of Colusa. A longitudinal profile of riverbed elevation in the Sacramento River (fig. 20) indicates that the gradient near Colusa is significantly lower than at Bend Bridge, the closest upstream sampling station. This change in slope could have led, over many years, to deposition of fine-grained sediments on the streambed in the area upstream of Colusa. Levees for flood control regulate the river in the immediate vicinity of Colusa. A linear, engineered streambed would have higher water velocities, leading to increased sheer stresses that would cause the resuspension of fine-grained sediments from the river channel.

Some differences between zinc and cadmium speciation in colloids are evident in the data for samples collected during December 1996 and January 1997 (f gs. 16A, 16D, 17A, and 17D). Colloidal zinc during high flow tended to have a much higher proportion in the residual phase than in the reducible phase, especially at downriver sites. Inspection of the zinc/ cadmium ratios for dissolved and colloidal analyses in which both elements were detected (fig. 21A) reveals that dissolved zinc/cadmium ratios are consistently lower than colloidal zinc/cadmium ratios for sites both upstream and downstream of Redding. The zinc/ cadmium ratios in dissolved samples range from 40 to 210. Box illustrations defining the probability distribution of 25 to 75 percent of the data for dissolved samples (fig. 21A) range from about 50 to 100 for sites downstream of Redding and from about 100 to 410 for sites upstream of Redding, with most (19 of 27 samples) in the range of 70 to 150 . In contrast, the zinc/cadmium ratios in colloidal samples had an overall range from about 100 to 410 . The probability distribution for 25 to 75 percent of the data fall within the range of 150 to 260 for downstream sites and about 190 to 320 for upstream sites. Thus, there is a clear and consistent pattern of higher zinc/cadmium ratios in colloids relative to the dissolved component. The pattern holds true at individual sample sites as well. These differences are consistent with laboratory data that indicate that zinc will adsorb to sediment preferentially to cadmium at a given $\mathrm{pH}$ (Dzombak and

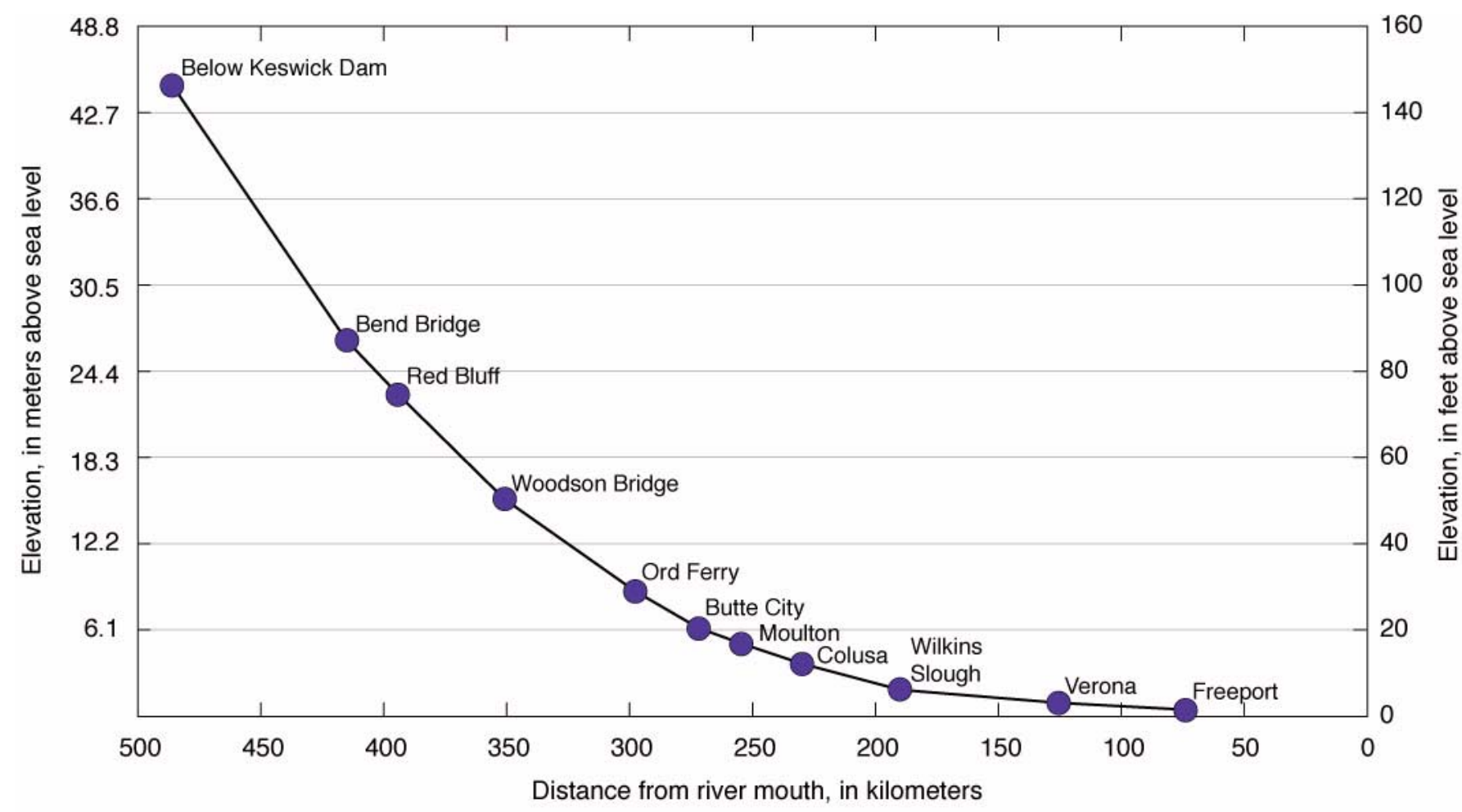

Figure 20. Graph showing elevation of streambed in relation to distance from river mouth, Keswick Dam to Freeport, Sacramento River, California. 
Morel, 1990; Smith, 1999). Although there are some apparent trends of zinc/cadmium ratios in colloids and dissolved components with distance, there are not a sufficient number of dissolved cadmium determinations above the detection limit to warrant quantitative analysis.

The zinc/cadmium ratios observed in colloids from the Sacramento River are consistent with massive sulfide deposits as a source (Hamlin and Alpers, 1996). Seal and others (in press) have compiled data for mine drainage and natural acid rock drainage from six different types of massive sulfide deposits, showing that the zinc/cadmium ratio does not change appreciably among these types of deposits in various geologic settings. Also, the zinc/cadmium ratio in average crustal rocks is in a similar range (approximately 50 to 200; Clark, 1924), therefore, this ratio is not a definitive tracer for mining-related metal sources.

Temporal and spatial trends in copper loads show some similarities to those for zinc and cadmium loads. For example, the December 1996 and January 1997 sampling periods during high flow account for the highest copper loads described at all sites on the river. Also, the proportion of dissolved copper was always greatest at upriver sites, however the proportions did not decrease with distance downriver in the same ways as they did for cadmium and zincloads (compare the pie graphs in fig. $12 \mathrm{w}$ ith those in figs. 11 and 15). Finally, as with zinc, the reducible fraction of copper generally accounted for about 50 percent of the total colloidal copper (fig. 16B. $17 B$, and 18B), but this proportion decreased as copper in the residual phase increased downstream during the January 1997 sampling period (fig. 17B).

Variations in zinc/copper ratios for dissolved and colloidal components show contrasting patterns at sites upstream and downstream of Redding (fig. 21B). At the upstream sites, zinc/copper ratios in tile dissolved component are consistently higher than those in the colloidal phase. The 25 to 75 percent probability range for dissolved zinc/copper in upstream sites is from about 2.3 to 4.2 , whereas the corresponding box range for colloidal zinc/copper in upstream sites is from about 1.1 to 2.2 (fig. $21 B$ ). This relation is consistent with preferential adsorption of copper relative to zinc onto suspended matter at a given pH (Dzomback and Morel, 1990; Smith, 1999). However, at the sampling sites downstream of Redding, the relation of the zinc/copper ratio between dissolved and colloidal components is reversed from that observed upstream. The 25 to 75 percent probability range for zinc/copper in the dissolved

component for downstream sites is about 0.5 to 1.3 , whereas the corresponding range for zinc/copper in the colloidal component is 1.5 to 2.1 . The contrasting behavior of the zinc/copper ratio at the downstream sites may be caused by aqueous complexation of copper by dissolved organic carbon, a process that does not affect zinc to the same degree (Stumm and Morgan, 1996). Concentrations of dissolved organic carbon tend to increase with distance downstream in the Sacramento River (Alpers and others, 2000), which may play a role in the partitioning of copper and zinc between the dissolved and colloidal components.

The adsorption and desorption behavior of zinc and copper were investigated in laboratory studies using sediment samples from the Spring Creek arm of Keswick Reservoir (Coston and others, 1998; Nordstrom and others, 1999). The presence of schwertmannite, a sulfate-bearing ferric oxyhydroxide, likely causes a shift to adsorption at lower $\mathrm{pH}$ for a given amount of available surface area, relative to synthetic sulfate-free hydrous ferric oxides such as ferrihydrite (Coston and others, 1998; Webster and others, 1998). In the Sacramento River and Keswick Reservoir systems, the partitioning of cadmium, copper, and zinc between dissolved and colloidal phases appears to show some consistent relations between ambient field data and laboratory studies. The investigation of these relations is the focus of ongoing research by the USGS.

The ranges of zinc/copper ratios for the dissolved and colloidal components from the Sacramento River are consistent with an important source of these metals being primarily from the mineralized areas of the West Shasta mining district. The compilation by Seal and others (in press) indicates that drainage from different types of massive sulfide deposits exhibits a wide range of zinc/copper ratios. The deposits in the East Shasta and West Shasta mining districts are considered to be of the Noranda-type (Franklin and others, 1998), which typically have zinc/copper ratios between 1 and about 20 (Seal and others, in press).

\section{Lead, Aluminum, and Iron}

The transport behavior of lead is distinct from that of cadmium, copper, and zinc. The proportion of dissolved lead load is uniformly negligible, except for occasional observations at the sampling sites below 

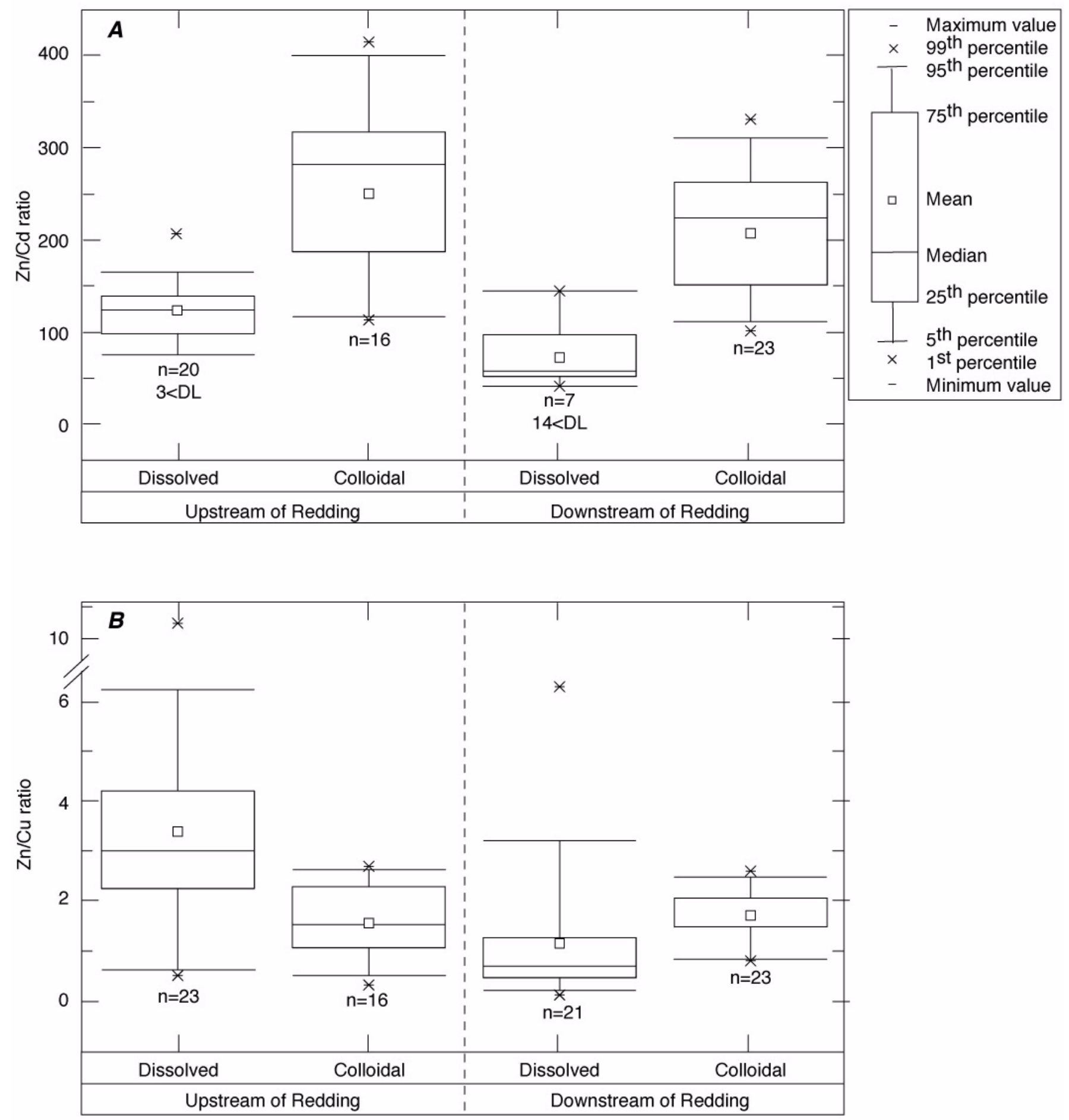

Figure 21. Probability box illustrations showing distribution of $(A) \mathrm{Zn} / \mathrm{Cd}$ and $(B) \mathrm{Zn} / \mathrm{Cu}$ data in dissolved and colloidal samples taken July 1996 through June 1997, Sacramento River, California. <DL, less than detection limit; n, number of observations greater than the detection limit. Cd, cadmium; Cu, copper; $\mathrm{Zn}$, zinc. 
Keswick Dam and Shasta Dam. Almost all of the lead carried in the river is associated with suspended (colloidal) sediments (figs. 8 an 14). Also, in comparison with cadmium, copper, and zinc, the ratio of the transport below Keswick Dam to that at Freeport (plus the Yolo Bypass) is much smaller (compare the upriver pie chats for kat with those for cadmium. copper. or zinc it figures 16-18, and see Appendix 1 table A1-5 and Appendix 2, table A2-5.). This smaller ratio indicates that there are probably other, more significant sources of lead in the Sacramento River watershed besides the mined areas upstream of Keswick Dam. Lead isotope data (Alpers and others, 2000) also are consistent with this interpretation.

The proportion of lead in the reducible phase of the colloids was almost always greater than or equal to about 50 percent, as was the case for copper and zinc (figs. 16-18). The reducible lead fraction in colloids was occasionally as high as 75 percent; for example at the Colusa and Verona sites during May-June 1997. The only time at which lead associated with the reducible phase was less than 50 percent of the total colloidal lead was during the January 1997 sampling period (at the mainstem sites below Keswick Dam and at Tower Bridge).

The quantities of transported aluminum and iron were similar in magnitude to each other, and the spatial and temporal variations of these two metals had similar characteristics. As with lead, practically all the aluminum transported in the Sacramento River was colloidal, except below Shasta and Keswjck dams during certain sampling periods (fig. 10); a similar pattern was obtained for iron (fig. 13) A major difference between lead and aluminum speciation is that practically all of the colloidal aluminum is associated with the residual phase, whereas colloidal lead tends to be associated with the reducible phase, suggesting a close affinity for hydrous iron oxides.

Iron tended to behave similarly to aluminum at most sampling sites, with the majority of the colloidal iron (80 to 90 percent) in the residual phase. As expected, the colloid samples collected at Spring Creek, in the Spring Creek arm of Keswick Reservoir, and below Keswick Dam were exceptions to this behavior in that they had a substantial proportion of iron in the reducible phase. The iron speciation and loading data appear to indicate that Iron Mountain mine and Spring Creek are not the predominant sources of iron to the Sacramento River. The transformation of dissolved iron in Spring Creek into particulate forms of ferric iron occurs by two related mechanisms, the oxidation of ferrous iron to ferric iron and the subsequent hydrolysis of the ferric iron (Nordstrom and Alpers, 1999a). Ferrous iron actively oxidizes in the Spring Creek Reservoir, contributing abundant hydrous ferric oxide colloids to Spring Creek. The acidic water of Spring Creek carries some soluble ferric iron, which precipitates by hydrolysis caused by neutralization on mixing with dilute waters in Keswick Reservoir from both Whiskeytown Lake and Shasta Lake.

\section{Discussion of Transport and Fate of Metals from Various Sources}

The purpose of this section is to discuss the spatial variation of metal loads in the context of known and suspected metal sources. The discussion is divided into both known sources from abandoned and inactive mines in the Shasta region, mostly upstream of Keswick Dam (Nordstrom and others, 1977), and less known sources downstream of Keswick Dam. The section on Keswick Reservoir includes some analysis of metal mass balance in the Spring Creek arm of the reservoir and in the reservoir as a whole.

\section{Copper-Zinc-Lead Mines in the Shasta Region}

Volcanogenic massive sulfide deposits of the East Shasta and West Shasta mining districts are important sources of trace metals to the Sacramento River system and its tributaries. This section describes these sources and discusses available data from other studies on associated metal loads, for comparison with data generated in this study.

\section{Mines Draining into Shasta Lake and Its Tributaries}

The East Shasta mining district includes the abandoned Bully Hill and Rising Star mines, which drain into Town Creek and Horse Creek, respectively. Mineralization in the East Shasta mining district is hosted by Permian and Triassic strata, with an age of approximately 200 to 300 million years (Albers and Bain, 1985). Town Creek and Horse Creek are relatively small tributaries to Shasta Lake in its northeast corner. Copper loads were estimated to be $1.8 \mathrm{~kg} / \mathrm{d}$ from the Bully Hill mine and $2.3 \mathrm{~kg} / \mathrm{d}$ from the Rising Star on an annualized average basis, from periodic monitoring (Dennis Heiman, Regional Water 
Quality Control Board, Central Valley Region, written commun., 1998).

Acidic drainage from several of the copper-zinc mines of the West Shasta mining district flows into Shasta Lake by way of two tributaries: Little Backbone Creek and West Squaw Creel (fig. 2). Mineralization in the West Shasta mining district is Devonian age (about 400 million years old), and consists of massive sulfides hosted by hydrothermally altered rhyolite and greenstone with minimal neutralizing capacity. The Mammoth, Golinsky, and Sutro mines in the Little Backbone Creek watershed are estimated to contribute copper loads of 32, 0.5, and $0.05 \mathrm{~kg} / \mathrm{d}$, respectively, on an annual basis, as indicated by periodic monitoring (Dennis Heiman, Regional Water Quality Control Board, Central Valley Region, written commun., 1998). In the West Squaw Creek drainage, the contribution of copper loads from the Balaklala, Keystone, Shasta King, and Early Bird mines are estimated to be $9,1.1,0.5$, and $0.05 \mathrm{~kg} / \mathrm{d}$, respectively (Dennis Heiman, Regional Water Quality Control Board, Central Valley Region, written commun., 1998).

The total copper loads to Shasta Lake from the mines mentioned above is estimated to be about $50 \mathrm{~kg} / \mathrm{d}$, averaged throughout the year (Dennis Heiman, Regional Water Quality Control Board, Central Valley Region, written commun., 1998). The Regional Water Board advises that “*** these are estimated loading rates based on periodic monitoring and $* * *$ the actual discharge rate varies seasonally within any one year and between years based on annual precipitation" (Dennis Heiman, Regional Water Quality Control Board, Central Valley Region, written commun., 1998).

At the sampling site below Shasta Dam, the transport rate of total copper that is based on the sum of dissolved and colloidal loads (Appendix 1, table A1-3) ranged from 7 to greater than or equal to $180 \mathrm{~kg} / \mathrm{d}$. The comparable copper loads that are based on total recoverable analyses of unfiltered waters samples were approximately twice as high, ranging from 14 to $320 \mathrm{~kg} / \mathrm{d}$ (Appendix 1, table A1-3). However, no sample was collected from the site below Shasta Dam for the present study during the period of highest flow in January 1997. Sampling by the Regional Water Board during January 1997 indicates a total recoverable copper concentration of $8.2 \mu \mathrm{g} / \mathrm{L}$. (Total recoverable concentrations are based on a partial digestion of unfiltered water samples using nitric and hydrochloric acids at $\mathrm{pH}<2$.) Combining this value with an average discharge for January 1997 of $41,600 \mathrm{ft}^{3} / \mathrm{s}$ results in an estimated average total recoverable copper load of $830 \mathrm{~kg} / \mathrm{d}$ during this month of high discharge.

The data from this study, from the previous study by Nordstrom and others (1977), and from the monitoring data of the Regional Water Board indicate that abandoned mines are the source of a significant proportion of the copper loads to Shasta Lake. By analogy with data gathered for this study at Spring Creek, it is expected that copper, cadmium, zinc, and other trace metals are transported predominantly in dissolved form in acidic waters, for example, with $\mathrm{pH}$ values less than 5 , such as the drainage from the other inactive and abandoned mines in the Shasta region. The relatively high proportions of dissolved cadmium, copper, and zinc in water samples taken during this study below Shasta Dam are consistent with the interpretation that the abandoned mines are a significant source of these metals.

\section{Mines Draining into Keswick Reservoir and Its Tributaries}

The copper-zinc massive sulfide deposits at Iron Mountain (fig. 2) are the largest in the East Shasta and West Shasta mining districts. The overall premining size of the massive sulfide deposits at Iron Mountain is estimated at 23 million metric tons, occurring in five segments of an originally continuous lens that was displaced by normal faulting (Albers, 1985). Between the 1880s and the 1960s, about half of this tonnage was mined by underground and surface methods. Several adits remain open within Iron Mountain, serving as drains that have kept most of the unmined massive sulfide deposits in the unsaturated zone. Ready access of atmospheric oxygen and infiltrating meteoric water has resulted in optimal conditions for generation of acid mine drainage (Nordstrom and Alpers, 1995), producing some of the highest metal concentrations ever recorded in mine effluent (Nordstrom and others 1991; U.S. Environmental Protection Agency, 1992; Nordstrom and Alpers, 1995; 1999a,b; Nordstrom and others, 2000).

Prior to 1989, treatment of the metal-rich, acid drainage from Iron Mountain consisted solely of copper cementation plants operated intermittently on Boulder and Slickrock creeks. These plants, which were of variable effectiveness, used scrap iron to precipitate copper (U.S. Environmental Protection 
Agency, 1992). Average metal loads in Spring Creek, downstream of the Spring Creek Debris Dam (SCDD) for the nine-year period between 1977 and 1985, were estimated as follows from Bureau of Reclamation data; copper, $350 \mathrm{~kg} / \mathrm{d}$ and zinc, 1,400 kg/d (Dennis Heiman, Regional Water Quality Control Board, Central Valley Region, written commun., 1998). In perspective, these metal loads were more than twice the combined loads from the 28 next largest inactive mines in northern California and made Iron Mountain the largest discharger of metals to surface waters in the nation (U.S. Environmental Protection Agency, 1992).

Between 1989 and 1994, lime neutralization of the most concentrated adit discharges at Iron Mountain was carried out during three to four months of each wet season. Beginning in November 1994, year-round operation of a lime-neutralization plant has been removing about 85 percent of the copper loads and about 90 percent of the cadmium and zinc loads. The average metal loads leaving Iron Mountain between 1994 and 1997 were estimated to have been $52 \mathrm{~kg}$ copper per day and $45 \mathrm{~kg}$ zinc per day (Dennis Heiman, Regional Water Quality Control Board, Central Valley Region, written commun., 1998). This average copper load is roughly equivalent to the total load of copper from mine discharges into Shasta Lake, as described earlier.

The EPA has issued a Record of Decision (ROD) that mandates additional water treatment at the Iron Mountain site (U.S. Environmental Protection Agency, 1997). Specifically, the ROD calls for construction of a dam along Slickrock Creek, which drains the southwestern slope of Iron Mountain (fig. 2). Estimates by the EPA indicate that the successful implementation of the remediation measures in the 1997 ROD will result in significant additional reduction of copper and zinc loads draining from Iron Mountain in Spring Creek.

\section{Mass Balance and Metal Transport in Keswick Reservoir}

Two different formulations of mass balance are computed using data from this study to evaluate metal transport processes in Keswick Reservoir. The first formulation involves comparison of the sum of two major inputs to the Spring Creek arm of Keswick Reservoir (Spring Creek and Whiskeytown Lake at the Spring Creek Power Plant [SCPP]) with a width- and depth-integrated sample of the Spring Creek arm. The second approach compares inputs and outputs from Keswick Reservoir, using the Spring Creek arm sample to represent the combined contribution of Spring Creek and the SCPP. The various metal loads from Spring Creek arm are combined with the loads from the site below Shasta Dam and Flat Creek (when available) for comparison with the loads from the outfall from Keswick Reservoir below Keswick Dam.

\section{Mass Balance in the Spring Creek Arm of Keswick Reservoir}

A width- and depth-integrated sample was taken in the Spring Creek arm during five of the six sampling periods for this study (all periods except January 1997). Spring Creek itself was sampled during three periods: December 1996, January 1997, and May-June 1997. Whiskeytown Lake was sampled only on two occasions for this study (December 1996 and May-June 1997), and on neither occasion was a colloid sample taken. Nevertheless, a mass balance for the Spring Creek arm was attempted for both the December 1996 and May-June 1997 periods.

Appendix 3 displays seven tables (one for each element of interest-Al, $\mathrm{Cd}, \mathrm{Cu}, \mathrm{Fe}, \mathrm{Pb}, \mathrm{Hg}$, and $\mathrm{Zn}$ ) that document input loads to the Spring Creek arm of Keswick Reservoir in terms of dissolved, colloidal, dissolved plus colloidal, and whole-water (total recoverable) loads. The sum of Spring Creek and Whiskeytown Lake loads is then compared with the actual loads observed in the Spring Creek arm of Keswick Reservoir. The comparisons at the bottom of tables A3-1 through A3-7 in the section "Mass balance, Spring Creek arm" are expressed as percentages of the loads in the Spring Creek arm of Keswick Reservoir. These data indicate that the balance is closer for the May-June 1997 data set than for the December 1996 data set. The balances for iron and aluminum total recoverable whole-water loads using the May-June 1997 data set are approximately 100 percent, suggesting conservative transport of these elements from the mixing zone (where the acid water from Spring Creek mixes into Keswick Reservoir) to the Spring Creek arm sampling point, located only a few hundred meters downstream (see Alpers and others, 2000). However, for reasons outlined earlier in this report, total recoverable concentration data determined from whole-water samples often underrepresent the total load for elements such as iron and aluminum that occur in phases that do not dissolve completely during the total recoverable extraction procedure. The lack of colloid data for the Spring Creek Power Plant input precludes the quantitative analysis of colloid mass balance in this part of the system. 
The "dissolved + colloid" category shows balance factors less than 100 percent for the seven metals considered in detail, on both sets of Spring Creek arm samples (December 1996 and May-June 1997), indicating more output than input on these occasions (Appendix 3). Several explanations for these data are possible: (1) possible additional, unsampled input sources of metals to Keswick Reservoir, (2) remobilization of fine-grained sediments, (3) desorption of metals from fine-grained sediments, (4) sampling under nonsteady-state conditions, and (5) errors in flow measurements. Of these, item 2 is a strong possibility. More than $250,000 \mathrm{yd}^{3}$ of fine-grained, metal-rich sediment have been shown to occur in the Spring Creek arm of Keswick Reservoir (Nordstrom and others, 1999). These sediments have been observed to be mobilized under conditions of fluctuating water levels in Keswick Reservoir and may be scoured by flows from the Spring Creek Power Plant (John Spitzley, CH2M Hill, oral commun., 1998).

\section{Overall Mass Balance in Keswick Reservoir}

Appendix 4 gompares metal load data for inputs to Keswick Reservoir and the outfall from the reservoir at Keswick Dam, with the Spring Creek arm sample used as a proxy for the contributions from Spring Creek and the Spring Creek Power Plant. Aluminum and iron balances are nearly 100 percent for the May-June data set for both whole-water and "dissolved + colloid" loads (tables A4-1 an d A4-4). Balances for trace metals of most environmental concern in Keswick Reservoir (cadmium, copper, and zinc) indicate a range of values both above and below 100 percent. These results indicate the difficulty and uncertainty in computing mass balances from single instantaneous measurements of concentration and discharge. A much more sound approach would be to integrate samples over longer time intervals, such as the duration of a storm event or on a monthly basis. Three of the four sampling periods with adequate data for the instantaneous calculations show apparent copper attenuation (balance values $>100$ percent) despite the fact that iron and aluminum transport for the same periods indicate little to no precipitation of these major elements. The apparent copper attenuation effect could be caused by increased sorption of copper during transport through Keswick Reservoir.

Zinc and cadmium loads for the mass balance behaved quite similarly to each other, the one exception being some apparent attenuation of cadmium more than zinc during November 1996. Both cadmium and zinc were attenuated less than copper, which is consistent with overall patterns of metal transport (figs. 5, 6, 9, 11 12, and 15-18) and their chemical properties (Dzombak and Morel, 1990; Smith, 1999).

An overall hypothesis that is broadly consistent with the data from this study is that the cadmium, copper, and zinc loads at Shasta Dam are roughly half of the corresponding values at Keswick Dam throughout all sampling periods. The contribution from Spring Creek was minimal in July and September 1996, so the Shasta Dam contribution was proportionally higher during these periods; however, the overall pattern of metal loads is consistent with the hypothesis. The instantaneous total (dissolved plus colloidal) copper loads at Shasta Dam ranged from $7 \mathrm{~kg} / \mathrm{d}$ (November 1996) to $180 \mathrm{~kg} / \mathrm{d}$ (December 1996), with no data available for January 1997. Total recoverable (wholewater) loads ranged from $14 \mathrm{~kg} / \mathrm{d}$ to $320 \mathrm{~kg} / \mathrm{d}$. These data are in an appropriate range to be consistent with the Regional Water Board's estimate of $50 \mathrm{~kg} / \mathrm{d}$ for an annualized average copper contribution from the mines above Shasta Lake (Dennis Heiman, Regional Water Quality Control Board, Central Valley Region, written commun., 1998).

\section{Metal Sources Downstream of Keswick Dam}

In this section, spatial variations in metal loads in the Sacramento River are described to identify river reaches with likely metal sources. The discussion is organized into two subsections. The first describes tributaries in the reach between Keswick Dam and Colusa, and the second describes the reach between Colusa and Freeport (including the Yolo Bypass). The second subsection is further subdivided into sections on metal contributions from agricultural drainage and urban runoff.

\section{Tributaries Between Keswick Dam and Colusa}

Although no water samples were collected for this study from tributaries between Keswick Dam and Colusa, the data collected from the mainstem Sacramento River samples clearly indicate that such tributaries and(or) other pollution sources make significant contributions to metal loads in the watershed. Copper and lead loads both increased consistently and substantially between Keswick Dam 
and Colusa during each sampling period; a single exception was an apparent decrease in copper load between Bend Bridge and Colusa during November 1996 (fig.12). In addition, lead isotope data (Alpers and others, 2000) indicate that sources of lead other than the massive sulfide mineralization upstream of Keswick Dam tend to dominate lead transport in the Sacramento River downstream of Bend Bridge, near Red Bluff (fig. 1).

During some sampling periods, the load increases were more dramatic between Keswick Dam and Bend Bridge, and during others, between Bend Bridge and Colusa, suggesting that multiple tributaries are involved and that the nature of the contributions is highly variable and perhaps seasonal in nature. In all cases, the increased copper and lead loads are associated exclusively with colloidal forms as opposed to dissolved metals (figs. 12 ard 14).

A tributary that may be responsible for increasing metal loads between Keswick Dam and Bend Bridge is Cottonwood Creek (fig. 1). Sampling of Cottonwood Creek (at Interstate 5) by the Regional Water Board revealed the following elevated concentrations of total recoverable copper: 16 and 25 $\mu \mathrm{g} / \mathrm{L}$ on April 2, 1996 and June 3, 1996, respectively, with less than 1 to $2 \mu \mathrm{g} / \mathrm{L}$ "dissolved" copper in 0.45- $\mu \mathrm{m}$ filtrates (Regional Water Quality Control Board, Central Valley Region, written commun., 1998). Total recoverable zinc was also elevated in the Cottonwood Creek samples, with concentrations of 24 and $52 \mu \mathrm{g} / \mathrm{L}$, respectively, on the two sampling dates mentioned earlier. Some other tributaries draining the west side of the Sacramento Valley between Redding and Colusa are Clear Creek, Elder Creek, Thomes Creek, and Stoney Creek (some are shown on fig. 1). Very limited water-quality data are available for these creeks, especially during high flow. Additional monitoring on some of these tributaries is planned by the California Department of Water Resources.

Another tributary in this area for which elevated copper concentrations have been reported is Cow Creek, one of several tributaries draining the east side of the Sacramento Valley between Redding and Red Bluff. Samples taken from Cow Creek (at Dersch Road) during April and June, 1996 showed 5.2 and 6 $\mu \mathrm{g} / \mathrm{L}$ of copper, respectively (Regional Water Quality Control Board-Central Valley Region, written commun., 1998). The same samples contained 16 to about $170 \mu \mathrm{g} / \mathrm{L}$ of zinc. Some of the massive sulfide mineralization and inactive/abandoned mines in the
East Shasta mining district (for example, near the town of Ingot, California) are in the Little Cow Creek drainage, a tributary to Cow Creek (Nordstrom and others, 1977; Alpers and others, 2000).

\section{Tributaries Between Colusa and Freeport}

The principal tributaries to the Sacramento River between Colusa and Freeport are agricultural drains such as the Colusa Basin Drain and the Sacramento Slough, and major rivers including the Feather and American rivers. In addition, there are several smaller tributaries that convey urban runoff.

\section{Agricultural Drainage}

Sampling periods in July and September 1996 and in May-June 1997 showed increases of dissolved and colloidal copper loads, and also in colloidal zinc loads in the Sacramento River between Colusa and Verona. This is the reach in which the Colusa Basin Drain and the Sacramento Slough and other agricultural return flows enter the river (fig. 1). Copper transport from rice fields may be significant because large quantities of copper sulfate and other forms of copper are applied from May through June each year to control algae in the flooded fields.

Metal loads from agricultural drainage were evaluated for this study by means of a single sample from the Colusa Basin Drain during rice-field draining in early June 1997. The Colusa Basin Drain is estimated to represent about one-third of the agricultural drainage in the Sacramento Valley. Concentrations of copper in whole-water samples from the Colusa Basin Drain were $16-17 \mu \mathrm{g} / \mathrm{L} ; 0.45-\mu \mathrm{m}$ filtrates had about $3 \mu \mathrm{g} / \mathrm{L}$, and $0.005-\mu \mathrm{g}$-equivalent ultrafiltrates had $1.3 \mu \mathrm{g} / \mathrm{L}$ (Alpers and others, 2000). Dissolved organic carbon was relatively high $(4.8 \mathrm{mg} / \mathrm{L})$ in the water sample from the Colusa Basin Drain, suggesting that the dissolved copper in the ultrafiltrate may be organically complexed. The sequential extraction data indicate that about half of the colloidal copper from the Colusa Basin Drain sample was extracted in the reducible fraction, similar to other samples from the watershed (fig. 18B) and that only a small fraction is oxidizable, sugsestims that any organically complexed copper is not manifested to a great extent in the colloids. However, it is possible that some copper associated with organic matter is removed in the first (reducible) step of the sequential extraction procedure. Additional work would be needed to resolve this point. 
Biweekly monitoring of the Colusa Basin Drain by the NAWQA Program using $0.45-\mu \mathrm{m}$ filtrates showed increased copper concentrations during the growing season relative to the rest of the year, reaching $6 \mu \mathrm{g} / \mathrm{L}$ in May 1996 and 3 to $4 \mu \mathrm{g} / \mathrm{L}$ in June 1997. Copper concentrations in $0.45-\mu \mathrm{m}$ filtrates from the Sacramento Slough reached a maximum of $4 \mu \mathrm{g} / \mathrm{L}$ in December 1996. However, more studies of copper in agricultural drainage are needed before any significant conclusions can be reached.

The total (dissolved plus colloidal) loads of copper from the Colusa Basin Drain in the May-June 1997 sampling period were $18 \mathrm{~kg} / \mathrm{d}$, representing 19 percent of the total copper load at Freeport during that sampling period (ables A1-3 and A2-3). For comparison, the copper loads in the Spring Creek arm of Keswick Reservoir were $20 \mathrm{~kg} / \mathrm{d}$ during the same sampling period, and the total (dissolved plus colloidal) copper load below Keswick Dam was $45 \mathrm{~kg} / \mathrm{d}$, representing 42 percent of the load at Freeport (tables A1-3 and A2-3). In contrast, the copper load of Spring Creek during the January 1997 flood was about $1,100 \mathrm{~kg} / \mathrm{d}$, and the load in the Yolo Bypass was about 7,700 kg/d (table A1-3). On an annual basis, most of copper and zinc loads appear to enter the Sacramento River upriver of Colusa, which is upstream of the influence of most intense agricultural drainage return flows in the Sacramento River watershed. This apparent increase in metal loading is primarily related to the consistent increase in colloid concentration between Bend Bridge and Colusa (figs. 12 and 15), which remains unexplained.

\section{Urban Runoff}

Urban runoff can be an important source of metals to surface waters. For example, the Rhine River at the Dutch-German border contained elevated concentrations of $\mathrm{As}, \mathrm{Cd}, \mathrm{Cr}, \mathrm{Cu}, \mathrm{Pb}, \mathrm{Hg}, \mathrm{Ni}$, and $\mathrm{Zn}$ that were reduced dramatically between 1975 and 1985 (Holland and Petersen, 1995). Awareness is increasing of nonpoint source problems associated with metals in urban settings, such as the use of copper in brake pads.

Although no sampling sites in this study were dedicated to urban runoff, the USGS's NAWQA Program sampled Arcade Creek in the City of Sacramento on a monthly basis for 2 years as an indicator site for urban runoff. Somewhat elevated concentrations of copper, lead, nickel, and zinc were observed in 0.45 - $\mu \mathrm{m}$ filtrates, however metals were not analyzed in unfiltered samples.
Concentration profiles of lead in sediment and lead in colloids shown in the Volume 1 report from this study (Alpers and others, 2000) indicate an increase in lead concentrations downstream of Colusa. The most likely source of this increase is urban runoff, possibly related to atmospheric (wet and dry) deposition. Lead isotope data (Alpers and others, 2000) indicate a distinctly radiogenic source for the colloidal lead sampled from the Sacramento River at Tower Bridge in January 1997. During that high-flow condition, most of the water in the mainstem Sacramento River was derived from the American River, and the majority of the flow from the Sacramento River upstream of Colusa was diverted into the Yolo Bypass. Therefore, the anomalously radiogenic lead isotopes are probably related to granitic source rocks in the American River drainage, although anthropogenic sources for this lead have not been ruled out.

\section{Summary and Conclusions}

The transport of metals in the Sacramento River from Shasta Dam to Freeport was evaluated from July 1996 through June 1997 using an approach that quantified the dissolved and colloidal concentrations and corresponding loads of metals at six sites on the Sacramento River during six sampling periods. Although the water year corresponding to this study was unusual in that most precipitation fell during December and January, a major flood occurred in January, and it was very dry from February to May, so the overall amount of precipitation was close to that expected for a normal year. Most discharge in the river occurred during the 3-month period of December 1996 through February 1997, and a higher proportion of the total annual metal fluxes or loads took place during the same time frame because of the increased transport of suspended sediment and associated higher metal concentrations associated with high flow. In a more typical wet season, the increased discharge and metal fluxes would occur over a longer period, for example December through April or May.

The mineralized area upstream of Keswick Dam is an important source of various metals, especially cadmium, to the lower Sacramento River and the Bay-Delta. This was determined by comparing the metal loads at the sampling site below Keswick Dam with those measured in the Sacramento River at Freeport and the Yolo Bypass. However, it was also determined that the loads, during the period of this 
study, were highly dependent on the flow regime. For example, the proportions of mineralization-related trace-metal loads (percentages representing dissolved plus colloidal loads at Keswick Dam divided by the sum of dissolved and colloidal loads at Freeport and the Yolo Bypass, when flowing) observed during moderately high flows in December 1996 were: cadmium, 87 percent; copper, 35 percent; lead, 10 percent; and zinc, 51 percent. During the flood conditions of early January 1997, the percentages were: cadmium, 22 percent; copper, 11 percent; lead, 2 percent; and zinc, 15 percent. During the irrigation drainage season of May through June 1997, the percentages were: cadmium, 53 percent; copper, 42 percent; lead, 20 percent; and zinc, 75 percent. These estimates must be qualified by the following factors. First, metal loads at Colusa in December 1996 and at Verona in May-June 1997 generally exceeded those determined at Freeport at that time; therefore, the above percentages represent maximum estimates of the proportion of metals from mineralized areas upstream of Keswick Dam. Second, for logistics reasons, the Sacramento River was sampled at Tower Bridge instead of Freeport during January 1997. However, no other significant input of water to the Sacramento River, other than irrigation return flows, occurs between Tower Bridge and Freeport. The results indicate the importance of the mineralized areas for the transport of cadmium, copper, and zinc, but also show that lead must enter the Sacramento River mainly from other areas, as confirmed by lead isotope analyses. The results also indicate that the mineralized areas upstream of Keswick Dam are the source of a significant amount of metals to the lower Sacramento River; however, other areas along the river also must contribute significant amounts especially during extreme high-flow conditions.

The available data suggest that trace-metal loads from agricultural drainage may be significant during the growing season, but that more studies are needed before a definitive conclusion can be reached. Copper transport from rice fields may be significant because large amounts of copper sulfate and other forms of copper are applied from May through June each year to control algae in the flooded fields. Metal loads for sampling periods in July and September 1996 and in May-June 1997 showed increases of dissolved and colloidal copper and also in colloidal zinc in the
Sacramento River between Colusa and Verona, the river reach along which the Colusa Basin Drain and the Sacramento Slough and other agricultural return flows enter the river. Also, water-quality sampling by the NAWQA Program shows that copper concentrations in $0.45 \mu \mathrm{m}$-filtered water samples from the Colusa Basin Drain are elevated during the period of copper application to the fields relative to the rest of the year. To put the copper loads associated with agricultural drainage in perspective, the total (dissolved plus colloidal) loads of copper from the Colusa Basin Drain in June 1997 were 18 kg/d, representing about 19 percent of the total copper load at Freeport, whereas the copper loads from Iron Mountain by way of the Spring Creek arm of Keswick Reservoir were $20 \mathrm{~kg} / \mathrm{d}$ during the same sampling period, and the copper load below Keswick Dam represented about 42 percent of the total (dissolved plus colloidal) copper load at Freeport. In contrast to these relatively low-flow conditions, the copper load of Spring Creek during the January 1997 flood was about $1,100 \mathrm{~kg} / \mathrm{d}$ and the copper load in the Yolo Bypass was about 7,700 kg/d. On an annual basis, most of copper and zinc loads appear to enter the Sacramento River upriver of Colusa, which is upstream of the influence of most intense agricultural drainage return flows in the Sacramento River watershed. Some of the metal loads are clearly from well known, mining-related sources of cadmium, copper, and zinc above Keswick Dam; however, large increases in metal loads associated with elevated colloid concentrations at Colusa remain unexplained.

This study has demonstrated that some trace metals of environmental significance (cadmium, copper, and zinc) in the Sacramento River are transported largely in dissolved form at upstream sites (below Shasta Dam, below Keswick Dam, and at Bend Bridge) proximal to the mineralized areas of the West Shasta and East Shasta mining districts. Despite continuous water treatment that has removed 85 to 90 percent of the cadmium, copper, and zinc from the mine drainage at Iron Mountain since 1994, Spring Creek remains an important source of these metals to the Sacramento River system. In the acidic water of Spring Creek, cadmium, copper, and zinc are transported almost exclusively in dissolved form. In contrast, these trace metals are transported largely in colloidal form at downstream sites (Colusa, Verona, 
Freeport, and Yolo Bypass). Aluminum, iron, and lead were observed to be transported predominantly in the colloidal phase at all mainstem Sacramento River sampling sites during all sampling periods in this study.

Speciation of metals on the colloid particles, which is based on sequential chemical extractions, showed that metals are variably distributed among reducible, oxidizable, and residual phases. Further research is needed to address the biological significance of metals associated with these phases in the Sacramento River system.

\section{References Cited}

Albers, J.P., 1985, Geology of the Brick Flat massive sulfide body, Iron Mountain cluster, West Shasta District, California. Economic Geology, v. 80, p. 2092-2099.

Albers, J.P., and Bain, J.H.C., 1985, Regional setting and new information on some critical geologic features of the West Shasta District, California: Economic Geology, v. 80, p. 2072-2091.

Alpers, C.N., Taylor, H.E., and Domagalski, J.L., editors, 2000, Metal transport in the Sacramento River, California, 1996-97: Volume 1. Methods and Data: U.S. Geological Survey Water-Resources Investigations Report 99-4286, 430 p.

Anderson, S.W., Rockwell, G.L., Friebel, M.F., and Webster, M.D., 1997, Water resources data-California, water year 1996. Volume 4. Northern Central Valley Basins and the Great Basin from Honey Lake Basin to Oregon State Line: U.S. Geological Survey Water-Data Report CA-97-4, 469 p.

Cain, D.J., Carter, J.L., Fend, S.V, Luoma, S.N., Alpers, C.N., and Taylor, H.E., 2000, Metal exposure to a benthic invertebrate, Hydropsyche californica, related to mine drainage in the Sacramento River: Canadian Journal of Fisheries and Aquatic Sciences, v. 57, p. 380-390.

California State Water Resources Control Board, 1992, Water Quality Assessment for 1992: Sacramento, Calif., California Environmental Protection Agency, State Water Resources Control Board.

Church, S.E., Kimball, B.A., Fey, D.L., Ferderer, D.A., Yager, T.J., and Vaughn, R.B., 1997, Source, transport, and partitioning of metals between water, colloids, and bed sediments, of the Animas River, Colorado: U.S. Geological Survey Open-File Report 97-151, 135 p.
Clarke, F.W., 1924, The data of geochemistry (5th ed.): U.S. Geological Survey Bulletin 770, 841 p.

Clark, S., and Connor, V.M., 1999, Metal concentrations, loads and toxicity assessments in the Sacramento-San Joaquin Delta estuary, 1993-1995: Sacramento, Calif., California Environmental Protection Agency, State Water Resources Control Board, Central Valley Region.

Connor, V.M., Deanovic, L.A., and Reyes, E.L., 1994, Central Valley Regional Water Quality Control Board Basin Plan, Metal Implementation Plan Development Project: Bioassay Results: 1991-92, Final Report: Sacramento, Calif., California Environmental Protection Agency, State Water Resources Control Board, Central Valley Region.

Coston, J.A., Davis, J.A., and Alpers, C.N., 1998, Partitioning of $\mathrm{Cd}, \mathrm{Cu}$, and $\mathrm{Zn}$ onto sediments associated with acid mine drainage, Iron Mountain, Shasta County, California: Eos, Transactions, American Geophysical Union, v. 79, no., 45, p. F314.

Domagalski, J.L., Knifong, D.L, MacCoy, D.E., Dileanis, P.D., Dawson, B.J., and Majewski, M.S., 1998, Water quality assessment of the Sacramento River Basin, California: Environmental setting and study design: U.S. Geological Survey Water-Resources Investigations Report 97-4254, $31 \mathrm{p}$.

Dzombak, D.A., and Morel, F.M.M., 1990, Surface complexation modeling: Hydrous ferric oxide. New York, John Wiley, 393 p.

Franklin, J.M., Hannington, M.D., Jonasson, I.R., and Barrie, C.T., 1998, Arc-related volcanogenic massive sulfide deposits, in Metallogeny of volcanogenic arcs: Victoria, British Columbia, Geological Survey Branch, Open File Series 1998-8, chap. N.

Hamlin, S.N., and Alpers, C.N., 1996, Hydrogeology and geochemistry of acid mine drainage in ground water in the vicinity of Penn Mine and Camanche Reservoir, Calaveras County, California: Second-year summary, 1992-93: U.S. Geological Survey Water-Resources Investigations Report 96-4257, 44 p.

Holland, H.D., and Petersen, Ulrich, 1995, Living dangerously: The earth, its resources and the environment: Princeton, N.J., Princeton University Press, 490 p.

Hunrichs, R.A., Pratt, D.A., and Meyer, R.W., 1998, Magnitude and frequency of the floods of January 1997 in northern and central California, preliminary determinations: U.S. Geological Survey Open-File Report 98-626, $120 \mathrm{p}$.

Kimball, B.A., Callender, E., and Axtmann, E.V., 1995, Effects of colloids on metal transport in a river receiving acid mine drainage, upper Arkansas River, Colorado, U.S.A.: Applied Geochemistry, v. 10, no. 3, p. 285-306. 
Larry Walker Associates and Brown and Caldwell, 1994, Sacramento Coordinated Water Quality Monitoring Program: 1993 annual report: Sacramento, Calif., Sacramento Coordinated Water Quality Monitoring Program.

Larsen, Karen, 1998, Sacramento River Watershed Project, Toxicity Monitoring Results, 1997-98. Final report: Sacramento, Calif., Sacramento Regional Sanitation District, 215 p.

Larsen, Karen, Connor, Valerie, Deanovic, L., and Hinton, D.E., 1998, Sacramento River Watershed Project, Toxicity Monitoring Results, 1996-97: Sacramento, Calif., California Environmental Protection Agency, State Water Resources Control Board, Central Valley Region.

Millipore Corporation, 1993, Selecting a membrane for concentration, desalting, and buffer exchange of macromolecules (ultrafiltration): Bedford, Mass., Millipore Corporation.

Nordstrom, D.K., and Alpers, C.N., 1995, Remedial investigations, decisions, and geochemical consequences at Iron Mountain Mine, California, in Hynes, T.P., and Blanchette, M.C., eds., Sudbury '95: Mining and the Environment: Sudbury, Canada, May 28-June 1, 1995. Conference proceedings: Sudbury, Ontario, Canada, Laurentian University, v. 2, p. 633-642.

- - - 1999a, Geochemistry of acid mine waters, in Plumlee, G.S., and Logsdon, M.J., eds., Processes, methods, and health issues, pt. A of The Environmental geochemistry of mineral deposits: Littelton, Colo., Society of Economic Geologists, Reviews in Economic Geology series, v. 6A, p. 133-160.

_ $-1999 \mathrm{~b}$, Negative $\mathrm{pH}$, efflorescent mineralogy, and consequences for environmental restoration at the Iron Mountain Superfund site, California, in Smith, J.V., ed., Colloquium on geology, mineralogy, and human welfare: Proceedings of the National Academy of Sciences of the United States of America, v. 96, p. 3455-3462.

Nordstrom, D.K., Alpers, C.N., and Ball, J.W, 1991, Measurement of negative $\mathrm{pH}$ and high metal concentrations in extremely acid mine water from Iron Mountain, California [abs.]: Geological Society of America Abstracts with Programs, v. 23, no. 5, p. A383.

Nordstrom, D.K., Alpers, C.N., Coston, J.A., Taylor, H.E., McCleskey, R.B., Ball, J.W., Ogle, S., Cotsifas, J.S., and Davis, J.A., 1999, Geochemistry, toxicity, and sorption properties of contaminated sediments and pore waters from two reservoirs receiving mine drainage, in Morganwalp, D.W., and Buxton, H.T., eds., U.S. Geological Survey Toxic Substances Hydrology Program-Proceedings of the technical meeting, Charleston, South Carolina, March 8-12,
1999: U.S. Geological Survey Water-Resources Investigations Report 99-4018-A, p. 289-296.

Nordstrom, D.K., Alpers, C.N., Ptacek, C.J., and Blowes, D.W., 2000, Negative $\mathrm{pH}$ and extremely acidic mine waters from Iron Mountain, California: Environmental Science \& Technology, v. 34, no. 2., p. 254-258.

Nordstrom, D.K., Jenne, E.A., and Averett, R. C., 1977, Heavy metal discharges into Shasta Lake and Keswick Reservoir on the upper Sacramento River, California: A reconnaissance during low flow: U.S. Geological Survey Open-File Report, 76-49, 25 p.

Rantz, S.E., and others, 1982, Measurement and computation of stream flow: Volume 1. Measurement of stage and discharge: U.S. Geological Survey Water-Supply Paper 2175, 284 p.

Rockwell, G.L., Friebel, M.F., Webster, M.D., and Anderson, S.W., 1998, Water resources dataCalifornia, water year 1997. Volume 4. Northern Central Valley Basins and the Great Basin from Honey Lake Basin to Oregon State Line: U.S. Geological Survey Water-Data Report CA-98-4, 456 p.

Sauer, V.B., and Meyer, R.W., 1992, Determination of error in individual discharge measurements: U.S. Geological Survey Open-File Report 92-144, 21 p.

Seal, R.R.II, Hammarstrom, J.M., Foley, N.K., and Alpers, C.N., in press, Geoenvironmental models for seafloor base-and precious-metal massive sulfide deposits, in International Conference on Acid Rock Drainage 2000, May 21-24, 2000, Denver, Colo.

Smith, K.S., 1999, Metal sorption on mineral surfaces: An overview with examples relating to mineral deposits, in Plumlee, G.S., and Logsdon, M.J., eds., Processes, methods, and health issues, pt. A of The environmental geochemistry of mineral deposits: Littelton, Colo., Society of Economic Geologists, Reviews in Economic Geology series, v. 6A, p. 161-182.

Stumm, Werner, and Morgan, J.J., 1996, Aquatic chemistry: Chemical equilibria and rates in natural waters (3rd ed.): New York, John Wiley, Environmental Science and Technology series, 1,022 p.

U.S. Environmental Protection Agency, 1992, Public comment environmental endangerment assessment, Iron Mountain Mine, Redding, California: Prepared by CH2M Hill, Redding, California, for the U.S. Environmental Protection Agency.

- - - 1997, Superfund record of decision: Iron Mountain Mine, Redding, CA.: U.S. Environmental Protection Agency, Office of Emergency and Remedial Response, EPA/541-R-97/132, variously paged.

Webster, J.G., Swedlund, P.J., and Webster, K.S., 1998, Trace metal adsorption onto an acid mine drainage iron(III) oxyhydroxysulfate: Environmental Science and Technology, v. 32, no. 10, p. 1361-1368. 


\section{Appendix 1. Tables of Data Comparing Metal Loads in Dissolved Form, Colloidal Form, and Whole Water}

Table A1-1. Aluminum loads derived from concentrations in dissolved, colloid, and whole water samples

Table A1-2. Cadmium loads derived from concentrations in dissolved, colloid, and whole water samples

Table A1-3. Copper loads derived from concentrations in dissolved, colloid, and whole water samples

Table A1-4. Iron loads derived from concentrations in dissolved, colloid, and whole water samples

Table A1-5. Lead loads derived from concentrations in dissolved, colloid, and whole water samples

Table A1-6. Mercury loads derived from concentrations in dissolved, colloid, and whole water samples

Table A1-7. Zinc loads derived from concentrations in dissolved, colloid, and whole water samples 
Table A1-1. Aluminum loads derived from concentrations in dissolved, colloid, and whole water samples

[Loads in kilograms per day; Br., Bridge; Cr., Creek; NA, not analyzed; NC, not calculated; Sac., Sacramento; SCPP, Spring Creek Power Plant; R., River; TR, total recoverable analysis. $\geq$, load is greater than or equal to value shown because of incomplete digestion of colloid sample]

\begin{tabular}{|c|c|c|c|c|c|c|c|}
\hline \multirow[b]{2}{*}{ Site } & & \multicolumn{6}{|c|}{ Sampling Periods } \\
\hline & & $\begin{array}{l}\text { July } \\
1996\end{array}$ & $\begin{array}{l}\text { Sept. } \\
1996\end{array}$ & $\begin{array}{l}\text { Nov. } \\
1996\end{array}$ & $\begin{array}{l}\text { Dec. } \\
1996\end{array}$ & $\begin{array}{l}\text { Jan. } \\
1997\end{array}$ & $\begin{array}{c}\text { May-June } \\
1997\end{array}$ \\
\hline \multirow[t]{4}{*}{ Sac R.-Shasta } & Dissolved & 48 & 33 & 10 & 400 & NA & 27 \\
\hline & Colloid & 7,300 & NA & 780 & $\geq 11,000$ & NA & 15,000 \\
\hline & Dissolved + Colloid & 7,300 & $\mathrm{NC}$ & 790 & $\geq 11,000$ & $\mathrm{NC}$ & 15,000 \\
\hline & Whole Water, TR & 5,900 & 1,500 & 550 & 7,400 & NA & 6,500 \\
\hline \multirow[t]{4}{*}{ Sac R.-Keswick } & Dissolved & 75 & 120 & 140 & 1,700 & 1,300 & 100 \\
\hline & Colloid & 7,700 & NA & 4200 & 18,000 & 94,000 & 22,000 \\
\hline & Dissolved + Colloid & 7,800 & $\mathrm{NC}$ & 4,300 & 20,000 & 95,000 & 22,000 \\
\hline & Whole Water, TR & 6,200 & 1,700 & 3,000 & 14,000 & 62,000 & 9,400 \\
\hline \multirow[t]{4}{*}{ Sac R.-Bend Br. } & Dissolved & 77 & 60 & 130 & 1,000 & 880 & 89 \\
\hline & Colloid & 10,000 & 4,400 & 14,000 & 280,000 & $2,100,000$ & 23,000 \\
\hline & Dissolved + Colloid & 10,000 & 4,400 & 15,000 & 280,000 & $2,100,000$ & 23,000 \\
\hline & Whole Water, TR & 8,400 & 3,300 & 10,000 & 190,000 & $1,300,000$ & 10,000 \\
\hline \multirow[t]{4}{*}{ Sac R.-Colusa } & Dissolved & NA & 34 & 24 & 310 & 540 & 51 \\
\hline & Colloid & 92,000 & 18,000 & 22,000 & 420,000 & $4,100,000$ & 50,000 \\
\hline & Dissolved + Colloid & NA & 18,000 & 22,000 & 420,000 & $4,100,000$ & 50,000 \\
\hline & Whole Water, TR & 74,000 & 13,000 & 15,000 & 280,000 & $2,600,000$ & 21,000 \\
\hline \multirow[t]{4}{*}{ Sac R.-Verona } & Dissolved & 120 & 41 & NA & 300 & NA & 44 \\
\hline & Colloid & 60,000 & 79,000 & 40,000 & 390,000 & NA & 76,000 \\
\hline & Dissolved + Colloid & 60,000 & 79,000 & NA & 390,000 & $\mathrm{NC}$ & 76,000 \\
\hline & Whole Water, TR & 48,000 & 58,000 & 28,000 & 260,000 & NA & 31,000 \\
\hline \multirow[t]{4}{*}{ Sac R.-Freeport } & Dissolved & 110 & 41 & 25 & 620 & ${ }^{1} 1,500$ & 63 \\
\hline & Colloid & $\geq 58,000$ & $\geq 33,000$ & 15,000 & 550,000 & ${ }^{1} 3,700,000$ & 63,000 \\
\hline & Dissolved + Colloid & $\geq 58,000$ & $\geq 33,000$ & 15,000 & 550,000 & ${ }^{1} 3,700,000$ & 63,000 \\
\hline & Whole Water, TR & 46,000 & 24,000 & 10,000 & 370,000 & ${ }^{1} 2,300,000$ & 26,000 \\
\hline \multirow[t]{4}{*}{ Flat Cr. } & Dissolved & NA & NA & NA & 0.83 & NA & 0.0039 \\
\hline & Colloid & NA & NA & NA & NA & NA & NA \\
\hline & Dissolved + Colloid & $\mathrm{NC}$ & $\mathrm{NC}$ & $\mathrm{NC}$ & $\mathrm{NC}$ & $\mathrm{NC}$ & $\mathrm{NC}$ \\
\hline & Whole Water, TR & NA & NA & NA & 8.8 & NA & 0.017 \\
\hline \multirow[t]{4}{*}{ Spring Cr.-Weir } & Dissolved & NA & NA & NA & 1,200 & NA & 97 \\
\hline & Colloid & NA & NA & NA & 290 & NA & 84 \\
\hline & Dissolved + Colloid & $\mathrm{NC}$ & $\mathrm{NC}$ & $\mathrm{NC}$ & 1,500 & $\mathrm{NC}$ & 180 \\
\hline & Whole Water, TR & NA & NA & NA & 1,400 & NA & 130 \\
\hline \multirow[t]{4}{*}{ Spring Cr.-Road } & Dissolved & NA & NA & NA & NA & 4,200 & NA \\
\hline & Colloid & NA & NA & NA & NA & 2,000 & NA \\
\hline & Dissolved + Colloid & $\mathrm{NC}$ & $\mathrm{NC}$ & $\mathrm{NC}$ & $\mathrm{NC}$ & 6,200 & $\mathrm{NC}$ \\
\hline & Whole Water, TR & NA & NA & NA & NA & 5,500 & NA \\
\hline \multirow{4}{*}{$\begin{array}{l}\text { Whiskeytown } \\
\text { Lake at SCPP }\end{array}$} & Dissolved & NA & NA & NA & 21 & NA & 16 \\
\hline & Colloid & NA & NA & NA & NA & NA & NA \\
\hline & Dissolved + Colloid & $\mathrm{NC}$ & $\mathrm{NC}$ & $\mathrm{NC}$ & $\mathrm{NC}$ & $\mathrm{NC}$ & $\mathrm{NC}$ \\
\hline & Whole Water, TR & NA & NA & NA & 310 & NA & 2,800 \\
\hline \multirow[t]{4}{*}{ Spring Cr. arm } & Dissolved & 25 & 46 & 130 & 580 & NA & 82 \\
\hline & Colloid & 130 & NA & 860 & 4,600 & NA & 6,600 \\
\hline & Dissolved + Colloid & 160 & $\mathrm{NC}$ & 990 & 5,100 & $\mathrm{NC}$ & 6,600 \\
\hline & Whole Water, TR & 130 & 190 & 720 & 3,600 & NA & 2,900 \\
\hline
\end{tabular}


Table A1-1. Aluminum loads derived from concentrations in dissolved, colloid, and whole water samples—Continued

\begin{tabular}{|c|c|c|c|c|c|c|c|}
\hline \multirow[b]{2}{*}{ Site } & & \multicolumn{6}{|c|}{ Sampling Periods } \\
\hline & & $\begin{array}{l}\text { July } \\
1996\end{array}$ & $\begin{array}{l}\text { Sept. } \\
1996\end{array}$ & $\begin{array}{l}\text { Nov. } \\
1996\end{array}$ & $\begin{array}{l}\text { Dec. } \\
1996\end{array}$ & $\begin{array}{l}\text { Jan. } \\
1997\end{array}$ & $\begin{array}{c}\text { May-June } \\
1997\end{array}$ \\
\hline Colusa Basin & Dissolved & $\mathrm{NA}$ & NA & NA & NA & NA & 1 \\
\hline \multirow[t]{3}{*}{ Drain } & Colloid & NA & NA & NA & NA & NA & 16,000 \\
\hline & Dissolved + Colloid & $\mathrm{NC}$ & $\mathrm{NC}$ & $\mathrm{NC}$ & $\mathrm{NC}$ & $\mathrm{NC}$ & 16,000 \\
\hline & Whole Water, TR & NA & NA & NA & NA & NA & 6,500 \\
\hline \multirow[t]{4}{*}{ Yolo Bypass } & Dissolved & NA & NA & NA & NA & 1,100 & NA \\
\hline & Colloid & NA & NA & NA & NA & $5,600,000$ & NA \\
\hline & Dissolved + Colloid & $\mathrm{NC}$ & $\mathrm{NC}$ & $\mathrm{NC}$ & $\mathrm{NC}$ & $5,600,000$ & $\mathrm{NC}$ \\
\hline & Whole Water, TR & NA & NA & NA & NA & $3,600,000$ & NA \\
\hline Freeport + Yolo & Dissolved & 110 & 41 & 25 & 620 & 2,600 & 63 \\
\hline \multirow[t]{3}{*}{ Bypass } & Colloid & 58,000 & 33,000 & 15,000 & 550,000 & $9,300,000$ & 63,000 \\
\hline & Dissolved + Colloid & 58,000 & 33,000 & 15,000 & 551,000 & $9,300,000$ & 63,000 \\
\hline & Whole Water, TR & 46,000 & 24,000 & 10,000 & 370,000 & $5,900,000$ & 26,000 \\
\hline
\end{tabular}

${ }^{1}$ Samples collected at Tower Bridge in January 1997. 
Table A1-2. Cadmium loads derived from concentrations in dissolved, colloid, and whole water samples

[Loads in grams per day; Br., Bridge; Cr., Creek; NA, not analyzed; NC, not calculated; R., River; Sac., Sacramento; SCPP, Spring Creek Power Plant; TR, total recoverable analysis. $\leq$, load is less than or equal to value shown because of concentration less than detection limit; $\geq$, load is greater than or equal to value shown because of incomplete digestion of colloid sample]

\begin{tabular}{|c|c|c|c|c|c|c|c|}
\hline \multirow{2}{*}{ Site } & & \multicolumn{6}{|c|}{ Sampling Periods } \\
\hline & & $\begin{array}{l}\text { July } \\
1996\end{array}$ & $\begin{array}{l}\text { Sept. } \\
1996\end{array}$ & $\begin{array}{l}\text { Nov. } \\
1996\end{array}$ & $\begin{array}{l}\text { Dec. } \\
1996\end{array}$ & $\begin{array}{l}\text { Jan. } \\
1997\end{array}$ & $\begin{array}{c}\text { May-June } \\
1997\end{array}$ \\
\hline \multirow[t]{4}{*}{ Sac R.-Shasta } & Dissolved & 570 & 370 & 60 & 2,600 & NA & $\leq 96$ \\
\hline & Colloid & 190 & NA & 59 & $\geq 320$ & NA & 140 \\
\hline & Dissolved + Colloid & 760 & $\mathrm{NC}$ & 120 & $\geq 2,900$ & $\mathrm{NC}$ & $\leq 230$ \\
\hline & Whole Water, TR & 960 & 650 & 160 & 5,400 & NA & 390 \\
\hline \multirow[t]{4}{*}{ Sac R.-Keswick } & Dissolved & 580 & 410 & 500 & 4,400 & 8,800 & 290 \\
\hline & Colloid & 340 & NA & 220 & 980 & 6,300 & 260 \\
\hline & Dissolved + Colloid & 910 & $\mathrm{NC}$ & 720 & 5,300 & 15,000 & 550 \\
\hline & Whole Water, TR & 1,000 & 730 & 1,200 & 8,300 & 21,000 & 530 \\
\hline \multirow[t]{4}{*}{ Sac R.-Bend Br. } & Dissolved & 800 & 340 & 380 & 2,100 & 1,200 & 130 \\
\hline & Colloid & 390 & 78 & 380 & 4,500 & 23,000 & 270 \\
\hline & Dissolved + Colloid & 1,200 & 420 & 760 & 6,600 & 24,000 & 410 \\
\hline & Whole Water, TR & 1,200 & 690 & 1,200 & 9,200 & 25,000 & 860 \\
\hline \multirow[t]{4}{*}{ Sac R.-Colusa } & Dissolved & NA & 150 & 87 & 420 & 530 & $\leq 160$ \\
\hline & Colloid & 2,300 & 690 & 860 & 7,800 & 29,000 & 710 \\
\hline & Dissolved + Colloid & NA & 840 & 950 & 8,200 & 30,000 & $\leq 870$ \\
\hline & Whole Water, TR & 1,900 & 780 & 450 & 7,800 & 26,000 & 710 \\
\hline \multirow[t]{4}{*}{ Sac R.-Verona } & Dissolved & $\leq 200$ & 250 & NA & 650 & NA & $\leq 210$ \\
\hline & Colloid & 2,400 & 1,400 & 910 & 6,000 & NA & 870 \\
\hline & Dissolved + Colloid & $\leq 2,600$ & 1,600 & $\mathrm{NC}$ & 6,700 & $\mathrm{NC}$ & $\leq 1,100$ \\
\hline & Whole Water, TR & 2,200 & 1,500 & 860 & 6,100 & NA & 1,000 \\
\hline \multirow[t]{4}{*}{ Sac R.-Freeport } & Dissolved & 420 & $\leq 190$ & $\leq 160$ & 720 & ${ }^{1} \leq 1,100$ & $\leq 260$ \\
\hline & Colloid & $\geq 2,900$ & $\geq 4,300$ & 220 & 5,200 & ${ }^{1} 19,000$ & 770 \\
\hline & Dissolved + Colloid & $\geq 3,300$ & $\geq 4,500$ & $\leq 380$ & 5,900 & ${ }^{1} \leq 20,000$ & $\leq 1,000$ \\
\hline & Whole Water, TR & 2,000 & 990 & 600 & 10,000 & ${ }^{1} 17,000$ & 840 \\
\hline \multirow[t]{4}{*}{ Flat Cr. } & Dissolved & NA & NA & NA & 3.8 & NA & 0.18 \\
\hline & Colloid & NA & NA & NA & NA & NA & NA \\
\hline & Dissolved + Colloid & $\mathrm{NC}$ & $\mathrm{NC}$ & $\mathrm{NC}$ & $\mathrm{NC}$ & $\mathrm{NC}$ & $\mathrm{NC}$ \\
\hline & Whole Water, TR & NA & NA & NA & 5.0 & NA & 0.31 \\
\hline \multirow[t]{4}{*}{ Spring Cr.-Weir } & Dissolved & NA & NA & NA & 1,700 & NA & 140 \\
\hline & Colloid & NA & NA & NA & 4.2 & NA & 1.3 \\
\hline & Dissolved + Colloid & $\mathrm{NC}$ & $\mathrm{NC}$ & $\mathrm{NC}$ & 1,700 & $\mathrm{NC}$ & 150 \\
\hline & Whole Water, TR & NA & NA & NA & 1,800 & NA & 160 \\
\hline \multirow[t]{4}{*}{ Spring Cr.-Road } & Dissolved & NA & NA & NA & NA & 18,000 & NA \\
\hline & Colloid & NA & NA & NA & NA & 16 & NA \\
\hline & Dissolved + Colloid & $\mathrm{NC}$ & $\mathrm{NC}$ & $\mathrm{NC}$ & $\mathrm{NC}$ & 18,000 & $\mathrm{NC}$ \\
\hline & Whole Water, TR & NA & NA & NA & NA & 17,000 & NA \\
\hline \multirow{4}{*}{$\begin{array}{l}\text { Whiskeytown } \\
\text { Lake at SCPP }\end{array}$} & Dissolved & NA & NA & NA & 84 & NA & $\leq 27$ \\
\hline & Colloid & NA & NA & NA & NA & NA & NA \\
\hline & Dissolved + Colloid & $\mathrm{NC}$ & $\mathrm{NC}$ & $\mathrm{NC}$ & $\mathrm{NC}$ & $\mathrm{NC}$ & $\mathrm{NC}$ \\
\hline & Whole Water, TR & NA & NA & NA & $\leq 93$ & NA & 88 \\
\hline \multirow[t]{4}{*}{ Spring Cr. arm } & Dissolved & 73 & 68 & 310 & 3,200 & NA & 110 \\
\hline & Colloid & 10 & NA & 56 & 540 & NA & 89 \\
\hline & Dissolved + Colloid & 83 & $\mathrm{NC}$ & 370 & 3,800 & $\mathrm{NC}$ & 200 \\
\hline & Whole Water, TR & $\leq 59$ & 130 & 510 & 4,800 & NA & 270 \\
\hline
\end{tabular}


Table A1-2. Cadmium loads derived from concentrations in dissolved, colloid, and whole water samples-Continued

\begin{tabular}{|c|c|c|c|c|c|c|c|}
\hline \multirow[b]{2}{*}{ Site } & & \multicolumn{6}{|c|}{ Sampling Periods } \\
\hline & & $\begin{array}{l}\text { July } \\
1996\end{array}$ & $\begin{array}{l}\text { Sept. } \\
1996\end{array}$ & $\begin{array}{l}\text { Nov. } \\
1996\end{array}$ & $\begin{array}{l}\text { Dec. } \\
1996\end{array}$ & $\begin{array}{l}\text { Jan. } \\
1997\end{array}$ & $\begin{array}{c}\text { May-June } \\
1997\end{array}$ \\
\hline \multirow[t]{4}{*}{ Colusa Basin Drain } & Dissolved & NA & NA & NA & NA & NA & $\leq 7$ \\
\hline & Colloid & NA & NA & NA & NA & NA & 86 \\
\hline & Dissolved + Colloid & $\mathrm{NC}$ & $\mathrm{NC}$ & $\mathrm{NC}$ & $\mathrm{NC}$ & $\mathrm{NC}$ & $\leq 94$ \\
\hline & Whole Water, TR & NA & NA & NA & NA & NA & 55 \\
\hline \multirow[t]{4}{*}{ Yolo Bypass } & Dissolved & NA & NA & NA & NA & 1,600 & NA \\
\hline & Colloid & NA & NA & NA & NA & 45,000 & NA \\
\hline & Dissolved + Colloid & $\mathrm{NC}$ & $\mathrm{NC}$ & $\mathrm{NC}$ & $\mathrm{NC}$ & 47,000 & $\mathrm{NC}$ \\
\hline & Whole Water, TR & NA & NA & NA & NA & 39,000 & NA \\
\hline \multirow{4}{*}{$\begin{array}{l}\text { Freeport + Yolo } \\
\text { Bypass }\end{array}$} & Dissolved & 420 & 240 & 160 & 900 & $\leq 3,000$ & 260 \\
\hline & Colloid & 2,900 & 4,300 & 220 & 5,200 & 64,000 & 770 \\
\hline & Dissolved + Colloid & 3,300 & 4,500 & 380 & 6,100 & $\leq 67,000$ & 1,000 \\
\hline & Whole Water, TR & 2,000 & 990 & 600 & 10,000 & 56,000 & 840 \\
\hline
\end{tabular}

${ }^{1}$ Samples collected at Tower Bridge in January 1997. 
Table A1-3. Copper loads derived from concentrations in dissolved, colloid, and whole water samples

[Loads in kilograms per day; Br., Bridge; Cr., Creek; NA, not analyzed; NC, not calculated; R., River; Sac., Sacramento; SCPP, Spring Creek Power Plant; TR, total recoverable analysis. $\leq$, load is less than or equal to value shown because of concentration less than detection limit; $\geq$, load is greater than or equal to value shown because of incomplete digestion of colloid sample]

\begin{tabular}{|c|c|c|c|c|c|c|c|}
\hline \multirow[b]{2}{*}{ Site } & & \multicolumn{6}{|c|}{ Sampling Periods } \\
\hline & & $\begin{array}{l}\text { July } \\
1996\end{array}$ & $\begin{array}{l}\text { Sept. } \\
1996\end{array}$ & $\begin{array}{l}\text { Nov. } \\
1996\end{array}$ & $\begin{array}{l}\text { Dec. } \\
1996\end{array}$ & $\begin{array}{l}\text { Jan. } \\
1997\end{array}$ & $\begin{array}{c}\text { May-June } \\
1997\end{array}$ \\
\hline \multirow[t]{4}{*}{ Sac R.-Shasta } & Dissolved & 30 & 10 & 4.3 & 87 & NA & 5.6 \\
\hline & Colloid & 15 & NA & 2.7 & $\geq 95$ & $\mathrm{NA}$ & 18 \\
\hline & Dissolved + Colloid & 44 & $\mathrm{NC}$ & 7.0 & $\geq 180$ & $\mathrm{NC}$ & 24 \\
\hline & Whole Water, TR & 55 & 27 & 14 & 320 & NA & 27 \\
\hline \multirow[t]{4}{*}{ Sac R.-Keswick } & Dissolved & 29 & 12 & 9.2 & 130 & 260 & 14 \\
\hline & Colloid & 15 & NA & 22 & 180 & 1,000 & 31 \\
\hline & Dissolved + Colloid & 43 & $\mathrm{NC}$ & 31 & 310 & 1,300 & 45 \\
\hline & Whole Water, TR & 56 & 40 & 56 & 670 & 1,400 & 48 \\
\hline \multirow[t]{4}{*}{ Sac R.-Bend Br. } & Dissolved & 32 & 7.7 & 11 & 92 & 230 & 14 \\
\hline & Colloid & 28 & 7.8 & 100 & 640 & 3,500 & 34 \\
\hline & Dissolved + Colloid & 61 & 15 & 110 & 730 & 3,700 & 49 \\
\hline & Whole Water, TR & 63 & 43 & 80 & 870 & 3,200 & 55 \\
\hline \multirow[t]{4}{*}{ Sac R.-Colusa } & Dissolved & NA & 12 & 8.5 & 46 & 170 & 16 \\
\hline & Colloid & 230 & 76 & 64 & 1,200 & 4,700 & 71 \\
\hline & Dissolved + Colloid & NA & 89 & 72 & 1,200 & 4,800 & 86 \\
\hline & Whole Water, TR & 140 & 64 & 39 & 820 & 4,300 & 75 \\
\hline \multirow[t]{4}{*}{ Sac R.-Verona } & Dissolved & 31 & 22 & NA & 120 & NA & 15 \\
\hline & Colloid & 280 & 180 & 91 & 930 & NA & 99 \\
\hline & Dissolved + Colloid & 310 & 200 & $\mathrm{NC}$ & 1,100 & $\mathrm{NC}$ & 110 \\
\hline & Whole Water, TR & 130 & 140 & 87 & 720 & $\mathrm{NA}$ & 110 \\
\hline \multirow[t]{4}{*}{ Sac R.-Freeport } & Dissolved & 39 & 15 & 12 & 140 & ${ }^{1} 280$ & 16 \\
\hline & Colloid & $\geq 290$ & $\geq 220$ & 26 & 740 & ${ }^{1} 4,000$ & 91 \\
\hline & Dissolved + Colloid & $\geq 330$ & $\geq 230$ & 37 & 880 & ${ }^{1} 4,300$ & 110 \\
\hline & Whole Water, TR & 130 & 88 & 68 & 930 & ${ }^{1} 3,200$ & 91 \\
\hline \multirow[t]{4}{*}{ Flat $\mathrm{Cr}$. } & Dissolved & NA & NA & NA & 0.081 & NA & 0.0016 \\
\hline & Colloid & NA & NA & NA & NA & NA & NA \\
\hline & Dissolved + Colloid & $\mathrm{NC}$ & $\mathrm{NC}$ & $\mathrm{NC}$ & $\mathrm{NC}$ & $\mathrm{NC}$ & $\mathrm{NC}$ \\
\hline & Whole Water, TR & NA & NA & NA & 0.30 & NA & 0.0063 \\
\hline \multirow[t]{4}{*}{ Spring Cr-Weir } & Dissolved & NA & NA & NA & 210 & NA & 11 \\
\hline & Colloid & NA & NA & NA & 1.4 & NA & 0.63 \\
\hline & Dissolved + Colloid & $\mathrm{NC}$ & $\mathrm{NC}$ & $\mathrm{NC}$ & 210 & $\mathrm{NC}$ & 12 \\
\hline & Whole Water, TR & NA & NA & NA & 200 & NA & 12 \\
\hline \multirow[t]{4}{*}{$\overline{\text { Spring Cr-Road }}$} & Dissolved & NA & NA & NA & NA & 1,100 & NA \\
\hline & Colloid & NA & NA & NA & NA & 6.7 & NA \\
\hline & Dissolved + Colloid & $\mathrm{NC}$ & $\mathrm{NC}$ & $\mathrm{NC}$ & $\mathrm{NC}$ & 1,100 & $\mathrm{NC}$ \\
\hline & Whole Water, TR & NA & NA & NA & NA & 1,100 & NA \\
\hline \multirow{4}{*}{$\begin{array}{l}\text { Whiskeytown } \\
\text { Lake at SCPP }\end{array}$} & Dissolved & NA & NA & NA & 6.2 & NA & 2.7 \\
\hline & Colloid & NA & NA & NA & NA & NA & NA \\
\hline & Dissolved + Colloid & $\mathrm{NC}$ & $\mathrm{NC}$ & $\mathrm{NC}$ & $\mathrm{NC}$ & $\mathrm{NC}$ & $\mathrm{NC}$ \\
\hline & Whole Water, TR & NA & NA & NA & 11 & NA & 11 \\
\hline \multirow[t]{4}{*}{ Spring Cr. arm } & Dissolved & 10 & 2.9 & 7.8 & 91 & $\mathrm{NA}$ & 3.6 \\
\hline & Colloid & 0.77 & NA & 21 & 430 & NA & 16 \\
\hline & Dissolved + Colloid & 10 & $\mathrm{NC}$ & 28 & 520 & $\mathrm{NC}$ & 20 \\
\hline & Whole Water, TR & 5.6 & 8.9 & 40 & 480 & NA & 22 \\
\hline
\end{tabular}


Table A1-3. Copper loads derived from concentrations in dissolved, colloid, and whole water samples_-Continued

\begin{tabular}{|c|c|c|c|c|c|c|c|}
\hline \multirow[b]{2}{*}{ Site } & & \multicolumn{6}{|c|}{ Sampling Periods } \\
\hline & & $\begin{array}{l}\text { July } \\
1996\end{array}$ & $\begin{array}{l}\text { Sept. } \\
1996\end{array}$ & $\begin{array}{l}\text { Nov. } \\
1996\end{array}$ & $\begin{array}{l}\text { Dec. } \\
1996\end{array}$ & $\begin{array}{l}\text { Jan. } \\
1997\end{array}$ & $\begin{array}{c}\text { May-June } \\
1997\end{array}$ \\
\hline \multirow[t]{4}{*}{ Colusa Basin Drain } & Dissolved & NA & NA & NA & NA & NA & 1.6 \\
\hline & Colloid & NA & NA & NA & NA & NA & 17 \\
\hline & Dissolved + Colloid & $\mathrm{NC}$ & $\mathrm{NC}$ & $\mathrm{NC}$ & $\mathrm{NC}$ & $\mathrm{NC}$ & 18 \\
\hline & Whole Water, TR & NA & NA & NA & NA & NA & 15 \\
\hline \multirow[t]{4}{*}{ Yolo Bypass } & Dissolved & NA & NA & NA & NA & 360 & NA \\
\hline & Colloid & NA & $\mathrm{NA}$ & NA & NA & 7,300 & NA \\
\hline & Dissolved + Colloid & $\mathrm{NC}$ & $\mathrm{NC}$ & $\mathrm{NC}$ & $\mathrm{NC}$ & 7,700 & $\mathrm{NC}$ \\
\hline & Whole Water, TR & NA & NA & NA & NA & 6,600 & NA \\
\hline Freeport + Yolo & Dissolved & 39 & 15 & 12 & 140 & 640 & 16 \\
\hline \multirow[t]{3}{*}{ Bypass } & Colloid & 290 & 220 & 26 & 740 & 11,000 & 91 \\
\hline & Dissolved + Colloid & 330 & 240 & 38 & 880 & 12,000 & 110 \\
\hline & Whole Water, TR & 130 & 88 & 68 & 930 & 9,800 & 91 \\
\hline
\end{tabular}

${ }^{1}$ Samples collected at Tower Bridge in January 1997. 
Table A1-4. Iron loads derived from concentrations in dissolved, colloid, and whole water samples

[Loads in kilograms per day; Br., Bridge; Cr., Creek; NA, not analyzed; NC, not calculated; R., River; Sac., Sacramento; SCPP, Spring Creek Power Plant; TR, total recoverable analysis. $\leq$, load is less than or equal to value shown because of concentration less than detection limit; $\geq$, load is greater than or equal to value shown because of incomplete digestion of colloid sample]

\begin{tabular}{|c|c|c|c|c|c|c|c|}
\hline \multirow[b]{2}{*}{ Site } & & \multicolumn{6}{|c|}{ Sampling Periods } \\
\hline & & $\begin{array}{l}\text { July } \\
1996\end{array}$ & $\begin{array}{l}\text { Sept. } \\
1996\end{array}$ & $\begin{array}{l}\text { Nov. } \\
1996\end{array}$ & $\begin{array}{l}\text { Dec. } \\
1996\end{array}$ & $\begin{array}{l}\text { Jan. } \\
1997\end{array}$ & $\begin{array}{c}\text { May-June } \\
1997\end{array}$ \\
\hline \multirow[t]{4}{*}{ Sac R.-Shasta } & Dissolved & 270 & 93 & 21 & 220 & NA & 41 \\
\hline & Colloid & 4,900 & NA & 490 & $\geq 6,300$ & NA & 9,100 \\
\hline & Dissolved + Colloid & 5,200 & $\mathrm{NC}$ & 510 & $\geq 6,500$ & $\mathrm{NC}$ & 9,200 \\
\hline & Whole Water, TR & 4,100 & 930 & 490 & 6,400 & NA & 5,500 \\
\hline \multirow[t]{4}{*}{ Sac R.-Keswick } & Dissolved & 77 & 45 & 27 & 230 & 550 & 70 \\
\hline & Colloid & 4,600 & NA & 3,600 & 13,000 & 110,000 & 16,000 \\
\hline & Dissolved + Colloid & 4,700 & $\mathrm{NC}$ & 3,600 & 14,000 & 110,000 & 16,000 \\
\hline & Whole Water, TR & 4,200 & 1,200 & 3,200 & 14,000 & 84,000 & 9,400 \\
\hline \multirow[t]{4}{*}{ Sac R.-Bend Br. } & Dissolved & 110 & 33 & 55 & 280 & 1,100 & $\leq 25$ \\
\hline & Colloid & 7,200 & 3,300 & 10,000 & 200,000 & $1,800,000$ & 17,000 \\
\hline & Dissolved + Colloid & 7,300 & 3,300 & 10,000 & 200,000 & $1,800,000$ & $\leq 17,000$ \\
\hline & Whole Water, TR & 6,600 & 3,100 & 12,000 & 220,000 & $1,600,000$ & 9,900 \\
\hline \multirow[t]{4}{*}{ Sac R.-Colusa } & Dissolved & NA & 61 & 36 & 180 & 720 & 22 \\
\hline & Colloid & 76,000 & 13,000 & 19,000 & 590,000 & $3,200,000$ & 35,000 \\
\hline & Dissolved + Colloid & NA & 13,000 & 19,000 & 590,000 & $3,200,000$ & 35,000 \\
\hline & Whole Water, TR & 62,000 & 13,000 & 12,000 & 320,000 & $2,900,000$ & 24,000 \\
\hline \multirow[t]{4}{*}{ Sac R.-Verona } & Dissolved & 110 & 60 & NA & 610 & NA & 78 \\
\hline & Colloid & 47,000 & 58,000 & 34,000 & 480,000 & NA & 57,000 \\
\hline & Dissolved + Colloid & 47,000 & 58,000 & NA & 480,000 & $\mathrm{NC}$ & 57,000 \\
\hline & Whole Water, TR & 42,000 & 58,000 & 27,000 & 280,000 & NA & 37,000 \\
\hline \multirow[t]{4}{*}{ Sac R.-Freeport } & Dissolved & 220 & 150 & 32 & 690 & ${ }^{1} 1,600$ & 75 \\
\hline & Colloid & $\geq 72,000$ & $\geq 43,000$ & 12,000 & 450,000 & ${ }^{1} 2,300,000$ & 44,000 \\
\hline & Dissolved + Colloid & $\geq 73,000$ & $\geq 44,000$ & 12,000 & 450,000 & ${ }^{1} 2,300,000$ & 44,000 \\
\hline & Whole Water, TR & 42,000 & 22,000 & 13,000 & 410,000 & ${ }^{1} 1,900,000$ & 28,000 \\
\hline \multirow[t]{4}{*}{ Flat Cr. } & Dissolved & NA & NA & NA & 0.10 & NA & 0.30 \\
\hline & Colloid & NA & NA & NA & NA & NA & NA \\
\hline & Dissolved + Colloid & $\mathrm{NC}$ & $\mathrm{NC}$ & $\mathrm{NC}$ & $\mathrm{NC}$ & $\mathrm{NC}$ & $\mathrm{NC}$ \\
\hline & Whole Water, TR & NA & NA & NA & 6.2 & NA & 1.2 \\
\hline \multirow[t]{4}{*}{ Spring Cr.-Weir } & Dissolved & NA & NA & NA & 480 & NA & 14 \\
\hline & Colloid & NA & NA & NA & 340 & NA & 1,100 \\
\hline & Dissolved + Colloid & $\mathrm{NC}$ & $\mathrm{NC}$ & $\mathrm{NC}$ & 820 & $\mathrm{NC}$ & 1,100 \\
\hline & Whole Water, TR & NA & NA & NA & 690 & NA & 45 \\
\hline \multirow[t]{4}{*}{ Spring Cr.-Road } & Dissolved & NA & NA & NA & NA & 24,000 & NA \\
\hline & Colloid & NA & NA & NA & NA & 5,200 & NA \\
\hline & Dissolved + Colloid & $\mathrm{NC}$ & $\mathrm{NC}$ & $\mathrm{NC}$ & $\mathrm{NC}$ & 29,000 & $\mathrm{NC}$ \\
\hline & Whole Water, TR & NA & NA & NA & NA & 27,000 & NA \\
\hline \multirow{4}{*}{$\begin{array}{l}\text { Whiskeytown } \\
\text { Lake at SCPP }\end{array}$} & Dissolved & NA & NA & NA & 21 & NA & 19 \\
\hline & Colloid & NA & NA & NA & NA & NA & NA \\
\hline & Dissolved + Colloid & $\mathrm{NC}$ & $\mathrm{NC}$ & $\mathrm{NC}$ & $\mathrm{NC}$ & $\mathrm{NC}$ & $\mathrm{NC}$ \\
\hline & Whole Water, TR & NA & NA & NA & 380 & NA & 3,700 \\
\hline \multirow[t]{4}{*}{ Spring Cr. arm } & Dissolved & 10 & 19 & 13 & 71 & NA & 31 \\
\hline & Colloid & 140 & NA & 820 & 3,300 & NA & 6,600 \\
\hline & Dissolved + Colloid & 150 & $\mathrm{NC}$ & 830 & 3,300 & $\mathrm{NC}$ & 6,700 \\
\hline & Whole Water, TR & $\leq 200$ & $\leq 280$ & 760 & 2,000 & NA & 3,700 \\
\hline
\end{tabular}


Table A1-4. Iron loads derived from concentrations in dissolved, colloid, and whole water samples-Continued

\begin{tabular}{|c|c|c|c|c|c|c|c|}
\hline \multirow[b]{2}{*}{ Site } & & \multicolumn{6}{|c|}{ Sampling Periods } \\
\hline & & $\begin{array}{l}\text { July } \\
1996\end{array}$ & $\begin{array}{l}\text { Sept. } \\
1996\end{array}$ & $\begin{array}{l}\text { Nov. } \\
1996\end{array}$ & $\begin{array}{l}\text { Dec. } \\
1996\end{array}$ & $\begin{array}{l}\text { Jan. } \\
1997\end{array}$ & $\begin{array}{c}\text { May-June } \\
1997\end{array}$ \\
\hline \multirow[t]{4}{*}{ Colusa Basin Drain } & Dissolved & NA & NA & NA & NA & NA & 3.9 \\
\hline & Colloid & NA & NA & NA & NA & NA & 14,000 \\
\hline & Dissolved + Colloid & $\mathrm{NC}$ & $\mathrm{NC}$ & $\mathrm{NC}$ & $\mathrm{NC}$ & $\mathrm{NC}$ & 14,000 \\
\hline & Whole Water, TR & NA & NA & NA & NA & NA & 8,300 \\
\hline \multirow[t]{4}{*}{ Yolo Bypass } & Dissolved & NA & NA & NA & NA & 2,400 & NA \\
\hline & Colloid & NA & NA & NA & NA & $4,100,000$ & NA \\
\hline & Dissolved + Colloid & $\mathrm{NC}$ & $\mathrm{NC}$ & $\mathrm{NC}$ & $\mathrm{NC}$ & $4,100,000$ & $\mathrm{NC}$ \\
\hline & Whole Water, TR & NA & NA & NA & NA & $4,200,000$ & NA \\
\hline Freeport + Yolo & Dissolved & 220 & 150 & 32 & 690 & 4,000 & 75 \\
\hline \multirow[t]{3}{*}{ Bypass } & Colloid & 72,000 & 43,000 & 12,000 & 450,000 & $6,400,000$ & 44,000 \\
\hline & Dissolved + Colloid & 72,000 & 43,000 & 12,000 & 451,000 & $6,400,000$ & 44,000 \\
\hline & Whole Water, TR & 42,000 & 22,000 & 13,000 & 410,000 & $6,100,000$ & 28,000 \\
\hline
\end{tabular}

${ }^{1}$ Samples collected at Tower Bridge in January 1997. 
Table A1-5. Lead loads derived from concentrations in dissolved, colloid, and whole water samples

[Loads in kilograms per day; Br., Bridge; Cr., Creek; NA, not analyzed; NC, not calculated; R., River; Sac., Sacramento; SCPP, Spring Creek Power Plant; TR, total recoverable analysis. $\leq$, load is less than or equal to value shown because of concentration less than detection limit; $\geq$, load is greater than or equal to value shown because of incomplete digestion of colloid sample]

\begin{tabular}{|c|c|c|c|c|c|c|c|}
\hline \multirow[b]{2}{*}{ Site } & & \multicolumn{6}{|c|}{ Sampling Periods } \\
\hline & & $\begin{array}{l}\text { July } \\
1996\end{array}$ & $\begin{array}{l}\text { Sept. } \\
1996\end{array}$ & $\begin{array}{l}\text { Nov. } \\
1996\end{array}$ & $\begin{array}{l}\text { Dec. } \\
1996\end{array}$ & $\begin{array}{l}\text { Jan. } \\
1997\end{array}$ & $\begin{array}{c}\text { May-June } \\
1997\end{array}$ \\
\hline \multirow[t]{4}{*}{ Sac R.-Shasta } & Dissolved & $\leq 0.13$ & 0.10 & $\leq 0.10$ & 0.42 & NA & $\leq 0.10$ \\
\hline & Colloid & 1.1 & NA & 0.21 & $\geq 4.2$ & NA & 1.9 \\
\hline & Dissolved + Colloid & $\leq 1.2$ & $\mathrm{NC}$ & $\leq 0.30$ & $\geq 4.6$ & $\mathrm{NC}$ & $\leq 2.0$ \\
\hline & Whole Water, TR & 1.7 & 0.56 & 0.27 & 9.0 & NA & 1.8 \\
\hline \multirow[t]{4}{*}{ Sac R.-Keswick } & Dissolved & 0.29 & 0.21 & $\leq 0.11$ & 3.0 & 0.52 & $\leq 0.15$ \\
\hline & Colloid & 1.4 & NA & 3.7 & 13 & 51 & 2.9 \\
\hline & Dissolved + Colloid & 1.7 & $\mathrm{NC}$ & $\leq 3.8$ & 16 & 52 & $\leq 3.0$ \\
\hline & Whole Water, TR & 2.8 & 1.0 & 3.8 & 25 & 55 & 2.6 \\
\hline \multirow[t]{4}{*}{ Sac R.-Bend Br. } & Dissolved & 0.22 & 0.08 & 0.22 & 0.63 & 0.80 & $\leq 0.15$ \\
\hline & Colloid & 2.5 & 1.4 & 6.7 & 67 & 600 & 4.6 \\
\hline & Dissolved + Colloid & 2.7 & 1.5 & 6.9 & 67 & 600 & $\leq 4.7$ \\
\hline & Whole Water, TR & 3.5 & 1.7 & 7.8 & 98 & 500 & 4.0 \\
\hline \multirow[t]{4}{*}{ Sac R.-Colusa } & Dissolved & NA & 0.15 & 0.17 & 0.53 & 0.72 & 0.11 \\
\hline & Colloid & 24 & 6.9 & 11 & 170 & 930 & 11 \\
\hline & Dissolved + Colloid & $\mathrm{NC}$ & 7.1 & 11 & 170 & 930 & 11 \\
\hline & Whole Water, TR & 19 & 4.0 & 3.5 & 260 & 950 & 7.7 \\
\hline \multirow[t]{4}{*}{ Sac R. -Verona } & Dissolved & 0.50 & $\leq 0.15$ & NA & 1.1 & NA & 0.15 \\
\hline & Colloid & 21 & 19 & 16 & 160 & NA & 18 \\
\hline & Dissolved + Colloid & 21 & 19 & NA & 160 & $\mathrm{NC}$ & 18 \\
\hline & Whole Water, TR & 16 & 15 & 9.3 & 200 & NA & 13 \\
\hline \multirow[t]{4}{*}{ Sac R.-Freeport } & Dissolved & 1.1 & 0.30 & 0.24 & $\leq 1.1$ & ${ }^{1} 1.5$ & 0.21 \\
\hline & Colloid & $\geq 29$ & $\geq 22$ & 4.8 & 160 & ${ }^{1} 1,100$ & 15 \\
\hline & Dissolved + Colloid & $\geq 30$ & $\geq 22$ & 5.1 & 160 & ${ }^{1} 1,100$ & 16 \\
\hline & Whole Water, TR & 18 & 9.1 & 4.4 & 200 & ${ }^{1} 1,000$ & 12 \\
\hline \multirow[t]{4}{*}{ Flat Cr. } & Dissolved & NA & NA & NA & $\leq 0.00033$ & NA & $\leq 0.000010$ \\
\hline & Colloid & NA & NA & NA & NA & NA & NA \\
\hline & Dissolved + Colloid & $\mathrm{NC}$ & $\mathrm{NC}$ & $\mathrm{NC}$ & $\mathrm{NC}$ & $\mathrm{NC}$ & $\mathrm{NC}$ \\
\hline & Whole Water, TR & NA & NA & NA & 0.0052 & NA & 0.000093 \\
\hline \multirow[t]{4}{*}{ Spring Cr.-Weir } & Dissolved & NA & NA & NA & 0.54 & NA & 0.074 \\
\hline & Colloid & NA & NA & NA & 0.23 & NA & 0.21 \\
\hline & Dissolved + Colloid & $\mathrm{NC}$ & $\mathrm{NC}$ & $\mathrm{NC}$ & 0.77 & $\mathrm{NC}$ & 0.29 \\
\hline & Whole Water, TR & NA & NA & NA & 0.67 & NA & 0.092 \\
\hline \multirow[t]{4}{*}{ Spring Cr.-Road } & Dissolved & NA & NA & NA & NA & 6.8 & NA \\
\hline & Colloid & NA & NA & NA & NA & 1.4 & NA \\
\hline & Dissolved + Colloid & $\mathrm{NC}$ & $\mathrm{NC}$ & $\mathrm{NC}$ & $\mathrm{NC}$ & 8.2 & $\mathrm{NC}$ \\
\hline & Whole Water, TR & NA & NA & NA & NA & 8.3 & NA \\
\hline \multirow{4}{*}{$\begin{array}{l}\text { Whiskeytown } \\
\text { Lake at SCPP }\end{array}$} & Dissolved & NA & NA & NA & $\leq 0.086$ & NA & $\leq 0.020$ \\
\hline & Colloid & NA & NA & NA & NA & NA & NA \\
\hline & Dissolved + Colloid & $\mathrm{NC}$ & $\mathrm{NC}$ & $\mathrm{NC}$ & $\mathrm{NC}$ & $\mathrm{NC}$ & $\mathrm{NC}$ \\
\hline & Whole Water, TR & NA & NA & NA & 0.58 & NA & 0.77 \\
\hline \multirow[t]{4}{*}{ Spring Cr. arm } & Dissolved & $\leq 0.052$ & $\leq 0.086$ & $\leq 0.025$ & 0.084 & NA & 0.047 \\
\hline & Colloid & 0.040 & NA & 0.40 & 2.8 & NA & 0.69 \\
\hline & Dissolved + Colloid & $\leq 0.093$ & $\mathrm{NC}$ & $\leq 0.43$ & 2.9 & $\mathrm{NC}$ & 0.74 \\
\hline & Whole Water, TR & 0.20 & 0.22 & 0.37 & 2.6 & NA & 0.55 \\
\hline
\end{tabular}


Table A1-5. Lead loads derived from concentrations in dissolved, colloid, and whole water samples-Continued

\begin{tabular}{|c|c|c|c|c|c|c|c|}
\hline \multirow[b]{2}{*}{ Site } & & \multicolumn{6}{|c|}{ Sampling Periods } \\
\hline & & $\begin{array}{l}\text { July } \\
1996\end{array}$ & $\begin{array}{l}\text { Sept. } \\
1996\end{array}$ & $\begin{array}{l}\text { Nov. } \\
1996\end{array}$ & $\begin{array}{l}\text { Dec. } \\
1996\end{array}$ & $\begin{array}{l}\text { Jan. } \\
1997\end{array}$ & $\begin{array}{c}\text { May-June } \\
1997\end{array}$ \\
\hline \multirow[t]{4}{*}{ Colusa Basin Drain } & Dissolved & NA & NA & NA & NA & NA & 0.012 \\
\hline & Colloid & $\mathrm{NA}$ & NA & NA & NA & NA & 3.5 \\
\hline & Dissolved + Colloid & $\mathrm{NC}$ & $\mathrm{NC}$ & $\mathrm{NC}$ & $\mathrm{NC}$ & $\mathrm{NC}$ & 3.6 \\
\hline & Whole Water, TR & NA & NA & NA & NA & NA & 2.6 \\
\hline \multirow[t]{4}{*}{ Yolo Bypass } & Dissolved & NA & NA & NA & NA & 4.9 & NA \\
\hline & Colloid & NA & $\mathrm{NA}$ & NA & NA & 1,200 & NA \\
\hline & Dissolved + Colloid & $\mathrm{NC}$ & $\mathrm{NC}$ & $\mathrm{NC}$ & $\mathrm{NC}$ & 1,200 & $\mathrm{NC}$ \\
\hline & Whole Water, TR & NA & NA & NA & NA & 1,400 & NA \\
\hline Freeport + Yolo & Dissolved & 1.1 & 0.30 & 0.28 & 1.1 & 6.4 & 0.21 \\
\hline \multirow[t]{3}{*}{ Bypass } & Colloid & 29 & 22 & 4.8 & 160 & 2,300 & 15 \\
\hline & Dissolved + Colloid & 30 & 22 & 5.1 & 160 & 2,300 & 15 \\
\hline & Whole Water, TR & 18 & 9.1 & 4.4 & 200 & 2,400 & 12 \\
\hline
\end{tabular}

${ }^{1}$ Samples collected at Tower Bridge in January 1997. 
Table A1-6. Mercury loads derived from concentrations in dissolved, colloid, and whole water samples

[Loads in grams per day; Br., Bridge; Cr., Creek; NA, not analyzed; NC, not calculated; R., River; Sac., Sacramento; SCPP, Spring Creek Power Plant; TR, total recoverable analysis. $\leq$, load is less than or equal to value shown because of concentration less than detection limit; $\geq$, load is greater than or equal to value shown because of incomplete digestion of colloid sample]

\begin{tabular}{|c|c|c|c|c|c|c|c|}
\hline \multirow[b]{2}{*}{ Site } & & \multicolumn{6}{|c|}{ Sampling Periods } \\
\hline & & $\begin{array}{l}\text { July } \\
1996\end{array}$ & $\begin{array}{l}\text { Sept. } \\
1996\end{array}$ & $\begin{array}{l}\text { Nov. } \\
1996\end{array}$ & $\begin{array}{l}\text { Dec. } \\
1996\end{array}$ & $\begin{array}{l}\text { Jan. } \\
1997\end{array}$ & $\begin{array}{c}\text { May-June } \\
1997\end{array}$ \\
\hline \multirow[t]{4}{*}{ Sac R.-Shasta } & Dissolved & 27 & $\leq 9.7$ & 6.3 & 85 & NA & 19 \\
\hline & Colloid & 16 & NA & 4.1 & $\geq 67$ & NA & 24 \\
\hline & Dissolved + Colloid & 43 & $\mathrm{NC}$ & 10 & $\geq 150$ & $\mathrm{NC}$ & 43 \\
\hline & Whole Water, TR & 24 & $\leq 6.8$ & 9.5 & 67.0 & NA & 38 \\
\hline \multirow[t]{4}{*}{ Sac R.-Keswick } & Dissolved & 33 & $\leq 8.1$ & 14 & 75 & $\leq 32$ & 18 \\
\hline & Colloid & 26 & NA & 21 & 160 & 810 & 53 \\
\hline & Dissolved + Colloid & 59 & $\mathrm{NC}$ & 35 & 230 & $\leq 840$ & 71 \\
\hline & Whole Water, TR & 41 & 18 & 30 & 140 & 810 & 88 \\
\hline \multirow[t]{4}{*}{ Sac R.-Bend Br. } & Dissolved & 33 & $\leq 9.3$ & 15 & 97 & $\leq 120$ & 26 \\
\hline & Colloid & 35 & 15 & 62 & 610 & 6,100 & 48 \\
\hline & Dissolved + Colloid & 68 & $\leq 24$ & 78 & 710 & $\leq 6,200$ & 74 \\
\hline & Whole Water, TR & 59 & 29 & 63 & 730 & 2,100 & 71 \\
\hline \multirow[t]{4}{*}{ Sac R.-Colusa } & Dissolved & NA & $\leq 9.0$ & 11 & 57 & 140 & 11 \\
\hline & Colloid & 290 & 110 & 170 & 1,800 & 11,000 & 120 \\
\hline & Dissolved + Colloid & $\mathrm{NC}$ & 110 & 180 & 1,800 & 11,000 & 130 \\
\hline & Whole Water, TR & 170 & 38 & 34 & 840 & 9,900 & 91 \\
\hline \multirow[t]{4}{*}{ Sac R.-Verona } & Dissolved & 39 & 19.0 & NA & 130 & NA & 24 \\
\hline & Colloid & 260 & 570 & 120 & 1,700 & NA & 210 \\
\hline & Dissolved + Colloid & 300 & 590 & $\mathrm{NC}$ & 1,800 & $\mathrm{NC}$ & 230 \\
\hline & Whole Water, TR & 180 & 180 & 44 & 1,000 & NA & 130 \\
\hline \multirow[t]{4}{*}{ Sac R.-Freeport } & Dissolved & 41 & $\leq 13$ & 22 & 160 & ${ }^{1} 160$ & 32 \\
\hline & Colloid & NA & NA & 54 & 1,700 & ${ }^{1} 4,600$ & 130 \\
\hline & Dissolved + Colloid & $\mathrm{NC}$ & $\mathrm{NC}$ & 76 & 1,800 & ${ }^{1} 4,800$ & 160 \\
\hline & Whole Water, TR & 210 & 76 & 49 & 1,800 & ${ }^{1} 6,700$ & 160 \\
\hline \multirow[t]{4}{*}{ Flat Cr. } & Dissolved & NA & NA & NA & 0.029 & NA & 0.0036 \\
\hline & Colloid & NA & NA & NA & NA & NA & NA \\
\hline & Dissolved + Colloid & $\mathrm{NC}$ & $\mathrm{NC}$ & $\mathrm{NC}$ & $\mathrm{NC}$ & $\mathrm{NC}$ & $\mathrm{NC}$ \\
\hline & Whole Water, TR & NA & NA & NA & 0.090 & NA & 0.0069 \\
\hline \multirow[t]{4}{*}{ Spring Cr.-Weir } & Dissolved & NA & NA & NA & 0.69 & NA & 0.045 \\
\hline & Colloid & NA & NA & NA & 8.0 & NA & 0.60 \\
\hline & Dissolved + Colloid & $\mathrm{NC}$ & $\mathrm{NC}$ & $\mathrm{NC}$ & 8.7 & $\mathrm{NC}$ & 0.64 \\
\hline & Whole Water, TR & NA & NA & NA & 6.6 & NA & 0.22 \\
\hline \multirow[t]{4}{*}{ Spring Cr.-Road } & Dissolved & NA & NA & NA & NA & 1.9 & NA \\
\hline & Colloid & NA & NA & NA & NA & 110 & NA \\
\hline & Dissolved + Colloid & $\mathrm{NC}$ & $\mathrm{NC}$ & $\mathrm{NC}$ & $\mathrm{NC}$ & 110 & $\mathrm{NC}$ \\
\hline & Whole Water, TR & NA & NA & NA & NA & 83 & NA \\
\hline \multirow{4}{*}{$\begin{array}{l}\text { Whiskeytown } \\
\text { Lake at SCPP }\end{array}$} & Dissolved & NA & NA & NA & 8.7 & NA & 4.3 \\
\hline & Colloid & NA & NA & NA & NA & NA & NA \\
\hline & Dissolved + Colloid & $\mathrm{NC}$ & $\mathrm{NC}$ & $\mathrm{NC}$ & $\mathrm{NC}$ & $\mathrm{NC}$ & $\mathrm{NC}$ \\
\hline & Whole Water, TR & NA & NA & NA & 9.1 & NA & 19 \\
\hline \multirow[t]{4}{*}{ Spring Cr. arm } & Dissolved & 5.7 & $\leq 3.1$ & 2.8 & $\leq 4.6$ & NA & 16 \\
\hline & Colloid & 1.7 & NA & 4.2 & 44 & NA & 19 \\
\hline & Dissolved + Colloid & 7.4 & $\mathrm{NC}$ & 7.0 & $\leq 49$ & $\mathrm{NC}$ & 34 \\
\hline & Whole Water, TR & 7.7 & 5.5 & 4.1 & 33 & NA & 27 \\
\hline
\end{tabular}


Table A1-6. Mercury loads derived from concentrations in dissolved, colloid, and whole water samples-Continued

\begin{tabular}{|c|c|c|c|c|c|c|c|}
\hline \multirow[b]{2}{*}{ Site } & & \multicolumn{6}{|c|}{ Sampling Periods } \\
\hline & & $\begin{array}{l}\text { July } \\
1996\end{array}$ & $\begin{array}{l}\text { Sept. } \\
1996\end{array}$ & $\begin{array}{l}\text { Nov. } \\
1996\end{array}$ & $\begin{array}{l}\text { Dec. } \\
1996\end{array}$ & $\begin{array}{l}\text { Jan. } \\
1997\end{array}$ & $\begin{array}{c}\text { May-June } \\
1997\end{array}$ \\
\hline \multirow[t]{4}{*}{ Colusa Basin Drain } & Dissolved & NA & NA & NA & NA & NA & 0.91 \\
\hline & Colloid & NA & NA & NA & NA & NA & 19 \\
\hline & Dissolved + Colloid & $\mathrm{NC}$ & $\mathrm{NC}$ & $\mathrm{NC}$ & $\mathrm{NC}$ & $\mathrm{NC}$ & 20 \\
\hline & Whole Water, TR & NA & NA & NA & NA & NA & 11 \\
\hline \multirow[t]{4}{*}{ Yolo Bypass } & Dissolved & NA & NA & NA & NA & 440 & NA \\
\hline & Colloid & NA & NA & NA & NA & 19,000 & NA \\
\hline & Dissolved + Colloid & $\mathrm{NC}$ & $\mathrm{NC}$ & $\mathrm{NC}$ & $\mathrm{NC}$ & 20,000 & $\mathrm{NC}$ \\
\hline & Whole Water, TR & NA & NA & NA & NA & 18,000 & NA \\
\hline \multirow{4}{*}{$\begin{array}{l}\text { Freeport + Yolo } \\
\text { Bypass }\end{array}$} & Dissolved & 41 & 13 & 22 & 160 & 600 & 32 \\
\hline & Colloid & NA & NA & 54 & 1,700 & 24,000 & 130 \\
\hline & Dissolved + Colloid & $\mathrm{NC}$ & $\mathrm{NC}$ & $\mathrm{NC}$ & 1,900 & 24,000 & 160 \\
\hline & Whole Water, TR & 210 & 76 & 49 & 1,800 & 25,000 & 160 \\
\hline
\end{tabular}

${ }^{1}$ Samples collected at Tower Bridge in January 1997. 
Table A1-7. Zinc loads derived from concentrations in dissolved, colloid, and whole water samples

[Loads in kilograms per day; Br., Bridge; Cr., Creek; NA, not analyzed; NC, not calculated; R., River; Sac., Sacramento; SCPP, Spring Creek Power Plant; TR, total recoverable analysis. $\geq$, load is greater than or equal to value shown because of incomplete digestion of colloid sample]

\begin{tabular}{|c|c|c|c|c|c|c|c|}
\hline \multirow[b]{2}{*}{ Site } & & \multicolumn{6}{|c|}{ Sampling Periods } \\
\hline & & $\begin{array}{l}\text { July } \\
1996\end{array}$ & $\begin{array}{l}\text { Sept. } \\
1996\end{array}$ & $\begin{array}{l}\text { Nov. } \\
1996\end{array}$ & $\begin{array}{l}\text { Dec. } \\
1996\end{array}$ & $\begin{array}{l}\text { Jan. } \\
1997\end{array}$ & $\begin{array}{c}\text { May-June } \\
1997\end{array}$ \\
\hline \multirow[t]{4}{*}{ Sac R.-Shasta } & Dissolved & 67 & 61 & 12 & 260 & NA & 11 \\
\hline & Colloid & 37 & $\mathrm{NA}$ & 7.0 & $\geq 110$ & NA & 41 \\
\hline & Dissolved + Colloid & 100 & $\mathrm{NC}$ & 19 & $\geq 370$ & $\mathrm{NC}$ & 53 \\
\hline & Whole Water, TR & 110 & 94 & 28 & 520 & NA & 47 \\
\hline \multirow[t]{4}{*}{ Sac R.-Keswick } & Dissolved & 74 & 57 & 37 & 420 & 830 & 40 \\
\hline & Colloid & 39 & $\mathrm{NA}$ & 40 & 280 & 1,400 & 83 \\
\hline & Dissolved + Colloid & 110 & $\mathrm{NC}$ & 77 & 700 & 2,300 & 120 \\
\hline & Whole Water, TR & 120 & 87 & 110 & 950 & 2,700 & 100 \\
\hline \multirow[t]{4}{*}{ Sac R.-Bend Br. } & Dissolved & 45 & 49 & 36 & 84 & 88 & 27 \\
\hline & Colloid & 61 & 11 & 84 & 1,300 & 6,300 & 93 \\
\hline & Dissolved + Colloid & 110 & 60 & 120 & 1,400 & 6,400 & 120 \\
\hline & Whole Water, TR & 130 & 120 & 180 & 1,300 & 5,300 & 100 \\
\hline \multirow[t]{4}{*}{ Sac R.-Colusa } & Dissolved & NA & 8.2 & 6.0 & 47 & 23 & 15 \\
\hline & Colloid & 350 & 76 & 120 & 2,400 & 8,400 & 160 \\
\hline & Dissolved + Colloid & $\mathrm{NC}$ & 84 & 130 & 2,500 & 8,400 & 170 \\
\hline & Whole Water, TR & 280 & 77 & 64 & 1,400 & 7,300 & 110 \\
\hline \multirow{4}{*}{ Sac R.-Verona } & Dissolved & 8.1 & 12 & NA & 66 & NA & 11 \\
\hline & Colloid & 240 & 210 & 150 & 1,600 & NA & 200 \\
\hline & Dissolved + Colloid & 250 & 220 & NA & 1,600 & $\mathrm{NC}$ & 210 \\
\hline & Whole Water, TR & 180 & 200 & 110 & 1,100 & NA & 150 \\
\hline \multirow[t]{4}{*}{ Sac R.-Freeport } & Dissolved & 18 & 45 & 20 & 70 & ${ }^{1} 150$ & 11 \\
\hline & Colloid & $\geq 430$ & $\geq 540$ & 57 & 1,300 & ${ }^{1} 4,700$ & 150 \\
\hline & Dissolved + Colloid & $\geq 450$ & $\geq 590$ & 77 & 1,400 & ${ }^{1} 4,800$ & 170 \\
\hline & Whole Water, TR & 170 & 110 & 100 & 1,500 & ${ }^{1} 4,000$ & 110 \\
\hline \multirow[t]{4}{*}{ Flat Cr. } & Dissolved & NA & NA & NA & 0.34 & NA & 0.018 \\
\hline & Colloid & NA & NA & NA & NA & NA & NA \\
\hline & Dissolved + Colloid & $\mathrm{NC}$ & $\mathrm{NC}$ & $\mathrm{NC}$ & $\mathrm{NC}$ & $\mathrm{NC}$ & $\mathrm{NC}$ \\
\hline & Whole Water, TR & NA & NA & NA & 0.71 & NA & 0.019 \\
\hline \multirow[t]{4}{*}{ Spring Cr.-Weir } & Dissolved & NA & NA & NA & 270 & NA & 21 \\
\hline & Colloid & NA & NA & NA & 1.4 & NA & 0.21 \\
\hline & Dissolved + Colloid & $\mathrm{NC}$ & $\mathrm{NC}$ & $\mathrm{NC}$ & 270 & $\mathrm{NC}$ & 21 \\
\hline & Whole Water, TR & NA & NA & NA & 230 & NA & 22 \\
\hline \multirow[t]{4}{*}{ Spring Cr.-Road } & Dissolved & NA & NA & NA & NA & 2,600 & $\mathrm{NA}$ \\
\hline & Colloid & NA & NA & NA & NA & 3.5 & NA \\
\hline & Dissolved + Colloid & $\mathrm{NC}$ & $\mathrm{NC}$ & $\mathrm{NC}$ & $\mathrm{NC}$ & 2,600 & $\mathrm{NC}$ \\
\hline & Whole Water, TR & NA & NA & NA & NA & 2,800 & NA \\
\hline \multirow{4}{*}{$\begin{array}{l}\text { Whiskeytown } \\
\text { Lake at SCPP }\end{array}$} & Dissolved & NA & NA & NA & 8.9 & NA & 1.7 \\
\hline & Colloid & NA & NA & NA & NA & NA & NA \\
\hline & Dissolved + Colloid & $\mathrm{NC}$ & $\mathrm{NC}$ & $\mathrm{NC}$ & $\mathrm{NC}$ & $\mathrm{NC}$ & $\mathrm{NC}$ \\
\hline & Whole Water, TR & NA & NA & NA & 10.0 & NA & 7.1 \\
\hline \multirow[t]{4}{*}{ Spring Cr. arm } & Dissolved & 5.0 & 14 & 40 & 360 & NA & 14 \\
\hline & Colloid & 1.1 & NA & 22 & 220 & NA & 25 \\
\hline & Dissolved + Colloid & 6.2 & NA & 62 & 580 & $\mathrm{NC}$ & 39 \\
\hline & Whole Water, TR & 6.0 & 22 & 74 & 600 & NA & 32 \\
\hline
\end{tabular}


Table A1-7. Zinc loads derived from concentrations in dissolved, colloid, and whole water samples_Continued

\begin{tabular}{|c|c|c|c|c|c|c|c|}
\hline \multirow[b]{2}{*}{ Site } & & \multicolumn{6}{|c|}{ Sampling Periods } \\
\hline & & $\begin{array}{l}\text { July } \\
1996\end{array}$ & $\begin{array}{l}\text { Sept. } \\
1996\end{array}$ & $\begin{array}{l}\text { Nov. } \\
1996\end{array}$ & $\begin{array}{l}\text { Dec. } \\
1996\end{array}$ & $\begin{array}{l}\text { Jan. } \\
1997\end{array}$ & $\begin{array}{c}\text { May-June } \\
1997\end{array}$ \\
\hline \multirow[t]{4}{*}{ Colusa Basin Drain } & Dissolved & NA & NA & NA & NA & NA & 0.37 \\
\hline & Colloid & NA & NA & NA & NA & NA & 33 \\
\hline & Dissolved + Colloid & $\mathrm{NC}$ & $\mathrm{NC}$ & $\mathrm{NC}$ & $\mathrm{NC}$ & $\mathrm{NC}$ & 34 \\
\hline & Whole Water, TR & NA & NA & NA & NA & NA & 23 \\
\hline \multirow[t]{4}{*}{ Yolo Bypass } & Dissolved & NA & NA & NA & NA & 79 & NA \\
\hline & Colloid & NA & NA & NA & NA & 10,000 & NA \\
\hline & Dissolved + Colloid & $\mathrm{NC}$ & $\mathrm{NC}$ & $\mathrm{NC}$ & $\mathrm{NC}$ & 10,000 & $\mathrm{NC}$ \\
\hline & Whole Water, TR & NA & NA & NA & NA & 9,700 & NA \\
\hline \multirow[t]{4}{*}{ Freeport + Yolo Bypass } & Dissolved & 18 & 45 & 20 & 70 & 229 & 11 \\
\hline & Colloid & 430 & 540 & 57 & 1,300 & 14,700 & 150 \\
\hline & Dissolved + Colloid & 450 & 590 & 77 & 1,400 & 15,000 & 160 \\
\hline & Whole Water, TR & 170 & 110 & 100 & 1,500 & 13,700 & 110 \\
\hline
\end{tabular}

${ }^{1}$ Samples collected at Tower Bridge in January 1997. 



\section{Appendix 2. Tables of Data Comparing Metal Loads Relative to Loads at Freeport and in the Yolo Bypass}

Table A2-1. Aluminum loads divided by sum of loads at Freeport and in Yolo Bypass, derived from concentrations in dissolved, colloid, and whole water samples

Table A2-2. Cadmium loads divided by sum of loads at Freeport and in Yolo Bypass, derived from concentrations in dissolved, colloid, and whole water samples

Table A2-3. Copper loads divided by sum of loads at Freeport and in Yolo Bypass, derived from concentrations in dissolved, colloid, and whole water samples

Table A2-4. Iron loads divided by sum of loads at Freeport and in Yolo Bypass, derived from concentrations in dissolved, colloid, and whole water samples

Table A2-5. Lead loads divided by sum of loads at Freeport and in Yolo Bypass, derived from concentrations in dissolved, colloid, and whole water samples

Table A2-6. Mercury loads divided by sum of loads at Freeport and in Yolo Bypass, derived from concentrations in dissolved, colloid, and whole water samples

Table A2-7. Zinc loads divided by sum of loads at Freeport and in Yolo Bypass, derived from concentrations in dissolved, colloid, and whole water samples 
Table A2-1. Aluminum loads divided by sum of loads at Freeport and in Yolo Bypass, derived from concentrations in dissolved, colloid, and whole water samples

[Br., Bridge; Cr., Creek; NA, not analyzed; R., River; Sac., Sacramento; SCPP, Spring Creek Power Plant; TR, total recoverable analysis]

\begin{tabular}{|c|c|c|c|c|c|c|c|}
\hline \multirow{3}{*}{ Site } & & \multicolumn{6}{|c|}{ Sampling Periods } \\
\hline & & \multirow{2}{*}{$\begin{array}{l}\text { July } \\
1996\end{array}$} & \multirow{2}{*}{$\begin{array}{l}\text { Sept. } \\
1996\end{array}$} & \multirow{2}{*}{$\begin{array}{l}\text { Nov. } \\
1996\end{array}$} & \multirow{2}{*}{$\begin{array}{l}\text { Dec. } \\
1996\end{array}$} & \multirow{2}{*}{$\begin{array}{l}\text { Jan. } \\
1997\end{array}$} & \multirow{2}{*}{$\begin{array}{c}\text { May-June } \\
1997\end{array}$} \\
\hline & & & & & & & \\
\hline \multirow[t]{4}{*}{ Sac R.-Shasta } & Dissolved & 0.44 & 0.80 & 0.40 & 0.65 & NA & 0.43 \\
\hline & Colloid & NA & NA & 0.052 & 0.020 & NA & 0.24 \\
\hline & Dissolved + Colloid & 0.13 & NA & 0.053 & 0.020 & NA & 0.24 \\
\hline & Whole Water, TR & 0.13 & 0.06 & 0.055 & 0.020 & NA & 0.25 \\
\hline \multirow[t]{4}{*}{ Sac R.-Keswick } & Dissolved & 0.68 & 2.9 & 5.6 & 2.7 & 0.50 & 1.6 \\
\hline & Colloid & NA & NA & 0.28 & 0.033 & 0.010 & 0.35 \\
\hline & Dissolved + Colloid & 0.13 & NA & 0.29 & 0.036 & 0.010 & 0.35 \\
\hline & Whole Water, TR & 0.13 & 0.071 & 0.30 & 0.038 & 0.011 & 0.36 \\
\hline \multirow[t]{4}{*}{ Sac R.-Bend Br. } & Dissolved & 0.70 & 1.5 & 5.2 & 1.6 & 0.34 & 1.4 \\
\hline & Colloid & NA & NA & 0.93 & 0.51 & 0.23 & 0.37 \\
\hline & Dissolved + Colloid & 0.17 & 0.13 & 1.0 & 0.51 & 0.23 & 0.38 \\
\hline & Whole Water, TR & 0.18 & 0.14 & 1.0 & 0.51 & 0.22 & 0.38 \\
\hline \multirow[t]{4}{*}{ Sac R.-Colusa } & Dissolved & NA & 0.83 & 0.96 & 0.50 & 0.21 & 0.81 \\
\hline & Colloid & NA & NA & 1.5 & 0.76 & 0.44 & 0.79 \\
\hline & Dissolved + Colloid & NA & 0.54 & 1.5 & 0.76 & 0.44 & 0.79 \\
\hline & Whole Water, TR & 1.6 & 0.54 & 1.5 & 0.76 & 0.44 & 0.81 \\
\hline \multirow[t]{4}{*}{ Sac R.-Verona } & Dissolved & 1.1 & 1.0 & NA & 0.48 & NA & 0.70 \\
\hline & Colloid & NA & NA & 2.7 & 0.71 & NA & 1.2 \\
\hline & Dissolved + Colloid & 1.0 & 2.4 & NA & 0.71 & NA & 1.2 \\
\hline & Whole Water, TR & 1.0 & 2.4 & 2.8 & 0.70 & NA & 1.2 \\
\hline \multirow[t]{4}{*}{ Sac R.-Freeport } & Dissolved & 1.0 & 1.0 & 1.0 & 1.0 & ${ }^{1} 0.58$ & 1.0 \\
\hline & Colloid & NA & NA & 1.0 & 1.0 & ${ }^{1} 0.40$ & 1.0 \\
\hline & Dissolved + Colloid & 1.0 & 1.0 & 1.0 & 1.0 & ${ }^{1} 0.40$ & 1.0 \\
\hline & Whole Water, TR & 1.0 & 1.0 & 1.0 & 1.0 & ${ }^{1} 0.39$ & 1.0 \\
\hline \multirow[t]{4}{*}{ Flat Cr. } & Dissolved & NA & NA & NA & 0.0013 & NA & 0.000062 \\
\hline & Colloid & NA & NA & NA & NA & NA & NA \\
\hline & Dissolved + Colloid & NA & NA & NA & NA & NA & NA \\
\hline & Whole Water, TR & NA & NA & NA & 0.000024 & NA & 0.00000065 \\
\hline \multirow[t]{4}{*}{ Spring Cr.-Weir } & Dissolved & NA & NA & NA & 1.9 & NA & 1.5 \\
\hline & Colloid & NA & NA & NA & 0.00053 & NA & 0.0013 \\
\hline & Dissolved + Colloid & NA & NA & NA & 0.0027 & NA & 0.0029 \\
\hline & Whole Water, TR & NA & NA & NA & 0.0038 & NA & 0.0050 \\
\hline \multirow[t]{4}{*}{ Spring Cr.-Road } & Dissolved & NA & NA & NA & NA & 1.6 & NA \\
\hline & Colloid & NA & NA & NA & NA & 0.00022 & NA \\
\hline & Dissolved + Colloid & NA & NA & NA & NA & 0.00067 & NA \\
\hline & Whole Water, TR & NA & NA & NA & NA & 0.00093 & NA \\
\hline Whiskeytown & Dissolved & NA & NA & NA & 0.034 & NA & 0.25 \\
\hline \multirow[t]{3}{*}{ Lake at SCPP } & Colloid & NA & NA & NA & NA & NA & NA \\
\hline & Dissolved + Colloid & NA & NA & NA & NA & NA & NA \\
\hline & Whole Water, TR & NA & NA & NA & 0.00084 & NA & 0.11 \\
\hline Spring Cr. arm & Dissolved & 0.23 & 1.1 & 5.2 & 0.94 & NA & 1.3 \\
\hline & Colloid & NA & NA & 0.057 & 0.0084 & NA & 0.10 \\
\hline & Dissolved + Colloid & 0.0028 & NA & 0.066 & 0.0093 & NA & 0.10 \\
\hline & Whole Water, TR & 0.0028 & 0.0079 & 0.072 & 0.010 & NA & 0.11 \\
\hline Colusa Basin Drain & Dissolved & NA & NA & NA & NA & NA & 0.017 \\
\hline & Colloid & NA & NA & NA & NA & NA & 0.25 \\
\hline & Dissolved + Colloid & NA & NA & NA & NA & NA & 0.25 \\
\hline & Whole Water, TR & NA & NA & NA & NA & NA & 0.25 \\
\hline Yolo Bypass & Dissolved & NA & NA & NA & NA & 0.42 & NA \\
\hline & Colloid & NA & NA & NA & NA & 0.60 & NA \\
\hline & Dissolved + Colloid & NA & NA & NA & NA & 0.60 & NA \\
\hline & Whole Water, TR & NA & NA & NA & NA & 0.39 & NA \\
\hline
\end{tabular}

${ }^{1}$ Samples collected at Tower Bridge in January 1997. 
Table A2-2. Cadmium loads divided by sum of loads at Freeport and in Yolo Bypass, derived from concentrations in dissolved, colloid, and whole water samples

[Br., Bridge; Cr., Creek; NA, not analyzed; R., River; Sac., Sacramento; SCPP, Spring Creek Power Plant; TR, total recoverable analysis]

\begin{tabular}{|c|c|c|c|c|c|c|c|}
\hline \multirow{3}{*}{ Site } & & \multicolumn{6}{|c|}{ Sampling Periods } \\
\hline & & July & Sept. & Nov. & Dec. & Jan. & May-June \\
\hline & & 1996 & 1996 & 1996 & 1996 & 1997 & 1997 \\
\hline \multirow[t]{4}{*}{ Sac R.-Shasta } & Dissolved & 1.4 & 1.5 & 0.51 & 2.9 & NA & 0.37 \\
\hline & Colloid & NA & NA & 0.27 & 0.062 & NA & 0.18 \\
\hline & Dissolved + Colloid & 0.23 & NA & 0.37 & 0.48 & NA & 0.22 \\
\hline & Whole Water, TR & 0.48 & 0.66 & 0.27 & 0.54 & NA & 0.46 \\
\hline \multirow[t]{4}{*}{ Sac R.-Keswick } & Dissolved & 1.4 & 1.7 & 3.1 & 4.9 & 2.8 & 1.1 \\
\hline & Colloid & NA & NA & 1.0 & 0.19 & 0.10 & 0.34 \\
\hline & Dissolved + Colloid & 0.27 & NA & 1.9 & 0.87 & 0.22 & 0.53 \\
\hline & Whole Water, TR & 0.50 & 0.74 & 2.0 & 0.83 & 0.38 & 0.63 \\
\hline \multirow[t]{4}{*}{ Sac R.-Bend Br. } & Dissolved & 1.9 & 1.4 & 2.4 & 2.3 & 0.45 & 0.65 \\
\hline & Colloid & NA & NA & 1.7 & 0.87 & 0.36 & 0.35 \\
\hline & Dissolved + Colloid & 0.36 & 0.09 & 2.0 & 1.1 & 0.37 & 0.42 \\
\hline & Whole Water, TR & 0.60 & 0.70 & 2.0 & 0.92 & 0.45 & 1.02 \\
\hline \multirow[t]{4}{*}{ Sac R.-Colusa } & Dissolved & NA & 0.75 & 0.54 & 0.59 & 0.22 & 0.62 \\
\hline & Colloid & NA & NA & 3.9 & 1.5 & 0.45 & 0.92 \\
\hline & Dissolved + Colloid & NA & 0.19 & 2.5 & 1.4 & 0.45 & 0.84 \\
\hline & Whole Water, TR & 0.95 & 0.79 & 0.75 & 0.78 & 0.46 & 0.85 \\
\hline \multirow[t]{4}{*}{ Sac R.-Verona } & Dissolved & 0.48 & 1.0 & NA & 0.88 & NA & 0.81 \\
\hline & Colloid & NA & NA & 4.1 & 1.2 & NA & 1.1 \\
\hline & Dissolved + Colloid & 0.78 & 0.35 & NA & 1.1 & NA & 1.1 \\
\hline & Whole Water, TR & 1.1 & 1.5 & 1.4 & 0.61 & NA & 1.2 \\
\hline \multirow[t]{4}{*}{ Sac R.-Freeport } & Dissolved & 1.0 & 1.0 & 1.0 & 1.0 & ${ }^{1} 0.35$ & 1.0 \\
\hline & Colloid & NA & NA & 1.0 & 1.0 & ${ }^{1} 0.30$ & 1.0 \\
\hline & Dissolved + Colloid & 1.0 & 1.0 & 1.0 & 1.0 & ${ }^{1} 0.30$ & 1.0 \\
\hline & Whole Water, TR & 1.0 & 1.0 & 1.0 & 1.0 & ${ }^{1} 0.30$ & 1.0 \\
\hline \multirow[t]{4}{*}{ Flat Cr. } & Dissolved & $\overline{\mathrm{NA}}$ & $\overline{\mathrm{NA}}$ & NA & 0.0042 & NA & 0.00069 \\
\hline & Colloid & NA & NA & NA & NA & NA & NA \\
\hline & Dissolved + Colloid & NA & NA & NA & NA & NA & NA \\
\hline & Whole Water, TR & NA & NA & NA & 0.00050 & NA & 0.00037 \\
\hline \multirow[t]{4}{*}{ Spring Cr.-Weir } & Dissolved & NA & NA & NA & 1.9 & NA & 0.54 \\
\hline & Colloid & NA & NA & NA & 0.0008 & NA & 0.0017 \\
\hline & Dissolved + Colloid & NA & NA & NA & 0.28 & NA & 0.15 \\
\hline & Whole Water, TR & NA & NA & NA & 0.18 & NA & 0.19 \\
\hline \multirow[t]{4}{*}{ Spring Cr.-Road } & Dissolved & $\overline{\mathrm{NA}}$ & NA & $\overline{\mathrm{NA}}$ & NA & 5.8 & NA \\
\hline & Colloid & NA & NA & NA & NA & 0.00025 & NA \\
\hline & Dissolved + Colloid & NA & NA & NA & NA & 0.27 & NA \\
\hline & Whole Water, TR & NA & NA & NA & NA & 0.30 & NA \\
\hline Whiskeytown & Dissolved & NA & NA & NA & 0.093 & NA & 0.10 \\
\hline \multirow[t]{3}{*}{ Lake at SCPP } & Colloid & NA & NA & NA & NA & NA & NA \\
\hline & Dissolved + Colloid & NA & NA & NA & NA & NA & NA \\
\hline & Whole Water, TR & NA & NA & NA & 0.0093 & NA & 0.10 \\
\hline \multirow[t]{4}{*}{ Spring Cr. arm } & Dissolved & 0.17 & 0.28 & 1.9 & 3.6 & NA & 0.42 \\
\hline & Colloid & NA & NA & 0.25 & 0.10 & NA & 0.12 \\
\hline & Dissolved + Colloid & 0.025 & NA & 0.97 & 0.62 & NA & 0.19 \\
\hline & Whole Water, TR & 0.030 & 0.13 & 0.85 & 0.48 & NA & 0.32 \\
\hline \multirow[t]{4}{*}{ Colusa Basin Drain } & Dissolved & NA & NA & NA & NA & NA & 0.028 \\
\hline & Colloid & NA & NA & NA & NA & NA & 0.11 \\
\hline & Dissolved + Colloid & NA & NA & NA & NA & NA & 0.091 \\
\hline & Whole Water, TR & NA & NA & NA & NA & NA & 0.065 \\
\hline \multirow[t]{4}{*}{ Yolo Bypass } & Dissolved & NA & NA & $\overline{\mathrm{NA}}$ & $\overline{\mathrm{NA}}$ & 0.65 & NA \\
\hline & Colloid & NA & NA & NA & NA & 0.70 & NA \\
\hline & Dissolved + Colloid & NA & NA & NA & NA & 0.70 & NA \\
\hline & Whole Water, TR & NA & NA & NA & NA & 0.70 & NA \\
\hline
\end{tabular}

${ }^{1}$ Samples collected at Tower Bridge in January 1997. 
Table A2-3. Copper loads divided by sum of loads at Freeport and in Yolo Bypass, derived from concentrations in dissolved, colloid, and whole water samples

[Br., Bridge; Cr., Creek; NA, not analyzed; R., River; Sac., Sacramento; SCPP, Spring Creek Power Plant; TR, total recoverable analysis]

\begin{tabular}{|c|c|c|c|c|c|c|c|}
\hline \multirow{2}{*}{ Site } & & \multicolumn{6}{|c|}{ Sampling Periods } \\
\hline & & $\begin{array}{l}\text { July } \\
1996\end{array}$ & $\begin{array}{l}\text { Sept. } \\
1996\end{array}$ & $\begin{array}{l}\text { Nov. } \\
1996\end{array}$ & $\begin{array}{l}\text { Dec. } \\
1996\end{array}$ & $\begin{array}{l}\text { Jan. } \\
1997\end{array}$ & $\begin{array}{c}\text { May-June } \\
1997\end{array}$ \\
\hline \multirow{4}{*}{ Sac R.-Shasta } & Dissolved & 0.77 & 0.65 & 0.36 & 0.62 & NA & 0.35 \\
\hline & Colloid & NA & NA & 0.10 & 0.13 & NA & 0.20 \\
\hline & Dissolved + Colloid & 0.13 & NA & 0.18 & 0.20 & NA & 0.22 \\
\hline & Whole Water, TR & 0.42 & 0.31 & 0.21 & 0.34 & NA & 0.30 \\
\hline \multirow[t]{4}{*}{ Sac R.-Keswick } & Dissolved & 0.74 & 0.80 & 0.77 & 0.93 & 0.41 & 0.88 \\
\hline & Colloid & NA & NA & 0.85 & 0.24 & 0.088 & 0.34 \\
\hline & Dissolved + Colloid & 0.13 & NA & 0.82 & 0.35 & 0.11 & 0.42 \\
\hline & Whole Water, TR & 0.43 & 0.45 & 0.82 & 0.72 & 0.14 & 0.53 \\
\hline \multirow[t]{4}{*}{ Sac R.-Bend Br. } & Dissolved & 0.82 & 0.51 & 0.92 & 0.66 & 0.36 & 0.88 \\
\hline & Colloid & NA & NA & 3.8 & 0.86 & 0.31 & 0.37 \\
\hline & Dissolved + Colloid & 0.19 & 0.064 & 2.9 & 0.83 & 0.31 & 0.46 \\
\hline & Whole Water, TR & 0.48 & 0.49 & 1.2 & 0.94 & 0.33 & 0.60 \\
\hline \multirow[t]{4}{*}{ Sac R.-Colusa } & Dissolved & NA & 0.80 & 0.71 & 0.33 & 0.27 & 1.0 \\
\hline & Colloid & NA & NA & 2.5 & 1.6 & 0.42 & 0.78 \\
\hline & Dissolved + Colloid & NA & 0.38 & 1.9 & 1.4 & 0.40 & 0.80 \\
\hline & Whole Water, TR & 1.1 & 0.73 & 0.57 & 0.88 & 0.44 & 0.82 \\
\hline \multirow[t]{4}{*}{ Sac R.-Verona } & Dissolved & 0.79 & 1.5 & NA & 0.86 & NA & 0.94 \\
\hline & Colloid & NA & NA & 3.5 & 1.3 & NA & 1.1 \\
\hline & Dissolved + Colloid & 0.94 & 0.85 & NA & 1.3 & NA & 1.0 \\
\hline & Whole Water, TR & 1.0 & 1.6 & 1.3 & 0.8 & NA & 1.2 \\
\hline \multirow[t]{4}{*}{ Sac R.-Freeport } & Dissolved & 1.0 & 1.0 & 1.0 & 1.0 & ${ }^{1} 0.44$ & 1.0 \\
\hline & Colloid & NA & NA & 1.0 & 1.0 & ${ }^{1} 0.35$ & 1.0 \\
\hline & Dissolved + Colloid & 1.0 & 1.0 & 1.0 & 1.0 & ${ }^{1} 0.36$ & 1.0 \\
\hline & Whole Water, TR & 1.0 & 1.0 & 1.0 & 1.0 & ${ }^{1} 0.33$ & 1.0 \\
\hline \multirow[t]{4}{*}{ Flat Cr. } & Dissolved & NA & NA & NA & 0.00058 & NA & 0.00010 \\
\hline & Colloid & NA & NA & NA & NA & NA & NA \\
\hline & Dissolved + Colloid & NA & NA & NA & NA & NA & NA \\
\hline & Whole Water, TR & NA & NA & NA & 0.00032 & NA & 0.000069 \\
\hline \multirow[t]{4}{*}{ Spring Cr.-Weir } & Dissolved & NA & NA & NA & 1.5 & NA & 0.69 \\
\hline & Colloid & NA & NA & NA & 0.0019 & NA & 0.0069 \\
\hline & Dissolved + Colloid & NA & NA & NA & 0.24 & NA & 0.11 \\
\hline & Whole Water, TR & NA & NA & NA & 0.22 & NA & 0.13 \\
\hline \multirow[t]{4}{*}{ Spring Cr.-Road } & Dissolved & NA & NA & NA & NA & 1.7 & NA \\
\hline & Colloid & NA & NA & NA & NA & 0.00059 & NA \\
\hline & Dissolved + Colloid & NA & NA & NA & NA & 0.092 & NA \\
\hline & Whole Water, TR & NA & NA & NA & NA & 0.11 & NA \\
\hline Whiskeytown & Dissolved & NA & NA & NA & 0.044 & NA & 0.17 \\
\hline \multirow[t]{3}{*}{ Lake at SCPP } & Colloid & NA & NA & NA & NA & NA & NA \\
\hline & Dissolved + Colloid & NA & NA & NA & NA & NA & NA \\
\hline & Whole Water, TR & NA & NA & NA & 0.012 & NA & 0.12 \\
\hline Spring Cr. arm & Dissolved & 0.25 & 0.19 & 0.65 & 0.65 & NA & 0.23 \\
\hline & Colloid & NA & NA & 0.81 & 0.58 & NA & 0.18 \\
\hline & Dissolved + Colloid & 0.030 & NA & 0.74 & 0.59 & NA & 0.19 \\
\hline & Whole Water, TR & 0.043 & 0.10 & 0.59 & 0.52 & NA & 0.24 \\
\hline Colusa Basin Drain & Dissolved & NA & NA & NA & NA & NA & 0.10 \\
\hline & Colloid & NA & NA & NA & NA & NA & 0.19 \\
\hline & Dissolved + Colloid & NA & NA & NA & NA & NA & 0.17 \\
\hline & Whole Water, TR & NA & NA & NA & NA & NA & 0.16 \\
\hline Yolo Bypass & Dissolved & NA & NA & NA & NA & 0.56 & NA \\
\hline & Colloid & NA & NA & NA & NA & 0.65 & NA \\
\hline & Dissolved + Colloid & NA & NA & NA & NA & 0.64 & NA \\
\hline & Whole Water, TR & NA & NA & NA & NA & 0.67 & NA \\
\hline
\end{tabular}

${ }^{1}$ Samples collected at Tower Bridge in January 1997.

76 Metals Transport in the Sacramento River, California, 1996-1997. Volume 2: Interpretation of Metal Loads 
Table A2-4. Iron loads divided by sum of loads at Freeport and in Yolo Bypass, derived from concentrations in dissolved, colloid, and whole water samples

[Br., Bridge; Cr., Creek; NA, not analyzed; Sac., Sacramento; R., SCPP, Spring Creek Power Plant; River; TR, total recoverable analysis]

\begin{tabular}{|c|c|c|c|c|c|c|c|}
\hline \multirow{2}{*}{ Site } & & \multicolumn{6}{|c|}{ Sampling Periods } \\
\hline & & $\begin{array}{l}\text { July } \\
1996\end{array}$ & $\begin{array}{l}\text { Sept. } \\
1996\end{array}$ & $\begin{array}{l}\text { Nov. } \\
1996\end{array}$ & $\begin{array}{l}\text { Dec. } \\
1996\end{array}$ & $\begin{array}{l}\text { Jan. } \\
1997\end{array}$ & $\begin{array}{c}\text { May-June } \\
1997\end{array}$ \\
\hline \multirow[t]{4}{*}{ Sac R.-Shasta } & Dissolved & 1.2 & 0.62 & 0.66 & 0.32 & NA & 0.55 \\
\hline & Colloid & NA & NA & 0.041 & 0.014 & NA & 0.21 \\
\hline & Dissolved + Colloid & 0.071 & NA & 0.042 & 0.014 & NA & 0.21 \\
\hline & Whole Water, TR & 0.10 & 0.042 & 0.038 & 0.016 & NA & 0.20 \\
\hline \multirow[t]{4}{*}{ Sac R.-Keswick } & Dissolved & 0.35 & 0.30 & 0.84 & 0.33 & 0.14 & 0.93 \\
\hline & Colloid & NA & NA & 0.30 & 0.029 & 0.017 & 0.36 \\
\hline & Dissolved + Colloid & 0.07 & $\mathrm{NA}$ & 0.30 & 0.031 & 0.017 & 0.36 \\
\hline & Whole Water, TR & 0.10 & 0.05 & 0.25 & 0.034 & 0.014 & 0.34 \\
\hline \multirow[t]{4}{*}{ Sac R.-Bend Br. } & Dissolved & 0.50 & 0.22 & 1.7 & 0.41 & 0.28 & 0.33 \\
\hline & Colloid & NA & NA & 0.83 & 0.44 & 0.28 & 0.39 \\
\hline & Dissolved + Colloid & 0.10 & 0.076 & 0.83 & 0.44 & 0.28 & 0.39 \\
\hline & Whole Water, TR & 0.16 & 0.14 & 0.92 & 0.54 & 0.26 & 0.35 \\
\hline \multirow[t]{4}{*}{ Sac R.-Colusa } & Dissolved & NA & 0.41 & 1.1 & 0.26 & 0.18 & 0.29 \\
\hline & Colloid & NA & NA & 1.6 & 1.3 & 0.50 & 0.80 \\
\hline & Dissolved + Colloid & NA & 0.30 & 1.6 & 1.3 & 0.50 & 0.79 \\
\hline & Whole Water, TR & 1.5 & 0.59 & 0.92 & 0.78 & 0.48 & 0.86 \\
\hline \multirow[t]{4}{*}{ Sac R.-Verona } & Dissolved & 0.50 & 0.40 & NA & 0.88 & NA & 1.0 \\
\hline & Colloid & NA & NA & 2.8 & 1.1 & NA & 1.3 \\
\hline & Dissolved + Colloid & 0.65 & 1.3 & NA & 1.1 & NA & 1.3 \\
\hline & Whole Water, TR & 1.0 & 2.6 & 2.1 & 0.7 & NA & 1.3 \\
\hline \multirow[t]{4}{*}{ Sac R.-Freeport } & Dissolved & 1.0 & 1.0 & 1.0 & 1.0 & ${ }^{1} 0.40$ & 1.0 \\
\hline & Colloid & $\mathrm{NA}$ & $\mathrm{NA}$ & 1.0 & 1.0 & ${ }^{1} 0.36$ & 1.0 \\
\hline & Dissolved + Colloid & 1.0 & 1.0 & 1.0 & 1.0 & ${ }^{1} 0.36$ & 1.0 \\
\hline & Whole Water, TR & 1.0 & 1.0 & 1.0 & 1.0 & ${ }^{1} 0.31$ & 1.0 \\
\hline \multirow[t]{4}{*}{ Flat $\mathrm{Cr}$. } & Dissolved & NA & NA & NA & 0.00014 & NA & 0.0040 \\
\hline & Colloid & NA & NA & NA & NA & NA & NA \\
\hline & Dissolved + Colloid & $\mathrm{NA}$ & $\mathrm{NA}$ & NA & NA & NA & NA \\
\hline & Whole Water, TR & NA & NA & NA & 0.000015 & NA & 0.000043 \\
\hline \multirow[t]{4}{*}{ Spring Cr.-Weir } & Dissolved & NA & NA & NA & 0.70 & NA & 0.19 \\
\hline & Colloid & NA & NA & NA & 0.00076 & NA & 0.025 \\
\hline & Dissolved + Colloid & NA & NA & NA & 0.0018 & NA & 0.025 \\
\hline & Whole Water, TR & $\mathrm{NA}$ & $\mathrm{NA}$ & NA & 0.0017 & NA & 0.0016 \\
\hline \multirow[t]{4}{*}{ Spring Cr.-Road } & Dissolved & $\mathrm{NA}$ & $\mathrm{NA}$ & NA & NA & 6.0 & NA \\
\hline & Colloid & NA & NA & NA & NA & 0.00081 & NA \\
\hline & Dissolved + Colloid & NA & NA & NA & NA & 0.0045 & NA \\
\hline & Whole Water, TR & NA & NA & NA & NA & 0.0044 & NA \\
\hline \multirow{4}{*}{$\begin{array}{l}\text { Whiskeytown } \\
\text { Lake at SCPP }\end{array}$} & Dissolved & $\mathrm{NA}$ & NA & NA & 0.030 & NA & 0.25 \\
\hline & Colloid & $\mathrm{NA}$ & NA & NA & NA & NA & NA \\
\hline & Dissolved + Colloid & NA & NA & NA & NA & NA & NA \\
\hline & Whole Water, TR & NA & NA & NA & 0.00093 & NA & 0.13 \\
\hline \multirow[t]{4}{*}{ Spring Cr. arm } & Dissolved & 0.045 & 0.13 & 0.41 & 0.10 & NA & 0.41 \\
\hline & Colloid & NA & NA & 0.068 & 0.0073 & NA & 0.15 \\
\hline & Dissolved + Colloid & 0.0021 & NA & 0.069 & 0.0073 & NA & 0.15 \\
\hline & Whole Water, TR & 0.0048 & 0.013 & 0.058 & 0.0049 & NA & 0.13 \\
\hline \multirow[t]{4}{*}{ Colusa Basin Drain } & Dissolved & NA & NA & NA & NA & NA & 0.052 \\
\hline & Colloid & NA & NA & NA & NA & NA & 0.32 \\
\hline & Dissolved + Colloid & NA & NA & NA & NA & NA & 0.32 \\
\hline & Whole Water, TR & $\mathrm{NA}$ & NA & NA & $\mathrm{NA}$ & NA & 0.30 \\
\hline \multirow[t]{4}{*}{ Yolo Bypass } & Dissolved & $\mathrm{NA}$ & $\mathrm{NA}$ & NA & $\mathrm{NA}$ & 0.60 & NA \\
\hline & Colloid & NA & NA & NA & NA & 0.64 & NA \\
\hline & Dissolved + Colloid & $\mathrm{NA}$ & NA & NA & NA & 0.64 & NA \\
\hline & Whole Water, TR & NA & NA & NA & NA & 0.69 & NA \\
\hline
\end{tabular}

${ }^{1}$ Samples collected at Tower Bridge in January 1997. 
Table A2-5. Lead loads divided by sum of loads at Freeport and in Yolo Bypass, derived from concentrations in dissolved, colloid, and whole water samples

[Br., Bridge; Cr., Creek; NA, not analyzed; R., River; Sac., Sacramento; SCPP, Spring Creek Power Plant; TR, total recoverable analysis]

\begin{tabular}{|c|c|c|c|c|c|c|c|}
\hline \multirow{2}{*}{ Site } & & \multicolumn{6}{|c|}{ Sampling Periods } \\
\hline & & July & Sept. & Nov. & Dec. & Jan. & May-June \\
\hline \multirow{5}{*}{ Sac R.-Shasta } & Dissolved & 0.12 & 032 & 0.34 & 0.38 & $\mathrm{NA}$ & 046 \\
\hline & Colloid & $\mathrm{NA}$ & $\mathrm{Na}$ & 0.044 & 0.026 & sis & 0.12 \\
\hline & Discolved + Colloid & 1 090 & NA & 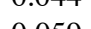 & 0.020 & NA & 0.15 \\
\hline & Dissolved + Colloid & 0.040 & NA & 0.059 & 0.029 & NA & 0.13 \\
\hline & Whole Water, TR & 0.094 & 0.062 & 0.061 & 0.045 & NA & 0.15 \\
\hline \multirow[t]{4}{*}{ Sac R.-Keswick } & Dissolved & 0.26 & 0.73 & 0.39 & 2.7 & 0.092 & 0.71 \\
\hline & Colloid & NA & NA & 0.77 & 0.081 & 0.022 & 0.19 \\
\hline & Dissolved + Colloid & 0.056 & NA & 0.75 & 0.10 & 0.023 & 0.20 \\
\hline & Whole Water, TR & 0.16 & 0.11 & 0.86 & 0.13 & 0.023 & 0.22 \\
\hline \multirow[t]{4}{*}{ Sac R.-Bend Br. } & Dissolved & 0.20 & 0.37 & 1.0 & 0.57 & 0.16 & 0.71 \\
\hline & Colloid & NA & NA & 1.4 & 0.42 & 0.26 & 0.29 \\
\hline & Dissolved + Colloid & 0.090 & 0.067 & 1.4 & 0.42 & 0.26 & 0.30 \\
\hline & Whole Water, TR & 0.19 & 0.19 & 1.8 & 0.49 & 0.21 & 0.33 \\
\hline \multirow[t]{4}{*}{ Sac R.-Colusa } & Dissolved & NA & 0.50 & 0.68 & 0.48 & 0.11 & 0.67 \\
\hline & Colloid & NA & NA & 2.3 & 1.1 & 0.40 & 0.73 \\
\hline & Dissolved + Colloid & NA & 0.32 & 2.2 & 1.1 & 0.40 & 0.79 \\
\hline & Whole Water, TR & 1.1 & 0.44 & 0.80 & 1.3 & 0.40 & 0.64 \\
\hline \multirow[t]{4}{*}{ Sac R.-Verona } & Dissolved & 0.45 & 0.5 & NA & 1.3 & NA & 0.86 \\
\hline & Colloid & NA & NA & 3.3 & 1.0 & NA & 1.2 \\
\hline & Dissolved + Colloid & 0.70 & 0.85 & NA & 1.0 & NA & 1.2 \\
\hline & Whole Water, TR & 0.89 & 1.6 & 2.1 & 1.0 & NA & 1.1 \\
\hline \multirow[t]{4}{*}{ Sac R.-Freeport } & Dissolved & 1.0 & 1.0 & 1.0 & 1.0 & ${ }^{1} 0.23$ & 1.0 \\
\hline & Colloid & NA & NA & 1.0 & 1.0 & ${ }^{1} 0.48$ & 1.0 \\
\hline & Dissolved + Colloid & 1.0 & 1.0 & 1.0 & 1.0 & ${ }^{1} 0.48$ & 1.1 \\
\hline & Whole Water, TR & 1.0 & 1.0 & 1.0 & 1.0 & ${ }^{1} 0.42$ & 1.0 \\
\hline \multirow[t]{4}{*}{ Flat Cr. } & Dissolved & NA & NA & NA & 0.00030 & NA & 0.000048 \\
\hline & Colloid & NA & NA & NA & NA & NA & NA \\
\hline & Dissolved + Colloid & NA & NA & NA & NA & NA & NA \\
\hline & Whole Water, TR & NA & NA & NA & 0.000026 & NA & 0.0000078 \\
\hline \multirow[t]{4}{*}{ Spring Cr.-Weir } & Dissolved & NA & NA & NA & 0.49 & $\overline{\mathrm{NA}}$ & 0.35 \\
\hline & Colloid & NA & NA & NA & 0.0014 & NA & 0.014 \\
\hline & Dissolved + Colloid & NA & NA & NA & 0.0048 & NA & 0.019 \\
\hline & Whole Water, TR & NA & NA & NA & 0.0034 & NA & 0.0077 \\
\hline \multirow[t]{4}{*}{ Spring Cr.-Road } & Dissolved & NA & NA & NA & NA & 1.1 & NA \\
\hline & Colloid & NA & NA & NA & NA & 0.00061 & NA \\
\hline & Dissolved + Colloid & NA & NA & NA & NA & 0.0036 & NA \\
\hline & Whole Water, TR & NA & NA & NA & NA & 0.0035 & NA \\
\hline Whiskeytown & Dissolved & NA & NA & NA & 0.078 & NA & 0.10 \\
\hline \multirow{3}{*}{ Lake at SCPP } & Colloid & NA & NA & NA & NA & NA & NA \\
\hline & Dissolved + Colloid & NA & NA & NA & NA & NA & NA \\
\hline & Whole Water, TR & NA & NA & NA & 0.0029 & NA & 0.064 \\
\hline \multirow[t]{4}{*}{ Spring Cr. arm } & Dissolved & 0.047 & 0.29 & 0.089 & 0.076 & NA & 0.22 \\
\hline & Colloid & NA & NA & 0.083 & 0.018 & NA & 0.046 \\
\hline & Dissolved + Colloid & 0.0031 & NA & 0.085 & 0.018 & NA & 0.049 \\
\hline & Whole Water, TR & 0.011 & 0.024 & 0.084 & 0.013 & NA & 0.046 \\
\hline \multirow[t]{4}{*}{ Colusa Basin Drain } & Dissolved & NA & NA & NA & NA & $\mathrm{NA}$ & 0.057 \\
\hline & Colloid & NA & NA & NA & NA & NA & 0.23 \\
\hline & Dissolved + Colloid & NA & NA & NA & NA & NA & 0.24 \\
\hline & Whole Water, TR & NA & NA & NA & NA & NA & 0.22 \\
\hline \multirow[t]{4}{*}{ Yolo Bypass } & Dissolved & NA & NA & NA & NA & 0.77 & NA \\
\hline & Colloid & NA & NA & NA & NA & 0.52 & NA \\
\hline & Dissolved + Colloid & NA & NA & NA & NA & 0.52 & NA \\
\hline & Whole Water, TR & NA & NA & NA & NA & 0.58 & NA \\
\hline
\end{tabular}

${ }^{1}$ Samples collected at Tower Bridge in January 1997. 
Table A2-6. Mercury loads divided by sum of loads at Freeport and in Yolo Bypass, derived from concentrations in dissolved, colloid, and whole water samples

[Br., Bridge; Cr., Creek; NA, not analyzed; R., River; Sac., Sacramento; SCPP, Spring Creek Power Plant; TR, total recoverable analysis]

\begin{tabular}{|c|c|c|c|c|c|c|c|}
\hline \multirow{2}{*}{ Site } & & \multicolumn{6}{|c|}{ Sampling Periods } \\
\hline & & $\begin{array}{l}\text { July } \\
1996\end{array}$ & $\begin{array}{l}\text { Sept. } \\
1996\end{array}$ & $\begin{array}{l}\text { Nov. } \\
1996\end{array}$ & $\begin{array}{l}\text { Dec. } \\
1996\end{array}$ & $\begin{array}{l}\text { Jan. } \\
1997\end{array}$ & $\begin{array}{c}\text { May-June } \\
1997\end{array}$ \\
\hline \multirow[t]{4}{*}{ Sac R.-Shasta } & Dissolved & 0.66 & 0.75 & 0.29 & 0.53 & NA & 0.59 \\
\hline & Colloid & NA & NA & 0.076 & 0.039 & NA & 0.18 \\
\hline & Dissolved + Colloid & NA & NA & 0.13 & 0.081 & NA & 0.27 \\
\hline & Whole Water, TR & 0.11 & 0.089 & 0.19 & 0.037 & NA & 0.24 \\
\hline \multirow[t]{4}{*}{ Sac R.-Keswick } & Dissolved & 0.80 & 0.62 & 0.64 & 0.47 & 0.053 & 0.56 \\
\hline & Colloid & NA & NA & 0.39 & 0.094 & 0.034 & 0.41 \\
\hline & Dissolved + Colloid & NA & NA & 0.46 & 0.12 & 0.035 & 0.44 \\
\hline & Whole Water, TR & 0.20 & 0.24 & 0.61 & 0.08 & 0.033 & 0.55 \\
\hline \multirow[t]{4}{*}{ Sac R.-Bend Br. } & Dissolved & 0.80 & 0.72 & 0.68 & 0.61 & 0.20 & 0.81 \\
\hline & Colloid & NA & NA & 1.1 & 0.36 & 0.26 & 0.37 \\
\hline & Dissolved + Colloid & NA & NA & 1.0 & 0.38 & 0.26 & 0.46 \\
\hline & Whole Water, TR & 0.28 & 0.38 & 1.3 & 0.41 & 0.09 & 0.44 \\
\hline \multirow[t]{4}{*}{ Sac R.-Colusa } & Dissolved & NA & 0.69 & 0.50 & 0.36 & 0.23 & 0.34 \\
\hline & Colloid & NA & NA & 3.1 & 1.1 & 0.47 & 0.92 \\
\hline & Dissolved + Colloid & NA & NA & 2.4 & 1.0 & 0.45 & 0.80 \\
\hline & Whole Water, TR & 0.81 & 0.50 & 0.69 & 0.47 & 0.40 & 0.57 \\
\hline \multirow[t]{4}{*}{ Sac R.-Verona } & Dissolved & 0.95 & 1.5 & NA & 0.8 & NA & 0.75 \\
\hline & Colloid & NA & NA & 2.2 & 1.0 & NA & 1.6 \\
\hline & Dissolved + Colloid & NA & NA & NA & 1.0 & NA & 1.4 \\
\hline & Whole Water, TR & 0.86 & 2.4 & 0.9 & 0.6 & NA & 0.81 \\
\hline \multirow[t]{4}{*}{ Sac R.-Freeport } & Dissolved & 1.0 & 1.0 & 1.0 & 1.0 & ${ }^{1} 0.27$ & 1.0 \\
\hline & Colloid & NA & NA & 1.0 & 1.0 & ${ }^{1} 0.19$ & 1.0 \\
\hline & Dissolved + Colloid & NA & NA & 1.0 & 1.0 & ${ }^{1} 0.20$ & 1.0 \\
\hline & Whole Water, TR & 1.0 & 1.0 & 1.0 & 1.0 & ${ }^{1} 0.27$ & 1.0 \\
\hline \multirow[t]{4}{*}{ Flat Cr. } & Dissolved & NA & NA & NA & 0.00018 & NA & 0.00011 \\
\hline & Colloid & NA & NA & NA & NA & NA & NA \\
\hline & Dissolved + Colloid & NA & NA & NA & NA & NA & NA \\
\hline & Whole Water, TR & NA & NA & NA & 0.000050 & NA & 0.000043 \\
\hline \multirow[t]{4}{*}{ Spring Cr.-Weir } & Dissolved & $\overline{N A}$ & NA & NA & 0.0043 & NA & 0.0014 \\
\hline & Colloid & NA & NA & NA & 0.0047 & NA & 0.0046 \\
\hline & Dissolved + Colloid & NA & NA & NA & 0.0047 & NA & 0.0040 \\
\hline & Whole Water, TR & NA & NA & NA & 0.0037 & NA & 0.0014 \\
\hline \multirow[t]{4}{*}{ Spring Cr.-Road } & Dissolved & NA & NA & NA & NA & 0.0032 & NA \\
\hline & Colloid & NA & NA & NA & NA & 0.0047 & NA \\
\hline & Dissolved + Colloid & NA & NA & NA & NA & 0.0045 & NA \\
\hline & Whole Water, TR & NA & NA & NA & NA & 0.0034 & NA \\
\hline Whiskeytown & Dissolved & $\overline{\mathrm{NA}}$ & NA & NA & 0.054 & NA & 0.13 \\
\hline \multirow[t]{3}{*}{ Lake at SCPP } & Colloid & NA & NA & NA & NA & NA & NA \\
\hline & Dissolved + Colloid & NA & NA & NA & NA & NA & NA \\
\hline & Whole Water, TR & NA & NA & NA & 0.0051 & NA & 0.12 \\
\hline \multirow[t]{4}{*}{ Spring Cr. arm } & Dissolved & 0.14 & 0.24 & 0.13 & 0.029 & NA & 0.50 \\
\hline & Colloid & NA & NA & 0.078 & 0.026 & NA & 0.15 \\
\hline & Dissolved + Colloid & NA & NA & 0.092 & 0.026 & NA & 0.21 \\
\hline & Whole Water, TR & 0.037 & 0.072 & 0.084 & 0.018 & NA & 0.17 \\
\hline \multirow[t]{4}{*}{ Colusa Basin Drain } & Dissolved & NA & NA & NA & NA & NA & 0.028 \\
\hline & Colloid & NA & NA & NA & NA & NA & 0.15 \\
\hline & Dissolved + Colloid & NA & NA & NA & NA & NA & 0.12 \\
\hline & Whole Water, TR & NA & NA & NA & NA & NA & 0.069 \\
\hline \multirow[t]{4}{*}{ Yolo Bypass } & Dissolved & NA & NA & NA & NA & 0.73 & NA \\
\hline & Colloid & NA & NA & NA & NA & 0.81 & NA \\
\hline & Dissolved + Colloid & NA & NA & NA & NA & 0.83 & NA \\
\hline & Whole Water, TR & NA & NA & NA & NA & 0.73 & NA \\
\hline
\end{tabular}

${ }^{1}$ Samples collected at Tower Bridge in January 1997. 
Table A2-7. Zinc loads divided by sum of loads at Freeport and in Yolo Bypass, derived from concentrations in dissolved, colloid, and whole water samples

[Br., Bridge; Cr., Creek; NA, not analyzed; R., River; Sac., Sacramento; SCPP, Spring Creek Power Plant; TR, total recoverable analysis]

\begin{tabular}{|c|c|c|c|c|c|c|c|}
\hline \multirow{2}{*}{ Site } & & \multicolumn{6}{|c|}{ Sampling Periods } \\
\hline & & $\begin{array}{l}\text { July } \\
1996\end{array}$ & $\begin{array}{l}\text { Sept. } \\
1996\end{array}$ & $\begin{array}{l}\text { Nov. } \\
1996\end{array}$ & $\begin{array}{l}\text { Dec. } \\
1996\end{array}$ & $\begin{array}{l}\text { Jan. } \\
1997\end{array}$ & $\begin{array}{c}\text { May-June } \\
1997\end{array}$ \\
\hline \multirow[t]{4}{*}{ Sac R.-Shasta } & Dissolved & 3.7 & 1.4 & 0.60 & 3.7 & NA & 1.0 \\
\hline & Colloid & NA & NA & 0.12 & 0.085 & NA & 0.27 \\
\hline & Dissolved + Colloid & 0.22 & NA & 0.25 & 0.27 & NA & 0.33 \\
\hline & Whole Water, TR & 0.65 & 0.85 & 0.28 & 0.35 & NA & 0.43 \\
\hline \multirow[t]{4}{*}{ Sac R.-Keswick } & Dissolved & 4.1 & 1.3 & 1.9 & 6.0 & 3.6 & 3.6 \\
\hline & Colloid & NA & NA & 0.70 & 0.22 & 0.10 & 0.55 \\
\hline & Dissolved + Colloid & 0.25 & NA & 1.0 & 0.51 & 0.15 & 0.75 \\
\hline & Whole Water, TR & 0.71 & 0.79 & 1.1 & 0.63 & 0.20 & 0.91 \\
\hline \multirow[t]{4}{*}{ Sac R.-Bend Br. } & Dissolved & 2.5 & 1.1 & 1.8 & 1.2 & 0.38 & 2.5 \\
\hline & Colloid & NA & NA & 1.5 & 1.0 & 0.43 & 0.62 \\
\hline & Dissolved + Colloid & 0.25 & 0.10 & 1.6 & 1.0 & 0.43 & 0.75 \\
\hline & Whole Water, TR & 0.76 & 1.1 & 1.8 & 0.87 & 0.39 & 0.91 \\
\hline \multirow[t]{4}{*}{ Sac R.-Colusa } & Dissolved & NA & 0.18 & 0.30 & 0.67 & 0.10 & 1.4 \\
\hline & Colloid & NA & NA & 2.1 & 1.8 & 0.57 & 1.1 \\
\hline & Dissolved + Colloid & NA & 0.14 & 1.7 & 1.8 & 0.56 & 1.1 \\
\hline & Whole Water, TR & 1.6 & 0.70 & 0.64 & 0.93 & 0.53 & 1.0 \\
\hline \multirow[t]{4}{*}{ Sac R.-Verona } & Dissolved & 0.45 & 0.27 & NA & 0.94 & NA & 1.0 \\
\hline & Colloid & NA & NA & 2.6 & 1.2 & NA & 1.3 \\
\hline & Dissolved + Colloid & 0.56 & 0.38 & $\mathrm{NA}$ & 1.2 & NA & 1.3 \\
\hline & Whole Water, TR & 1.1 & 1.8 & 1.1 & 0.73 & NA & 1.4 \\
\hline \multirow[t]{4}{*}{ Sac R.-Freeport } & Dissolved & 1.0 & 1.0 & 1.0 & 1.0 & ${ }^{1} 0.66$ & 1.0 \\
\hline & Colloid & NA & NA & 1.0 & 1.0 & ${ }^{1} 0.32$ & 1.0 \\
\hline & Dissolved + Colloid & 1.0 & 1.0 & 1.0 & 1.0 & ${ }^{1} 0.32$ & 1.0 \\
\hline & Whole Water, TR & 1.0 & 1.0 & 1.0 & 1.0 & ${ }^{1} 0.29$ & 1.0 \\
\hline \multirow[t]{4}{*}{ Flat Cr. } & Dissolved & NA & NA & NA & 0.0049 & NA & 0.0016 \\
\hline & Colloid & NA & NA & $\mathrm{NA}$ & NA & NA & NA \\
\hline & Dissolved + Colloid & NA & NA & NA & NA & NA & NA \\
\hline & Whole Water, TR & NA & NA & NA & 0.00047 & NA & 0.00017 \\
\hline \multirow[t]{4}{*}{ Spring Cr.-Weir } & Dissolved & NA & NA & NA & 3.9 & NA & 1.9 \\
\hline & Colloid & NA & NA & NA & 0.0011 & NA & 0.0014 \\
\hline & Dissolved + Colloid & NA & NA & NA & 0.20 & NA & 0.13 \\
\hline & Whole Water, TR & NA & NA & NA & 0.15 & NA & 0.20 \\
\hline \multirow[t]{4}{*}{ Spring Cr.-Road } & Dissolved & NA & NA & NA & NA & 11 & NA \\
\hline & Colloid & NA & NA & NA & NA & 0.00024 & NA \\
\hline & Dissolved + Colloid & NA & NA & NA & NA & 0.17 & NA \\
\hline & Whole Water, TR & NA & NA & NA & NA & 0.20 & NA \\
\hline Whiskeytown & Dissolved & $\overline{\mathrm{NA}}$ & NA & NA & 0.13 & NA & 0.15 \\
\hline \multirow[t]{3}{*}{ Lake at SCPP } & Colloid & NA & NA & NA & NA & NA & NA \\
\hline & Dissolved + Colloid & NA & NA & $\mathrm{NA}$ & NA & NA & NA \\
\hline & Whole Water, TR & NA & NA & NA & 0.0067 & NA & 0.065 \\
\hline \multirow[t]{4}{*}{ Spring Cr. arm } & Dissolved & 0.28 & 0.31 & 2.0 & 5.1 & $\mathrm{NA}$ & 1.3 \\
\hline & Colloid & NA & NA & 0.39 & 0.17 & NA & 0.17 \\
\hline & Dissolved + Colloid & 0.014 & NA & 0.81 & 0.42 & NA & 0.24 \\
\hline & Whole Water, TR & 0.035 & 0.20 & 0.74 & 0.40 & NA & 0.29 \\
\hline \multirow[t]{4}{*}{ Colusa Basin Drain } & Dissolved & NA & NA & NA & NA & NA & 0.034 \\
\hline & Colloid & NA & NA & NA & NA & NA & 0.22 \\
\hline & Dissolved + Colloid & NA & NA & $\mathrm{NA}$ & NA & NA & 0.21 \\
\hline & Whole Water, TR & NA & NA & NA & NA & NA & 0.21 \\
\hline \multirow[t]{4}{*}{ Yolo Bypass } & Dissolved & NA & NA & NA & NA & 0.34 & NA \\
\hline & Colloid & NA & NA & NA & NA & 0.68 & NA \\
\hline & Dissolved + Colloid & NA & NA & NA & NA & 0.67 & NA \\
\hline & Whole Water, TR & NA & NA & $\mathrm{NA}$ & NA & 0.71 & NA \\
\hline
\end{tabular}

${ }^{1}$ Samples collected at Tower Bridge in January 1997.

80 Metals Transport in the Sacramento River, California, 1996-1997. Volume 2: Interpretation of Metal Loads 


\section{Appendix 3. Tables of Data Comparing Metal Loads Used in Mass Balance Calculations for the Spring Creek Arm of Keswick Reservoir}

Table A3-1. Aluminum loads derived from concentrations in dissolved, colloid, and whole water samples used in mass balance calculations for the Spring Creek arm of Keswick Reservoir

Table A3-2. Cadmium loads derived from concentrations in dissolved, colloid, and whole water samples used in mass balance calculations for the Spring Creek arm of Keswick Reservoir

Table A3-3. Copper loads derived from concentrations in dissolved, colloid, and whole water samples used in mass balance calculations for the Spring Creek arm of Keswick Reservoir

Table A3-4. Iron loads derived from concentrations in dissolved, colloid, and whole water samples used in mass balance calculations for the Spring Creek arm of Keswick Reservoir

Table A3-5. Lead loads derived from concentrations in dissolved, colloid, and whole water samples used in mass balance calculations for the Spring Creek arm of Keswick Reservoir

Table A3-6. Mercury loads derived from concentrations in dissolved, colloid, and whole water samples used in mass balance calculations for the Spring Creek arm of Keswick Reservoir

Table A3-7. Zinc loads derived from concentrations in dissolved, colloid, and whole water samples used in mass balance calculations for the Spring Creek arm of Keswick Reservoir 
Table A3-1. Aluminum loads derived from concentrations in dissolved, colloid, and whole water samples used in mass balance calculations for the Spring Creek arm of Keswick Reservoir

[kg, kilogram; d, day; Cr., Creek; NA, not analyzed; NC, not calculated; SCPP, Spring Creek Power Plant; TR, Total recoverable analysis. $\geq$, load is greater than or equal to value shown because colloids not analyzed from Whiskeytown Lake; \%, percent]

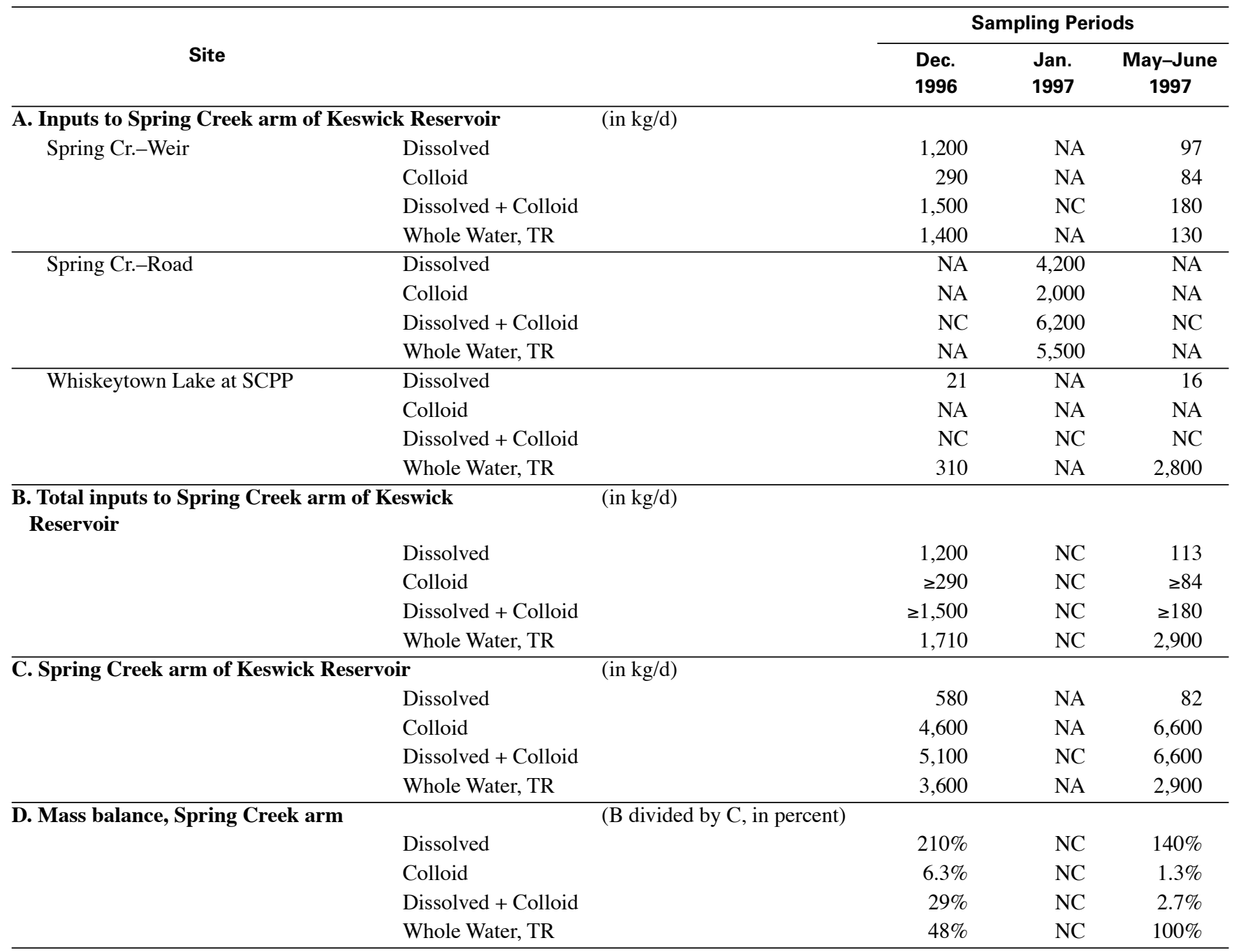


Table A3-2. Cadmium loads derived from concentrations in dissolved, colloid, and whole water samples used in mass balance calculations for the Spring Creek arm of Keswick Reservoir

[kg, kilogram; d, day; Cr., Creek; NA, not analyzed; NC, not calculated; SCPP, Spring Creek Power Plant; TR, Total recoverable analysis. \%, percent; $\leq$, load is less than or equal to value shown because of concentration less than detection limit; $\geq$, load is greater than or equal to value shown because colloids not analyzed from Whiskeytown Lake]

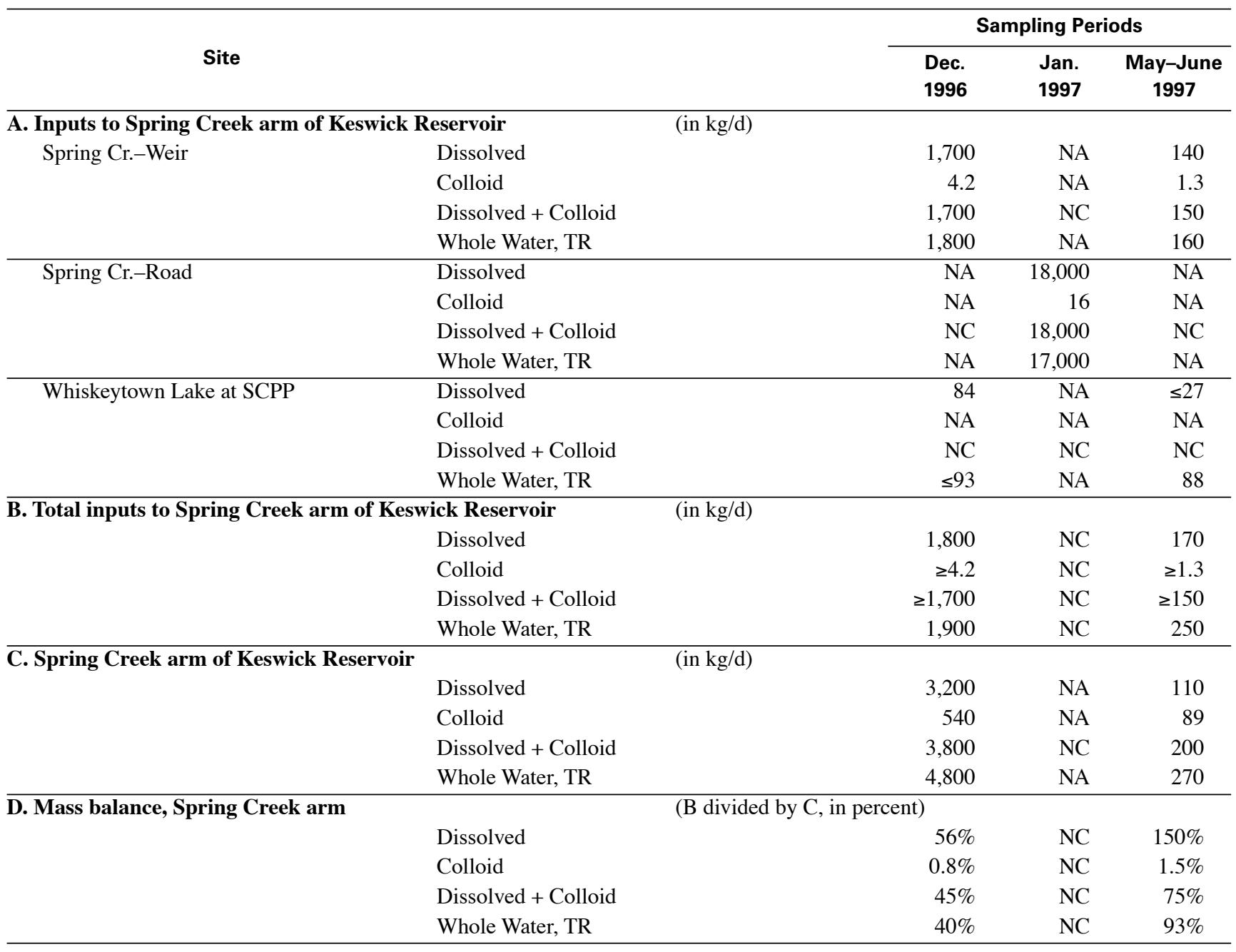


Table A3-3. Copper loads derived from concentrations in dissolved, colloid, and whole water samples used in mass balance calculations for the Spring Creek arm of Keswick Reservoir

[kg, kilogram; d, day; Cr., Creek; NA, not analyzed; NC, not calculated; SCPP, Spring Creek Power Plant; TR, Total recoverable analysis. $\%$, percent; $\geq$, load is greater than or equal to value shown because colloids not analyzed from Whiskeytown Lake]

\begin{tabular}{|c|c|c|c|c|}
\hline \multirow{2}{*}{ Site } & & \multicolumn{3}{|c|}{ Sampling Periods } \\
\hline & & $\begin{array}{l}\text { Dec. } \\
1996\end{array}$ & $\begin{array}{l}\text { Jan. } \\
997\end{array}$ & $\begin{array}{c}\text { May-June } \\
1997\end{array}$ \\
\hline \multicolumn{5}{|c|}{ A. Inputs to Spring Creek arm of Keswick Reservoir } \\
\hline \multirow[t]{4}{*}{ Spring Cr.-Weir } & Dissolved & 210 & NA & 11 \\
\hline & Colloid & 1.4 & NA & 0.63 \\
\hline & Dissolved + Colloid & 210 & $\mathrm{NC}$ & 12 \\
\hline & Whole Water, TR & 200 & NA & 12 \\
\hline \multirow[t]{4}{*}{ Spring Cr.-Road } & Dissolved & NA & 1,100 & NA \\
\hline & Colloid & NA & 6.7 & NA \\
\hline & Dissolved + Colloid & $\mathrm{NC}$ & 1,100 & NC \\
\hline & Whole Water, TR & NA & 1,100 & NA \\
\hline \multirow[t]{4}{*}{ Whiskeytown Lake at SCPP } & Dissolved & 6.2 & NA & 2.7 \\
\hline & Colloid & NA & NA & NA \\
\hline & Dissolved + Colloid & $\mathrm{NC}$ & $\mathrm{NC}$ & $\mathrm{NC}$ \\
\hline & Whole Water, TR & 11 & NA & 11 \\
\hline \multicolumn{5}{|c|}{ B. Total inputs to Spring Creek arm of Keswick Reservoir } \\
\hline & Dissolved & 220 & $\mathrm{NC}$ & 14 \\
\hline & Colloid & $\geq 1.4$ & $\mathrm{NC}$ & $\geq 0.63$ \\
\hline & Dissolved + Colloid & $\geq 220$ & $\mathrm{NC}$ & $\geq 12$ \\
\hline & Whole Water, TR & 210 & $\mathrm{NC}$ & 23 \\
\hline \multicolumn{5}{|c|}{ C. Spring Creek arm of Keswick Reservoir } \\
\hline & Dissolved & 91 & NA & 4 \\
\hline & Colloid & 430 & NA & 16 \\
\hline & Dissolved + Colloid & 520 & $\mathrm{NC}$ & 20 \\
\hline & Whole Water, TR & 480 & NA & 22 \\
\hline \multirow[t]{5}{*}{ D. Mass balance, Spring Creek } & & & & \\
\hline & Dissolved & $240 \%$ & $\mathrm{NC}$ & $380 \%$ \\
\hline & Colloid & $0.3 \%$ & $\mathrm{NC}$ & $3.9 \%$ \\
\hline & Dissolved + Colloid & $42 \%$ & $\mathrm{NC}$ & $60 \%$ \\
\hline & Whole Water, TR & $44 \%$ & $\mathrm{NC}$ & $100 \%$ \\
\hline
\end{tabular}


Table A3-4. Iron loads derived from concentrations in dissolved, colloid, and whole water samples used in mass balance calculations for the Spring Creek arm of Keswick Reservoir

[kg, kilogram; d, day; Cr., Creek; NA, not analyzed; NC, not calculated; SCPP, Spring Creek Power Plant; TR, Total recoverable analysis. $\%$, percent; $\geq$, load is greater than or equal to value shown because colloids not analyzed from Whiskeytown Lake]

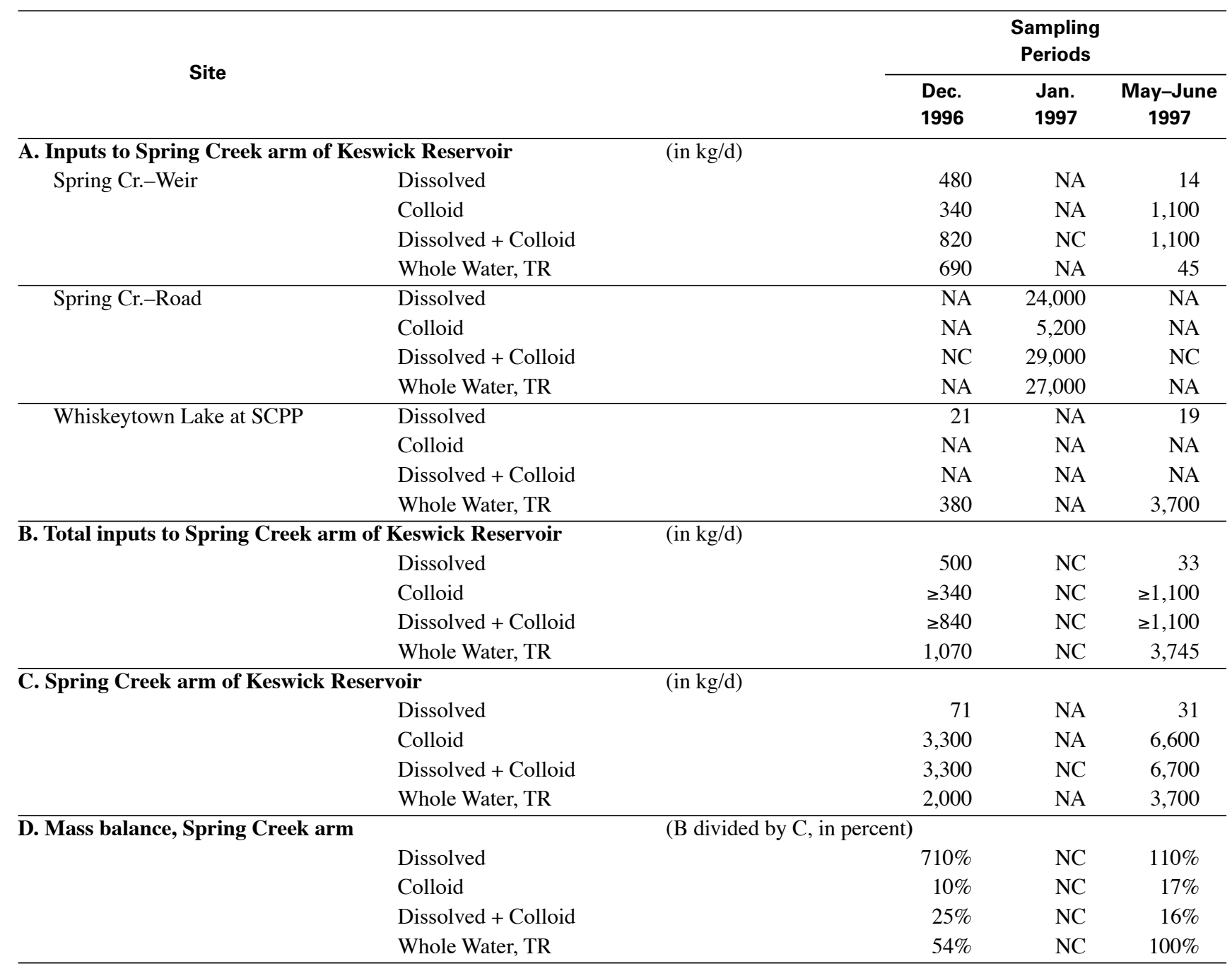


Table A3-5. Lead loads derived from concentrations in dissolved, colloid, and whole water samples used in mass balance calculations for the Spring Creek arm of Keswick Reservoir

[kg, kilogram; d, day; Cr., Creek; NA, not analyzed; NC, not calculated; SCPP, Spring Creek Power Plant; TR, Total recoverable analysis. $\%$ percent; $\leq$, load is less than or equal to value shown because of concentration less than detection limit; $\geq$, load is greater than or equal to value shown because colloids not analyzed from Whiskeytown Lake]

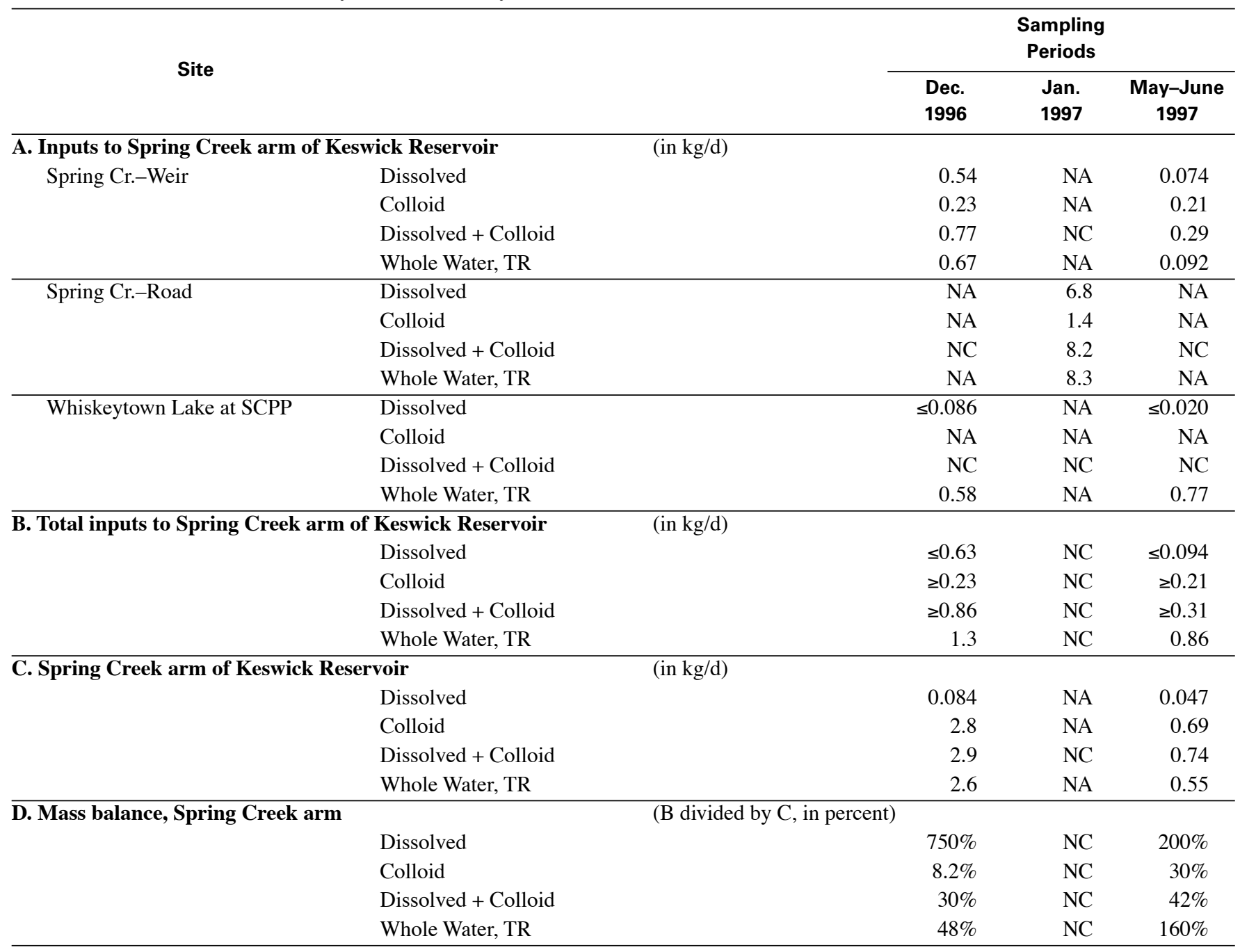


Table A3-6. Mercury loads derived from concentrations in dissolved, colloid, and whole water samples used in mass balance calculations for the Spring Creek arm of Keswick Reservoir

[g, gram; d, day; Cr., Creek; NA, not analyzed; NC, not calculated; SCPP, Spring Creek Power Plant; TR, Total recoverable analysis. $\%$, percent; $\geq$, load is greater than or equal to value shown because colloids not analyzed from Whiskeytown Lake]

\begin{tabular}{|c|c|c|c|c|}
\hline \multirow{2}{*}{ Site } & & \multicolumn{3}{|c|}{$\begin{array}{l}\text { Sampling } \\
\text { Periods }\end{array}$} \\
\hline & & $\begin{array}{l}\text { Dec. } \\
1996\end{array}$ & $\begin{array}{l}\text { Jan. } \\
1997\end{array}$ & $\begin{array}{c}\text { May-June } \\
1997\end{array}$ \\
\hline \multicolumn{5}{|c|}{ A. Inputs to Spring Creek arm of Keswick Reservoir } \\
\hline \multirow[t]{4}{*}{ Spring Cr.-Weir } & Dissolved & 0.69 & NA & 0.045 \\
\hline & Colloid & 8.0 & NA & 0.60 \\
\hline & Dissolved + Colloid & 8.7 & $\mathrm{NC}$ & 0.64 \\
\hline & Whole Water, TR & 6.6 & NA & 0.22 \\
\hline \multirow[t]{4}{*}{ Spring Cr.-Road } & Dissolved & NA & 1.9 & NA \\
\hline & Colloid & NA & 110 & NA \\
\hline & Dissolved + Colloid & $\mathrm{NC}$ & 110 & $\mathrm{NC}$ \\
\hline & Whole Water, TR & NA & 83 & NA \\
\hline \multirow[t]{4}{*}{ Whiskeytown Lake at SCPP } & Dissolved & 8.7 & NA & 4.3 \\
\hline & Colloid & $\mathrm{NC}$ & NA & $\mathrm{NC}$ \\
\hline & Dissolved + Colloid & 8.7 & $\mathrm{NC}$ & $\geq 4.3$ \\
\hline & Whole Water, TR & 9.1 & NA & 19 \\
\hline \multicolumn{5}{|c|}{ B. Total inputs to Spring Creek arm of Keswick Reservoir } \\
\hline & Dissolved & 9.4 & $\mathrm{NC}$ & 4.3 \\
\hline & Colloid & $\geq 8.0$ & $\mathrm{NC}$ & $\geq 0.60$ \\
\hline & Dissolved + Colloid & $\geq 17$ & $\mathrm{NC}$ & $\geq 4.9$ \\
\hline & Whole Water, TR & 16 & $\mathrm{NC}$ & 19 \\
\hline \multicolumn{5}{|c|}{ C. Spring Creek arm of Keswick Reservoir } \\
\hline & Dissolved & 4.6 & NA & 16 \\
\hline & Colloid & 44 & NA & 19 \\
\hline & Dissolved + Colloid & 49 & $\mathrm{NC}$ & 34 \\
\hline & Whole Water, TR & 33 & NA & 27 \\
\hline \multirow[t]{5}{*}{ D. Mass balance, Spring Creek } & & & & \\
\hline & Dissolved & $200 \%$ & $\mathrm{NC}$ & $27 \%$ \\
\hline & Colloid & $18 \%$ & $\mathrm{NC}$ & $3.2 \%$ \\
\hline & Dissolved + Colloid & $36 \%$ & $\mathrm{NC}$ & $15 \%$ \\
\hline & Whole Water, TR & $48 \%$ & $\mathrm{NC}$ & $71 \%$ \\
\hline
\end{tabular}


Table A3-7. Zinc loads derived from concentrations in dissolved, colloid, and whole water samples used in mass balance calculations for the Spring Creek arm of Keswick Reservoir

[kg, kilogram; d, day; Cr., Creek; NA, not analyzed; NC, not calculated; SCPP, Spring Creek Power Plant; TR, Total recoverable analysis. $\%$, percent; $\geq$, load is greater than or equal to value shown because colloids not analyzed from Whiskeytown Lake]

\begin{tabular}{|c|c|c|c|c|}
\hline \multirow{2}{*}{ Site } & & \multicolumn{3}{|c|}{ Sampling Periods } \\
\hline & & \multirow{2}{*}{$\begin{array}{l}\text { Dec. } \\
1996\end{array}$} & \multirow{2}{*}{$\begin{array}{l}\text { Jan. } \\
1997\end{array}$} & \multirow{2}{*}{$\begin{array}{c}\text { May-June } \\
1997\end{array}$} \\
\hline A. Inputs to Spring Creek arm & Reservoir & & & \\
\hline \multirow[t]{4}{*}{ Spring Cr.-Weir } & Dissolved & 270 & NA & 21 \\
\hline & Colloid & 1.4 & NA & 0.21 \\
\hline & Dissolved + Colloid & 270 & NA & 21 \\
\hline & Whole Water, TR & 230 & NA & 22 \\
\hline \multirow[t]{4}{*}{ Spring Cr.-Road } & Dissolved & NA & 2,600 & NA \\
\hline & Colloid & NA & 3.5 & NA \\
\hline & Dissolved + Colloid & $\mathrm{NC}$ & 2,600 & $\mathrm{NC}$ \\
\hline & Whole Water, TR & NA & 2,800 & NA \\
\hline \multirow[t]{4}{*}{ Whiskeytown Lake at SCPP } & Dissolved & 8.9 & NA & 1.7 \\
\hline & Colloid & NA & NA & $\mathrm{NC}$ \\
\hline & Dissolved + Colloid & $\mathrm{NC}$ & $\mathrm{NC}$ & $\mathrm{NC}$ \\
\hline & Whole Water, TR & 10 & NA & 7.1 \\
\hline \multicolumn{5}{|c|}{ B. Total inputs to Spring Creek arm of Keswick Reservoir } \\
\hline & Dissolved & 279 & $\mathrm{NC}$ & 23 \\
\hline & Colloid & $\geq 1.4$ & $\mathrm{NC}$ & $\geq 0.21$ \\
\hline & Dissolved + Colloid & $\geq 279$ & $\mathrm{NC}$ & $\geq 23$ \\
\hline & Whole Water, TR & 240 & $\mathrm{NC}$ & 29 \\
\hline \multicolumn{5}{|c|}{ C. Spring Creek arm of Keswick Reservoir } \\
\hline & Dissolved & 360 & NA & 14 \\
\hline & Colloid & 220 & NA & 25 \\
\hline & Dissolved + Colloid & 580 & $\mathrm{NC}$ & 39 \\
\hline & Whole Water, TR & 600 & NA & 32 \\
\hline \multirow[t]{5}{*}{ D. Mass balance, Spring Creek } & & & & \\
\hline & Dissolved & $77 \%$ & $\mathrm{NC}$ & $160 \%$ \\
\hline & Colloid & $0.64 \%$ & $\mathrm{NC}$ & $0.84 \%$ \\
\hline & Dissolved + Colloid & $48 \%$ & $\mathrm{NC}$ & $58 \%$ \\
\hline & Whole Water, TR & $40 \%$ & $\mathrm{NC}$ & $91 \%$ \\
\hline
\end{tabular}




\section{Appendix 4. Tables of Data Comparing Metal Loads Used in Mass Balance Calculations for Keswick Reservoir}

Table A4-1. Aluminum loads derived from concentrations in dissolved, colloid, and whole water samples used in mass balance calculations for Keswick Reservoir

Table A4-2. Cadmium loads derived from concentrations in dissolved, colloid, and whole water samples used in mass balance calculations forKeswick Reservoir

Table A4-3. Copper loads derived from concentrations in dissolved, colloid, and whole water samples used in mass balance calculations for Keswick Reservoir

Table A4-4. Iron loads derived from concentrations in dissolved, colloid, and whole water samples used in mass balance calculations for Keswick Reservoir

Table A4-5. Lead loads derived from concentrations in dissolved, colloid, and whole water samples used in mass balance calculations for Keswick Reservoir

Table A4-6. Mercury loads derived from concentrations in dissolved, colloid, and whole water samples used in mass balance calculations for Keswick Reservoir

Table A4-7. Zinc loads derived from concentrations in dissolved, colloid, and whole water samples used in mass balance calculations for Keswick Reservoir 
Table A4-1. Aluminum loads derived from concentrations in dissolved, colloid, and whole water samples used in mass balance calculations for Keswick Reservoir

[kg, kilogram; d, day; Cr., Creek; NA, not analyzed; NC, not calculated; TR, Total recoverable analysis. \%, percent; $\geq$, load is greater than or equal to value shown because colloids not analyzed from Whiskeytown Lake]

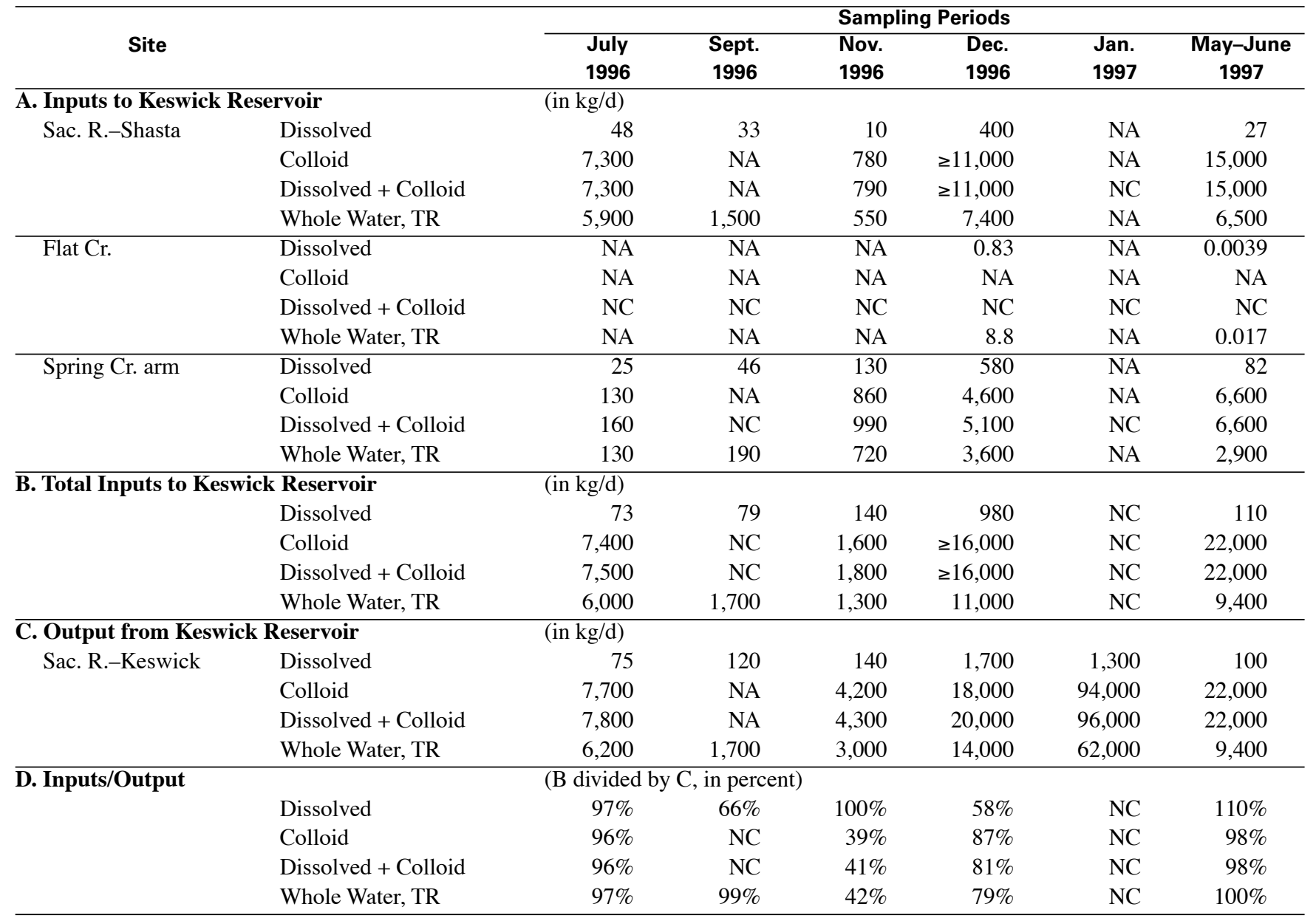


Table A4-2. Cadmium loads derived from concentrations in dissolved, colloid, and whole water samples used in mass balance calculations for Keswick Reservoir

[g, grams; d, day. Cr., Creek; R., River; Sac., Sacramento; NA, not analyzed; NC, not calculated; TR, Total recoverable analysis. $\%$, percent; $\leq$, load is less than or equal to value shown because of concentration less than detection limit; $\geq$, load is greater than or equal to value shown because colloids not analyzed from Whiskeytown Lake]

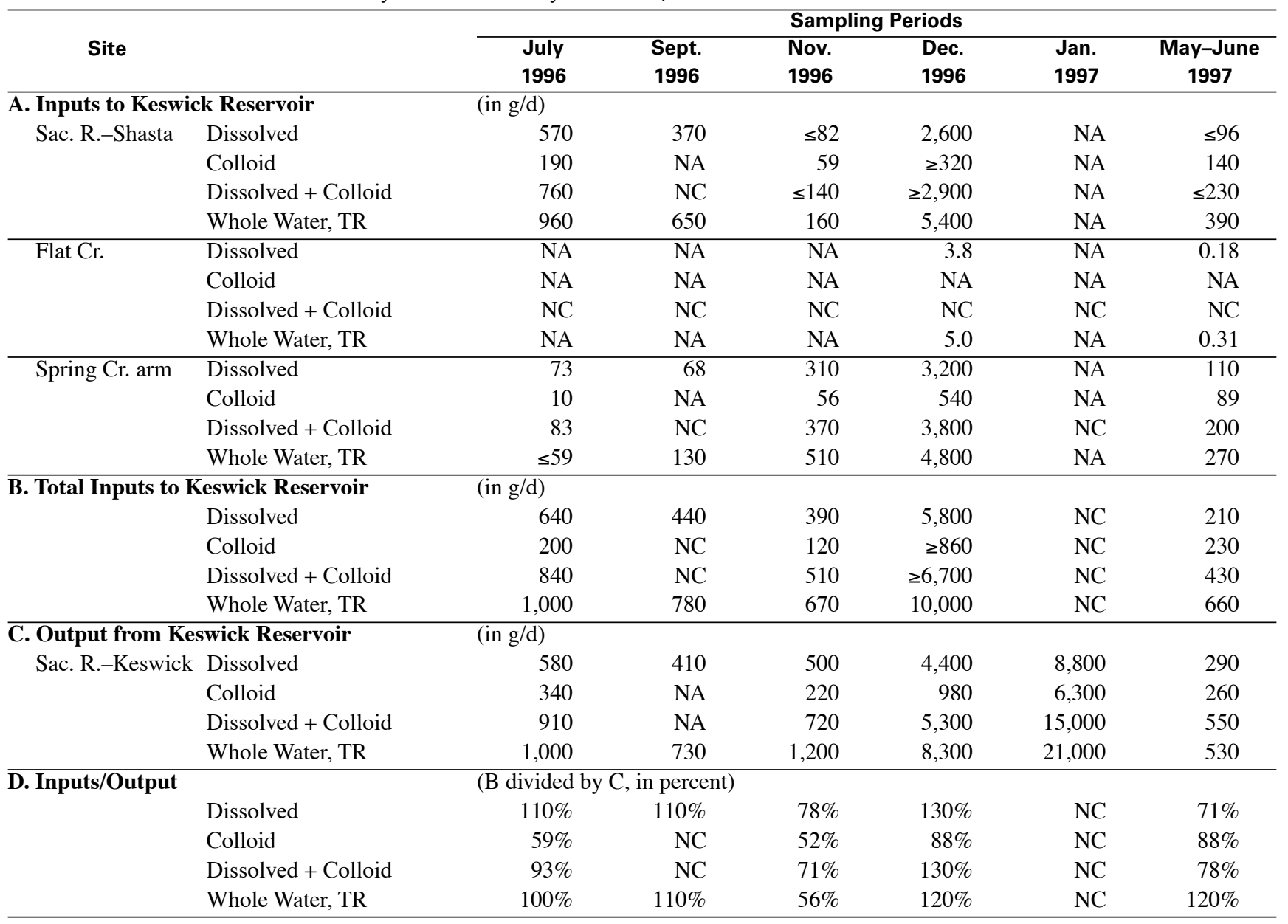


Table A4-3. Copper loads derived from concentrations in dissolved, colloid, and whole water samples used in mass balance calculations for Keswick Reservoir

[kg, kilogram; d, day; Cr., Creek; NA, not analyzed; NC, not calculated; TR, Total recoverable analysis. \%, percent; $\geq$, load is greater than or equal to value shown because colloids not analyzed from Whiskeytown Lake]

\begin{tabular}{|c|c|c|c|c|c|c|c|}
\hline \multirow{2}{*}{ Site } & & \multicolumn{6}{|c|}{ Sampling Periods } \\
\hline & & $\begin{array}{l}\text { July } \\
1996\end{array}$ & $\begin{array}{l}\text { Sept. } \\
1996\end{array}$ & $\begin{array}{l}\text { Nov. } \\
1996\end{array}$ & $\begin{array}{l}\text { Dec. } \\
1996\end{array}$ & $\begin{array}{l}\text { Jan. } \\
997\end{array}$ & $\begin{array}{c}\text { May-June } \\
1997\end{array}$ \\
\hline \multicolumn{2}{|c|}{ A. Inputs to Keswick Reservoir } & (in $\mathrm{kg} / \mathrm{d}$ ) & & & & & \\
\hline \multirow[t]{4}{*}{ Sac. R.-Shasta } & Dissolved & 30 & 10 & 4.3 & 87 & NA & 5.6 \\
\hline & Colloid & 15 & NA & 2.7 & $\geq 95$ & NA & 18 \\
\hline & Dissolved + Colloid & 44 & $\mathrm{NC}$ & 7.0 & $\geq 180$ & $\mathrm{NC}$ & 24 \\
\hline & Whole Water, TR & 55 & 27 & 14 & 320 & NA & 27 \\
\hline \multirow[t]{4}{*}{ Flat $\mathrm{Cr}$. } & Dissolved & NA & NA & NA & 0.081 & NA & 0.0016 \\
\hline & Colloid & NA & NA & NA & NA & NA & NA \\
\hline & Dissolved + Colloid & $\mathrm{NC}$ & $\mathrm{NC}$ & $\mathrm{NC}$ & $\mathrm{NC}$ & $\mathrm{NC}$ & $\mathrm{NC}$ \\
\hline & Whole Water, TR & NA & NA & NA & 0.30 & NA & 0.0063 \\
\hline \multirow[t]{4}{*}{ Spring Cr. arm } & Dissolved & 10 & 2.9 & 7.8 & 91 & NA & 3.6 \\
\hline & Colloid & 0.77 & NA & 21 & 430 & NA & 16 \\
\hline & Dissolved + Colloid & 10 & NA & 28 & 520 & $\mathrm{NC}$ & 20 \\
\hline & Whole Water, TR & 5.6 & 8.9 & 40 & 480 & NA & 22 \\
\hline \multicolumn{2}{|c|}{ B. Total Inputs to Keswick Reservoir } & (in $\mathrm{kg} / \mathrm{d})$ & & & & & \\
\hline & Dissolved & 40 & 13 & 12 & 180 & $\mathrm{NC}$ & 9 \\
\hline & Colloid & 16 & NA & 24 & $\geq 530$ & $\mathrm{NC}$ & 34 \\
\hline & Dissolved + Colloid & 54 & NA & 35 & $\geq 700$ & $\mathrm{NC}$ & 44 \\
\hline & Whole Water, TR & 61 & 36 & 54 & 800 & $\mathrm{NC}$ & 49 \\
\hline \multicolumn{2}{|c|}{ C. Output from Keswick Reservoir } & (in $\mathrm{kg} / \mathrm{d})$ & & & & & \\
\hline \multirow[t]{4}{*}{ Sac. R.-Keswick } & Dissolved & 29 & 12 & 9.2 & 130 & 260 & 14 \\
\hline & Colloid & 15 & NA & 22 & 180 & 1,000 & 31 \\
\hline & Dissolved + Colloid & 43 & $\mathrm{NC}$ & 31 & 310 & 1,300 & 45 \\
\hline & Whole Water, TR & 56 & 40 & 56 & 670 & 1,400 & 48 \\
\hline \multirow[t]{5}{*}{ D. Inputs/Output } & & (B divided 1 & n percen & & & & \\
\hline & Dissolved & $140 \%$ & $110 \%$ & $130 \%$ & $140 \%$ & $\mathrm{NC}$ & $66 \%$ \\
\hline & Colloid & $110 \%$ & $\mathrm{NC}$ & $110 \%$ & $290 \%$ & $\mathrm{NC}$ & $110 \%$ \\
\hline & Dissolved + Colloid & $130 \%$ & $\mathrm{NC}$ & $110 \%$ & $230 \%$ & $\mathrm{NC}$ & $98 \%$ \\
\hline & Whole Water, TR & $110 \%$ & $90 \%$ & $100 \%$ & $120 \%$ & $\mathrm{NC}$ & $100 \%$ \\
\hline
\end{tabular}


Table A4-4. Iron loads derived from concentrations in dissolved, colloid, and whole water samples used in mass balance calculations for Keswick Reservoir

[kg, kilogram; d, day. Cr., Creek; R., River; Sac., Sacramento; NA, not analyzed; NC, not calculated; TR, Total recoverable analysis. $\%$, percent; $\leq$, load is less than or equal to value shown because of concentration less than detection limit; $\geq$, load is greater than or equal to value shown because colloids not analyzed from Whiskeytown Lake]

\begin{tabular}{|c|c|c|c|c|c|c|c|}
\hline \multirow[b]{2}{*}{ Site } & & \multicolumn{6}{|c|}{ Sampling Periods } \\
\hline & & $\begin{array}{l}\text { July } \\
1996\end{array}$ & $\begin{array}{l}\text { Sept. } \\
1996\end{array}$ & $\begin{array}{l}\text { Nov. } \\
1996\end{array}$ & $\begin{array}{l}\text { Dec. } \\
1996\end{array}$ & $\begin{array}{l}\text { Jan. } \\
997\end{array}$ & $\begin{array}{c}\text { May-June } \\
1997\end{array}$ \\
\hline \multicolumn{2}{|c|}{ A. Inputs to Keswick Reservoir } & (in $\mathrm{kg} / \mathrm{d}$ ) & & & & & \\
\hline \multirow{4}{*}{ Sac. R.-Shasta } & Dissolved & $\leq 270$ & 93 & 21 & 220 & NA & 41 \\
\hline & Colloid & 4,900 & NA & 490 & $\geq 6,300$ & NA & 9,100 \\
\hline & Dissolved + Colloid & $\leq 5,100$ & NA & 510 & $\geq 6,500$ & $\mathrm{NC}$ & 9,200 \\
\hline & Whole Water, TR & 4,100 & 930 & 490 & 6,400 & NA & 5,500 \\
\hline \multirow[t]{4}{*}{ Flat $\mathrm{Cr}$. } & Dissolved & NA & NA & NA & 0.10 & NA & 0.30 \\
\hline & Colloid & NA & NA & NA & NA & NA & NA \\
\hline & Dissolved + Colloid & $\mathrm{NC}$ & $\mathrm{NC}$ & $\mathrm{NC}$ & $\mathrm{NC}$ & $\mathrm{NC}$ & $\mathrm{NC}$ \\
\hline & Whole Water, TR & NA & NA & NA & 6.2 & NA & 1.2 \\
\hline \multirow[t]{4}{*}{ Spring Cr. arm } & Dissolved & 10 & 19 & 13 & 71 & NA & 31 \\
\hline & Colloid & 140 & NA & 820 & 3,300 & NA & 6,600 \\
\hline & Dissolved + Colloid & 150 & $\mathrm{NC}$ & 830 & 3,300 & $\mathrm{NC}$ & 6,700 \\
\hline & Whole Water, TR & $\leq 200$ & $\leq 280$ & 760 & 2,000 & NA & 3,700 \\
\hline \multicolumn{2}{|c|}{ B. Total Inputs to Keswick Reservoir } & (in $\mathrm{kg} / \mathrm{d}$ ) & & & & & \\
\hline & Dissolved & 280 & 110 & 34 & 300 & $\mathrm{NC}$ & 72 \\
\hline & Colloid & 5,000 & $\mathrm{NC}$ & 1,300 & $\geq 9,600$ & $\mathrm{NC}$ & 16,000 \\
\hline & Dissolved + Colloid & 5,300 & $\mathrm{NC}$ & 1,300 & $\geq 9,800$ & $\mathrm{NC}$ & 16,000 \\
\hline & Whole Water, TR & 4,300 & 1,200 & 1,300 & 8,400 & $\mathrm{NC}$ & 9,200 \\
\hline \multicolumn{2}{|c|}{ C. Output from Keswick Reservoir } & (in $\mathrm{kg} / \mathrm{d}$ & & & & & \\
\hline \multirow[t]{4}{*}{ Sac. R.-Keswick } & Dissolved & 77 & 45 & 27 & 230 & 550 & 70 \\
\hline & Colloid & 4,600 & NA & 3,600 & 13,000 & 110,000 & 16,000 \\
\hline & Dissolved + Colloid & 4,700 & NA & 3,600 & 14,000 & 110,000 & 16,000 \\
\hline & Whole Water, TR & 4,200 & 1,200 & 3,200 & 14,000 & 84,000 & 9,400 \\
\hline \multirow[t]{5}{*}{ D. Inputs/Output } & & (B divided $\mathrm{l}$ & n percen & & & & \\
\hline & Dissolved & $360 \%$ & $250 \%$ & $130 \%$ & $130 \%$ & $\mathrm{NC}$ & $100 \%$ \\
\hline & Colloid & $110 \%$ & $\mathrm{NC}$ & $36 \%$ & $74 \%$ & $\mathrm{NC}$ & $98 \%$ \\
\hline & Dissolved + Colloid & $110 \%$ & $\mathrm{NC}$ & $37 \%$ & $70 \%$ & $\mathrm{NC}$ & $99 \%$ \\
\hline & Whole Water, TR & $100 \%$ & $100 \%$ & $39 \%$ & $60 \%$ & $\mathrm{NC}$ & $98 \%$ \\
\hline
\end{tabular}


Table A4-5. Lead loads derived from concentrations in dissolved, colloid, and whole water samples used in mass balance calculations for Keswick Reservoir

[kg, kilogram; d, day. Cr., Creek; R., River; Sac., Sacramento; NA, not analyzed; NC, not calculated; TR, Total recoverable analysis. $\%$, percent; $\leq$, load is less than or equal to value shown because of concentration less than detection limit; $\geq$, load is greater than or equal to value shown because colloids not analyzed from Whiskeytown Lake]

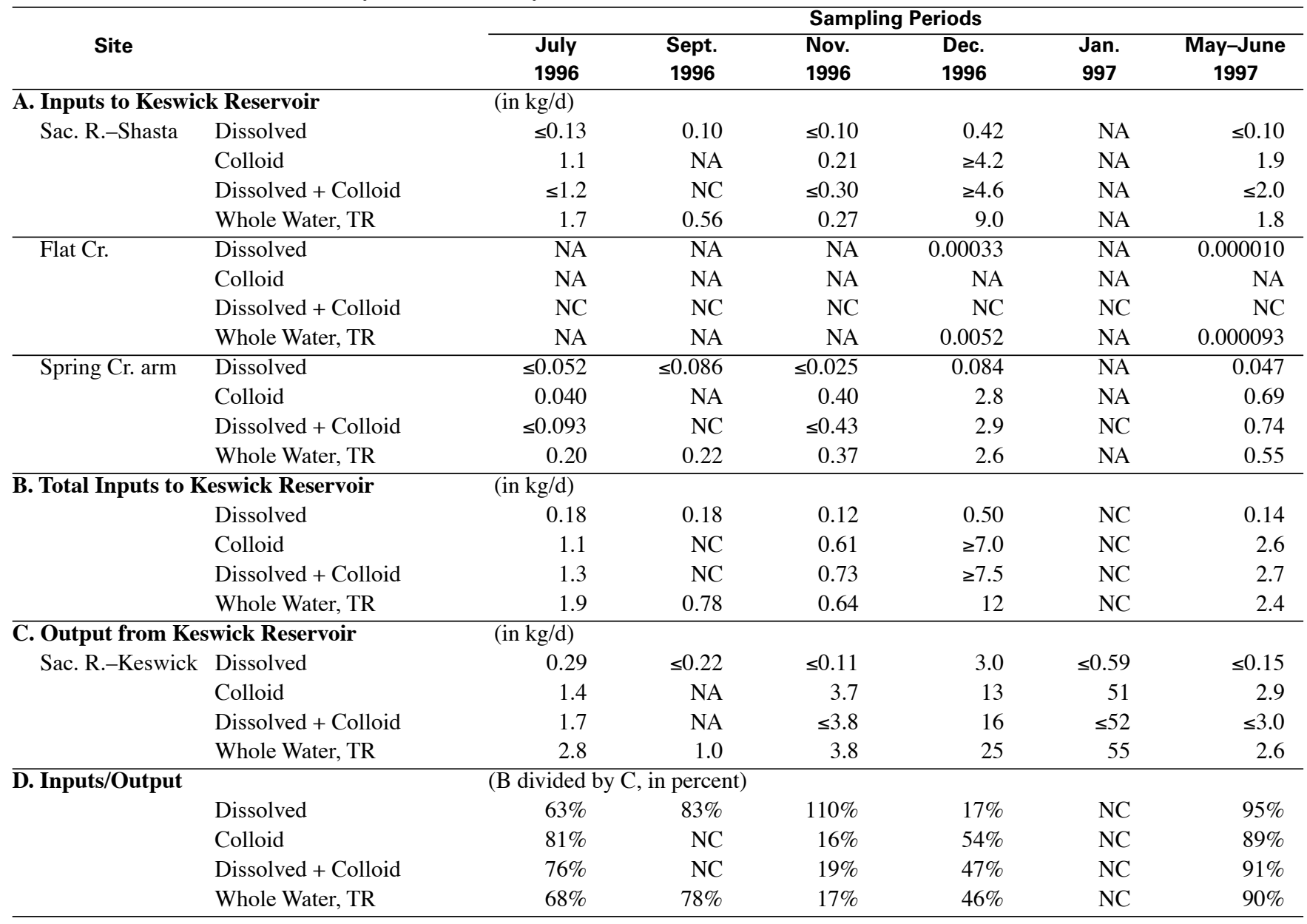


Table A4-6. Mercury loads derived from concentrations in dissolved, colloid, and whole water samples used in mass balance calculations for Keswick Reservoir

[g, grams; d, day. Cr., Creek; R., River; Sac., Sacramento; NA, not analyzed; NC, not calculated; TR, Total recoverable analysis. $\%$, percent; $\leq$, load is less than or equal to value shown because of concentration less than detection limit; $\geq$, load is greater than or equal to value shown because colloids not analyzed from Whiskeytown Lake]

\begin{tabular}{|c|c|c|c|c|c|c|c|}
\hline \multirow{2}{*}{\multicolumn{2}{|c|}{ Site }} & \multicolumn{6}{|c|}{ Sampling Periods } \\
\hline & & July & Sept. & Nov. & Dec. & Jan. & May-June \\
\hline \multicolumn{2}{|c|}{ A. Inputs to Keswick Reservoir } & (in $\mathrm{g} / \mathrm{d}$ ) & & & & & \\
\hline \multirow[t]{4}{*}{ Sac. R.-Shasta } & Dissolved & 27 & $\leq 9.7$ & 6.3 & 85 & NA & 19 \\
\hline & Colloid & 16 & NA & 4.1 & $\geq 67$ & NA & 24 \\
\hline & Dissolved + Colloid & 43 & $\mathrm{NC}$ & 10 & $\geq 150$ & $\mathrm{NC}$ & 43 \\
\hline & Whole Water, TR & 24 & $\leq 6.8$ & 9.5 & 67 & NA & 38 \\
\hline \multirow[t]{4}{*}{ Flat Cr. } & Dissolved & NA & NA & NA & 0.029 & NA & 0.0036 \\
\hline & Colloid & NA & NA & NA & NA & NA & NA \\
\hline & Dissolved + Colloid & $\mathrm{NC}$ & $\mathrm{NC}$ & $\mathrm{NC}$ & $\mathrm{NC}$ & $\mathrm{NC}$ & $\mathrm{NC}$ \\
\hline & Whole Water, TR & NA & NA & NA & 0.090 & NA & 0.0069 \\
\hline \multirow[t]{4}{*}{ Spring Cr. arm } & Dissolved & 5.7 & $\leq 3.1$ & 2.8 & $\leq 4.6$ & NA & 16 \\
\hline & Colloid & 1.7 & NA & 4.2 & 44 & NA & 19 \\
\hline & Dissolved + Colloid & 7.4 & $\mathrm{NC}$ & 7.0 & $\leq 49$ & $\mathrm{NC}$ & 34 \\
\hline & Whole Water, TR & 7.7 & 5.5 & 4.1 & 33 & NA & 27 \\
\hline \multicolumn{2}{|c|}{ B. Total Inputs to Keswick Reservoir } & (in $\mathrm{g} / \mathrm{d}$ ) & & & & & \\
\hline & Dissolved & 33 & 13 & 9.1 & 90 & $\mathrm{NC}$ & 35 \\
\hline & Colloid & 18 & $\mathrm{NC}$ & 8.3 & $\geq 110$ & $\mathrm{NC}$ & 43 \\
\hline & Dissolved + Colloid & 50 & $\mathrm{NC}$ & 17 & $\geq 200$ & $\mathrm{NC}$ & 77 \\
\hline & Whole Water, TR & 32 & 12 & 14 & 100 & $\mathrm{NC}$ & 65 \\
\hline \multicolumn{2}{|c|}{ C. Output from Keswick Reservoir } & (in $\mathrm{g} / \mathrm{d}$ ) & & & & & \\
\hline \multirow[t]{4}{*}{ Sac. R..-Keswick } & Dissolved & 33 & $\leq 8.1$ & 14 & 75 & $\leq 32$ & 18 \\
\hline & Colloid & 26 & NA & 21 & 160 & 810 & 53 \\
\hline & Dissolved + Colloid & 59 & NA & 35 & 230 & $\leq 840$ & 71 \\
\hline & Whole Water, TR & 41 & 18 & 30 & 140 & 810 & 88 \\
\hline \multirow[t]{5}{*}{ D. Inputs/Output } & & (B divided $\mathrm{b}$ ) & ( percent) & & & & \\
\hline & Dissolved & $99 \%$ & $160 \%$ & $65 \%$ & $120 \%$ & $\mathrm{NC}$ & $190 \%$ \\
\hline & Colloid & $68 \%$ & $\mathrm{NC}$ & $40 \%$ & $69 \%$ & $\mathrm{NC}$ & $81 \%$ \\
\hline & Dissolved + Colloid & $85 \%$ & $\mathrm{NC}$ & $49 \%$ & $87 \%$ & $\mathrm{NC}$ & $110 \%$ \\
\hline & Whole Water, TR & $77 \%$ & $68 \%$ & $45 \%$ & $71 \%$ & $\mathrm{NC}$ & $74 \%$ \\
\hline
\end{tabular}


Table A4-7. Zinc loads derived from concentrations in dissolved, colloid, and whole water samples used in mass balance calculations for Keswick Reservoir

[kg, kilogram; d, day. Cr., Creek; NA, not analyzed; NC, not calculated; R., River; Sac., Sacramento; TR, Total recoverable analysis. $\%$, percent; $\geq$, load is greater than or equal to value shown because colloids not analyzed from Whiskeytown Lake]

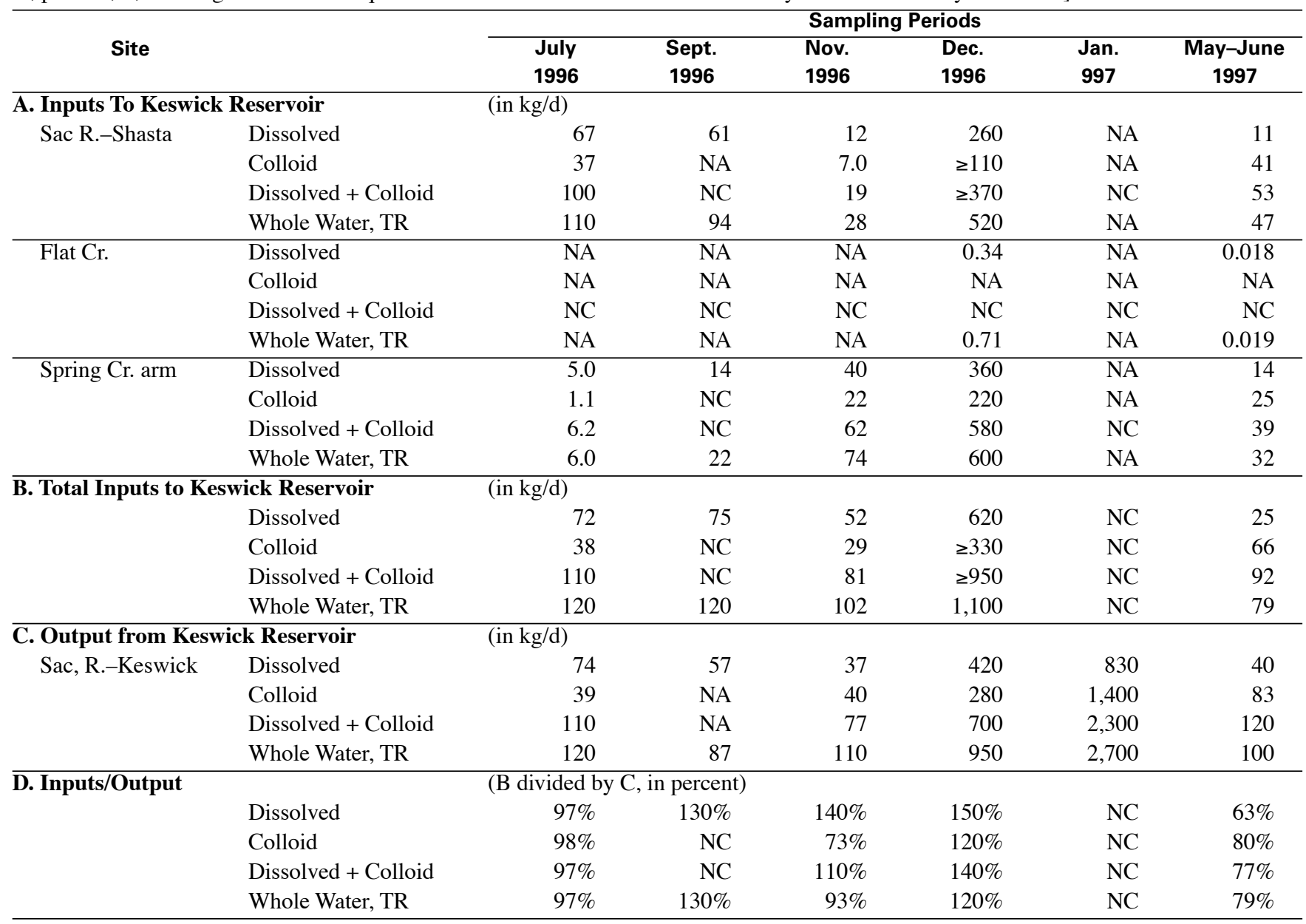


Appendix 5. Plots of Metal Loads in Dissolved and Colloidal Forms for Miscellaneous Trace Metals in Water

Figure A5-1. Plot of dissolved and colloidal chromium loads, July 1996 to May-June (labeled as May on graph) 1997, Sacramento River, California.

Figure A5-2. Plot of dissolved and colloidal cobalt loads, July 1996 to May-June (labeled as May on graph) 1997, Sacramento River, California.

Figure A5-3. Plot of dissolved and colloidal nickel loads, July 1996 to May-June (labeled as May on graph) 1997, Sacramento River, California.

Figure A5-4. Plot of dissolved and colloidal yttrium loads, July 1996 to May-June (labeled as May on graph) 1997, Sacramento River, California. 


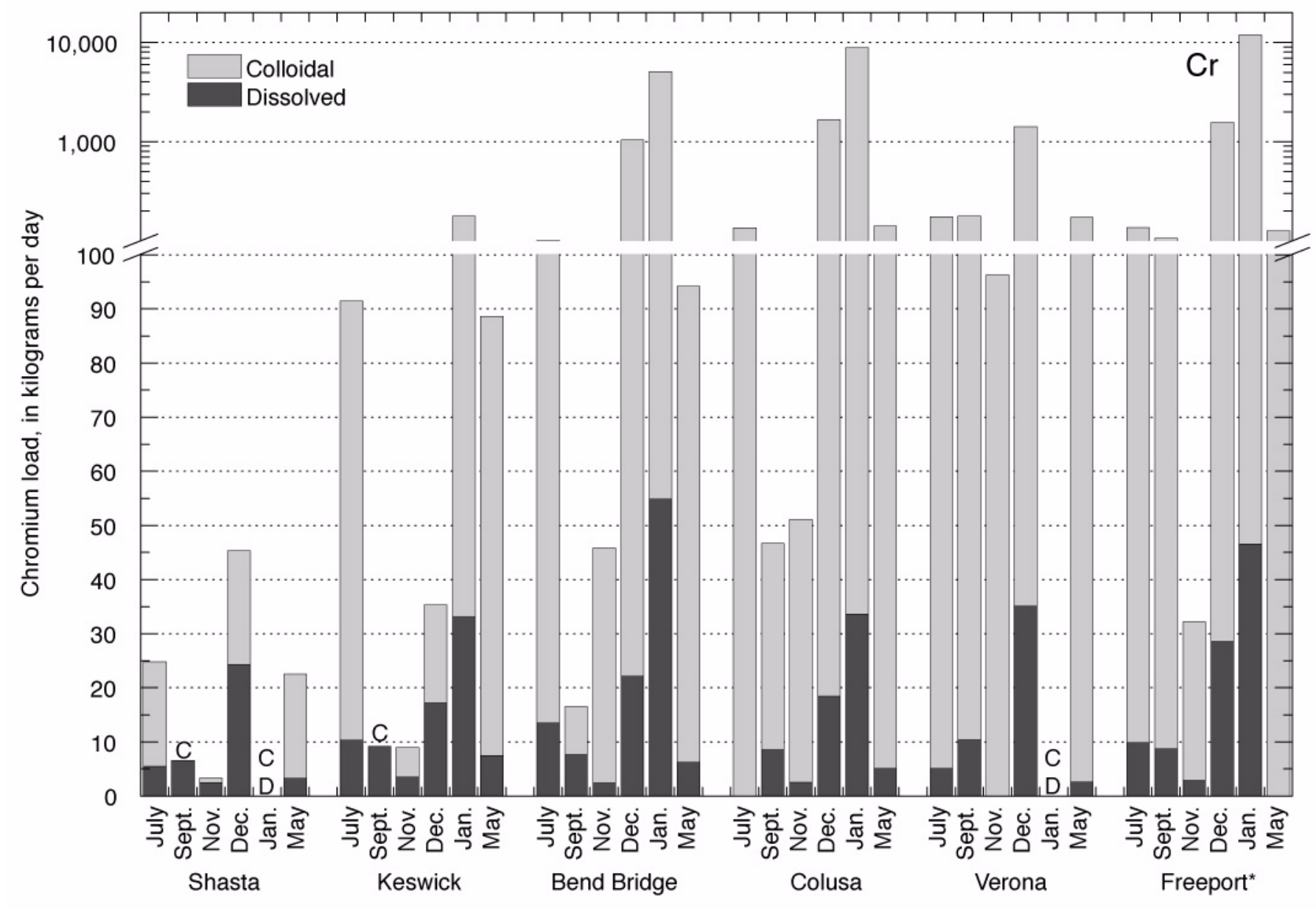

Figure A5-1. Plot of dissolved and colloidal chromium (Cr) loads, July 1996 to May-June (labeled as May on graph) 1997, Sacramento River, California. C, no colloidal load data available; D, no dissolved load data available. Freeport data for January 1997 is the sum of loads from the Sacramento River at Tower Bridge plus the Yolo Bypass. 


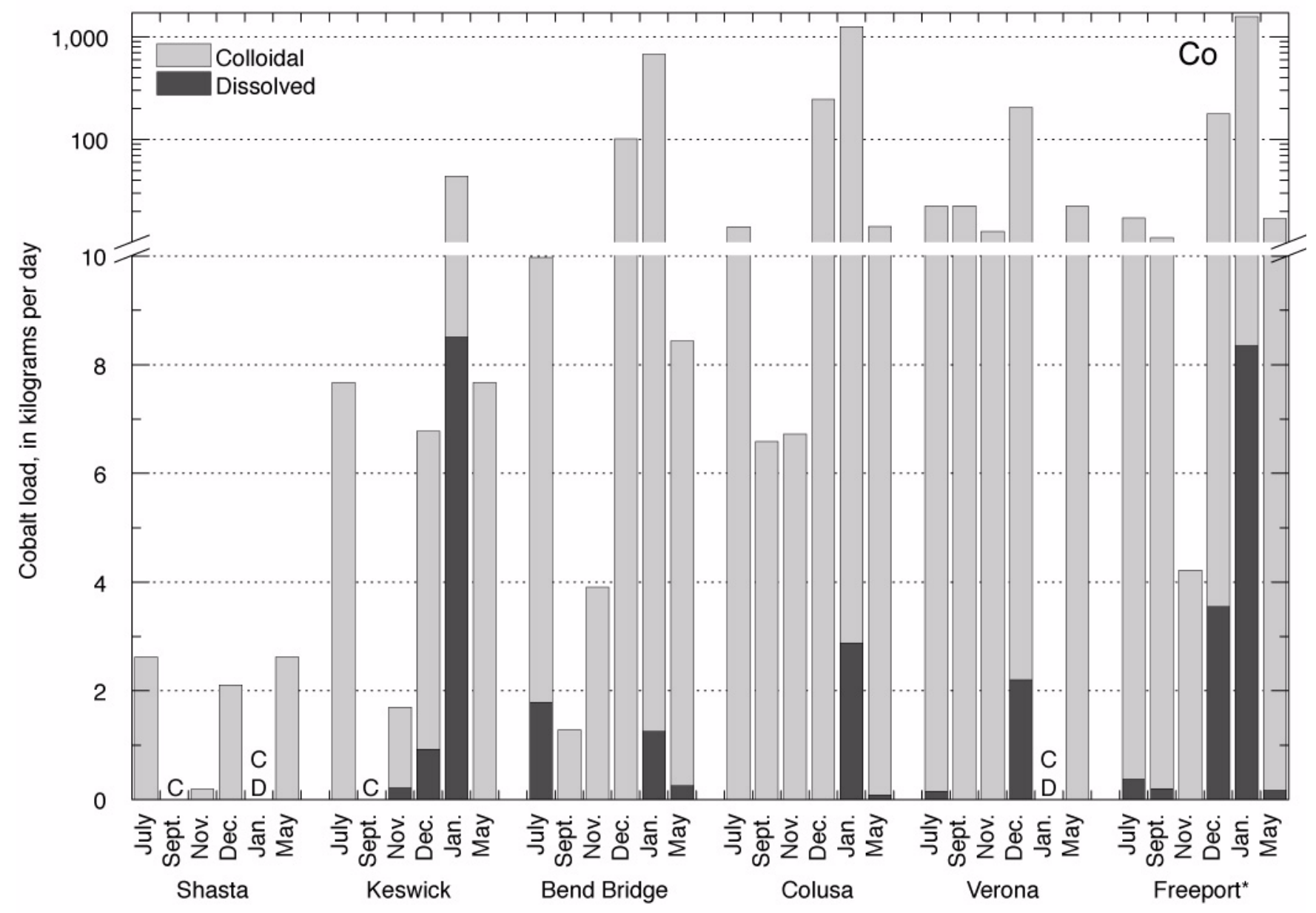

Figure A5-2. Plot of dissolved and colloidal cobalt (Co) loads, July 1996 to May-June (labeled as May on graph) 1997, Sacramento River, California. C, no colloidal load data available; D, no dissolved load data available. Freeport data for January 1997 is the sum of loads from the Sacramento River at Tower Bridge plus the Yolo Bypass. 


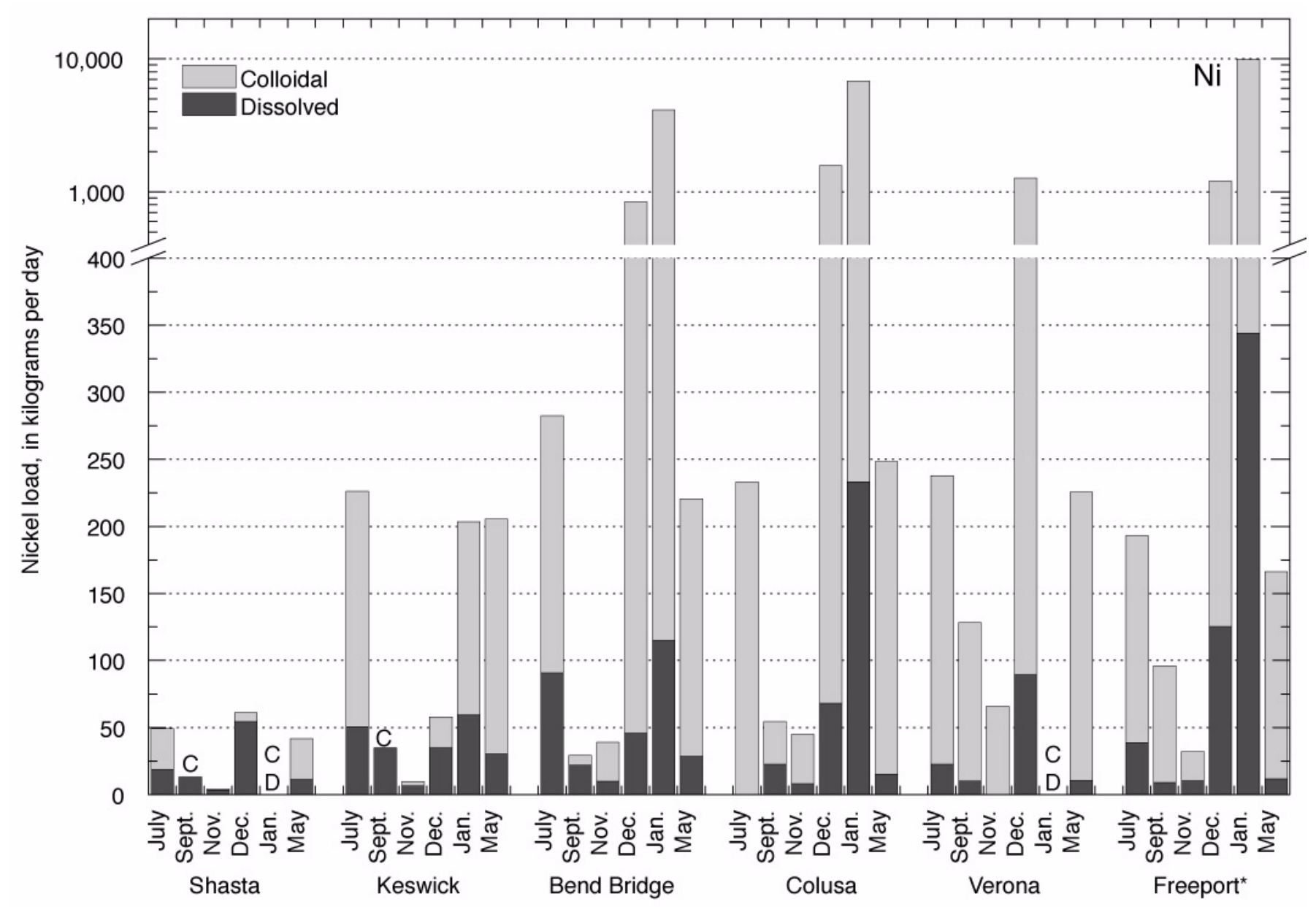

Figure A5-3. Plot of dissolved and colloidal nickel (Ni) loads, July 1996 to May-June (labeled as May on graph) 1997, Sacramento River, Californ C, no colloidal load data available; D, no dissolved load data available. Freeport data for January 1997 is the sum of loads from the Sacramen River at Tower Bridge plus the Yolo Bypass.

100 Metals Transport in the Sacramento River, California, 1996-1997. Volume 2: Interpretation of Metal Loads 


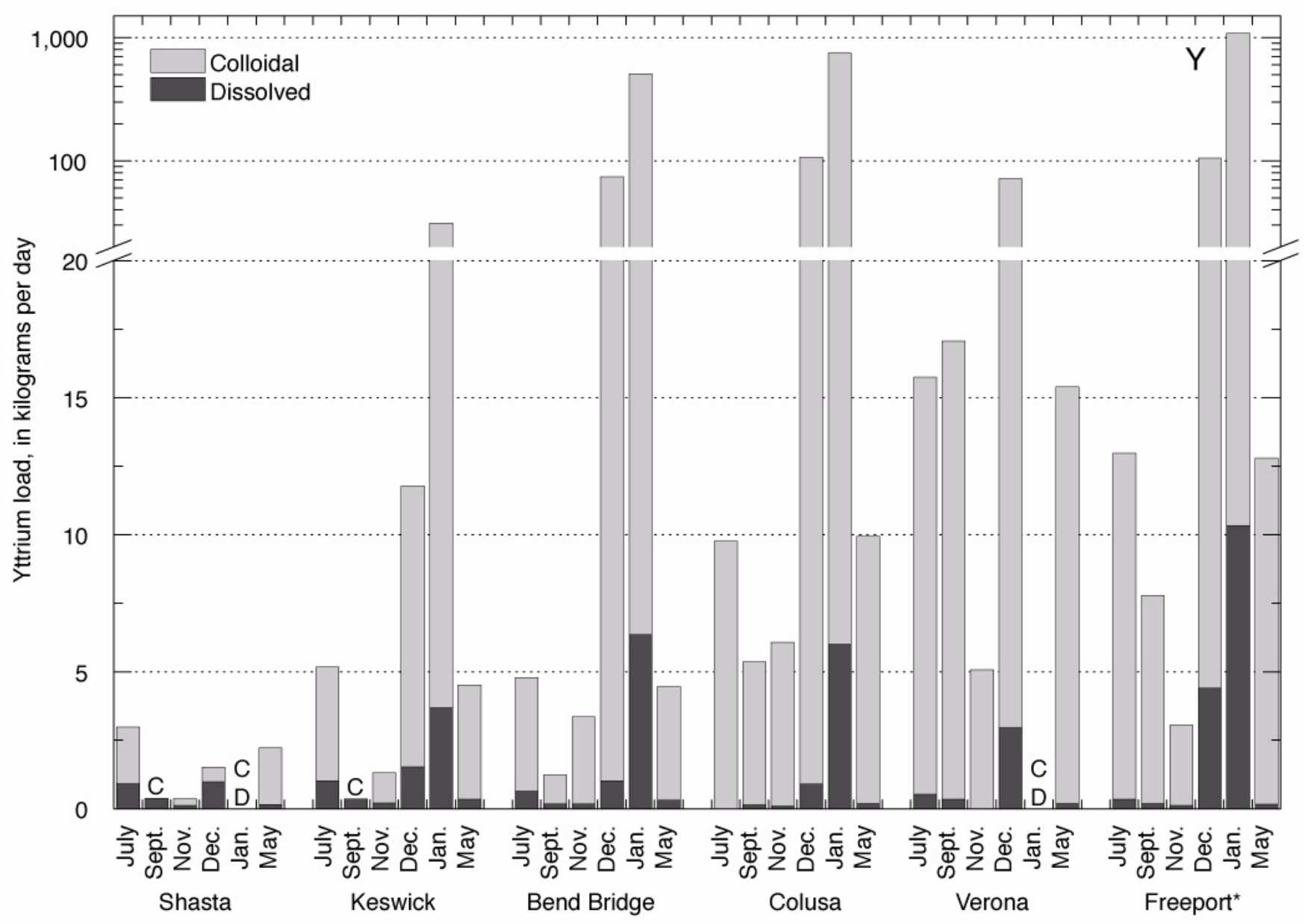

Figure A5-4. Plot of dissolved and colloidal yttrium (Y) loads, July 1996 to May-June (labeled as May on graph) 1997, Sacramento River, California. C, no colloidal load data available; D, no dissolved load data available. Freeport data for January 1997 is the sum of loads from the Sacramento River at Tower Bridge plus the Yolo Bypass. 



\section{Appendix 6. Hydrographs Showing Daily Mean Discharge and Time of Sampling}

Figure A6-1. Hydrographs showing daily mean discharge and time of sampling, November 1996, Sacramento River, California for A. Below Keswick Dam, B. Bend Bridge, C. Colusa, D. Yolo Bypass, $E$. Verona, and F. Freeport.

Figure A6-2. Hydrographs showing daily mean discharge and time of sampling, December 1996, Sacramento River, California for A. Below Keswick Dam, B. Bend Bridge, C. Colusa, D. Yolo Bypass, $E$. Verona, and F. Freeport.

Figure A6-3. Hydrographs showing daily mean discharge and time of sampling, January 1997, Sacramento River, California for A. Below Keswick Dam, B. Bend Bridge, C. Colusa, D. Yolo Bypass, $E$. Verona, and $F$. Freeport. 

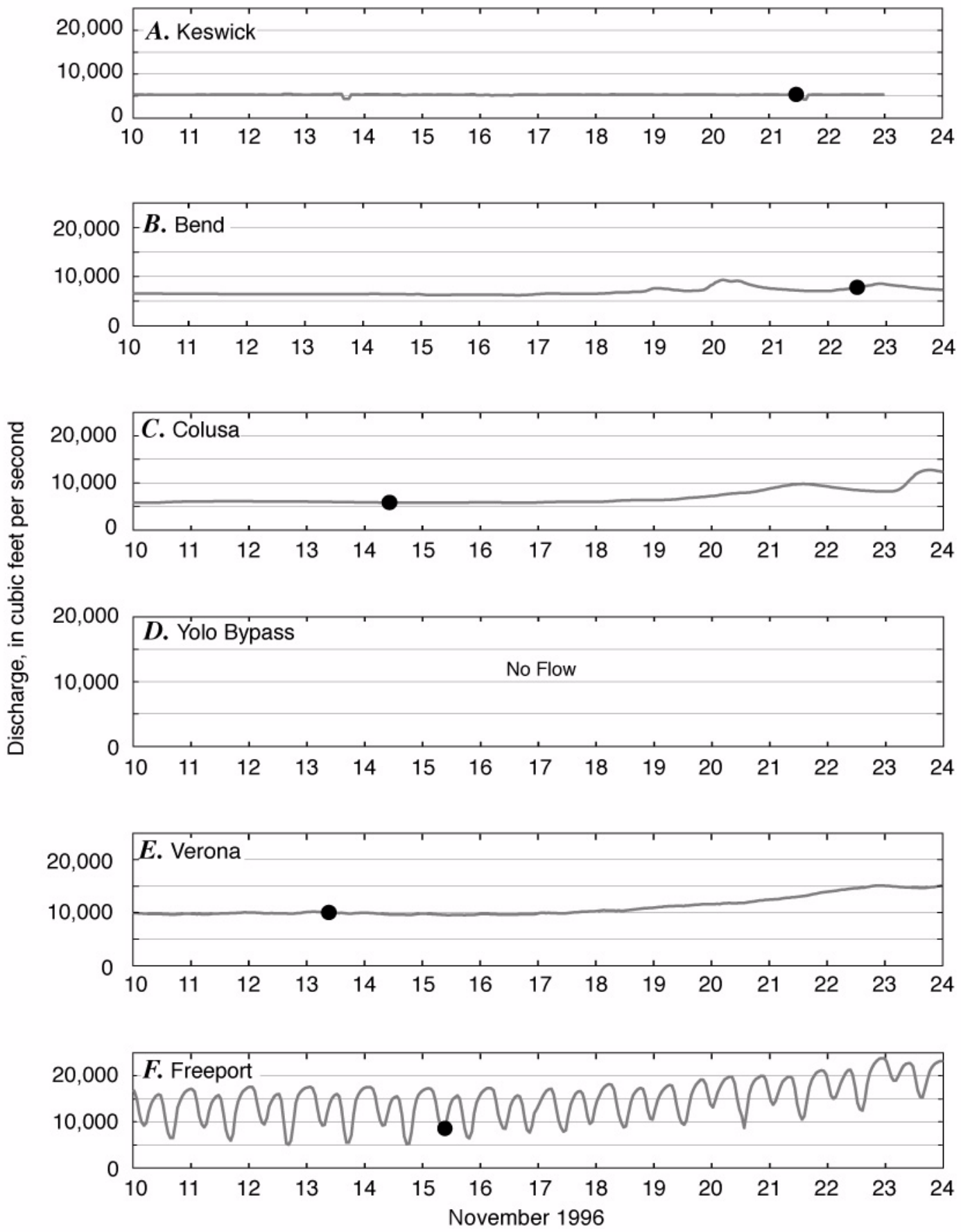

Figure A6-1. Hydrographs showing daily mean discharge and time of sampling, November 1996, Sacramento River, California for $A$. Below Keswick Dam, B. Bend Bridge, C. Colusa, D. Yolo Bypass, E. Verona, and F. Freeport. 

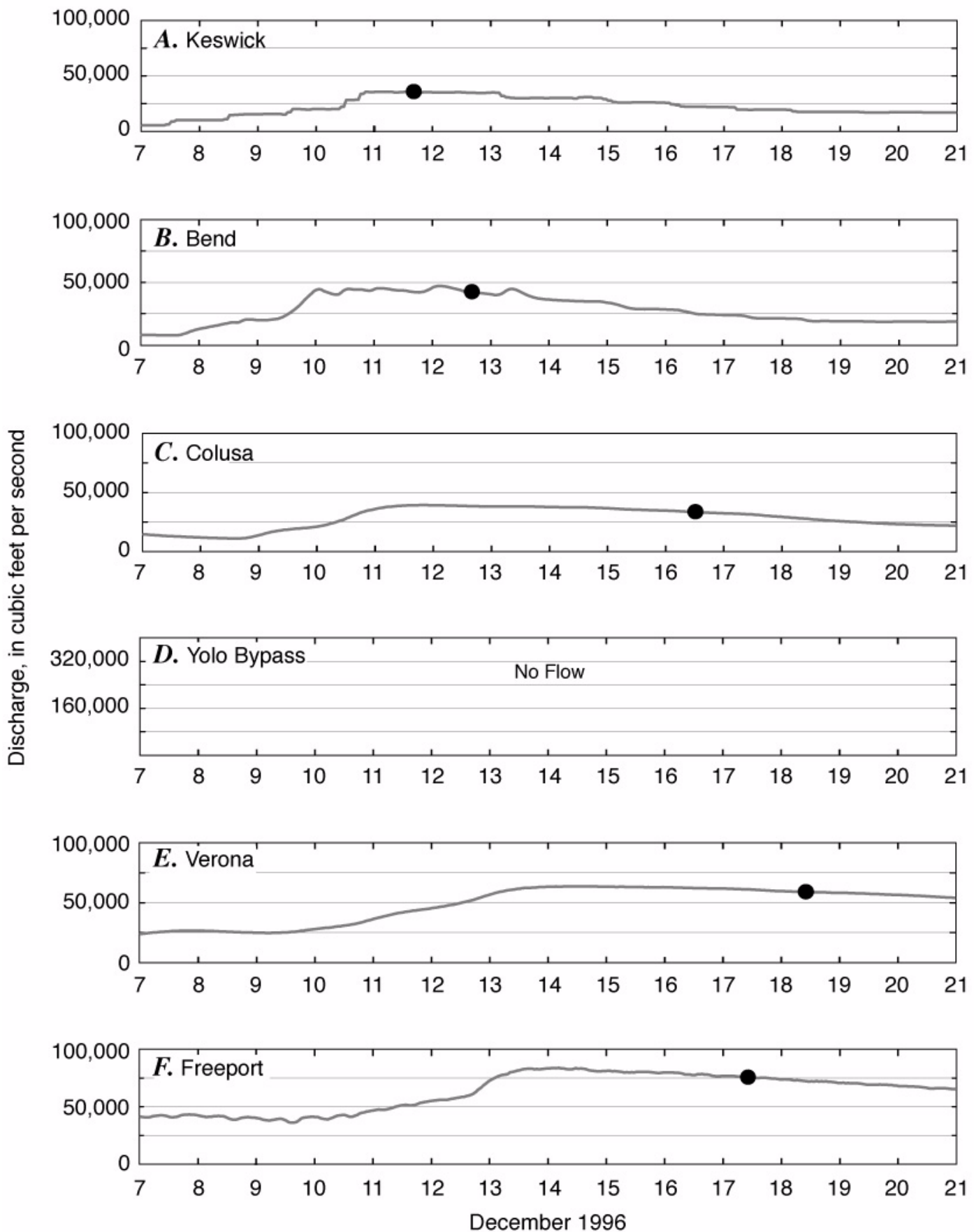

Figure A6-2. Hydrographs showing daily mean discharge and time of sampling, December 1996, Sacramento River, California for $A$. Below Keswick Dam, $B$. Bend Bridge, $C$. Colusa, $D$. Yolo Bypass, E. Verona, and F. Freeport. 

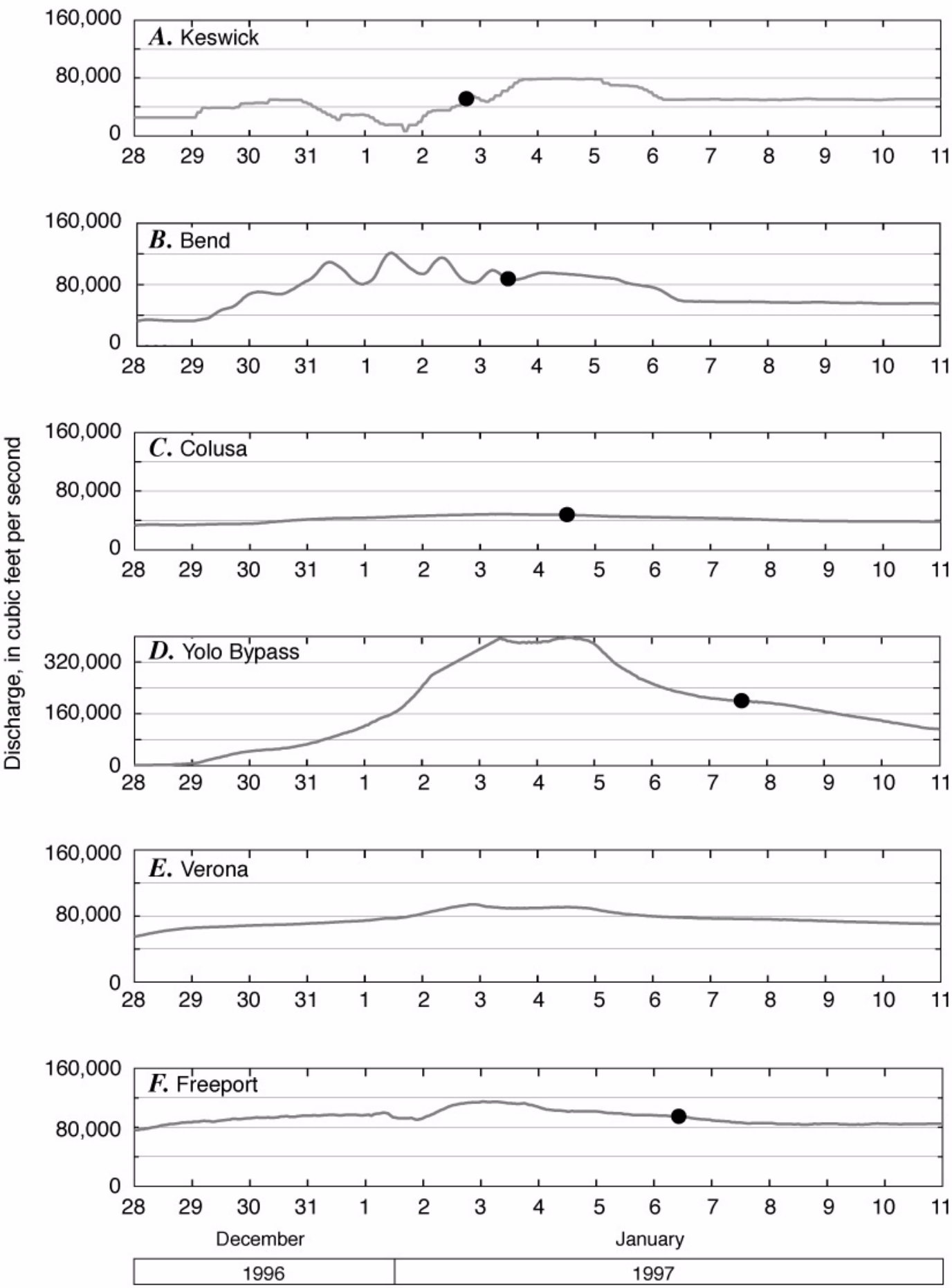

Figure A6-3. Hydrographs showing daily mean discharge and time of sampling, January 1997, Sacramento River, California for $A$. Below Keswick Dam, B. Bend Bridge, C. Colusa, D. Yolo Bypass, E. Verona, and F. Freeport. 